UNIVERSIDADE DE SÃO PAULO

INSTITUTO DE FÍSICA DE SÃO CARLOS

\title{
PRODUÇÃO E CARACTERIZAÇÃO DE FILMES FINOS DE SILÍCIO AMORFO HIDROGENADO POR DESCARGA LUMINESCENTE A $60 \mathrm{~Hz}$
}

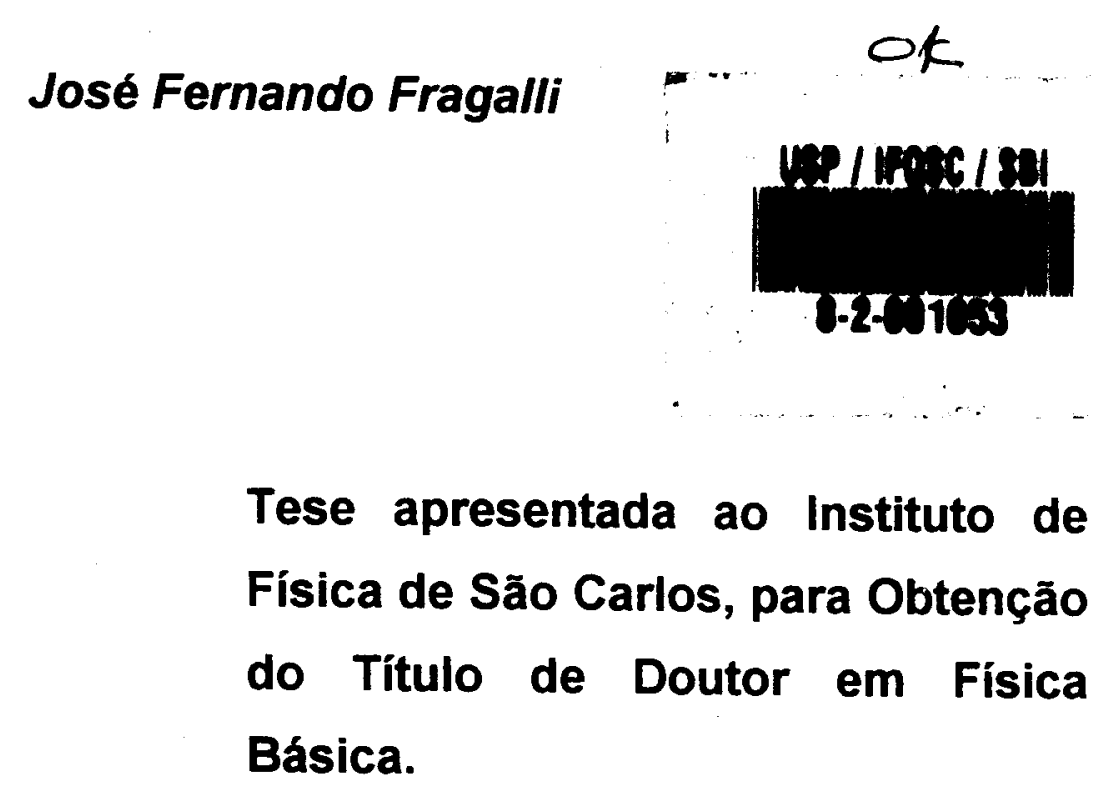
Física de São Carlos, para Obtenção do Título de Doutor em Física Básica.

Orientador: Prof. Dr. Vanderlei Salvador Bagnato

Departamento de Física e Ciência dos Materiais São Carlos - 1994 


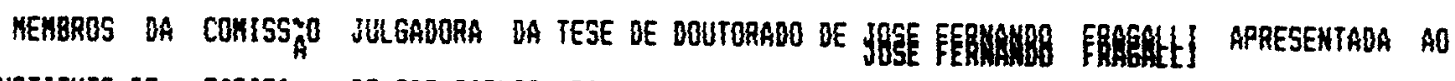

iKSTITUTO DE FISICA DE SAO CARLOS. DA UHIUERSIOADE DE SRO PAULO. EN 28/10/1994

COMISSAO JULGAOAA:
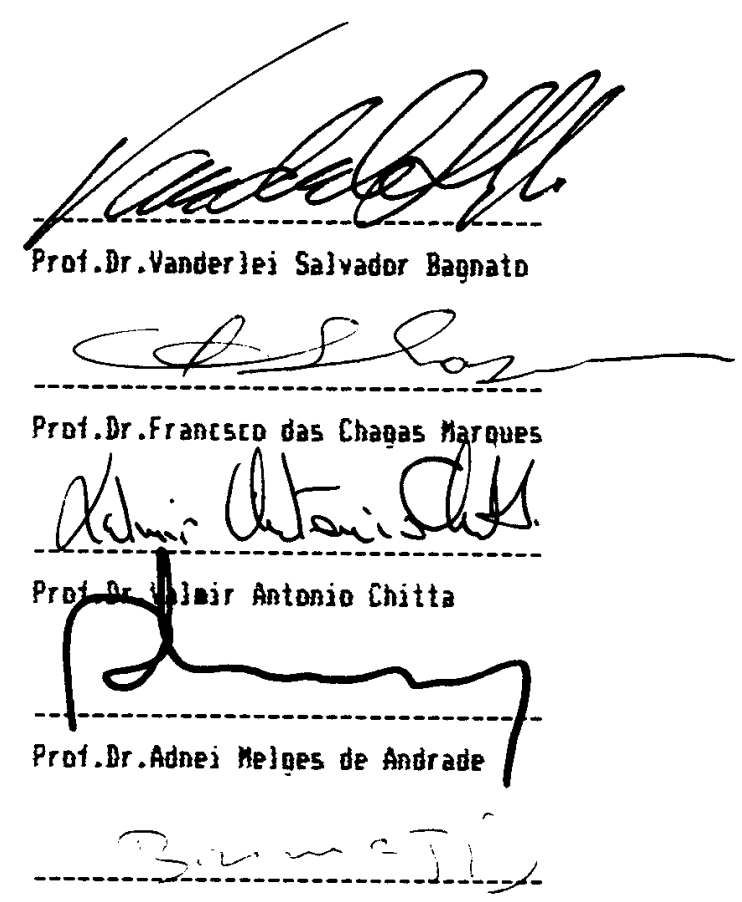

Proi.Dr.Pjerre Basajij 
Ao meu pai Vicentino (in memorian), à minha mãe Aurora, aos meus irmãos, e aos meus amores Carmen Lucia e Rafael. 


\section{AGRADECIMENTOS}

Ao meu orientador, Prof. Dr. Vanderlei Bagnato, por todo apoio e amizade dedicados ao longo de todo o trabalho.

Ao sempre amigo e companheiro Lino, sem o qual este trabalho não teria chegado ao fim. Não existem palavras para agradecer sua dedicação e amizade.

Aos companheiros de sala, em especial ao Gustavo e ao Norio, pela presença nos momentos de descontração e estudo.

Aos colegas e professores do Grupo de Óptica pelo apoio recebido.

To my american fellows, Greg Horner and Bob Backes.

To my "american family", Jim Bernard, Sarah Kurtz and little Benjamin for the friendship along the six monhs I lived at Golden.

To my NREL fellows, specially Dick Crandall, Simon Tsuo, Howard Branz, and Mellody, for the support along my stage at NREL.

Aos pesquisadores lituanos Vytas Grivickas e Jonas Kolenda pelo muito aprendido durante a permanência deles no IFSC-USP.

Aos meus colegas do Departamento de Física da UNESP-Bauru, especialmente ao Prof. Humberto Silva e Prof. Carlos Fonzar pela amizade ao longo do ano e meio convivido naquela instituição.

À minha cara amiga Rita David, pela convivência nas viagens semanais até Bauru.

Aos novos colegas do Departamento de Fisica da UDESC-Joinville, pelo apoio crucial nos últimos meses deste trabalho.

$E$, at last, but not least, à minha esposa Carmen Lucia, e ao meu filho Rafael, pela compreensão nos inúmeros momentos em que, pela força do trabalho, eu tive que estar ausente. 


\section{ÍNDICE}

LISTA DE FIGURAS

iv

LISTA DE TABELA

$\mathbf{x}$

RESUMO

$\mathbf{x i}$

ABSTRACT

xii

SEÇÃO 1 - INTRODUÇÃO

1

SEÇÃO 2 - PRODUÇÃO DE FILMES AMORFOS PELA TÉCNICA

DE

DESCARGA

\section{LUMINESCENTE}

4

2.1. Um pouco de História

2.2. Medidas de Diagnóstico

2.3. Mecanismos Envolvidos na Deposição de aSi:H

8

SEÇÃO 3 - CONSTRUÇÃO DE UM REATOR DE DESCARGA LUMINESCENTE A BAIXAS FREQUÊNCIAS

3.1. Introdução

3.2. O Projeto de um Sistema de Deposição

3.2.1. A Geometria dos Eletrodos

3.2.2. Tensão de Polarização de Controle

3.2.3. O Confinamento do Plasma

3.2.4. Contaminação a Partir de Impurezas 
3.3. Os Parâmetros de Deposição 20

3.3.1. Densidade de Potência RF 20

3.3.2. Temperatura do Substrato 22

3.3.3. A Concentração dos Gases 23

3.3.4. Pressão de Deposição 24

3.3.5. Fluxo de Gases 25

3.3.6. Campo Magnético 25

3.3.7. Frequência 26

3.4. Câmara de Deposição 27

3.4.1. Parte Externa 27

3.4.2. Parte Interna 31

3.5. Linha de Gases 33

3.6. Componentes Elétricos $\quad 35$

3.6.1. Geração do Plasma 35

3.6.2. Auxílio na Deposição 35

3.6.3. Controle da Temperatura de Deposição 36

3.7. Instrumentos de Medida 37

3.7.1. Medidores de Pressão 38

3.7.2. Medidor de Temperatura 38

3.7.3. Medidor da Tensão Bias 38

3.7.4. Medidor do Fluxo de Gases 39

3.8. Componentes de Vácuo 39

3.9. Preparação do Substrato para a Deposição $\quad 40$

3.10. Operação do Reator $\quad 40$

3.11. Caracterização do Reator 44

SEÇÃO 4 - CARACTERIZAÇÃO DOS FILMES 46

4.1. Introdução 46

4.2. Caracterização Elétrica e Eletro-Óptica 48 
4.2.1. Fotocondutividade 48

4.2.2. Condutividade no Escuro 50

4.2.3. Foto-Sensibilidade 53

4.2.4. Medida do Fator $\gamma \quad 54$

4.2.5. Medida do Comprimento de Difusão Ambipolar 58

4.2.6. Resultados Experimentais $\quad 72$

4.3. Caracterização Óptica 80

4.3.1. Resultados Experimentais 83

4.4. Caracterização Estrutural 83

4.4.1. Densidade de Estados no Gap 86

4.4.2. Número de Ligações $\mathrm{Si}-\mathrm{H}$ e $\mathrm{SiH}_{2}$

4.4.3. Resultados Experimentais 95

4.5. Otimização dos Parâmetros de Deposição 101

SEÇÃO 5 - QUADRO RESUMO COMPARATIVO DOS RESULTADOS EXPERIMENTAIS 104

5.1. Introdução 104

5.2. Comparação entre os Processos $60 \mathrm{~Hz}$ e RF 104

SEÇÃO 6 - CONCLUSÕES E SUGESTÕES PARA FUTUROS TRABALHOS 


\section{LISTA DE FIGURAS}

Figura 2.1. Modelo de Deposição de a-Si:H a partir da Descarga Luminescente de Silana.

Figura 2.2. Modelo de Reações que ocorrem na Superficie do Substrato envolvendo Radicais.

Figura 3.1. Reator com Geometria de Triodo: a) com o Substrato no Terceiro Eletrodo; b) com a Grade do Terceiro Eletrodo Aterrada.

Figura 3.2. Vista Externa da Câmara de Deposição.

Figura 3.3. Esquema da Tampa Inferior da Câmara de Deposição.

Figura 3.4. Esquema das Grades usadas como Eletrodos Ativos no Processo de Deposição.

Figura 3.5. Esquema do Porta-Substrato usado na Deposição.

Figura 3.6. Vista Interna da Câmara de Deposição.

Figura 3.7. Esquema da Câmara de Mistura.

Figura 3.8. Curva de Resposta Temporal da Temperatura no PortaSubstrato para Várias Correntes Elétricas que passam Através da Resistência usada para aquecê-lo. 
Figura 3.9. Vista Completa do Reator de Descarga Luminescente a 60 Hz usado para a Produção de a-Si:H.

Figura 3.10. Vista Esquemática do Reator de Descarga Luminescente a $60 \mathrm{~Hz}$, com Destaque para o Painel de Operações.

Figura 4.1. Esquema Experimental usado para medir a Fotocondutividade.

Figura 4.2. Câmara projetada para medir a Condutividade no Escuro.

Figura 4.3. Esquema Experimental usado para medir o fator $\gamma$.

Figura 4.4. Esquema Experimental para medir o Comprimento de Difusão Ambipolar pela Técnica SSPG (Steady State Photocarmier Grating).

Figura 4.5. Vista Esquemática da Alimentação Elétrica (Fonte DC) e Leitura via Lock-in para a Medida do Comprimento de Difusão Ambipolar. No Desenho vemos com Ênfase o Ponto de Incidência dos dois feixes Laser, onde Eventualmente eles se interferem, criando uma Grade de Período $\Lambda$, Perpendicular à Direção $x$.

Figura 4.6. Medida da Condutividade no Escuro e da Fotocondutividade em Amostras depositadas a $60 \mathrm{~Hz}$ em Função da Pressão de Deposição: a) para Fluxo de $\mathrm{SiH}_{4}$ de $10 \mathrm{ml} / \mathrm{min}$; b) para Fluxo de $\mathrm{SiH}_{4}$ de $100 \mathrm{ml} / \mathrm{min}$. Em ambos os casos a densidade de potência usada foi de $0,01 \mathrm{~W} / \mathrm{cm}^{2}$, e a temperatura do substrato usada foi de $150^{\circ} \mathrm{C}$. 
Figura 4.7. Medida da Condutividade no Escuro e da Fotocondutividade em Amostras depositadas a $60 \mathrm{~Hz}$ em Função da Temperatura do Substrato: a) para Fluxo de $\mathrm{SiH}_{4}$ de $10 \mathrm{ml} / \mathrm{min}$; b) para Fluxo de $\mathrm{SiH}_{4}$ de $100 \mathrm{ml} / \mathrm{min}$. Em ambos os casos a densidade de potência usada foi de $0,01 \mathrm{~W} / \mathrm{cm}^{2}$, e a pressão de deposição usada foi de 0,5 torr.

Figura 4.8. Medida da Energia de Ativação da Condutividade no Escuro de Amostras depositadas a $60 \mathrm{~Hz}$ em Função da Pressão de Deposição: a) para Fluxo de $\mathrm{SiH}_{4}$ de $10 \mathrm{ml} / \mathrm{min}$; b) para Fluxo de $\mathrm{SiH}_{4}$ de $100 \mathrm{ml} / \mathrm{min}$. Em ambos os casos a densidade de potência usada foi de $0,01 \mathrm{~W} / \mathrm{cm}^{2}$, e a temperatura do substrato usada foi de $150^{\circ} \mathrm{C}$.

Figura 4.9. Medida de Energia de Ativação da Condutividade no Escuro de Amostras depositadas a $60 \mathrm{~Hz}$ em Função da Temperatura do Substrato: a) para Fluxo de $\mathrm{SiH}_{4}$ de $10 \mathrm{ml} / \mathrm{min}$; b) para Fluxo de $\mathrm{SiH}_{4}$ de $100 \mathrm{ml} / \mathrm{min}$. Em ambos os casos a densidade de potência usada foi de $0,01 \mathrm{~W} / \mathrm{cm}^{2}$, e a pressão de deposição usada foi de 0,5 torr.

Figura 4.10. Medida do Fator $\gamma$ de Amostras depositadas a $60 \mathrm{~Hz}$ em Função da Pressão de Deposição: a) para Fluxo de $\mathrm{SiH}_{4}$ de $10 \mathrm{ml} / \mathrm{min}$; b) para Fluxo de $\mathrm{SiH}_{4}$ de $100 \mathrm{ml} / \mathrm{min}$. Em ambos os casos a densidade de potência usada foi de $0,01 \mathrm{~W} / \mathrm{cm}^{2}$, e a temperatura do substrato usada foi de $150^{\circ} \mathrm{C}$.

Figura 4.11. Medida do Fator $\gamma$ de Amostras Depositadas a $60 \mathrm{~Hz}$ em Função da Temperatura do Substrato: a) para Fluxo de $\mathrm{SiH}_{4}$ de 10 
$\mathrm{ml} / \mathrm{min}$; b) para Fluxo de $\mathrm{SiH}_{4}$ de $100 \mathrm{ml} / \mathrm{min}$. Em ambos os casos a densidade de potência usada foi de $0,01 \mathrm{~W} / \mathrm{cm}^{2}$, e a pressão de deposição usada foi de 0,5 torr.

Figura 4.12. Espectro de Transmissão Característico do a-Si:H na Região de Luz Visivel. O Desenho Mostra Todas as Regiões de Interesse discutidas no Texto.

Figura 4.13. Medida do Gap Óptico de Amostras depositadas a $60 \mathrm{~Hz}$ em Função da Pressão de Deposição: a) para Fluxo de $\mathrm{SiH}_{4}$ de 10 $\mathrm{ml} / \mathrm{min}$; b) para Fluxo de $\mathrm{SiH}_{4}$ de $100 \mathrm{ml} / \mathrm{min}$. Em ambos os casos a densidade de potência usada foi de $0,01 \mathrm{~W} / \mathrm{cm}^{2}$, e a temperatura do substrato usada foi de $150^{\circ} \mathrm{C}$.

Figura 4.14. Medida do Gap Óptico de Amostras depositadas a $60 \mathrm{~Hz}$ em Função da Temperatura do Substrato: a) para Fluxo de $\mathrm{SiH}_{4}$ de 10 $\mathrm{ml} / \mathrm{min}$; b) para Fluxo de $\mathrm{SiH}_{4}$ de $100 \mathrm{ml} / \mathrm{min}$. Em ambos os casos a densidade de potência usada foi de $0,01 \mathrm{~W} / \mathrm{cm}^{2}$, e a pressão de deposição usada foi de 0,5 torr.

Figura 4.15. Dispositivo Experimental montado para a Técnica $C P M$ (Constant Photocurrent Method).

Figura 4.16. Espectro do Coeficiente de Absorção Caracterísitico do aSi:H obtido pela técnica CPM (Constant Photocurrent Method) na Região do Infra-Vermelho Próximo.

Figura 4.17. Espectro do Coeficiente de Absorção obtido pela Técnica CPM (Constant Photocurrent Method): a) para Amostra depositada a 
$60 \mathrm{~Hz}$ com Fluxo de $\mathrm{SiH}_{4}$ a $10 \mathrm{ml} / \mathrm{min}$; b) para Amostra depositada a $60 \mathrm{~Hz}$ com Fluxo de $\mathrm{SiH}_{4}$ a $100 \mathrm{ml} / \mathrm{min}$; c) para Amostra depositada a RF. No caso das amostras depositadas a $60 \mathrm{~Hz}$ a pressão de deposição usada foi de 0,5 torr, e a temperatura do substrato $170^{\circ} \mathrm{C}$.

Figura 4.18. Medida do Número de Ligações $\mathrm{SiH}$ e $\mathrm{SiH}_{2}$ de Amostras depositadas a $60 \mathrm{~Hz}$ em Função da Pressão de Deposição: a) para Fluxo de $\mathrm{SiH}_{4}$ de $10 \mathrm{ml} / \mathrm{min}$; b) para Fluxo de $\mathrm{SiH}_{4}$ de $100 \mathrm{ml} / \mathrm{min}$. Em ambos os casos a densidade de potência usada foi de $0,01 \mathrm{~W} / \mathrm{cm}^{2}$, e a temperatura do substrato usada foi de $150^{\circ} \mathrm{C}$.

Figura 4.19. Medida do Número de Ligações $\mathrm{SiH}$ e $\mathrm{SiH}_{2}$ de Amostras depositadas a $60 \mathrm{~Hz}$ em Função da Temperatura do Substrato: a) para Fluxo de $\mathrm{SiH}_{4}$ de $10 \mathrm{ml} / \mathrm{min}$; b) para Fluxo de $\mathrm{SiH}_{4}$ de $100 \mathrm{ml} / \mathrm{min}$. Em ambos os casos a densidade de potência usada foi de $0,01 \mathrm{~W} / \mathrm{cm}^{2}$, e a pressão de deposição usada foi de 0,5 torr.

Figura 4.20. Espectro de Transmissão no Infra-Vermelho Distante: a) para Amostra depositada a $60 \mathrm{~Hz}$ com Fluxo de $\mathrm{SiH}_{4}$ a $10 \mathrm{ml} / \mathrm{min}$; b) para Amostra depositada a $60 \mathrm{~Hz}$ com Fluxo de $\mathrm{SiH}_{4}$ a $100 \mathrm{ml} / \mathrm{min}$; c) para Amostra depositada a RF. Nas amostras depositadas a $60 \mathrm{~Hz}$ a densidade de potência usada foi de $0,01 \mathrm{~W} / \mathrm{cm}^{2}$, a temperatura do substrato foi de $170^{\circ} \mathrm{C}$, e a pressão de deposição foi de 0,5 torr.

Figura 4.21. Medida da Taxa de Deposição de Amostras depositadas a $60 \mathrm{~Hz}$ em Função da Pressão de Deposição: a) para Fluxo de $\mathrm{SiH}_{4}$ de $10 \mathrm{ml} / \mathrm{min}$; b) para Fluxo de $\mathrm{SiH}_{4}$ de $100 \mathrm{ml} / \mathrm{min}$. Em ambos os casos a densidade de potência usada foi de $0,01 \mathrm{~W} / \mathrm{cm}^{2}$, e a temperatura do substrato usada foi de $150^{\circ} \mathrm{C}$. 
Figura 4.22. Medida da Taxa de Deposição de Amostras depositadas a $60 \mathrm{~Hz}$ em Função da Temperatura do Substrato: a) para Fluxo de $\mathrm{SiH}_{4}$ de $10 \mathrm{ml} / \mathrm{min}$; b) para Fluxo de $\mathrm{SiH}_{4}$ de $100 \mathrm{ml} / \mathrm{min}$. Em ambos os casos a densidade de potência usada foi de $0,01 \mathrm{~W} / \mathrm{cm}^{2}$, e a pressão de deposição usada foi de 0,5 torr. 


\section{LISTA DE TABELAS}

Tabela 5.1. Propriedades dos Melhores Filmes depositados a $60 \mathrm{~Hz}$ para Fluxo de $\mathrm{SiH}_{4}$ a 10 e $100 \mathrm{ml} / \mathrm{min}$, comparados com Filmes depositados a RF. 


\section{RESUMO}

Apresentamos neste trabalho uma técnica alternativa para a obtenção de filmes finos de silício amorfo hidrogenado $(a$-Si:H). Nós depositamos $a$-Si:H em um sistema de deposição que utiliza descarga luminescente a baixas frequências $(60 \mathrm{~Hz})$. Para tanto, nós projetamos todo o reator para que este objetivo pudesse ser atingido.

Os filmes obtidos por nós mostram propriedades ópticas e eletrônicas bastante próximas àquelas dos filmes produzidos pela técnica convencional de descarga luminescente a rádio-frequência $(13,56 \mathrm{MHz})$. A temperatura do substrato ótima para a técnica de descarga luminescente a baixas frequências está na faixa $150-170^{\circ} \mathrm{C}$, em torno de $100^{\circ} \mathrm{C}$ menor do que aquela usada para rádio-frequência.

Neste trabalho nós apresentamos medidas das propriedades dos filmes, incluindo condutividade no escuro, fotocondutividade, comprimento de difusão ambipolar, absorção no infra-vermelho, gap óptico, e densidade de defeitos de níveis profundos. Para realizar parte destas medidas, nós construímos sistemas experimentais de caracterização exclusivos para o $a-\mathrm{Si}: \mathrm{H}$. 
ABSTRACT

In this work we present an alternative technique for producing hydrogenated amorphous silicon thin films ( $a$-Si:H). We deposited $a$-Si:H in a low-frequency (60 $\mathrm{Hz}$ ) glow-discharge deposition system. For this purpose, we designed completely the reactor.

The films we produced show electronic and optical properties nearly equivalent to those of films prepared by the conventional radio-frequency $(13,56 \mathrm{MHz})$ glowdischarge technique. The optimal substrate temperature for the low-frequency glowdischarge technique is $150-170^{\circ} \mathrm{C}$, about $100^{\circ} \mathrm{C}$ lower than that at radio-frequency.

In this work, we report measurements of film properties, including dark conductivity, photoconductivity, ambipolar diffusion lenght, infrared absorption, optical band gap, and deep defect density. To do these measurements, we assembled experimental systems used to characterize $a-\mathrm{Si}: \mathrm{H}$.

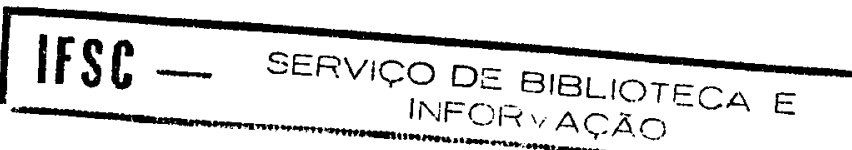




\section{SEÇÃO 1}

\section{INTRODUÇÃO}

Silício amorfo hidrogenado ( $a$-Si:H) e suas ligas tem sido largamente usado como filme fino semicondutor em aplicações tais como células solares fotovoltaicas, fotoreceptores para eletrofotografia, transistores de filmes finos para o controle de mostradores de tela plana, e sensores de imagens. Este material tem elevado coeficiente de absorção óptico na região da luz visível e boas propriedades semicondutoras, quer intrínseco, quer quando dopado. Mas a sua principal vantagem é que o $a$-Si:H pode ser facilmente depositado, a baixo custo, sobre substratos de quase qualquer forma e tamanho pelo método de deposição a partir de vapor químico assistido por plasma (plasma assisted chemical vapor deposition - (VD).

A deposição a partir de vapor químico assistida por plasma é também chamada deposição a descarga luminescente (glow discharge) por causa da visivel luminosidade, que é principalmente resultante da de-excitação das espécies atômicas e moleculares contidas no plasma. A descarga luminescente é sustentada por processos inelásticos envolvendo o impacto de elétrons sobre as espécies do plasma, que são iniciados por elétrons que adquirem energia suficiente do campo elétrico como resultado de sucessivas colisões elásticas com as moléculas gasosas. Quando um plasma de silano $\left(\mathrm{SiH}_{4}\right)$ é usado, o processo inelástico conduz a espécies neutras reativas, tais como $\mathrm{SiH}, \mathrm{SiH}_{2}, \mathrm{SiH}_{3}, \mathrm{Si}_{2} \mathrm{H}_{6}, \mathrm{H} \mathrm{e} \mathrm{H}_{2}$, e espécies ionizadas, tais como $\mathrm{SiH}^{+}, \mathrm{SiH}_{2}{ }^{+}, \mathrm{SiH}_{3}{ }^{+}$, e assim por diante.

A descarga luminescente tem se tornado a técnica mais comum para a deposição de $a$-Si:H e dispositivos para aplicações fotovoltaicas. A decomposição assistida por plasma reduz a temperatura exigida para o processo de deposição; esta menor temperatura do substrato torna possível a incorporação de quantidades suficientes de hidrogênio durante a deposição. Sob certas condições, o bombardeamento do filme por ions induzidos por plasma durante a deposição tende a melhorar a qualidade do filme. 
O campo elétrico usado para iniciar o plasma normalmente é um campo de rádio-frequência $(R F)$ e eventualmente usa-se um campo de corrente contínua (DC). $O$ objetivo deste trabalho é demonstrar, sob certas condições de pressão de deposição e temperatura do substrato, a viabilidade da obtenção de filmes finos de $a$-Si:H com qualidade eletrônica usando um campo elétrico alternado de $60 \mathrm{~Hz}$. Os resultados experimentais mostram que as condições de deposição usando um campo elétrico a 60 $\mathrm{Hz}$, onde obtivemos amostras com excelentes propriedades envolvem temperaturas de substrato cerca de $100{ }^{\circ} \mathrm{C}$ abaixo das temperaturas usando-se RF. Isto pode permitir o uso desta técnica para depositar filmes finos de $a-\mathrm{Si}: \mathrm{H}$ em substratos alternativos, que sejam sensiveis a temperaturas acima de $170 \mathrm{C}$. Uma outra vantagem evidente do uso de uma tensão $\mathrm{AC}$ de $60 \mathrm{~Hz}$ para produzir o plasma é que podemos tomá-la diretamente da rede elétrica que assiste o laboratório.

A Seção 2 traz um pequeno histórico da pesquisa do $a$-Si:H obtido por descarga luminescente. Neste capitulo procuramos dar uma visão geral do processo, destacando os mecanismos envolvidos na deposição de filmes de $a$-Si:H.

Na Seção 3 descrevemos o reator de descarga luminescente desenvolvido em nosso laboratório. Nosso objetivo foi a substituição da fonte usual de rádio-frequência por uma fonte $\mathrm{AC}$ a $60 \mathrm{~Hz}$, até então não estudada; com isto pretendemos dar uma contribuição no sentido de introduzir esta nova técnica de obtenção deste material eletrônico. Como introdução ao projeto do reator, listamos os principais parâmetros envolvidos na técnica e seus possíveis efeitos sobre as propriedades finais do filme.

Na Seção 4 descrevemos com detalhes as técnicas usadas para a caracterização dos filmes finos de $a$-Si:H. Duas foram as linhas gerais desta caracterização:

i) o estudo de propriedades ópticas, tais como absorção no infra-vermelho e absorção no visível, em função das condições de deposição;

ii) o estudo de propriedades elétricas fundamentais, tais como condutividade no escuro e fotocondutividade, em função das condições de deposição;

iii) o estudo de técnicas eletro-ópticas específicas para o $a$-Si:H, para as amostras com condições óptimas de deposição; descrevemos com detalhes as técnicas 
conhecidas como Constant Photocurrent Method, usada para determinar a densidade de defeitos presentes no gap de energia, e Steady State Photocurrent Grating, usada para determinar o comprimento de difusão dos portadores no semicondutor.

Ainda na Seção 4, apresentamos os resultados obtidos em filmes produzidos com nosso reator. Para que tivéssemos uma boa idéia a respeito da qualidade dos nossos filmes, fizemos uma comparação das propriedades de nossos filmes com resultados em filmes produzidos em um reator do tipo $R F$-Glow Discharge obtidos no National Renewable Energy Laboratory (NREL), CO, USA.

Na Seção 5 apresentamos um quadro resumo das propriedades de filmes finos de $a$-Si:H depositados a $60 \mathrm{~Hz}$, comparando-as com as de filmes obtidos de forma convencional.

Finalmente, na Seção 6 apresentamos as conclusões que chegamos ao longo da realização deste trabalho, bem como sugestões para a continuidade da pesquisa. 


\section{SEÇÃO 2}

\section{PRODUÇÃO DE FILMES AMORFOS PELA TÉCNICA DE DESCARGA LUMINESCENTE}

\subsection{Um pouco de História}

Os estudos preliminares sobre $a$-Si:H iniciaram-se em 1965 num trabalho de Sterling e Swann ${ }^{1}$, e prosseguiram anos mais tarde, em 1968 com o trabalho de Chittick et $a l^{2}$. Estes autores demonstraram a possibilidade de obtenção de silício amorfo hidrogenado a partir de uma descarga luminescente de gás silana. Deve ser observado que estes estudos envolviam a produção de $a$-Si:H a partir de uma descarga aplicada através de uma bobina sujeita a uma corrente de RF, isto é, o reator era do tipo indutivo; este processo envolvia um tubo de quartzo evacuado, sobre o qual era depositado o filme. Hoje em dia os reatores comerciais são do tipo capacitivo, com a presença de eletrodos internos à câmara.

A isto seguiu o trabalho de Spear e Le Comber ${ }^{3}$, que registraram o sucesso da dopagem $n$ e $p$ no $a$-Si:H. Este trabalho mostrou que é possível a dopagem substitucional em semicondutores amorfos, particularmente $a$-Si e $a$-Ge; contudo, a principal exigência que determina a adequabilidade para a dopagem destes semicondutores é que o material tenha uma densidade de estados no gap bastante baixa; para o $a$-Si isto é conseguido quando ele é depositado pelo processo de descarga luminescente a $\mathrm{RF}$ a uma temperatura de substrato de cerca de $230^{\circ} \mathrm{C}$. A dopagem é alcançada adicionando-se com cuidado quantidades medidas de fosfina e diborana à mistura gasosa no reator para obter amostras do tipo $n$ ou do tipo $p$, respectivamente.

Em 1976, a primeira célula solar usando silício amorfo hidrogenado foi fabricada nos laboratórios da $\mathrm{RCA}^{4}$. Este fato é digno de nota, já que ele anuncia uma viabilidade prática para os filmes finos de $a$-Si:H. A estrutura desta célula solar envolvia, primeiro a deposição de algumas centenas de angstrons de $a$-Si dopado com boro (camada tipo $p$ ); a seguir, uma camada intrínseca (não dopada) de cerca de $1 \mu \mathrm{m}$ 
de espessura é depositada, e então algumas centenas de angstrons de $a$-Si dopado com fósforo (camada tipo $n$ ); finalmente, um eletrodo de alumínio foi evaporado sobre a estrutura $p-i-n$ para formar um contato de baixa resistência com a camada $n$. Esta primeira célula solar mostrava uma eficiência de $2,4 \%$ quando submetida a ação da luz solar; de lá até os dias de hoje muito tem sido feito para aumentar esta eficiência, sendo que cerca de duas dezenas de grupos no mundo todo desenvolveram células com mais de $10 \%$ de eficiência de conversão.

$O$ aumento na eficiência de células solares e do desempenho de outros dispositivos à base de silício amorfo hidrogenado envolve a necessidade de melhorar as propriedades de transporte de portadores nestes materiais. Além disso, existem outros problemas nestes materiais que necessitam ser atacados através do refino nas técnicas de deposição. Um dos mais importantes é que células solares de $a$-Si perdem eficiência quando expostas à luz, devido ao conhecido Efeito Staebler-Wronski ${ }^{5}$. Neste caso, a eficiência das células após um longo tempo de uso é consideravelmente menor do que o seu valor inicial. Defeitos metaestáveis similares ao Efeito Staebler-Wronski podem também ser induzidos termicamente ou por injeção de portadores quando uma diferença de potencial elétrica é aplicada no filmé

Um outro problema é obter materiais com boas propriedades à taxas de deposição suficientemente elevadas que permitam a produção de filmes como uma atividade econômica. Até agora, a qualidade do filme e a eficiência dos dispositivos diminuem à medida que a taxa de deposição aumenta.

Finalizando a lista de problemas, existe a dificuldade encontrada na dopagem de a-Si:H e suas ligas. Apenas o boro e o fósforo são usados rotineiramente como dopantes para estes materiais. Mesmo para estes dopantes, a eficiência na dopagem é muito baixa; propriedades elétricas importantes de materiais dopados, tais como a densidade de ligações insaturadas, e o tempo de vida e o comprimento de difusão dos portadores são muito ruins ${ }^{7}$. Recentemente Castilho et al demonstraram a possibilidade de dopar $a$-Si com elementos terras-raras ${ }^{8}$, o que poderia criar novas possibilidades do estudo em sistemas amorfos através de medidas das transições ópticas destes dopantes. 
A superação de todas estas dificuldades - a baixa eficiência das células solares, a baixa qualidade das ligas, a degradação induzida por luz, as baixas taxas de deposição, e a pequena eficiência de dopagem - pode estar na melhora dos processos de deposição. Estes devem ser conduzidos no sentido de melhorar o controle da composiçăo química e da quantidade de defeitos do filme depositado. $\mathrm{O}$ método usado na deposição e os parâmetros usados no processo determinam as propriedades do $a$ $\mathrm{Si}: \mathrm{H}$, tais como distorções nas ligações, defeitos pontuais, e defeitos na microestrutura. Por sua vez, estes defeitos determinam as propriedades eletrônicas dos filmes, tais como estados de defeito presentes em estados profundos e no gap de energia, os quais limitam a eficiência da conversão fotovoltaica. Estes defeitos podem também determinar a magnitude da degradação induzida por iluminação. Estudos sistemáticos são necessários para relacionar as condições de deposição às propriedades de defeitos. A necessidade de entender as condições de deposição como um pré-requisito no melhoramento das propriedades do filme é a razão para o interesse que alguns grupos tem no diagnóstico do plasma. Existe também algum esforço no sentido de desenvolver métodos de deposição alternativos com o objetivo de eliminar alguns dos problemas levantados acima.

Embora os métodos de deposição convencionais usando descarga luminescente tenham produzido filmes de $a$-Si:H de boa qualidade, eles permitem muito pouco controle sobre o processo de deposição. Os parâmetros de deposição que podem ser usados para depositar filmes de elevada qualidade estão interrelacionados e a otimização de cada um reside em uma faixa bastante estreita. Como consequência desta perda de controle, poucos melhoramentos foram feitos a partir desta técnica para a solução dos problemas listados acima. Além disto, por causa da complexidade do processo, existem ainda muitas questões relacionadas aos mecanismos de crescimento na deposição por descarga luminescente. Assim, é importante investigar métodos alternativos de deposição que possam melhorar a qualidade dos filmes de $a$-Si:H e suas ligas, aumentar o entendimento dos mecanismos de crescimento do filme, e permitir um melhor controle das propriedades do filme. Um excelente artigo de revisão a 
respeito de processos alternativos de deposição de $a$-Si:H e suas ligas foi escrito por Tsuo e Luft ${ }^{9}$.

\subsection{Medidas de Diagnóstico}

Uma variedade de medidas de diagnóstico, tanto para o plasma, quanto para os filmes depositados é empregada para determinar os constituintes do plasma e a qualidade do filme, respectivamente. 0 plasma não foi objeto de estudo desta Tese, de forma que citaremos aqui apenas as técnicas mais usadas em sua caracterização. Quanto à qualidade do filme, a Seção 4 é toda ela dedicada às técnicas por nós utilizadas para esta caracterização.

As medidas de diagnóstico do plasma in situ incluem a espectroscopia de massa $(M E)$, a espectroscopia de emissão óptica (OES), a espectroscopia de absorção de fase gasosa, a espectroscopia coerente Raman anti-Stokes (CARS), e a fluorescência induzida por laser $(L I F)$. Obviamente, a espectroscopia de massa e a espectroscopia de emissão óptica são as mais utilizadas devido a facilidade no arranjo experimental.

A espectroscopia de massa é usada para medir ions e espécies neutras no plasma; um espectrômetro de massa de quadrupolo disponível comercialmente, consistindo de um ionizador, um quadrupolo de massa, e de um detetor, é geralmente usado por causa de sua elevada sensibilidade, rápida varredura, boa resolução, escala linear de massa, e pequeno tamanho. Para melhorar a sensibilidade e medir espécies pouco abundantes no plasma, é possível usar um ionizador do tipo feixe de elétrons confinado magneticamente e um espectrômetro de massa usual; neste caso, alcança-se uma precisão de 1 radical em $10^{6}$ moléculas de $\mathrm{SiH}_{4}{ }^{10}$.

A espectroscopia de emissão óptica nas regiões visível e ultra-violeta é comumente usada para determinar a presença de espécies neutras e iônicas no plasma $^{11}$. A principal vantagem da $O E S$ é que ela não perturba o plasma, e também pode ser usada para monitorá-lo quando é desejável obter condicões reprodutiveis para o plasma. Contudo, a OES fornece apenas dados semiquantitativos sobre as concentrações e processos de excitação. 
A espectroscopia de absorção pode ser usada para identificar um grande número de moléculas estáveis em um gás. Uma possibilidade é a utilização de um laser de diodo sintonizável na região do infra-vermelho para a detecção sensitiva e seletiva de espécies.

A espectroscopia coerente Raman anti-Stokes (CARS) é excelente para medir a distribuição espacial de moléculas neutras, mesmo na presença de uma forte emissão de fundo proveniente do plasma. Ela pode ser usada para medir as concentrações de $\mathrm{SiH}_{4}$ e $\mathrm{H}_{2}$ durante o processo de descarga luminescente de silana.

A fluorescência induzida por laser $(L I F)$ é uma forma de medir a distribuição das espécies neutras no plasma. Ela oferece uma grande resolução espacial, maior sensibilidade e melhor seletividade do que a OES. A LIF pode detetar espécies complementares àquelas detetadas por $C A R S$, como por exemplo Si e $\mathrm{SiH}$.

\subsection{Mecanismos Envolvidos na Deposição de a-Si:H}

Existem quatro estágios na formação do $a-\mathrm{Si}: \mathrm{H}$ a partir de uma descarga elétrica em um reator contendo silana. O primeiro, o processo de impacto de elétrons, é a dissociação colisional primária da silana, resultando em uma mistura de espécies reativas consistindo de íons e radicais livres. O segundo estágio é a difusão ou arraste destas espécies até a superfície do substrato, acompanhada por uma multiplicidade de reações secundárias envolvendo íons-moléculas, fótons-moléculas, etc. $O$ terceiro estágio é a reação das espécies do gás ou plasma com as suas adsorções na superficie do substrato. O quarto estágio é o processo pelo qual estas espécies ou seus produtos de reação incorporam-se no filme em crescimento, ou são re-emitidos da superfície do substrato para a fase gasosa.

Kampas ${ }^{12}$ estabeleceu que o processo de deposição básico é a inserção de $\mathrm{SiH}_{2}$ numa ligação $\mathrm{Si}-\mathrm{H}$ para produzir um grupo excitado $\mathrm{SiH}_{3}$ ligado a um átomo de silício. Átomos de hidrogênio podem então ser eliminados por uma variedade de formas; por exemplo, o grupo $\mathrm{SiH}_{3}$ liga-se a uma ligação insaturada para formar um grupo $\mathrm{Si}_{-} \mathrm{SiH}_{3}$ de elevada energia interna, a partir do qual átomos de hidrogênio são eliminados. 
Gallagher ${ }^{13}$ forneceu um modelo para a deposição de $a$-Si:H a partir de silana pelo processo de descarga luminescente, como mostrado na Figura 2.1. e na Figura 2.2. Na Figura 2.1. os processos de colisão envolvendo elétrons são mostrados por setas grossas, os processos envolvendo colisões gasosas por setas mais finas, e o transporte entre o gás e a superfície pelas setas mais finas. As reações químicas são iniciadas por colisões entre elétrons e moléculas de silana, produzindo íons e radicais neutros. Colisões sucessivas destes íons com moléculas de silana convertem estes íons em íons ainda mais pesados, em competição com a velocidade de arraste dos íons para os eletrodos. O resultado destas reações sob condições típicas é a significante, mas não muito grande, fração de íons ( múltiplos de $\mathrm{Si}$ ) mais pesados. Se os íons mais pesados fossem produzidos em grandes quantidades, eles continuariam a crescer através da interação entre ion-molécula, até que eles nucleassem em particulados que destruiriam a qualidade do filme em deposição. Para impedir tal nucleação, uma pequena distância eletrodo-substrato é desejada.

Os radicais neutros reagindo com moléculas de silana conduzem a vários processos. O mais importante é aquele em que o radical neutro dominante produzido pelo elétron inicialmente excitado (hidrogênio atômico), é convertido em radical $\mathrm{SiH}_{3}$ pela reação com a silana. Ao mesmo tempo, à pressões de deposição típicas (0,1-1,0 torr), os radicais $\mathrm{SiH}, \mathrm{SiH}_{2}$ e $\mathrm{Si}$ reagem com moléculas de silana e hidrogênio para formar radicais di-silana e di-silício, antes de atingirem a superfície do substrato. $O$ resultado destas reações envolvendo radicais neutros e da produção de $\mathrm{SiH}_{3}$ pela reação iônica é a difusão do radical $\mathrm{SiH}_{3}$ para a superfície. Assim, o radical $\mathrm{SiH}_{3}$ é o precursor da deposição do $a$-Si:H a baixas potências, descarga DC a altas pressões e descarga RF. Este modelo está de acordo com medidas indicando que as constantes de velocidade para reações de $\mathrm{SiH}_{2}$ com $\mathrm{H}_{2}, \mathrm{SiH}_{4}$ e $\mathrm{Si}_{2} \mathrm{H}_{6}$ são $10^{4}, 10^{2}$ e 10 vezes mais elevadas do que valores previamente calculados a partir de valores da literatura para os parâmetros de Arrhenius ${ }^{14}$. Contudo, para potência elevada, baixa pressão (menor do que 50 mtorr), o precursor dominante não é necessariamente o radical $\mathrm{SiH}_{3} 15$. 


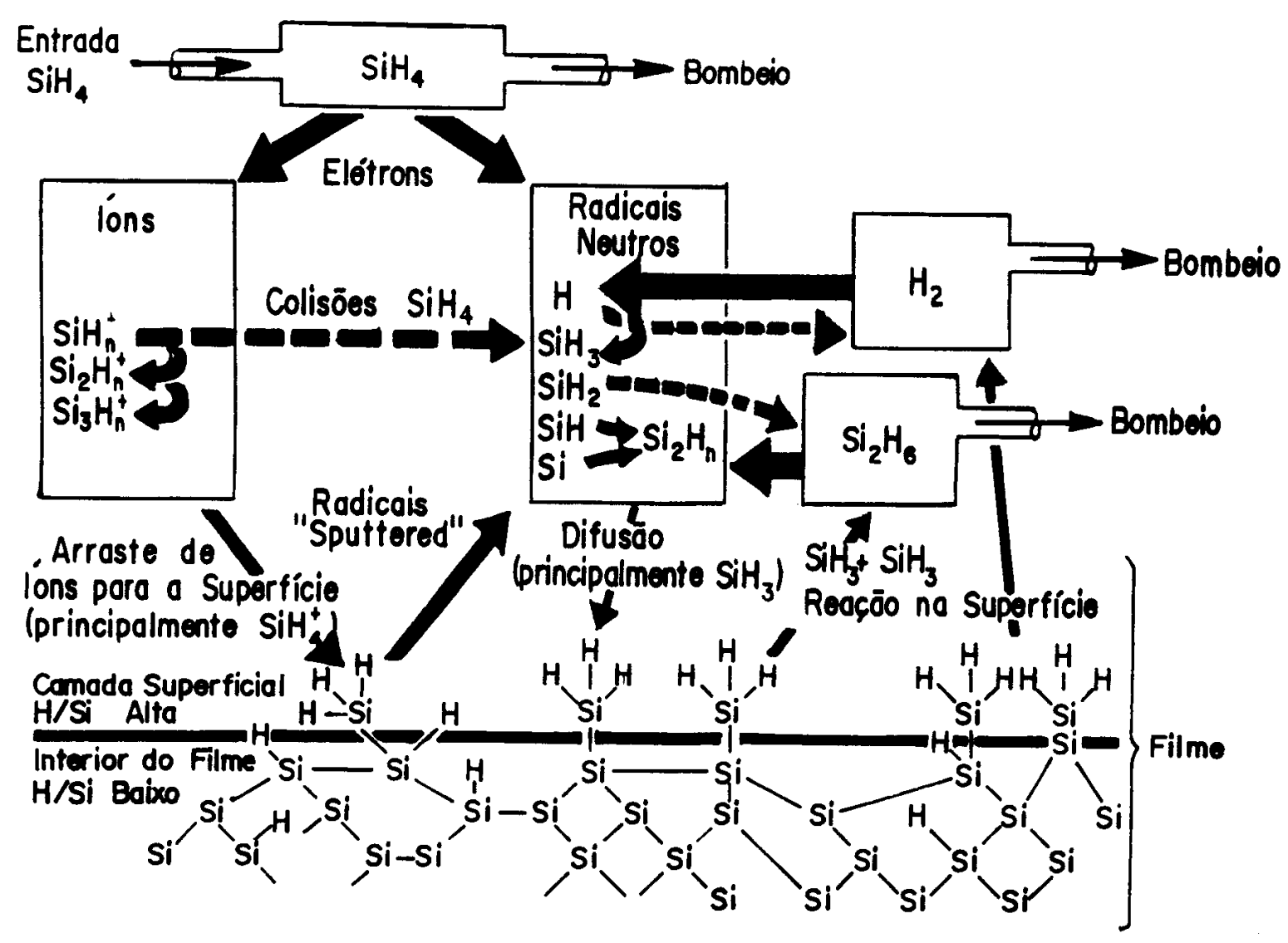

Figura 2.1. Modelo de Deposição de $a$-Si:H a partir da Descarga Luminescente de Silana.

Radicais ejetados da superficie do substrato por bombardeamento de íons adicionam-se àqueles produzidos pela química do gás, e em certas condições são a fonte de radicais dominante. Di-silana é produzida na descarga luminescente de silana por reações superficiais de dois radicais $\mathrm{SiH}_{3}$. A fonte primária da molécula de hidrogènio é a conversão de dois radicais $\mathrm{SiH}$ ligados à superfície em ligações Si-Si com a liberação de $\mathrm{H}_{2}$.

$\mathrm{Na}$ superfície do $a-\mathrm{Si}: \mathrm{H}$ quase todas as ligações superficiais estão presas a átomos de hidrogênio. Sob condições de descarga típicas, apenas 1 em $10^{4}$ ou $10^{5}$ destas ligações envolvendo silício são insaturadas (sem um átomo de hidrogênio). Assim, a produção de filmes de $a$-Si:H ocorre predominantemente pela reação de radicais $\mathrm{SiH}$ com a superfície de silício passivada por átomos de hidrogênio ${ }^{13}$.

Um modelo da deposição inicial na superfície do substrato é mostrado na Figura 2.2. ${ }^{13}$. Qualquer radical $\mathrm{SiH}_{2}$ ou outros radicais com mais de uma ligação insaturada incorporar-se-ão imediatamente no filme de silício coberto com hidrogênio. Por outro 
lado, o radical $\mathrm{SiH}_{3}$ não pode incorporar-se diretamente à ligação $\mathrm{SiH}$, mas pode remover um átomo de hidrogênio para produzir $\mathrm{SiH}_{4}$ e uma ligação insaturada na superficie. Um outro radical $\mathrm{SiH}_{3}$ migrando ao longo da superficie ou vindo diretamente do gás, pode então incorporar-se numa ligação insaturada. Seguindo o passo inicial de incorporação do radical $\mathrm{SiH}_{3}$ na superficie com uma única ligação Si$\mathrm{Si}$, dois radicais $\mathrm{SiH}_{3}$ podem fazer ligações $\mathrm{Si}$-Si adicionais, liberando $\mathrm{H}_{2}$. Este processo requer que os dois átomos de Si tenham aproximadamente o espaço e a morfologia de um cristal, para que a liberação de hidrogênio torne-se exotérmica. Assim, a tendência é o crescimento de estruturas próximas a cristais. À taxas de deposição elevadas, a eliminação de hidrogênio pode ser impedida pela englobação das superficies cobertas por hidrogênio, o que resulta na formação de vazios ${ }^{16}$.

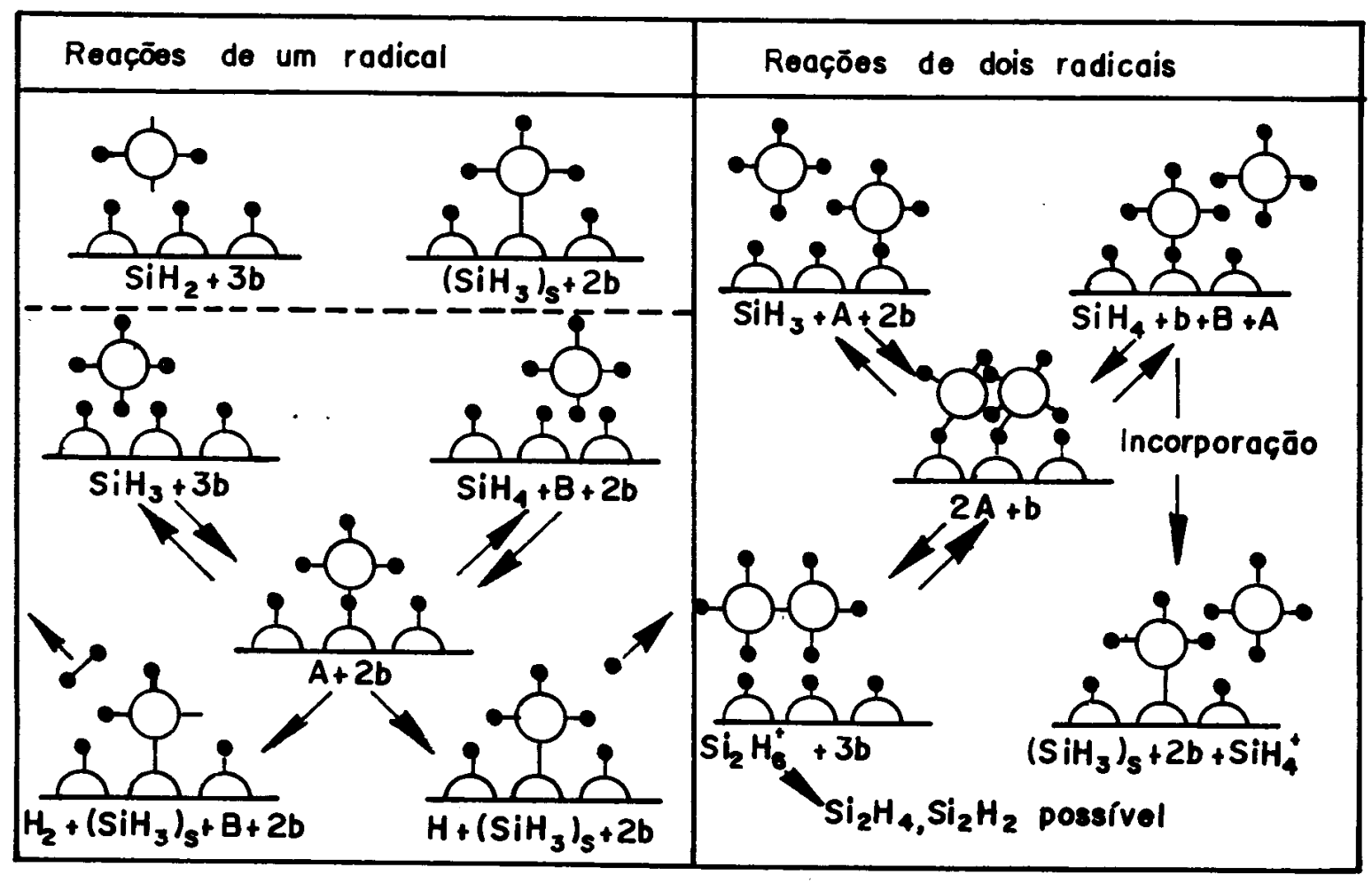

Figura 2.2. Modelo de Reações que ocorrem na Superficie do Substrato envolvendo Radicais. 


\section{SEÇÃO 3}

\section{CONSTRUÇÃO E OPERAÇÃO DO REATOR DE DESCARGA LUMINESCENTE A BAIXAS FREQUÊNCIAS}

\subsection{Introdução}

O objetivo desta Seção é mostrar a viabilidade da construção de um reator de descarga luminescente usando como fonte produtora do plasma um transformador de alta voltagem funcionando a $60 \mathrm{~Hz}$, a fim de produzir filmes finos de silício amorfo hidrogenado $(a-\mathrm{Si}: \mathrm{H})$ de qualidade eletrônica.

A produção de $a$-Si:H e suas ligas em um reator de descarga luminescente ( $g l o w$ ' discharge) pelo processo de deposição a partir de vapor químico (Chemical Vapour Deposition - (VID) introduz riscos potenciais associados com a manipulação de gases comprimidos, tóxicos, pirofóricos, e inflamáveis, tais como silana, fosfina, diborana, germana, hidrogênio, argônio e nitrogênio. À exceção da germana, para todos os demais gases nós projetamos e instalamos as linhas de gases dos cilindros até o reator.

No projeto de construção do reator, todos os esforços foram tomados para eliminar ou reduzir o risco da manipulação destes gases, durante a sua operação e manutenção.

A seguir, descreveremos o projeto de um sistema de deposição, dando ênfase aos principais parâmetros que devem ser levados em conta neste projeto. Por fim, faremos um relato completo das etapas de construção do reator de descarga luminescente a $60 \mathrm{~Hz}$, e de todo o sistema auxiliar usado para a deposição de filmes finos de $a-\mathrm{Si}: \mathrm{H}$.

\subsection{O Projeto de um Sistema de Deposição}

Um sistema de deposição a plasma, como qualquer sistema de deposição a partir de vapor quimico, consiste geralmente de vários subsistemas funcionais, tais como $o$ reator, os subsistemas de armazenamento, controle e fluxo de gases, o sistema de 
bombeamento de alto vácuo, o sistema de efluência de gases, e o circuito elétrico para a geração do plasma, seja ele $\mathrm{AC}$ ou $\mathrm{DC}$.

Na fabricação de dispositivos $p-i-n$ três tipos de reatores têm sido usados:

i) um reator de uma única câmara,

ii) um reator do tipo load-lock com uma única câmara,

iii) e um reator do tipo multicâmara.

O reator de uma única câmara é o mais simples, e consiste de uma única câmara de deposição, a qual é aberta a cada ciclo. Obviamente, este tipo de câmara traz problemas para o produto final obtido, principalmente no que diz respeito à contaminação. Uma possível solução para este problema é o uso de uma jaula de aço inoxidável totalmente fechada dentro da qual o substrato é colocado ${ }^{17}$, e onde ocorre a descarga luminescente. O problema da contaminação é minimizado porque apenas uma pequena fração da superfície da jaula é exposta ao plasma. Além disso, o aquecimento externo reduz a contaminação por desgaseificação. Outra característica deste projeto inclui a boa uniformidade de deposição, sem qualquer acumulação particular.

O reator do tipo load-lock ${ }^{18}$ é similar ao sistema de uma única câmara; contudo, a adição de um sistema load-lock providencia o acesso à câmara principal sem a quebra do vácuo, já que neste projeto existe uma pré-câmara. A transferência do substrato da pré-câmara para a câmara principal é feita em pressões da ordem de 0,5 torr em atmosfera de argônio; após o fechamento da válvula de contato entre estas duas câmaras, um fluxo de silana prepara a câmara de processo para a sequência de deposição; após a deposição a câmara de processo recebe um fluxo de argônio a 0,5 torr, a válvula de contato é aberta, e a transferência do substrato para a pré-câmara é executada. Em um sistema load-lock típico a câmara principal é aberta para limpeza após cerca de 30 deposições; o nível mais elevado de impurezas depositadas na amostra é observada na primeira deposição após a limpeza; isto pode ocorrer devido à formação de depósitos de filmes sobre componentes do sistema, que inibem a desadsorção de gases. 
O reator de descarga luminescente com multicâmaras ${ }^{19}$ consiste de uma sucessão de câmaras em série, uma isolada da outra por válvulas. Em cada câmara um tipo diferente de filme amorfo é depositado; a vantagem óbvia é que o nível de contaminação é bastante reduzido neste sistema.

No projeto de uma câmara de deposição é necessário considerar alguns fatores, tais como a geometria dos eletrodos, o padrão de fluxo de gases e o projeto do aquecedor; outras características de projeto importantes são as paredes quentes, as pequenas distâncias entre os eletrodos, o tamanho dos eletrodos, a eliminação das regiões de campo elevado, a seleção na frequência de excitação e a aplicação de uma tensão de polarização DC de controle. Todas estas características de projeto ou de processo podem afetar a qualidade do filme. Dado que existem numerosas variações e considerações de engenharia no projeto de um sistema de deposição a discussão será aqui limitada àqueles fatores que estão diretamente relacionados com a física e a química do filme crescido.

\subsubsection{A Geometria dos Eletrodos}

O projeto do eletrodo é importante porque ele afeta as reações entre elétrons e moléculas gasosas, o transporte de espécies geradas no plasma para o substrato, e as reações secundárias no substrato, e isto pode afetar a qualidade resultante do filme. Os sistemas de deposição de $a$-Si:H usuais usam um projeto de reator do tipo flat-bed com eletrodos internos. Reatores tubulares com eletrodos externos acoplados indutivamente foram usados nos primórdios da pesquisa em $a-\mathrm{Si}: \mathrm{H}^{1.2}$. Contudo, reatores tubulares são dificeis de ser adaptados para a produção industrial. Uma geometria de eletrodos na forma de triodo com a aplicação de uma tensão de polarização pode minimizar o dano pelo bombardeamento de íons no crescimento dos filmes. O confinamento do plasma, por grades aterradas ou campos magnéticos, minimiza a contaminação do filme a partir das paredes, e pode prover um campo elétrico mais uniforme. Reatores com dois eletrodos são chamados de reatores diodo, e reatores com três eletrodos são chamados de reatores triodo. 
Em reatores diodo o eletrodo que contém o substrato sobre o qual o filme é depositado é tipicamente o eletrodo aterrado. A área combinada do eletrodo aterrado e das paredes da câmara aterradas é geralmente muito maior do que a área do eletrodo carregado. Como resultado desta geometria assimétrica e pelo fato da mobilidade do elétron ser muito maior do que a mobilidade dos íons, as duas regiões dos eletrodos terão diferentes quantidades de queda de potencial, o que acelera ions na direção dos eletrodos e elétrons para longe deles. A maior queda de potencial aparece no eletrodo carregado, o qual é mais negativo em relação ao eletrodo aterrado. Esta é a razão pelo qual o eletrodo carregado é frequentemente chamado de cátodo e o eletrodo aterrado de ânodo. O potencial aterrado é sempre negativo em relação ao potencial do plasma, $e$ então a superfície do substrato sobre o eletrodo aterrado sofre o bombardeamento por íons positivos.

As taxas de deposição para substratos colocados no cátodo são sempre maiores do que as taxas de deposição anódicas, porcausa da auto-polarização negativa. Isto é consistente com o fato de que a geração de radicais neutros toma lugar próxima ao cátodo.

No reator diodo os íons produzidos na descarga são acelerados em regiões de campo elevado no plasma e bombardeiam a superficie do filme em crescimento. Para impedir o dano no filme pelo bombardeamento de íons positivos, uma tela catódica (aterrada) é algumas vezes adicionada próxima ao substrato. Filmes crescidos sobre o cátodo experimentam mais bombardeio de íons do que filmes depositados sobre o ânodo aterrado. Filmes catódicos geralmente contém menos hidrogênio do que filmes anódicos, e uma pequena fração está na forma de grupos di-hidretos ou poli-hidretos; este fato é atribuído ao efeito do bombardeamento de íons sobre os di-hidretos no filme em crescimento 20 .

$O$ uso de uma grade ou a configuração de triodo elimina eficientemente o bombardeamento de íons sobre o filme em crescimento ${ }^{13}$. Na geometria de triodo dois tipos diferentes de arranjo dos eletrodos podem estar envolvidos, como mostra a Figura 3.1.. Na Figura 3.1.a. o terceiro eletrodo contém o substrato sobre o qual o filme é 
crescido. A tensão de polarização é aplicada entre o ânodo e o terceiro eletrodo. A Figura 3.1.b. mostra um arranjo no qual o terceiro eletrodo é uma grade que está aterrada, e o substrato é colocado sobre o ânodo que pode estar submetido a uma tensão de polarização DC em relação à grade; com esta configuração o bombardeamento de íons é até 1000 vezes menor do que na configuração de diodo. Dependendo da tensão de polarização aplicada, ions (especialmente os mais pesados) podem ser extraídos do plasma através de um potencial negativo aplicado ao substrato; assim, íons $\mathrm{SiH}_{3}{ }^{+}$podem alcançar o substrato, ao passo que os mais leves $\mathrm{H}^{+}$param na grade.

$\mathrm{Na}$ ausência de uma grade de triodo, a fração de radicais inicialmente produzidos que alcança o substrato antes de reagir é independente da pressão na câmara do reator. Telas bastante transparentes usadas a uma pequena distância do substrato, com uma rede fina (para impedir inhomogeneidades) podem ser usadas para obter taxas de deposição relativamente elevadas ${ }^{21}$.

O espaçamento entre os eletrodos afeta a qualidade do filme depositado porque ele limita a distância que os radicais viajam antes de alcançar a superfície do filme em crescimento, e ele determina a tensão elétrica de sustentação da descarga através da Lei de Paschen ${ }^{22}$. Esta lei afirma que a tensão de sustentação da descarga é uma função do produto da pressão dos gases envolvidos no processo pelo espaçamento entre os eletrodos. Uma tensão elétrica ligeiramente superior àquela necessária para sustentar a descarga é tipicamente usada para depositar $a$-Si:H de alta qualidade.

Espaçamentos entre 1 e $5 \mathrm{~cm}$ são tipicamente usados na deposição de $a-\mathrm{Si}: \mathrm{H}$; espaçamentos menores do que $1 \mathrm{~cm}$ são indesejáveis porque eles causam uma deposição não-uniforme sobre a área do substrato.

\subsubsection{Tensão de Polarização de Controle}

Em ambas as geometrias de diodo e triodo, uma tensão de polarização aplicada ao substrato em relação ao potencial do plasma pode ter efeitos significativos nas propriedades do filme. Uma vez que a deposição por descarga luminescente é causada principalmente por radicais neutros, a aplicação de uma tensão de polarização não 
afeta o tipo e as propriedades de adesão dos precurscres; ela afeta principalmente as propriedades do filme pelo controle da extensão e da energia dos bombardeamentos de íns e elétrons durante o crescimento do filme. Uma tensão de polarização negativa e moderada, externamente aplicada ou auto-induzida pela geometria assimétrica dos eletrodos, melhora as propriedades elétricas e estruturais dos filmes de $a$-Si:H. Isto ocorre porque o bombardeio moderado de íons, causado por uma tensão de polarização negativa, pode remover sítios de defeitos associados com a ligação $\mathrm{SiH}_{2}{ }^{23.24 .25}$. Além disso, em deposições de descarga DC usando silana pura, um aumento na energia de bombardeamento de íns (principalmente $\mathrm{SiH}_{3}^{+}$) favorece a formação de filmes isotrópicos e homogêneos de alta densidade, correlacionados com a predominância de ligações de mono-hidretos ${ }^{26}$. Contudo, o bombardeamento excessivo de íons e elétrons ${ }^{27}$ podem ter efeitos danosos sobre a qualidade do filme. A seguir, uma breve descrição dos vários efeitos de uma tensão de polarização sobre a taxa de deposição, a densidade de spins, a razão di-hidretos/mono-hidretos e sobre a eficiência na dopagem.
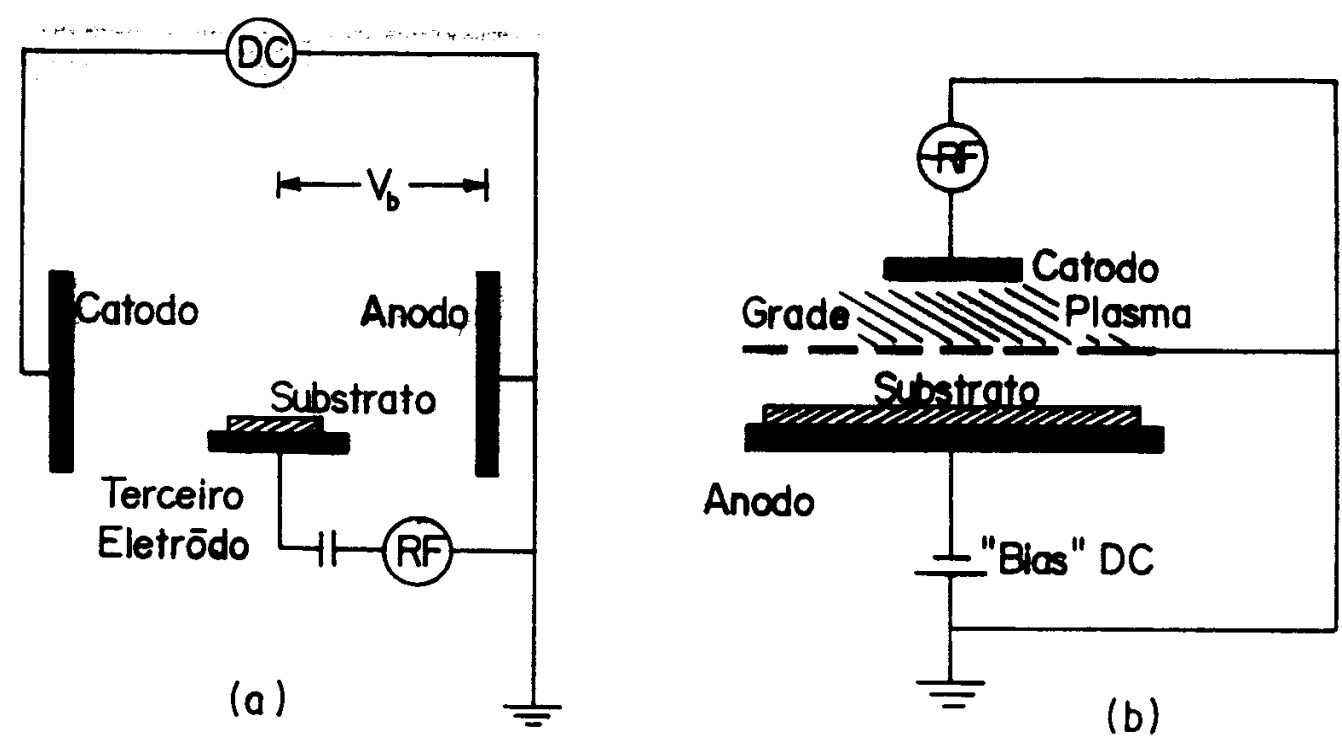

Figura 3.1.: Reator com Geometria de Triodo a) com o Substrato no Terceiro eletrodo: b) com a Grade doTerceiro Eletrodo Aterrada. 
Em um reator de descarga luminescente a RF, simétrico, eletrodos com geometria de diodo usando paredes quentes (hot walls) quando $100 \%$ de silana é usada, a taxa de deposição diminui de $2,3 \mathrm{~nm} / \mathrm{s}$ a $-110 \mathrm{~V}$ DC de polarização para $1,9 \mathrm{~nm} / \mathrm{s}$ quando não há polarização e para $1,5 \mathrm{~nm} / \mathrm{s}$ a $+80 \mathrm{~V}^{28}$. Em um reator com geometria de triodo, a taxa de deposição diminui de $1 \mathrm{~nm} / \mathrm{s}$ a -500 V DC para $0,3 \mathrm{~nm} / \mathrm{s}$ a 0 V29. Quando uma tensão de polarização no substrato negativa em relação ao ânodo é moderada (-50 a $150 \mathrm{~V}$ ), a qualidade do filme melhora. Por outro lado, uma tensão de polarização de $100 \mathrm{~V}$ resulta em um grande aumento na condutividade no escuro e uma diminuição na foto-sensitividade.

O efeito de uma tensão de polarização sobre a densidade de spins depende da densidade de potência da RF em um reator com geometria de diodo. À baixas potências de RF não existe diferença na densidade de spins quando há ou não uma tensão de polarização aplicada; por outro lado, a uma densidade de potência elevada, quando não há uma tensão de polarização a densidade de spins aumenta de um fator 100 em comparação com a situação de baixa densidade de potência, ao passo que a densidade de spins permanece constante na condição de tensão de polarização negativa ${ }^{30}$.

$O$ efeito de uma tensão de polarização sobre o teor de hidrogênio é muito pequeno, e a razão di-hidreto/mono-hidreto aumenta de 0,5 para 0,85 quando a tensão de polarização aumenta de 0 para $+100 \mathrm{~V}$. Além disso, uma tensão de polarização negativa favorece a ligação de mono-hidretos, enquanto que uma tensão de polarização positiva favorece a formação de di-hidretos ${ }^{31}$. Para a geometria de triodo a qualidade do filme (para deposição usando silana) é melhorada por uma tensão de polarização negativa acima do nível de tensão ótimo; um acréscimo adicional na tensão negativa (além de $-200 \mathrm{a}-300 \mathrm{~V}$ ) conduz a deterioração na qualidade do filme; com uma tensão de polarização negativa adequada a incorporação de $\mathrm{SiH}$ é promovida mas a incorporação de $\mathrm{SiH}_{2}$ é deprimida, o que resulta numa melhora na qualidade do filme 29 . 
O efeito de uma tensão de polarização sobre a eficiência na incorporação de boro no filme de $a$-Si:H é bastante significativa. Uma tensão de polarização positiva de 100 $\mathrm{V}$ melhora a condutividade no escuro de amostras de $a$-Si:H dopadas com boro por mais de três ordens de grandeza, comparada com amostras depositadas com nenhuma tensão aplicada ${ }^{31,32}$. No caso de uma tensão de polarização aplicada no substrato, uma tensão positiva melhora a incorporação de fósforo e uma tensão negativa melhora a incorporação de boro ${ }^{33}$.

\subsubsection{O Confinamento do Plasma}

O movimento do elétron no plasma pode ser facilmente influenciado por um campo magnético. Um campo magnético aplicado ao plasma geralmente baixa a temperatura dos elétrons, reduzindo a perda por difusão das partículas carregadas na direção perpendicular ao campo magnético, e isto afeta o teor de di-hidretos e monohidretos nos filmes ${ }^{34}$. O campo magnético ao longo do plasma atua como um filtro de íns; ele pode excluir íons $\mathrm{H}^{+}$leves do substrato que tendem a fazer uma decapagem na superficie do filme depositado; contudo, ions mais pesados podem dirigir-se ao substrato e remover hidrogênio ligado à superfície, especialmente àquele ligado como $\mathrm{Si}-\mathrm{H}_{2}$.

Uma forma de confinar o plasma é colocar os magnetos sob o cátodo, criando um campo magnético entre ele e o ânodo; este processo de deposição é conhecido como método de plasma assistido por magnetron ${ }^{35}$. A difusão de elétrons na direção das paredes é suprimida pelo campo magnético, e isto resulta em um aumento na densidade dos elétrons no plasma, e o consequente aumento na taxa de deposição por causa da elevada concentração de radicais devido ao confinamento de elétrons.

$\mathrm{O}$ confinamento do plasma pode também ser obtido usando-se telas aterradas ao invés de campo magnético. Estas telas confinam a potência da RF. Estudos registram que, plasmas de silana confinados por telas aterradas produzem filmes com estabilidade térmica melhor do que aqueles obtidos com plasma não-confinados, e também aumentam a taxa de deposição significativamente ${ }^{36}$. 


\subsubsection{Contaminação a partir de Impurezas}

Vazamentos de vácuo externos, vazamentos virtuais, e retorno de óleo de bombas na câmara do reator podem introduzir impurezas indesejáveis no filme depositado. Para um sistema de deposição de $a$-Si:H à descarga luminescente, a taxa de vazamento deve ser mantida em um nível abaixo de $1 \times 10^{-5}$ torr-litros/s. Filmes de $a-\mathrm{Si}: \mathrm{H}$ de qualidade eletrônica contém menos do que $5 \times 10^{18} \mathrm{~cm}^{\dagger 3}$ de oxigênio, $5 \times 10^{-18} \mathrm{~cm}^{+3}$ de carbono, e $5 \times 10^{17} \mathrm{~cm}^{43}$ de nitrogênio ${ }^{37}$.

A densidade de defeitos aumenta rapidamente quando a concentração de oxigênio excede $1 \times 10^{20} \mathrm{~cm}^{+3}$, e a concentração de nitrogênio excede $1 \times 10^{19} \mathrm{~cm}^{+3} \mathrm{em}$ amostras de $a$-Si:H não dopadas ${ }^{38}$

\subsection{Os Parâmetros de Deposição}

Porque existem numerosas variações nos projetos de sistemas de deposição a descarga luminescente, os parâmetros de deposição ótimos variam de sistema para sistema, e são geralmente otimizados empiricamente para cada sistema. A densidade de potência de RF, a temperatura do substrato, a pressão na câmara, a concentração dos gases na câmara e o fluxo de gases são os parâmetros de deposição básicos que afetam a qualidade do filme. As propriedades estudadas incluem a taxa de deposição (inerente ao processo), a densidade de defeitos, o teor total de hidrogênio incorporado, o gap de energia, o teor de di-hidretos, a razão di-hidreto/mono-hidreto, a fotocondutividade, e a razão fotocondutividade/condutividade no escuro. Os efeitos dos parâmetros de deposição estão normalmente interrelacionados, e não podem ser expressos como uma simples relação linear.

\subsubsection{Densidade de Potência de RF}

$\mathrm{Na}$ descarga luminescente de mono-silana, a taxa de deposição aumenta monotonicamente com a densidade de potência RF, até que esta seja limitada pelo fluxo do gás ${ }^{28}$. A diluição com hidrogênio (a um fluxo de gás constante) reduz a taxa de deposição ${ }^{30}$. Em deposições usando di-silanas a dependência da taxa de deposição com a potência RF é similar ${ }^{39}$. 
Para filmes a partir de mono-silana, a densidade de spins em função da potência de RF depende das condições de deposição, tais como tensão de polarização nos eletrodos; na condição sem tensão de polarização a densidade de spins aumenta mais de duas ordens de grandeza à medida que a potência de RF é aumentada de um fator $30^{30}$. Para filmes a partir de di-silana, a densidade de spins diminui (à temperatura do substrato entre 200 e 300 C) com o aumento da potência $R F^{30}$.

Em relação ao teor de hidrogênio incorporado nos filmes, existem resultados controversos. De acordo com Knights ${ }^{30}$, o teor de hidrogênio em filmes a partir da mistura silana/argônio, inicialmente cresce e então decresce (permanecendo constante na faixa de 14-17\% a.a.) com o aumento da potência RF (na faixa de 4-30 W). Já de acordo com Ross e Jaklik ${ }^{40}$, o teor total de hidrogênio aumenta de forma monótona com o aumento de potência. Em filmes a partir de di-silana, o teor total de hidrogênio diminui com o aumento da potência $R F$ de acordo com Kumeda ${ }^{41}$, mas aumenta de acordo com Matsuda e colaboradores ${ }^{42}$.

$O$ efeito da potência de RF sobre o gap de energia em filmes depositados a partir de descarga luminescente de mono-silana é inicialmente um aumento no gap e então uma diminuição nesta grandeza, à medida que o nível de potência aumenta ${ }^{43}$. O aumento no gap de energia com a potência RF a níveis de baixa potência é devido ao aumento no teor de hidrogênio, uma vez que o gap aumenta linearmente com o aumento do teor de hidrogênio ${ }^{44}$. À níveis de potência bastante elevados, a formação de silício micro-cristalino causa um decréscimo rápido em ambos, o teor de hidrogênio e o gap óptico+5.

Em filmes a partir de mono-silana, um aumento na densidade de potência aumenta o teor de di-hidretos e a razão di-hidretos/mono-hidretos ${ }^{46}$. Em filmes a partir de di-silana o oposto é verdade ${ }^{47}$.

De acordo com Nishikawa e colaboradores ${ }^{48}$ a condutividade no escuro e a fotocondutividade de filmes a partir de mono-silana inicialmente decrescem e então aumentam de maneira significativa com o aumento da potência RF. Filmes a partir de 
di-silana mostram um aumento e então uma saturação nas condutividades com 0 aumento da potência $\mathrm{RF}^{47}$.

O aumento na densidade de potência também aumenta a estrutura microcolunar $^{23}$. Este tipo de estrutura é indesejável porque ela resulta em propriedades eletrônicas pobres para o filme. $\mathrm{O}$ crescimento de tais microestruturas está associado com a presença de vazios e grupos de poli-silana $\left(\mathrm{SiH}_{2}\right)_{\mathrm{n}}{ }^{26}$.

Para deposição de filmes de $a$-Si:H de alta qualidade usando descarga luminescente a $R F$, a potência é geralmente mantida a um nível levemente acima do mínimo necessário para manter o plasma. Valores típicos, tanto para deposições com mono-silana quanto para di-silana estão na ordem de $0,1 \mathrm{~W} / \mathrm{cm}^{2}$.

\subsubsection{Temperatura do Substrato}

É de concordância geral que a temperatura de deposição ótima para a deposição a partir de descarga luminescente a $\mathrm{RF}$ de $a$-Si:H a partir de mono-silana ou di-silana está entre 200 e $300{ }^{\circ} \mathrm{C}$. A taxa de deposição para filmes a partir de mono-silana é relativamente independente da temperatura do substrato ${ }^{+9}$. Isto significa que os, coeficientes de adesão dos precursores da deposição são relativamente independentes da temperatura do substrato, e a taxa de deposição é limitada pelo suplemento de precursores a partir do plasma. Para filmes a partir de di-silana, a taxa de deposição parece ser constante com o aumento da temperatura do substrato a uma potência de RF elevada, e diminui com o aumento da temperatura do substrato a baixas potências de $\mathrm{RF}^{50}$.

O teor total de hidrogênio diminui com o aumento da temperatura do substrato em filmes depositados a partir de mono-silana ${ }^{30}$ e di-silana ${ }^{40}$, mas o teor de hidrogênio disperso aumenta. De modo similar, o gap óptico de filmes depositados a partir de mono-silana e di-silana ${ }^{51}$ diminui com o aumento da temperatura do substrato.

A densidade de spins diminui com o aumento da temperatura do substrato em ambos os filmes depositados a partir de mono-silana e a partir de di-silana quando a temperatura do substrato é menor do que $300 \mathrm{C}^{52}$. Este fato está provavelmente relacionado ao elevado número de espaços vazios (microvoids) e de ligações de poli- 
hidretos em filmes depositados a temperaturas menores do que $200{ }^{\circ} \mathrm{C}^{53}$. $\mathrm{O}$ número destes espaços vazios diminui com o aumento da temperatura. Resultados mostram que filmes de $a$-Si:H depositados a temperaturas de substrato acima de $250{ }^{\circ} \mathrm{C}$ têm densidades próximas das do silício cristalino ${ }^{54}$.

Em filmes a partir de ambos, di-silana e mono-silana, os teores de di-hidretos e poli-hidretos $^{40}$, e a razão di-hidretos/mono-hidretos ${ }^{46}$ diminuem com o aumento da temperatura do substrato. Em filmes a partir de silana. um aumento na temperatura do substrato diminui o teor do radical $\mathrm{SiH}^{30}$. Filmes depositados a partir de silana com descarga luminescente a RF não mostram ligações com di-hidretos a temperaturas acima de $220^{\circ} \mathrm{C}$. Contudo, filmes crescidos a temperaturas de substrato maiores do que $350{ }^{\circ} \mathrm{C}$ (a temperatura na qual se inicia a saída de hidrogênio do filme) contém hidrogênio insuficiente para passivar as ligações insaturadas. À temperaturas de substrato acima de $550{ }^{\circ} \mathrm{C}$ ( a temperatura na qual se inicia o crescimento de microcristais de silício), os filmes depositados tornam-se policristalinos com nenhum teor de hidrogênio detectável. Em filmes a partir de di-silana uma elevada potência de $\mathrm{RF}$ ou uma temperatura de substrato acima de $250^{\circ} \mathrm{C}$ também elimina ligações com dihidretos.

$\mathrm{Na}$ descarga luminescente de mono-silana, a foto-sensibilidade dos filmes de $a$ $\mathrm{Si}: \mathrm{H}$ diminui com o aumento da temperatura ${ }^{48}$. Ambas, a fotocondutividade e a condutividade no escuro de filmes depositados a partir de di-silana aumentam com o aumento da temperatura ${ }^{47}$.

\subsubsection{A Concentração dos Gases}

Como discutido acima, acredita-se que o radical $\mathrm{SiH}_{3}$ seja o precursor responsável pelos filmes de $a$-Si:H de alta qualidade. Filmes produzidos no regime de depleção de silana, onde existe uma falta de radicais $\mathrm{SiH}$ têm mais defeitos do que aqueles produzidos no regime de excesso de silana. Assim, uma elevada razão entre a concentração de silana e a concentração de gases diluentes deve ser benéfica para a deposição de filmes de elevada qualidade. Uma elevada pressão do gás, um elevado 
fluxo de gases, e uma baixa potência de RF também ajuda a assegurar que a deposição esteja ocorrendo no regime de excesso de silana.

Resultados mostram que a taxa de deposição aumenta quando a concentração de silana aumenta de $10 \%$ a $35 \%$ na deposição a partir de descarga luminescente ${ }^{55}$.

A densidade de spins de filmes a partir de mono-silana diminui agudamente com 0 aumento da concentração de silana em argônio $0^{30}$. $\mathrm{O}$ aumento do peso atômico do gás usado como diluente também aumenta a densidade de defeitos do filme ${ }^{56}$.

$\mathrm{O}$ teor de hidrogênio de filmes de $a$-Si:H a partir de mono-silana aumenta com o aumento na concentração de silana em filmes produzidos por descarga luminescente com $\mathrm{RF}^{30}$. Em filmes a partir de di-silana, o teor total de hidrogênio aumenta com o aumento da concentração de di-silana em hélio

Resultados mostram que uma baixa concentração de silana em argônio conduz a uma alta microestrutura colunar e uma elevada densidade de defeitos, exceto quando uma tensão de polarização negativa é aplicada no substrato ${ }^{23}$.

\subsubsection{Pressão de Deposição}

O efeito da pressão do gás sobre a taxa de deposição no processo de descarga luminescente a partir de ambas mono-silana e di-silana é o mesmo ${ }^{57}$. Na região limitada pelo suprimento de gás, a taxa de deposição é proporcional à pressão; já na região limitada pela potência ela permanece constante. Para a obtenção de filmes de alta qualidade, pressões elevadas e regimes limitados pela potência são indicados; contudo, a pressão usada deve estar abaixo do nível que causa polimerização em fase gasosa, o que resulta na acumulação de pó amarelo dentro do reator; no processo de descarga luminescente a RF com silana pura isto geralmente significa manter a pressão do gás abaixo de 1 torr. A pressão de deposição ótima depende também do espaçamento entre os eletrodos, segundo o enunciado da Lei de Paschen.

Resultados experimentais mostram também que no processo de descarga luminescente a RF e DC para pressões na faixa entre 0,1 e 0,5 torr (isto é, abaixo da pressão que causa a polimerização em fase gasosa) de filmes a partir de mono-silana, o teor total de hidrogênio e o teor de di-hidretos aumentam com o aumento da pressão+0. 
Já a fotocondutividade aumenta com o aumento da pressão em filmes a partir de di-silana diluída com hélio, ao passo que não apenas a fotocondutividade, mas também a condutividade no escuro e a fotossensibilidade diminuem com 0 aumento da pressão quando a di-silana não é diluida.

\subsubsection{Fluxo de Gases}

O fluxo de gases é outro importante parâmetro de deposição primário, mas não é um que possa ser diretamente comparável de um sistema para outro. O fluxo de gases é inversamente relacionado com o tempo de residência, o tempo médio que um uma molécula gasosa permanece no plasma. Este tempo determina a probabilidade da molécula ser dissociada e incorporada no filme em crescimento. Por sua vez, o tempo de residência afeta a depleção do gás; a dados níveis de pressão e densidade de potência, quanto maior for o tempo de residência maior será a depleção do estoque de alimentação dos gases. Esta depleção parece ser um parâmetro crítico que afeta a qualidade do filme; a incorporação de mono-hidretos e a eliminação de di-hidretos parece ser predominante em regimes de fluxo de gases elevados ${ }^{58}$.

Resultados mostram que, à medida que o fluxo de gases aumenta, a depleção diminui e a taxa de deposição aumenta ${ }^{59}$.

\subsubsection{Campo Magnético}

Um campo magnético pode ser usado para confinar o plasma, influenciar a densidade e a temperatura dos elétrons, e modificar o processo de deposição sem alterar outros parâmetros de deposição. Um aumento na intensidade do campo magnético aplicado perpendicularmente à superficie do substrato durante a deposição com descarga luminescente a RF a partir de silana mostrou um aumento no teor de radicais $\mathrm{SiH}$, uma diminuição no teor de radicais $\mathrm{SiH}_{2}$, e um aumento na fotocondutividade ${ }^{60}$.

Sistemas de deposição alternativos usando campos magnéticos incluem o projeto de um campo magnético toroidal para confinar um plasma de silana gerado por um filamento de tungstênio aquecido alimentado por uma corrente DC (descarga toroidal $D C)^{61}$, e a colocação de eletromagnetos atrás do cátodo de RF gerador do plasma de 
silana (método do plasma controlado por magnetron) ${ }^{62}$. No primeiro caso, o objetivo é co-relacionar as propriedades do filme com o fluxo de íons e radicais sobre 0 substrato; já no segundo caso, o objetivo é produzir filmes de $a$-Si:H de alta qualidade a taxas de deposição elevadas (maiores do que $1,5 \mathrm{~nm} / \mathrm{s}$ ).

\subsubsection{Frequência}

Ambas as descargas, AC (principalmente RF) e DC tem sido usadas em deposições de $a$-Si:H de alta qualidade. Embora a descarga luminescente de RF seja usada com mais frequência, não existe evidência conclusiva a respeito de qual método produz filmes de melhor qualidade. A deposição a partir de descarga luminescente a RF é geralmente feita a uma frequência de $13,56 \mathrm{MHz}$; esta é a frequência permitida pelas autoridades internacionais na área de comunicações. A razão pela qual o plasma excitado pela RF é tão popular vem do fato que a rádio-frequência não causa qualquer acúmulo de cargas em isolantes ou superfícies isoladas eletricamente dentro do reator, e além disso, acredita-se que a RF seja mais eficiente do que a excitação DC na promoção da ionização e na manutenção da descarga. À baixas frequências $\mathrm{AC}$, a descarga luminescente é descontínua, e os eletrodos sucessivamente tomam polaridades opostas. À frequências acima de $1 \mathrm{MHz}$, a descarga pode ser mantida quase que continuamente, e os ions no plasma não podem seguir instantaneamente $o$ campo de excitação devido à sua massa elevada; consequentemente, apenas elétrons podem responder instantaneamente ao campo de RF e ganhar energia suficiente para ionizar o gás ${ }^{63}$.

Estudos variando a frequência na faixa de 25 a $150 \mathrm{MHz}$ mostram que a taxa de deposição aumenta até alcançar um máximo em torno de $70 \mathrm{MHz}$, e neste ponto ela é cerca de quatro vezes maior do que quando a frequência de $13,56 \mathrm{MHz}^{\text {é usada }}{ }^{64}$; os parâmetros que medem a qualidade do filme usando $70 \mathrm{MHz}$ foram comparáveis àqueles usando frequências mais baixas. Acima de $70 \mathrm{MHz}$ a taxa de deposição cai de maneira drástica. A explicação para estes fatos é que a $70 \mathrm{MHz}$ o plasma é autoconfinado, eliminando a necessidade de outros tipos de confinamento. 
Micro-ondas com frequência de $2,45 \mathrm{GHz}$ são também usadas na decomposição na deposição a plasma de $a-\mathrm{Si}: \mathrm{H}^{65}$. Na faixa de frequência de micro-ondas, mesmo os elétrons não podem responder em fase com a alta frequência do campo elétrico. Isto resulta em baixas eficiências de transferência de energia do campo elétrico para o plasma, e consequentemente, uma maior potência aplicada é necessária para manter o plasma do que aquela usada em descargas RF; este aumento de potência afeta tanto a temperatura do gás como a temperatura do substrato em detrimento da qualidade do filme depositado. A ressonância ciclotrônica eletrônica (ECR) tem sido usada para melhorar a transferência de energia no plasma gerado por micro-ondas, e isto resulta em uma elevada taxa de deposição em filmes de $a$-Si:H.

Descreveremos a seguir, passo a passo, as etapas da construção do reator de descarga luminescente a $60 \mathrm{~Hz}$.

\subsection{Câmara de Deposição}

A câmara de deposição é o núcleo de todo o sistema de deposição, é onde ocorre todo o processo físico-químico envolvido na obtenção dos filmes de $a-\mathrm{Si}: \mathrm{H}$. Desta forma, o formato, as dimensões, e os materiais envolvidos na construção da câmara são de fundamental importância para a obtenção de filmes de qualidade eletrônica.

\subsubsection{Parte Externa}

No processo de deposição utilizamos um pré-vácuo da ordem de $10^{-6}$ torr para eliminar ou reduzir impurezas indesejáveis à qualidade do filme, como por exemplo carbono e oxigênio. Isto obriga a que utilizemos aço inoxidável como o material de construção da câmara. A característica principal deste material é que ele possui em sua composição química, uma quantidade muito pequena de carbono; constituindo-se essencialmente de uma liga de átomos de ferro, níquel e cromo. Nesta liga, os átomos de carbono são residuais, ao contrário dos aços comuns, onde estes são encontrados numa proporção de até $2 \%$ em átomos. Isto faz com que haja poucos átomos de 
carbono adsorvidos nas superficies do aço-inoxidável, e assim seja mais fácil retirá-los da câmara.

A otimização do uso dos gases sugere que o volume da câmara seja o menor possivel, e que estes fiquem concentrados na região dos eletrodos. Por motivo de facilidade, em nosso sistema nós adaptamos uma câmara normalmente usada para deposição de contatos metálicos, e usamo-la para os nossos objetivos. O volume desta câmara é cerca de 30 litros, não muito pequeno para os nossos objetivos iniciais, porém ainda adequado para nosso estudo. As adaptações feitas foram a colocação de duas janelas laterais, perpendiculares entre si, para a visualização do processo e futuras medidas in situ do crescimento e propriedades do plasma. Uma das janelas tem dimensão $15 \mathrm{~cm}$, e a outra mede $4 \mathrm{~cm}$; para a construção de ambas, foram soldadas flanges adequadas ao vácuo desejado; ambas as flanges têm dimensões especialmente projetadas para nosso sistema, e em ambas as janelas foram usados vidros comuns. Um desenho da câmara de deposição pode ser visto na Figura 3.2..

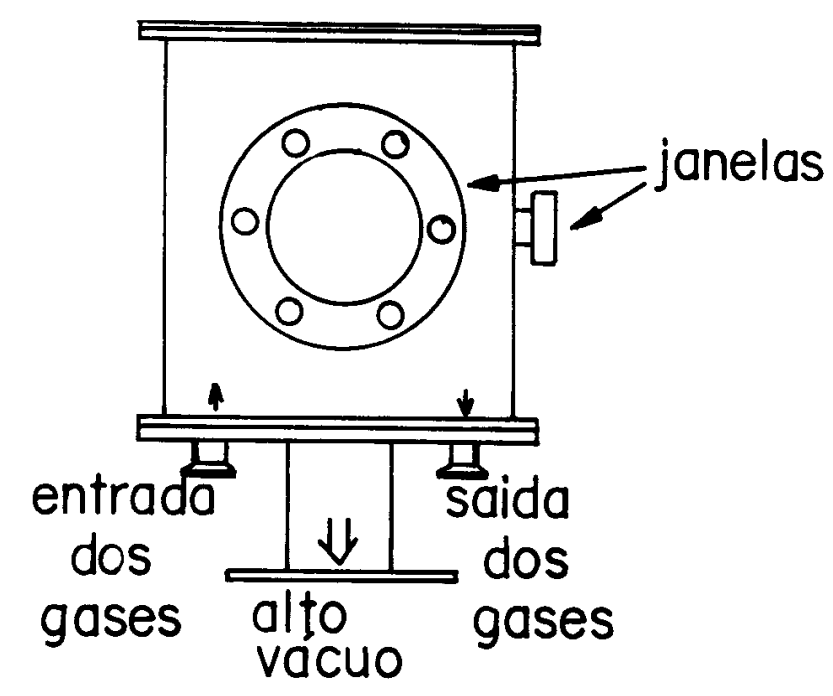

Fig. 3.2. Vista Externa da Câmara de Deposição.

As conexões elétricas e aquelas para a tubulação do fluxo de gases foram todas feitas na tampa inferior da câmara; a fim de que nossos objetivos fossem alcançados, 
necessitamos projetar os seguintes alimentadores (feed-throughs) para esta tampa inferior:

i) um alimentador de entrada de gases usados nas deposições;

ii) um alimentador para o medidor de alto-vácuo (modelo Penning) e baixas pressões (baratron);

iii) um alimentador para a saída de gases usados nas deposições;

iv) um alimentador para a entrada de um fluxo de $\mathrm{N}_{2}$ seco, usado para quebrar 0 vácuo dentro da câmara após cada deposição;

v) um alimentador para um dos eletrodos do transformador usado com fonte de tensão para produção da descarga necessária para criar o plasma;

vi) um alimentador para os dois eletrodos ligados ao conjunto de resistências usadas como aquecedor do porta-substrato;

vii) um alimentador para o segundo eletrodo do transformador descrito acima; neste alimentador também estão conectados dois eletrodos usados para fornecer aos eletrodos internos uma tensão de polarização DC.

viii) por fim, um último alimentador para o termopar usado na medida da temperatura do porta-substrato.

Um desenho desta tampa inferior, com o posicionamento de cada alimentador está mostrado na Figura 3.3.. Todos os alimentadores são projetados segundo a norma para componentes de vácuo; aqueles projetados para a entrada e saída de gases, e para os eletrodos dos transformadores são de dimensão KF-25, enquanto que os demais são KF-16.

Os alimentadores para a entrada e saída de gases são semelhantes, e ambos estão ligados externamente à tubos de aço inoxidável. $\mathrm{O}$ alimentador para a medida de alto e baixo-vácuo tem duas entradas, uma para o gauge Penning (alto-vácuo) e outra para o baratron (baixas pressões). $\mathrm{O}$ alimentador para $\mathrm{N}_{2}$ seco é tal que na sua extremidade está ligada uma válvula do tipo agulha usada para controlar o fluxo do gás. Os alimentadores usados para ligar o transformador às grades é constuído de forma que no centro deles é colocado um fio de cobre de $\cong 2 \mathrm{~mm}$ de diâmetro, usado 
como condutor elétrico; além disto, um destes dois alimentadores contém outros dois fios de cobre de diâmetro $\cong 0,3 \mathrm{~mm}$, usados como contato da fonte de alimentação DC para fornecer a tensão de polarização. Por fim, temos 0 alimentador usado tanto para levar os fios do termopar, quanto para levar os fios ligados nos terminais da resistência do aquecedor do porta-substrato. Todos estes alimentadores foram feitos de aço inoxidável, pelas mesmas razões descritas acima, e naqueles em que havia a necessidade da passagem de fios condutores foram usadas guias internas de acrílico perfuradas, por onde tais fios pudessem passar. Além disso, todos os alimentadores foram preenchidos com uma resina epóxi especial, responsável pela isolação elétrica (no caso onde houvessem fios) e pela manutenção do vácuo dentro da câmara. Todos os alimentadores descritos acima foram projetados e construídos por nós mesmos.

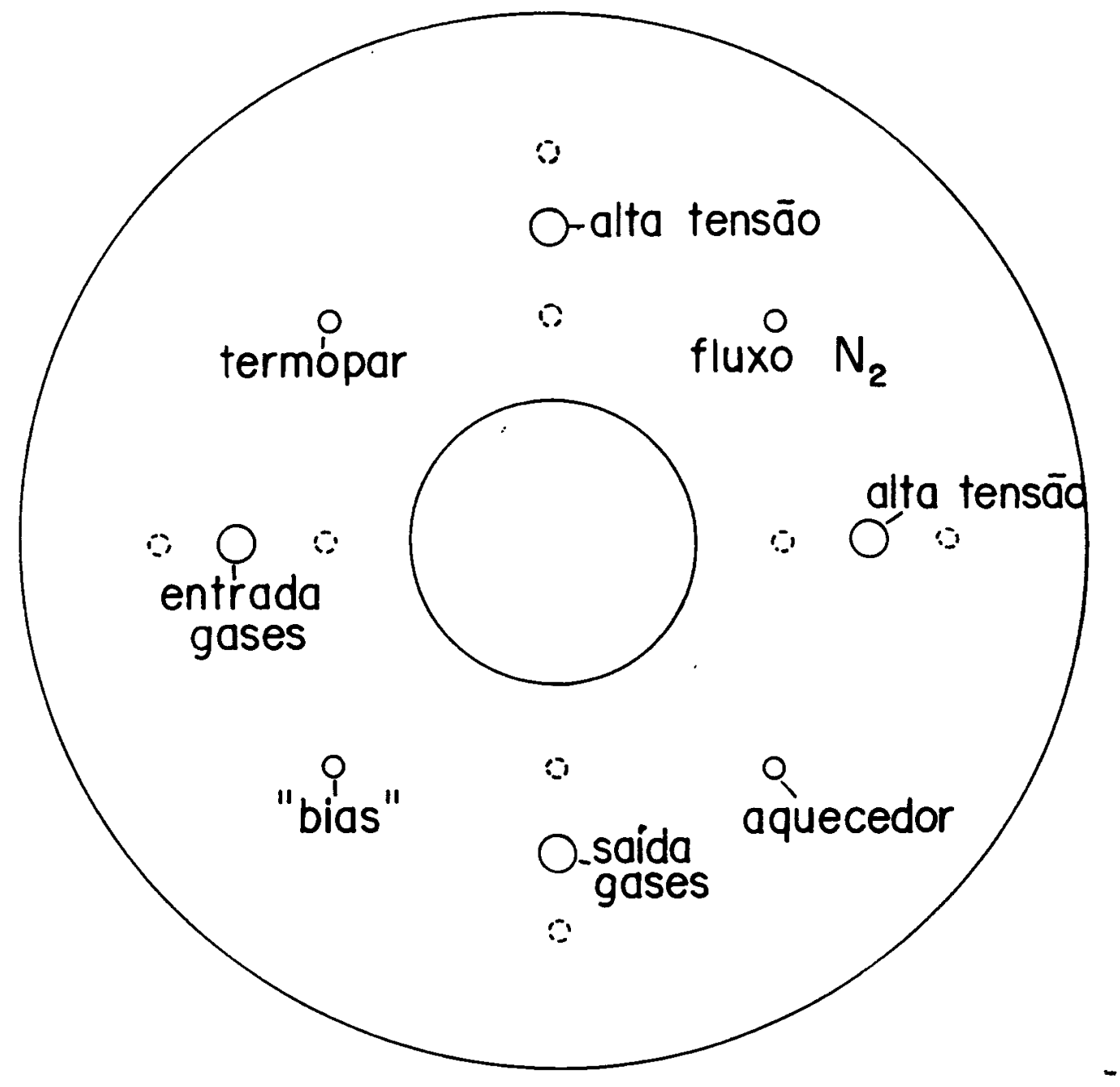

Fig. 3.3. Esquema da Tampa Inferior da Câmara de Deposição. 


\subsubsection{Parte Interna}

Todos os componentes internos à câmara de deposição foram construidos de aço inoxidável, pelas mesmas razões explicadas acima. Os componentes internos à câmara são:

i) quatro postes usados para posicionar o porta-substrato na altura adequada para a deposição;

ii) quatro postes menores usados para posicionar os eletrodos internos na altura da janela maior da câmara;

iii) duas grades cilíndricas, de diâmetro $15 \mathrm{~cm}$ e espessura $1 \mathrm{~mm}$, perfuradas homogeneamente com furos de $0,5 \mathrm{~cm}$ de diâmetro; um desenho destas grades está mostrado na Figura 3.4.;

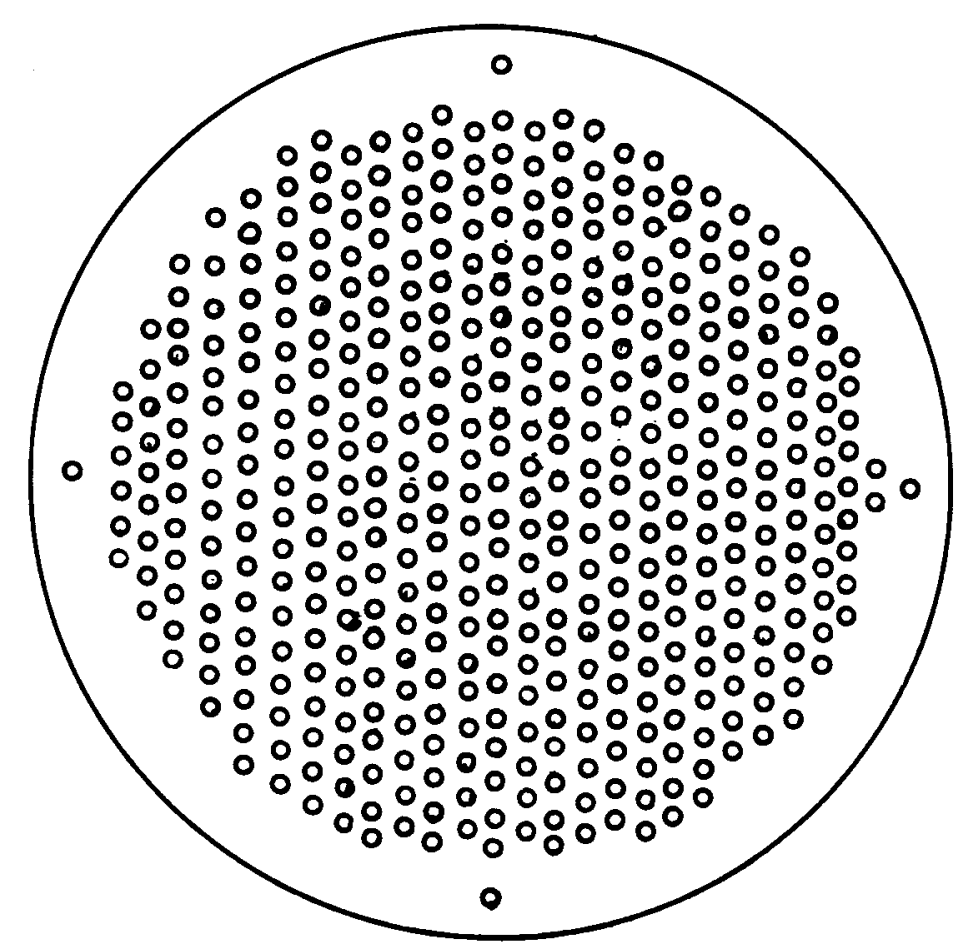

Fig. 3.4. Esquema das Grades usadas como Eletrodos Ativos no Processo de Deposição.

iii) um porta-substrato especialmente projetado para este sistema, com possibilidade de receber uma resistência em espiral adequada para vácuo, usada para aquecê-lo; um desenho do porta-substrato está mostrado na Figura 3.5.; 


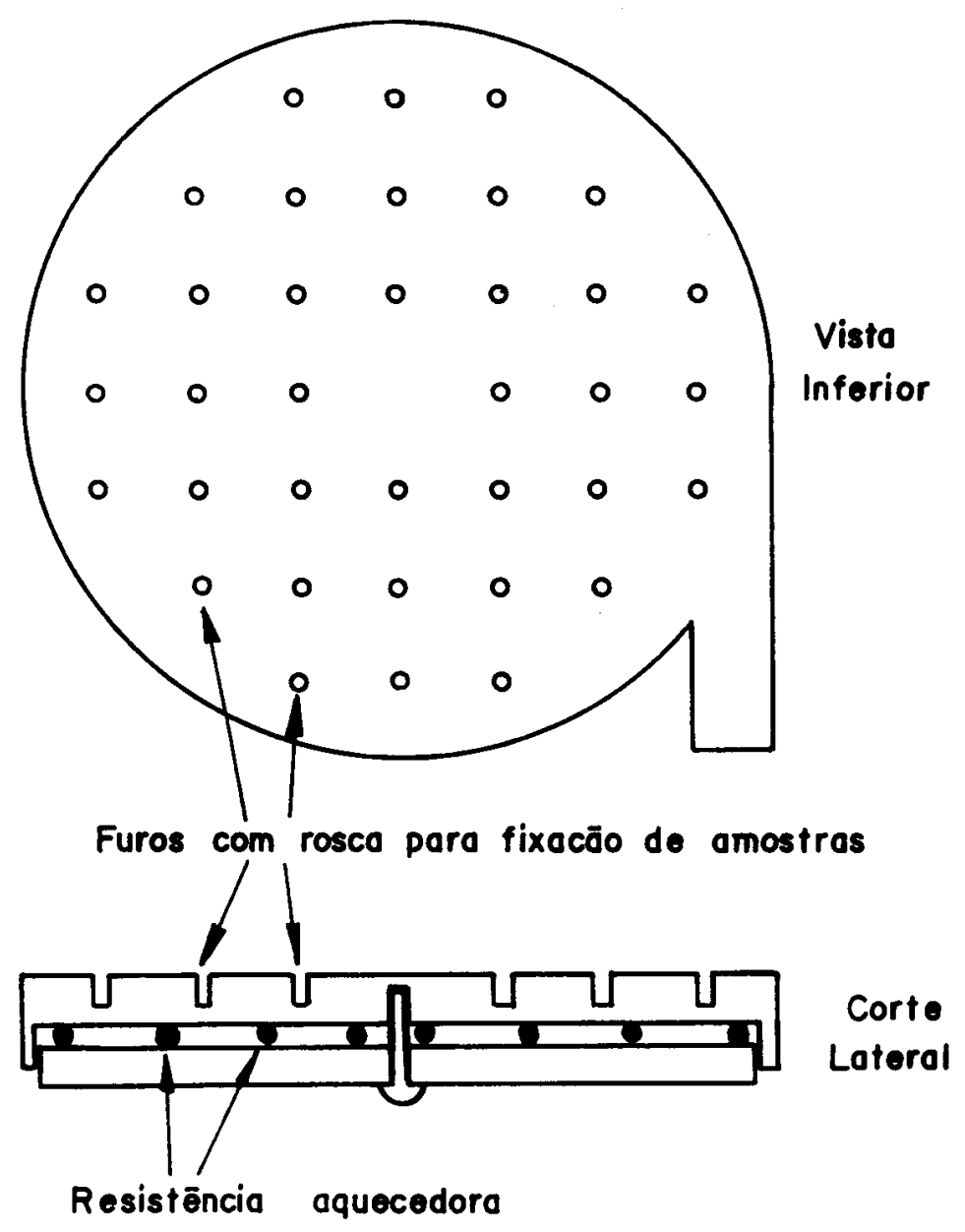

Fig. 3.5. Esquema do Porta-Substrato usado na Deposição.

iv) anéis de teflon, usados como isolantes elétricos entre os diversos componentes metálicos descritos acima; projetamos também suportes de teflon sobre os quais a primeira grade cilindrica é apoiada.

Os postes de aço inoxidável são unidos à tampa inferior da câmara mediante parafusos Allen sem cabeça; furos adequados são feitos tanto na tampa inferior da câmara, quanto nos postes. Desta mesma forma são unidos cada suporte de teflon ao seu respectivo poste. A primeira grade é então apoiada sobre este suporte, com um conjunto de anéis de teflon de cerca de $2 \mathrm{~cm}$ de altura separando-a da segunda grade. Sobre a segunda grade um novo conjunto de anéis de teflon é colocado, novamente com cerca de $2 \mathrm{~cm}$ de espaçamento. Sobre estes anéis é colocado então o portasubstrato. Um esquema dos componentes internos da câmara de deposição, na forma como estão montados no sistema, está mostrado na Figura 3.6.. 


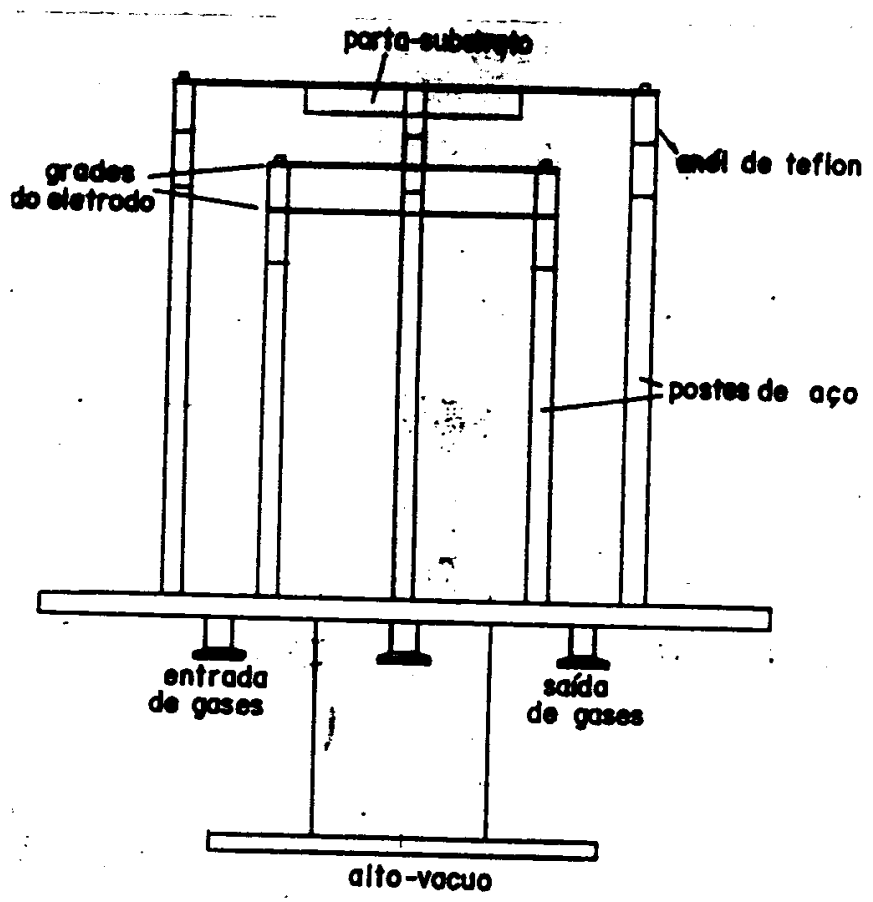

Fig. 3.6. Vista Interna da Câmara de Deposição.

\subsection{Linha de Gases}

A linha de gases é toda ela feita de tubos de aço inoxidável, pelas mesmas razões expostas acima. Da forma como a linha foi projetada em nosso sistema, ela pode ser dividida em duas regiões distintas:

i) uma região entre a câmara de deposição e uma câmara de mistura;

ii) e uma região entre a câmara de mistura e os cilindros dos gases.

Da câmara de deposição até a câmara de mistura toda a tubulação tem diâmetro de $2,54 \mathrm{~cm}$. Até chegar à câmara de mistura, a tubulação sofre uma série de curvas de $90^{\circ}$; em cada ponto de curva uma parte da tubulação é soldada à outra, com o cuidado de nenhum ponto de vazamento ser deixado nos entroncamentos.

Na câmara de mistura a linha de gases é dividida em seis linhas auxiliares, cada uma responsável pelo fluxo de um tipo de gás. O nosso sistema foi projetado para a deposição de $a-\mathrm{Si}: \mathrm{H}$ intrínseco, dopado com excesso de elétrons (tipo $n$ ), dopado com excesso de buracos (tipo $p$ ) e $a-\mathrm{SiC}: \mathrm{H}$. Assim, os seguintes gases estão ligados às linhas:

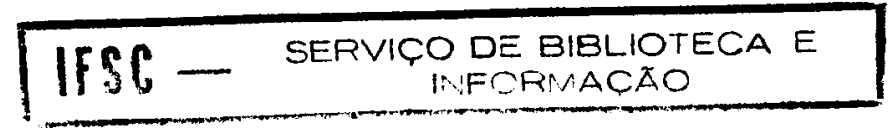


i) silana $\left(\mathrm{SiH}_{4}\right)$;

ii) hidrogênio $\left(\mathrm{H}_{2}\right)$;

iii) fosfina $\left(\mathrm{PH}_{3}\right)$;

iv) diborana $\left(\mathrm{B}_{2} \mathrm{H}_{6}\right)$;

v) metano $\left(\mathrm{CH}_{4}\right)$;

vi) e argônio (Ar).

Todos os gases têm pureza compativel com a obtenção de materiais de qualidade eletrônica. $\mathrm{Na}$ deposição de $a$-Si:H intrínseco usamos silana, e eventualmente uma mistura de silana e hidrogênio. Quando $a$-Si:H tipo $n$ é desejado, usamos uma mistura de silana com fosfina, ao passo que uma mistura de silana com diborana é feita quando $a$-Si:H tipo p é desejado. Misturas de silana com metano são feitas quando desejamos obter ligas de $a-\mathrm{SiC}: \mathrm{H}$. O cilindro de argônio é ligado ao sistema caso seja desejável usar este gás para realizar uma limpeza do sistema com um plasma de gás raro não reativo. A câmara de mistura é projetada exatamente para homogeneizar a mistura de gases antes dela ser introduzida na câmara de deposição para formar o plasma e as reações fisicas e químicas que dão origem à formação dos filmes. Um desenho da câmara de mistura é mostrado na Figura 3.7..

NW 25-KF

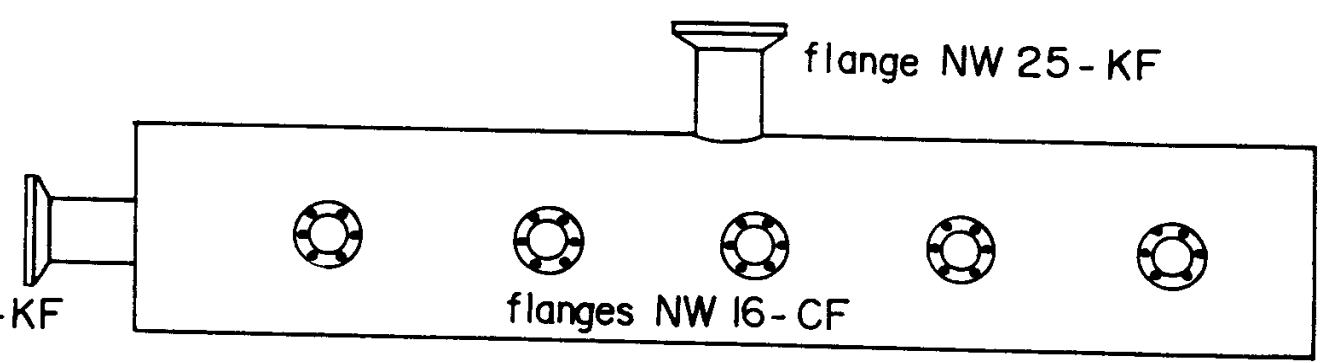

Fig. 3.7. Esquema da Câmara de Mistura

Da câmara de mistura até os cilindros de gases cada tubo passa a ter diâmetro de $6,3 \mathrm{~mm}$. Antes de chegar até os cilindros, cada tubo passa por uma válvula agulha responsável pelo controle fino do fluxo de gases. A ligação da válvula agulha com cada tubo é feita através de conexões do tipo CF-16, especiais para vácuo, soldadas em 
cada extremidade dos tubos. Anéis de cobre são usadas nestas conexões para garantir que 0 selo do vácuo seja mantido. Após a junção de toda a tubulação, desde os cilindros dos gases até a câmara de deposição, um detector de vazamentos (leak detector) é passado no sistema para garantir que não exista qualquer tipo de problemas com o vácuo ao longo de todo o sistema.

\subsection{Componentes Elétricos}

Uma série de componentes elétricos é necessário no sistema para a formação do plasma, auxílio na deposição e controle do processo. Descreveremos a seguir cada um dos componentes usados em nosso sistema.

\subsubsection{Geração do Plasma}

Para a formação do plasma, nós usamos como fonte de tensão um transformador AC $-60 \mathrm{~Hz}$ com capacidade de $3000 \mathrm{~V}$. É ele o responsável pela geração do plasma dentro da câmara de deposição. Este transformador está ligado diretamente às grades descritas acima.

Obviamente, não são necessários todos os $3000 \mathrm{~V}$ que o transformador pode fornecer para que o plasma de silana seja formado. Para que pudéssemos ter controle sobre a tensão aplicada para formar o plasma, um variac foi adicionado em série ao transformador; com ele foi possível obter uma variação de $0-3000 \mathrm{~V}$ sobre a tensão de saída do transformador. Como veremos na Seção 5 deste trabalho, a tensão de trabalho não superou $500 \mathrm{~V}$. Além disso, uma resistência de $5 \mathrm{k} \Omega$ foi adicionada em série ao transformador para que fosse possível medir a queda de tensão no plasma, e assim podermos ter uma idéia do valor da corrente no plasma. Este resultado é importante na determinação da potência total necessária para gerar o plasma.

\subsubsection{Auxílio na Deposição}

É comum em reatores com os mesmos objetivos do nosso disporem de sistemas auxiliares para a excitação do plasma. Uma das idéias largamente usadas em reatores de descarga luminescente é a utilização de uma tensão de polarização DC para auxiliar as componentes moleculares do plasma a depositarem-se sobre o substrato aquecido; 
como foi descrito na Seção 3.3.2., a utilização desta tensão de poarização pode melhorar tanto as propriedades do filme como a eficiência do processo, elevando a taxa de deposição. Neste sentido, nós projetamos uma fonte de tensão DC, que pudesse trabalhar na faixa de -100 até $+100 \mathrm{~V}$, valores estes comumente usados em reatores similares. Esta fonte de tensão não apresenta quaisquer novidades; trata-se de um dispositivo usado apenas para converter a tensão alternada da rede elétrica em uma tensão contínua que possa ser variada de $-100 \mathrm{a}+100 \mathrm{~V}$.

\subsubsection{Controle da Temperatura de Deposição}

A temperatura do substrato é sem dúvida um dos principais parâmetros envolvidos no processo de deposição de filmes finos por descarga luminescente. $O$ seu controle é então de fundamental importância para a obtenção de filmes de boa qualidade. Para suprir o porta-substrato de temperaturas de trabalho (da ordem de 200 ${ }^{\circ} \mathrm{C}$ ), nós usamos uma resistência elétrica especial para uso em vácuo, como mostrado acima. Necessitamos então de uma fonte de alimentação para gerar corrente elétrica suficiente para que esta resistência alcançasse tal temperatura. Para este objetivo, não é necessário o uso de uma tensão $\mathrm{DC}$, já que a resistência trabalha adequadamente com tensões AC. Usamos então um variac comum, ligado diretamente à rede elétrica; o variac permite que, ao variarmos a tensão elétrica entre os terminais da resistência, a corrente elétrica que passa por ela possa também ser controlada. Assim, conseguimos uma relação unívoca entre a corrente aplicada na resistência e a temperatura final do porta-substrato.

É sabido que qualquer sistema tem uma determinada inércia térmica, isto é, demora um determinado tempo para aquecer quando submetido a uma transferência de calor por contato. Sabendo disto, nós levantamos uma curva de resposta da temperatura do substrato em função do tempo; isto foi feito para várias correntes aplicadas na resistência, de forma que no final fosse possivel ter uma boa idéia de quanto tempo o porta-substrato demora para atingir a temperatura de trabalho, e qual a corrente elétrica era suficiente para chegar a determinada temperatura. A medida da 


\subsubsection{Medidores de Pressão}

Em termos da medida de pressão, duas são as necessidades existentes em nosso sistema:

i) a medida de alto-vácuo, feita no estágio anterior à deposição, quando um prévácuo da ordem de $10^{-6}$ torr é feito dentro da câmara de deposição;

ii) a medida de baixa pressão (alguns mili-torr), feita quando do processo de deposição, quando os gases envolvidos são inseridos na câmara.

Para a medida de alto-vácuo, usamos um medidor padrão do tipo Penning comercial da marca Edwards, Modelo CP25EK. A cabeça do medidor está inserida na câmara através do alimentador especialmente desenhado para este fim. Eles estão em contato através de uma conexão do tipo KF-25, especial para vácuo. A cabeça está ligada à parte eletrônica do medidor por cabos coaxiais.

Por sua vez, para a medida de baixas pressões, usamos um medidor comercial do tipo baratron da marca MKS, Modelo 122A. O mesmo alimentador é usado para a conexão deste medidor; o contato entre o alimentador e o baratron é feita por uma conexão do tipo KF-16.

\subsubsection{Medidor de Temperatura}

Para medir a temperatura do substrato nós usamos um termopar de ChromelAlumel comercial ligado a um mili-voltímetro.

O termopar de Chromel-Alumel foi escolhido por que ele é adequado para a faixa de temperatura na qual estamos interessados em trabalhar.

\subsubsection{Medidor da Tensão de Polarização}

Como colocado acima, a faixa de variação da tensão de polarização está entre 100 e $+100 \mathrm{~V}$. Para medir esta ordem de grandeza de tensão DC nós usamos um medidor analógico, similar àquele associado ao termopar, obviamente levando em conta a faixa de tensão a ser medida por ele. 


\subsubsection{Medidor do Fluxo de Gases}

A medida do fluxo de gases que entram na câmara foi feita de maneira indireta, já que não dispomos em nosso sistema de um medidor de fluxo comercial do tipo medidor de fluxo de massa. Assim, para estimar o fluxo nós medimos a variação da pressão dentro da câmara com 0 tempo, mantendo o registro da bomba mecânica conectada ao alimentador da saída de gases da câmara fechado. Admitindo que os gases envolvidos na deposição possam ser considerados ideais, obtemos uma relação entre a taxa de variação de pressão e o fluxo de gases.

\subsection{Componentes de Vácuo}

Como já foi discutido acima, antes da deposição propriamente dita, é necessário efetuar vácuo no sistema, levando-o a uma pressão da ordem de 10-6 torr. Para chegar a este valor, nós optamos por utilizar uma bomba do tipo difusora; para alcançar o vácuo desejado em um tempo suficientemente curto, nós usamos uma bomba difusora com capacidade de 800 1/s, refrigerada a água. Em nosso sistema, como componente da bomba difusora, nós usamos uma bomba mecânica Edwards Modelo E2M25 para o pré-vácuo. Uma válvula do tipo gaveta é usada para isolar a câmara de deposição da bomba difusora. Para aumentar a eficiência deste sistema de vácuo, uma armadilha à base de nitrogênio líquido foi projetado para ser colocado entre a válvula gaveta e a câmara de deposicão. Além de melhorar o vácuo do sistema, esta armadilha impede que o óleo de silicone usado na bomba difusora suba até a câmara de deposicão, caso algum problema com o sistema de refrigeracão aconteça na bomba difusora.

Para o nosso sistema foi ainda projetado o uso de uma outra bomba mecânica, usada exclusivamente para evacuar a câmara logo após a deposição. A presença desta segunda bomba mecânica ajuda a preservar a bomba difusora do contato com os gases usados na deposição. Um contato destes gases com o óleo de silicone da bomba difusora poderia diminuir o seu tempo de uso. 


\subsection{Preparação dos Substratos para a Deposição}

Muito cuidado deve ser tomado com os substratos usados para a produção de amostras. Qualquer contato manual, ou sujeira sobre os substratos podem prejudicar o produto final, deteriorando as propriedades desejadas pela presença de gordura ou impurezas que prejudiquem a correta deposição dos filmes.

Assim, um procedimento padrão é utilizado, visando garantir a limpeza do substrato, antes de colocá-lo na câmara para a deposição. Tal procedimento serve tanto para substratos de vidro, como para os de silício policristalino, ambos usados para a obtenção dos filmes.

O procedimento, passo a passo, é descrito a seguir:

i) o primeiro passo é lavar o substrato com água destilada;

ii) a seguir, introduzimos o substrato em um béquer com trigliceriglicol levemente aquecido ( $\mathrm{em}$ torno de $40^{\circ} \mathrm{C}$ ), para reduzir (e se possivel eliminar) gorduras presentes sobre ele;

iii) novamente o substrato é lavado com água destilada;

iv) a seguir, o substrato é lavado com metanol;

v) novamente o substrato é lavado com água destilada;

vi) por fim, o substrato é seco com um sopro de nitrogênio seco ultra-puro.

Após a limpeza, os substratos são fixados no porta-substrato com grampos metálicos, que por sua vez são presos a ele por parafusos.

Todo o procedimento de limpeza e colocação dos substratos na câmara de deposição é feito com o operador vestido com luvas limpas e manuseando as amostras com pinças adequadas.

\subsection{Operação do Reator}

Uma vista completa do reator por nós projetado está mostrado na Figura 3.9.. $\mathrm{Na}$ Figura 3.10. podemos ver uma vista esquemática, privilegiando o painel de operações do reator. 


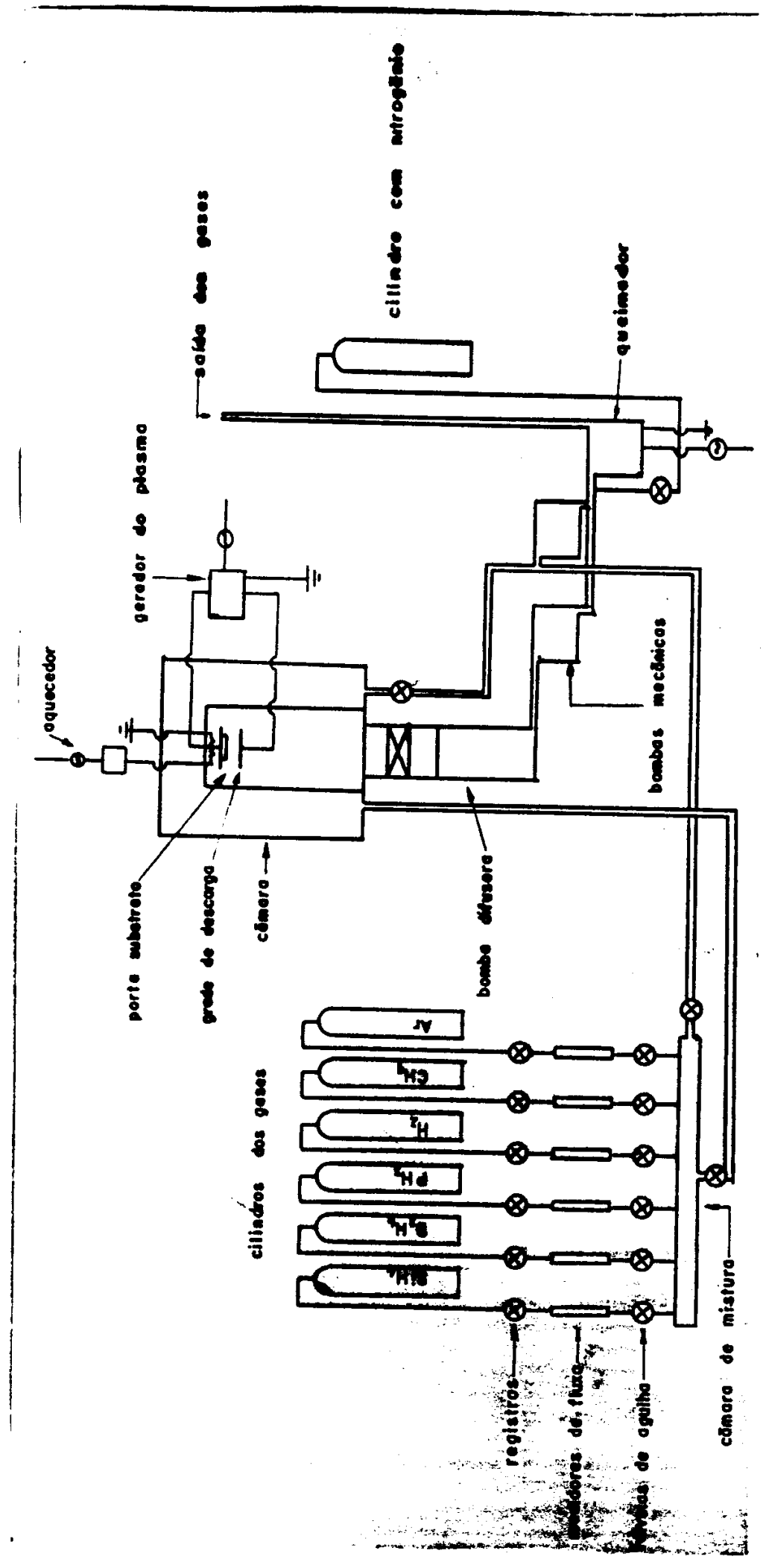

Fig. 3.9. Vista Completa do Reator de Descsarga Luminescente a $60 \mathrm{~Hz}$ usado para a Produção de Filmes de $a-\mathrm{Si}: \mathrm{H}$. 


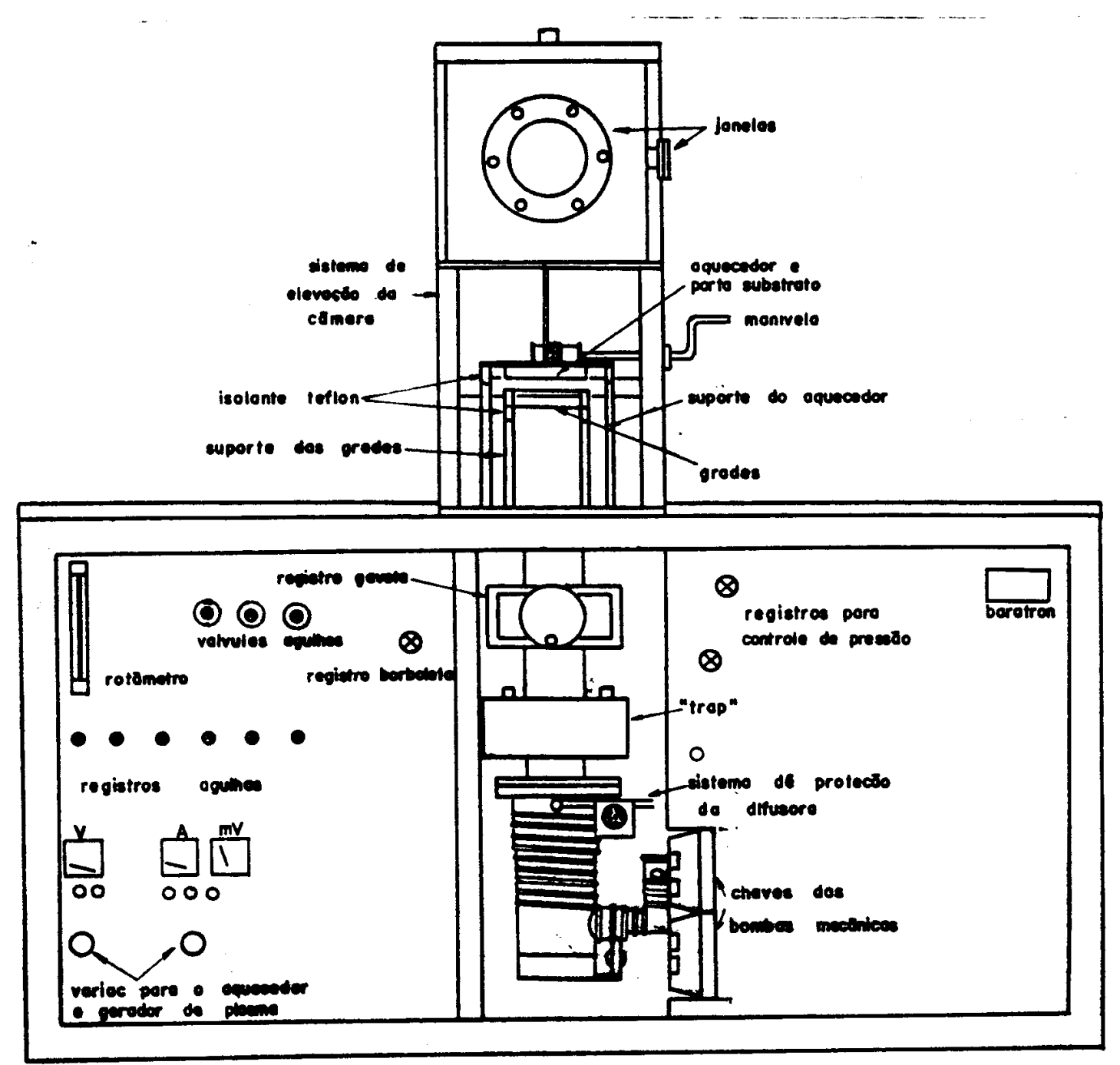

Fig. 3.10. Vista Esquemática do Reator de Descarga Luminescente a $60 \mathrm{~Hz}$. com Destaque para o Painel de Operações.

A sua operação é bastante similar à de qualquer sistema onde vácuo esteja envolvido. Inicialmente é necessário atingir um vácuo da ordem de $10^{-6}$ torr, para garantir que a câmara de deposição esteja livre de possíveis contaminantes, tais como átomos de oxigênio e carbono, e vapores proveniented da água e solventes usados. Isto é feito colocando em operação a bomba mecânica auxiliar da bomba difusora até que um vácuo da ordem de $10^{-6}$ torr seja atingido, e após isto, ligando a resistência da bomba difusora. Após um tempo de cerca de 24 horas o sistema atinge o vácuo 
desejado: isto significa que para uma deposição o sistema deve ser preparado com um dia de antecedência. Para adiantar o processo, no mesmo dia de operação da bomba difusora, a resistência usada para aquecer o porta-substrato é ligada na tensão adequada para fornecer a temperatura desejada.

Na deposição propriamente dita, seguimos a seguinte ordem de abertura de válvulas:

i) abrimos as válvulas dos gases envolvidos na deposição;

ii) abrimos a válvula agulha do painel central do reator, permitindo que os gases possam adentrar a câmara de mistura;

iii) abrimos a válvula borboleta, permitindo que os gases possam chegar até a câmara de deposição.

A pressão dos gases para a deposição é então controlada através do manuseio da válvula agulha, da válvula borboleta, e de uma outra válvula do tipo sanfonada, colocada na saída da câmara, em direção à bomba mecânica usada na exaustão dos gases.

A seguir, aplicamos a tensão $\mathrm{AC}$ entre as grades, de tal forma a gerar o plasma e iniciar o processo de deposição. A tensão no transformador é controlada de forma a gerar um plasma bastante tênue, garantindo que tal tensão seja apenas levemente superior àquela necessária para criar o plasma, segundo indicação da Lei de Paschen.

A tensão no transformador é mantida durante todo o tempo desejado para a deposição do filme. O tempo de deposição é o parâmetro que nós usamos para estimar a espessura do filme; até um tempo de 4 horas de deposição existe uma relação linear entre o tempo e a espessura final dos filmes. Tempos da ordem de quatro horas determinam filmes de cerca de $1 \mu \mathrm{m}$ de espessura.

Após o tempo desejado, a tensão no transformador é desligada, e as válvulas de entrada de gases todas fechadas. Abrimos então a válvula sanfonada e o sistema está pronto para fazer a evacuação da câmara. Desligamos também a tensão na resistência, e deixamos o porta-substrato resfriar por inércia térmica. Quando o porta-substrato atinge a temperatura ambiente o reator é aberto, e as amostras são retiradas dele. Neste 
ponto, as amostras estão prontas para a caracterização segundo as técnicas discutidas a seguir.

\subsection{Caracterização do Reator}

Vários são os parâmetros de deposição que interferem nas propriedades finais dos filmes de $a$-Si:H, como foi descrito na Seção 3.3 deste trabalho. Entre eles podemos citar a pressão de deposição, a temperatura do substrato, o fluxo dos gases, a potência usada para excitar o plasma, a utilização de uma tensão de polarização, a presença de um campo magnético de confinamento e a frequência de excitação do plasma. Assim, para caracterizar o reator de descarga luminescente a $60 \mathrm{~Hz}$ nós procuramos variar cada um destes parâmetros para a obtenção de condições nas quais ele pudesse fornecer filmes de $a$-Si:H de boa qualidade.

Em relação à frequência, este trabalho é todo dedicado ao estudo da deposição de $a$-Si:H usando $60 \mathrm{~Hz}$ como frequência de excitação. Todos os nossos resultados são comparados com propriedades de filmes depositados de forma convencional, ou seja, usando rádio-frequência, normalmente a $13,56 \mathrm{MHz}$.

Em relação ao campo magnético para confinamento do plasma, a Seção 3.2 . mostra que em nosso sistema de deposição não existem bobinas onde seria aplicada uma corrente para produzir o campo magnético estático. Desta forma, este parâmetro não será considerado nesta análise.

Nosso sistema de deposição prevê a aplicação de uma tensão de polarização, como pode ser visto na Seção 3.2.. Em algumas deposições nós usamos tensão de polarização de até $\pm 100 \mathrm{~V}$; porém, como em todos estes casos os filmes mostram baixa foto-sensibilidade, concluímos que uma tensão de polarização conduz a filmes de propriedades elétricas ruins.

Quanto à potència usada para excitar o plasma, nós usamos um truque baseado na Lei de Paschen. Conforme descrito na Seção 3.2., esta lei relaciona a tensão de sustentação do plasma com o produto da pressão pela separação entre os eletrodos. Nós não construímos o gráfico correspondente à Lei de Paschen; porém, nós usamos 
uma tensão aplicada aos eletrodos levemente superior àquela necessária para sustentar o plasma, de acordo com a pressão dos gases na câmara. Valores típicos da tensão nos eletrodos foram de $450 \mathrm{~V}$, e a corrente medida através do plasma foi de cerca de $4 \mathrm{~mA}$, o que leva a uma potência do plasma de cerca de $1,8 \mathrm{~W}$, correspondendo a uma densidade de potência de aproximadamente $0,01 \mathrm{~W} / \mathrm{cm}^{2}$.

Em relação ao fluxo de gases, o reator foi caracterizado na deposição de filmes usando dois tipos de fluxo:

i) um, chamado de fluxo baixo, correspondendo a cerca de $10 \mathrm{~cm} 3 / \mathrm{min}$;

ii) e o segundo, chamado de fluxo alto, correspondendo a cerca de 100 $\mathrm{cm}^{3} / \mathrm{min}$.

Assim, desconsiderando o fluxo de gases e a potência do plasma, esta última mantida fixa ao longo da deposição, e escolhendo apenas duas posições para o fluxo, os parâmetros que realmente variamos para caracterizar o reator foram a pressão de deposição e a temperatura do substrato. 


\section{SEÇÃO 4}

\section{CARACTERIZAÇÃO DOS FILMES}

\subsection{Introdução}

Nesta Seção faremos uma descrição das técnicas por nós utilizadas para caracterizar as propriedades do silício amorfo hidrogenado ( $a$-Si:H) obtido por descarga luminescente a baixa frequência, no sistema de deposição descrito na Seção 3 deste trabalho.

$\mathrm{Na}$ etapa de desenvolvimento do projeto de obtenção dos filmes de $a$-Si:H por descarga luminescente (glow discharge) a $60 \mathrm{~Hz}$, a caracterização dos filmes teve como objetivos principais, primeiro obter os parâmetros nos quais o reator produz filmes de qualidade eletrônica, e posteriormente levantar dados de algumas propriedades estruturais e de transporte deste material.

Para a primeira parte da caracterização, que podemos chamar mais propriamente de caracterização do reator, nós elegemos como propriedades fundamentais a condutividade no escuro $\sigma_{d}$ e a foto-sensibilidade $F S$ (a razão entre a fotocondutividade $\sigma_{p h}$ e $\sigma_{d}$ ) do material. Na medida de $\sigma_{d}$, aproveitamos o sistema experimental para medir também a energia de ativação $E_{a}$ do processo de condução; este resultado, mais a medida do gap óptico fornece uma boa indicação do valor do Nível de Fermi do material, como veremos a seguir. Na caracterização do reator nós também investigamos propriedades estruturais dos filmes, mais especificamente o número de ligações $\mathrm{SiH}$ e $\mathrm{SiH}_{2}$, através de medidas de transmitância no infra-vermelho distante.

Conforme foi discutido na Seção 3.11. deste trabalho, os parâmetros variados na caracterização do reator foram a pressão de deposição e a temperatura do substrato. A pressão de deposição foi variada desde 0,1 torr até 2,0 torr, enquanto que a temperatura foi variada na faixa de 50 a $250^{\circ} \mathrm{C}$. Para os resultados mostrados ainda nesta Seção, quando a pressão de deposição é variada a temperatura do substrato é 
mantida em $170{ }^{\circ} \mathrm{C}$, ao passo que quando variamos a temperatura do substrato a pressão de deposição é mantida a 0,5 torr. As razões para estas escolhas ficarão claras no relato a seguir.

Para os filmes de qualidade eletrônica (segundo indicação de $F S$ e de $\sigma_{d}$ ) realizamos medidas complementares para aferir propriedades estruturais e de transporte. No caso da estrutura, nós medimos a Energia de Urbach $E_{0}$ do material, uma indicação da desordem estrutural presente nos filmes ${ }^{66}$; a técnica por nós usada para medir o Urbach edge é conhecida por Constant Photocurrent Method (CPM). No caso do transporte de portadores, nós medimos o comprimento de difusão ambipolar $L_{d}$, através da técnica conhecida como Steady State Photocarrier (Irating (SSPG). Para efeito de comparação, estas propriedades foram medidas em dois tipos de filmes:

i) um primeiro tipo, depositado em condições ótimas, quais sejam pressão de deposição de 0,5 torr, temperatura de substrato de $170^{\circ} \mathrm{C}$, e fluxo alto;

ii) um segundo tipo, depositado ainda em condições ótimas, porém agora com o fluxo baixo.

As propriedades destes dois tipos de filmes foram também comparadas com as de um depositado segundo procedimento padrão, qual seja descarga luminescente a RF.

Em relação às propriedades, podemos classificar a caracterização por nós realizada em três tipos básicas:

i) caracterização elétrica e elétro-óptica,

ii) caracterização óptica,

iii) e caracterização estrutural.

Passamos agora a descrever cada uma das técnicas usadas na caracterização dos filmes de $a$-Si:H, segundo a divisão apontada acima. No final da descrição das técnicas, nós mostramos os resultados obtidos para os filmes obtidos no reator a $60 \mathrm{~Hz}$. 


\subsection{Caracterização Elétrica e Eletro-Óptica}

Neste item descreveremos as técnicas elétricas e eletro-ópticas usadas para caracterizar os filmes de $a$-Si:H. Aqui, damos ênfase nas medidas relacionadas com a fotocondutividade (a própria $\sigma_{p h}$, a medida do parâmetro $\gamma$, e a medida do comprimento de difusão ambipolar $L_{d}$ ), mais a medida da condutividade no escuro $\sigma_{d}$. No que diz respeito à medida de $\sigma_{p h}$ e a de $\gamma$ seremos bastante genéricos, já que tratam-se de técnicas bastante conhecidas; por outro lado, na medida de $L_{d}$ seremos detalhistas, já que trata-se de uma técnica recente, elegante, prática, e segundo nosso conhecimento até agora inédita no Brasil.

\subsubsection{Fotocondutividade}

Os filmes finos de $a$-Si:H caracterizam-se pelo elevado valor da sua fotosensibilidade; os melhores resultados indicam valores da ordem de $10^{5}$ para esta propriedade. Isto significa que amostras de qualidade eletrônica de $a$-Si:H devem apresentar, simultaneamente, alta fotocondutividade e baixa condutividade no escuro. Daí, tornarem-se imperiosas as medidas destas propriedades.

A fotocondutividade é um incremento na condutividade elétrica a partir da geração de pares elétrons-buracos no interior do semicondutor pela absorção de fótons incidentes originários de uma fonte de radiação eletromagnética. O $a$-Si:H tem como característica principal o fato desta absorção de fótons ocorrer primordialmente na região de emissão do espectro solar. Isto faz com que este material tenha aplicações óbvias em dispositivos que utilizem a conversão fotovoltaica.

A absorção fundamental ocorre quando um elétron é excitado a partir da banda de valência para a banda de condução através da absorção de um fóton. Apesar da descrição em termos de bandas de energia ser típica de materiais cristalinos, é possivel a utilização destes termos para o $a$-Si:H; neste caso, as bandas de energia são originárias das configurações ligante e anti-ligante das ligações químicas Si-Si presentes no sólido; nesta descrição, o elevado número de estados presentes no gap é explicado pelas ligações químicas $\mathrm{Si}-\mathrm{H}$, cuja energia se localiza exatamente entre as energias dos estados ligante e anti-ligante ${ }^{67}$. 
O fenômeno da condução é de especial interesse no estudo da física dos semicondutores. A condução consiste no movimento dos elétrons e buracos, e só é possivel quando uma certa quantidade de energia cinética pode ser transferida aos portadores. Isto ocorre quando a energia dos fótons que incidem sobre o semicondutor é suficiente para vencer o seu gap de energia.

Em geral, a fotocondutividade é medida com uma luz branca, cuja potência é controlada por uma fonte estabilizada e medida por um dispositivo fotovoltaico calibrado. Por motivos de facilidade, nós optamos por usar como fonte de excitação luminosa um laser de He-Ne $(\lambda=0,6328 \mu \mathrm{m})$ cuja potência é de $5 \mathrm{~mW}$; este comprimento de onda é suficiente para excitar portadores acima da banda de condução, já que o gap de energia deste material não excede a $1,8 \mathrm{eV}$, o que corresponde a $\lambda=0,6875 \mu \mathrm{m}$.

$\mathrm{O}$ dispositivo experimental usado para medir a fotocondutividade é bastante simples, consistindo apenas de um laser He-Ne Modelo HN-40-P da Carl Zeiss, e de um espelho convexo, cuja função é abrir o feixe laser de forma que o seu spot cubra toda a região entre os contatos elétricos. Estes contatos consistem de duas faixas coplanares (largura de $1 \mathrm{~mm}$ e espaçamento de $0,5 \mathrm{~mm}$ ) de tinta prata ou alumínio. A fonte de tensão e o eletrômetro estão agrupados no mesmo equipamento, um eletrômetro Keithley Modelo 617; para as medidas de corrente usamos uma tensão de $40 \mathrm{~V}$. Um esquema experimental deste dispositivo pode ser visto na Figura 4.1.. Com este arranjo, o valor da fotocondutividade é dado por:

$$
\sigma_{p h}=\frac{l}{e d V} I_{p h}
$$

onde $l$ é o comprimento dos contatos, $d$ o espaçamento entre eles, $e$ a espessura da amostra, $V$ a tensão aplicada entre os contatos, e $I_{p h}$ a fotocorrente medida no eletrômetro. 


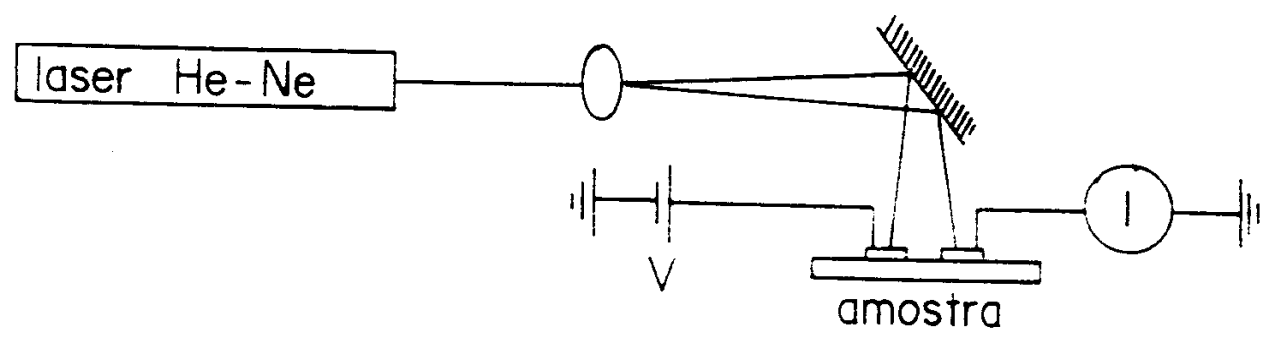

Figura 4.1. Esquema Experimental usado para medir a Fotocondutividade.

\subsubsection{Condutividade no Escuro}

Embora o a-Si:H seja fortemente fotocondutor, o conhecimento do valor da sua condutividade no escuro é muito importante na caracterização deste material. A razão para este fato reside em que a qualidade do filme depositado pode ser averiguada quando a condutividade é medida em função da temperatura.

Se o filme de $a$-Si:H apresentar boa qualidade, devemos esperar um comportamento do tipo Arrhenius para a condutividade ${ }^{68}$, isto é:

$$
\sigma_{d}=\sigma_{0} \exp \left(-\frac{E_{a}}{k_{B} T}\right)
$$

que é caracterísitica de sistemas termicamente ativados; na Equação (4-2), $E_{a}$ é a energia de ativação do processo de condução, $k_{B}$ é a constante de Boltzmann e $T$ a temperatura da amostra.

Caso a qualidade do filme depositado não seja boa, devemos esperar um comportamento diferente para a condutividade. Como é conhecido, uma das principais caracterísiticas do $a$-Si:H é apresentar uma elevada densidade de estados no gap; quando isto acontece, uma outra possibilidade para o processo de condução é o salto (hopping) dos portadores de estado para estado dentro do gap, até que estes alcancem a banda de condução. Este processo é bastante ineficiente, uma vez que os portadores tem que passar por inúmeros estados intermediários até chegarem à banda de condução. $\mathrm{O}$ processo de condução por saltos em materiais não-cristalinos foi 
extensivamente estudado por Mott ${ }^{69}$, e sua teoria para este tipo de condução apresenta o seguinte resultado para o comportamento da condutividade em função da temperatura:

$$
\sigma=\sigma_{00} \exp \left(-\frac{B}{T^{l+4}}\right)
$$

onde $\sigma_{00}$ e $B$ são constantes que dependem da estrutura eletrônica dos estados do gap. Como pode ser visto pela Equação (4-3), o comportamento da condutividade com a temperatura considerando apenas a condução por saltos é completamente diferente daquele levando em conta um processo do tipo Arrhenius.

Esta diferença permite usar a medida da condutividade elétrica em função da temperatura para ter uma indicação sobre a qualidade do filme: filmes de boa qualidade devem obedecer a Equação (4-2), enquanto que filmes de pior qualidade obedecem a Equação (4-3), já que neste caso o material possui um número muito grande de estados no gap.

Por fim, caso o filme de $a$-Si:H seja de boa qualidade, esta medida da condutividade no escuro em função da temperatura pode ainda fornecer informações sobre o Nível de Fermi do material. A partir da Equação (4-2), fazendo um gráfico de $\log (\sigma) \times(1 T)$, obtemos diretamente o valor da energia de ativação $E_{a}$. É possível, a partir de primeiros princípios, obter uma expressão para $E_{a}$ em função de grandezas mais fundamentais. Seguindo o cálculo sugerido por Mott e Davies ${ }^{70}$, obtemos o seguinte resultado para a energia de ativação:

$$
E_{a}=E_{g}-E_{F},
$$

onde $E_{g}$ é o valor do gap de energia do material, e $E_{F}$ o seu Nível de Fermi.

A medida da condutividade no escuro, e indiretamente da energia de ativação do processo de condução, envolve a elevação da temperatura da amostra a um valor 
menor do que a temperatura de deposição, pois caso contrário mudanças estruturais podem ocorrer no material. Em termos práticos, neste experimento a temperatura deve ser elevada até cerca de $180^{\circ} \mathrm{C}$; esta é uma temperatura suficientemente elevada para que, caso ele seja conduzido em atmosfera ambiente, a amostra seja contaminada por gases aí presentes, principalmente oxigênio e carbono.

Para superar esta dificuldade, projetamos uma câmara metálica que pudesse ser evacuada, na qual o experimento foi conduzido. Trata-se de uma câmara simples, toda ela de aço inoxidável, com seis entradas laterais, sendo uma delas destinada para as bombas de vácuo; as demais são alimentadores (feed-throughs) destinados para 0 medidor de vácuo, contatos elétricos entre a fonte de tensão/eletrômetro e a amostra, resistência para o aquecimento da amostra, fio para o termopar, e uma conexão para o fluxo de $\mathrm{N}_{2}$ seco. $\mathrm{O}$ aquecimento da amostra é garantido pela existência de uma base de latão na qual estão inseridas duas resistências elétricas do tipo cartucho de $750 \mathrm{~W}$ cada uma. Um esquema desta câmara está mostrada na Figura 4.2.

Um dispositivo do tipo pinça com pressão foi projetado para servir de contato elétrico entre os contatos metálicos sobre a amostra e os fios que saem da fonte de tensão/eletrômetro. $O$ termopar também é pressionado sobre a amostra com uma pinça deste tipo, só que esta última possui na extremidade um pedaço de teflon para fazer o isolamento elétrico. O termopar está ligado a um eletrômetro analógico Keithley Modelo 610-C. Tanto o sinal que vem do eletrômetro digital (que mede a corrente elétrica) quanto o que vem do eletrômetro analógico (que mede uma diferença de potencial associada à temperatura) estão ligados a um microcomputador XT, responsável pela aquisição dos dados desta experiência. Um programa de computador especialmente projetado para este fim converte a medida de corrente em condutividade, e a medida da ddp no termopar em temperatura absoluta. Por fim, com o resultado convertido em uma tabela, é possível construir um gráfico $\ln (\sigma) \times(1 / T)$, e, caso ele se mostre uma linha reta, extrair dele o valor da energia de ativação. 


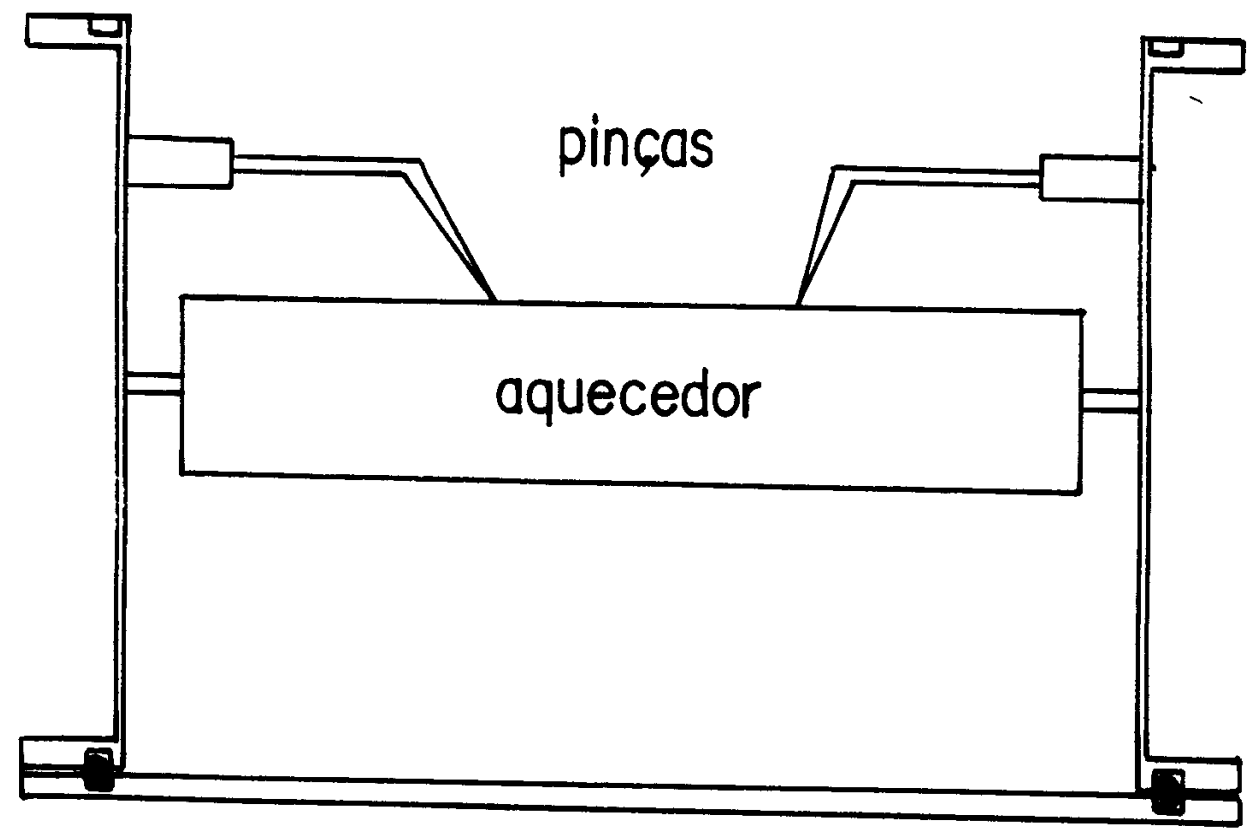

Figura 4.2. Câmara projetada para medir a Condutividade no Escuro.

A medida pura e simples da condutividade no escuro é feita neste mesmo sistema, agora mantido a temperatura ambiente, com a câmara coberta com a mesma tampa usada para fazer o vácuo. Neste caso, bem como na situação em que a temperatura varia, a condutividade no escuro é dada por:

$$
\sigma_{d}=\frac{l}{e d V} I_{d}
$$

onde $l$ e $d$ são grandezas geométricas associadas aos contatos, $e$ a espessura, $V$ a tensão aplicada nos contatos, e $I_{d}$ a corrente de escuro medida no eletrômetro.

\subsubsection{Foto-Sensibilidade}

A foto-sensibilidade $F S$ é simplesmente definida como sendo a razão entre a fotocondutividade $\sigma_{p h}$ e a condutividade no escuro $\sigma_{d}$. Assim sendo, temos que:

$$
F S=\frac{\sigma_{p h}}{\sigma_{d}}
$$

Na realidade, a foto-sensibililidade é uma medida de quão grande é a influência da luz nas propriedades de transporte do semicondutor. No caso do $a$-Si:H, é desejável 
que os filmes tenham a maior $F S$ possível, devido à sua aplicabilidade em dispositivos fotovoltaicos.

A obtenção de FS é imediata, a partir das medidas feitas como descritas nos ítens anteriores. Assim, admitindo que os contatos sejam os mesmos nos dois casos, e que a tensão aplicada também seja a mesma, usando a Equação (4-1) e a Equação (45), temos que:

$$
F S=\frac{I_{p h}}{I_{d}}
$$

\subsubsection{Medida do Fator $\gamma$}

Como comentado acima, a fotocondutividade é uma alteração na condutividade elétrica quando um material é exposto à radiação eletromagnética. Um excesso na condutividade $\sigma_{p h}$ aparece, se sob a ação da luz absorvida, as densidades de portadores $n$ (elétrons) e $p$ (buracos) aumentam quando comparados com seus valores no equilíbrio térmico. Assim, a fotocondutividade é escrita como sendo:

$$
\sigma_{p h}=e\left(\Delta n \mu_{n}+\Delta p \mu_{p}\right)
$$

onde $e$ é a carga elétrica elementar, $\Delta n$ e $\Delta p$ os excessos nas densidades de portadores devido à luz absorvida, e $\mu_{n, p}$ as mobilidades destes portadores. Em estado estacionário, os excessos nas densidades são iguais ao produto da taxa de geração de portadores $G$ (isto é, o número de portadores gerados por unidade de tempo, por unidade de volume) pelo seu respectivo tempo de vida $\tau_{n, p}$; assim:

$$
\begin{aligned}
& \Delta n=G \tau_{n} \\
& \Delta p=G \tau_{p} .
\end{aligned}
$$


$O$ número de portadores em não-equilíbrio existe até que eles desapareçam por recombinação, o que pode ocorrer, em geral através de três processos:

i) recombinação direta de um elétron livre com um buraco livre,

ii) captura de um elétron por um centro no qual um buraco está localizado,

iii) captura de um buraco por um centro no qual existe um elétron ligado.

Se apenas um tipo de centro de recombinação está presente, o tempo de recombinação de não-equilíbrio é governado pelo processo de captura do elétron $\mathrm{e}$ subsequente captura do buraco pelos níveis locais do centro dominante. Contudo, quando diferentes centros de defeitos atuam como níveis de armadilhas e/ou recombinação, a análise torna-se muito mais complicada uma vez que é preciso considerar uma série de possíveis transições para elétrons e buracos, e então escrever equações correspondentes que descrevam a taxa de alteração na ocupação destes níveis. Este é o caso dos semicondutores amorfos, em particular do $a-\mathrm{Si}: \mathrm{H}$.

A taxa de variação de portadores, quer sejam eles elétrons ou buracos é igual à taxa de geração $G$ menos a taxa de recombinação R. Para elétrons, temos por exemplo que:

$$
\frac{\partial \Delta n}{\partial}=G-R
$$

No entanto, para uma melhor compreensão dos resultados experimentais da fotocondutividade, vamos considerar um modelo simples de semicondutor com apenas um tipo de centro de recombinação ${ }^{71}$. Admitindo que um excesso na densidade de elétrons $\Delta n$ é estabelecida por uma excitação luminosa, que o material seja intrínseco (isto é, $n_{0}=p_{0}$ ), e que a neutralidade de carga espacial seja mantida (isto é, $\Delta n=\Delta p$ ), temos então que a taxa de variação do excesso de portadores é escrita na forma:

$$
\frac{\partial \Delta n}{\partial t}=G-\left[C_{n} N_{r}\left(n_{0}+\Delta n\right)-C_{n} n_{0}^{2}\right]
$$


onde $n_{0}$ é a densidade dos portadores disponiveis para recombinarem-se com o excesso de portadores, $C_{n}$ é o coeficiente de captura (isto é, o produto da seção de choque para a captura de elétrons livres na recombinação pela velocidade térmica média dos portadores), e $N_{r}$ é a concentração dos centros de recombinação. No estado estacionário vale que:

$$
\frac{\partial \Delta n}{\partial}=0
$$

e sob as condições mencionadas acima vale também que:

$$
N_{r}=n_{0}+\Delta n
$$

Desta forma, obtemos a seguinte expressão para a taxa de geração de portadores:

$$
G=C_{n}\left(\Delta n^{2}+2 n_{0} \Delta n\right)
$$

Esta relação fornece uma visão direta da dependência de $\Delta n$ com a taxa de geração de portadores. Mas $G$ está relacionada com a intensidade da luz $I$ através da relação:

$$
G=\frac{\eta \alpha}{\hbar \omega} I
$$

onde $\alpha$ é o coeficiente de absorção do material para uma frequência da luz $\omega$.

A Equação (4-14) mostra dois comportamentos para $\Delta n$ em relação à intensidade $I$ :

i) no regime em que $n_{0} \gg \Delta n$, isto é, o excesso de portadores induzidos por luz é muito menor do que aqueles existentes em equilíbrio térmico, temos então: 


$$
\Delta n=\frac{\eta \alpha}{2 \hbar \omega C_{n} n 0} I .
$$

ii) por outro lado, quando $n_{0} \ll \Delta n$, temos então que:

$$
\Delta n=\left(\frac{\eta \alpha}{\hbar \omega C_{n}}\right)^{1 / 2} I^{1 / 2}
$$

Por outro lado, a partir da Equação (4-8), e levando em conta a neutralidade de carga, a fotocondutividade é proporcional a $\Delta n$, isto é:

$$
\sigma_{p h}=e\left(\mu_{n}+\mu_{p}\right) \Delta n
$$

Isto significa que na situação i) a fotocondutividade é proporcional à intensidade da luz, ao passo que na situação ii) ela é proporcional à raiz quadrada de $I$.

A descrição acima é bastante simplificada, e a princípio serve para qualquer tipo de semicondutor. Para o $a$-Si:H, no entanto, nem o coeficiente da intensidade é 1 , nem 1/2. Segundo Rose ${ }^{72}$, o comportamento de $\sigma_{p h}$ em relação à intensidade para materiais desordenados é da forma:

$$
\sigma_{p h} \propto I^{\gamma}
$$

onde o $\gamma$ é um fator entre $1 / 2$ e 1 . Em $\gamma$ está inserida a dependência da taxa de recombinação com a concentração de portadores, além da complexidade dos processos recombinantes.

A análise feita acima mostra a importância da medida de $\gamma$. Para o a-Si:H, onde é desejável que tenhamos um grande excesso de portadores devido à luz, o comportamento esperado para a fotocondutividade é aquele mostrado pela Equação (417), isto é que o fator $\gamma$ seja próximo de $1 / 2$. Desta forma, valores de $\gamma$ próximos de 1 
indicariam que o nímero de portadores gerados pela luz não é significante, e então 0 material não seria de boa qualidade.

O processo de medida deste fator é bastante simples. Com o mesmo sistema experimental usado para medir a fotocondutividade, e com o auxílio de filtros neutros para $\lambda=0,6328 \mu \mathrm{m}$, montamos 0 sistema mostrado na Figura 4.3.. Usando um conjunto de filtros neutros na faixa de $60 \%$ a $3 \%$ de redução da intensidade de luz, é possível varrer uma escala de 3 ou mais ordens de grandeza na intensidade da luz; para cada arranjo de filtros medimos a fotocorrente, e a partir da Equação (4-1) obtemos 0 valor de $\sigma_{p h}$. A partir daí, levantando um gráfico de $\log \left(\sigma_{p h}\right) \times \log (l)$, determinamos 0 valor de $\gamma$ como sendo a tangente da reta em questão.

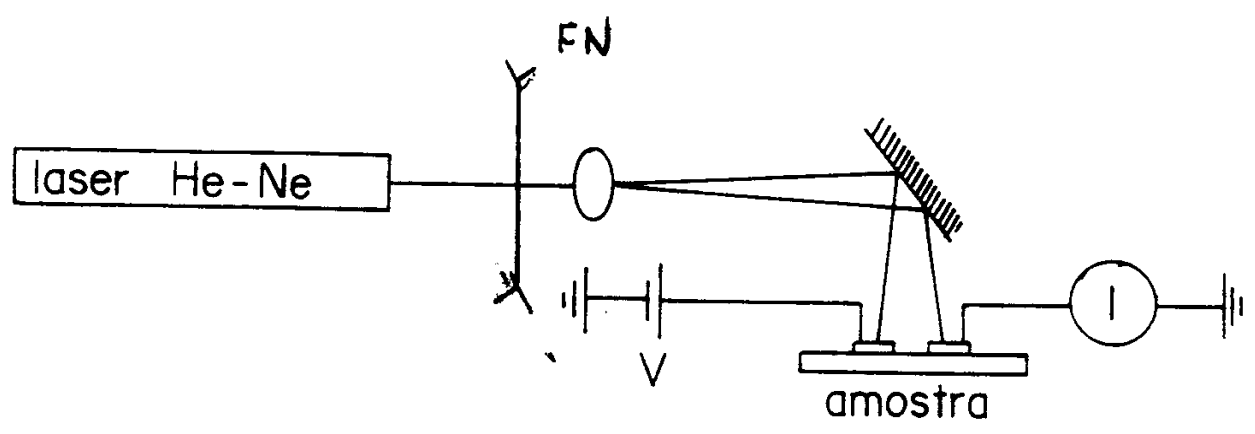

Figura 4.3. Esquema Experimental usado para medir o fator $\gamma$.

\subsubsection{A Medida do Comprimento de Difusão Ambipolar}

É bem conhecido que os parâmetros vitais que determinam a operação de dispositivos fotovoltaicos são determinados pelo comprimento de difusão de portadores minoritários. $O$ conhecimento de valores precisos deste parâmetro é ainda mais importante quando os dispositivos são construídos a partir de semicondutores amorfos $^{73}$, já que neste caso as propriedades eletrônicas são extremamente dependentes da absorção da luz pelo material. Uma técnica bastante usada na determinação do comprimento de difusão, principalmente em semicondutores cristalinos, é a medida de fotovoltagem superficial (SPV, Surface Photovoltage $\underline{\text { Method) }}{ }^{74,75}$; esta técnica apresenta como dificuldade principal, a necessidade do uso 
de sondas especiais que detectem a fotovoltagem superficial, o que torna o sistema experimental bastante complexo. Além disso, esta técnica mostrou-se inapropriada para o silício amorfo hidrogenado $(a-\mathrm{Si}: \mathrm{H})$.

Duas técnicas mais recentes utilizam a indução de uma grade de fotoportadores através da interferência de luz coerente para o estudo da difusão dos portadores em semicondutores, particularmente em $a-\mathrm{Si}: \mathrm{H}$. Uma delas é conhecida como técnica de

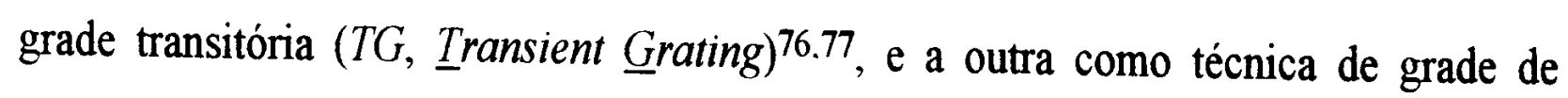
fotoportadores em estado estacionário (SSPG, Steady State Photocarrier Grating) ${ }^{78.79}$. Como o próprio nome já diz, a técnica $T G$ é feito em regime transitório e a técnica de SSPG em regime estacionário.

Na técnica $T G$, o padrão de interferência produz uma variação senoidal na concentração dos fotoportadores, o que induz uma mudança periódica no índice de refração e no coeficiente de absorção do material. O movimento dos fotoportadores devido a difusão é então monitorado pela evolução temporal da luz difratada por esta grade.

Na técnica de $S S P G$, sugerido por Ritter et al78, determinamos o comprimento de difusão ambipolar, o qual esta relacionado com o comprimento de difusão dos portadores minoritários. Este método é baseado no estabelecimento de uma grade de fotoportadores na amostra, seguida da medida das fotocondutividades na presença e na ausência desta grade. A existência de difusão dos fotoportadores faz com que esta grade seja diferente daquela induzida pelo laser, já que a difusão "borra" este perfil; assim, a difusão produz uma mudança na fotocondutividade, que depende da relação entre o período da grade e o comprimento de difusão. Esta nova técnica é de fácil medida e é atualmente amplamente empregada na determinação do comprimento de difusão ambipolar de fotoportadores em amostras de $a$-Si:H obtido por descarga luminescente $(G D)$.

A grande limitação desta técnica é o uso da hipótese da neutralidade da carga espacial, a qual é assumida formalmente na obtenção das equações que regem o transporte ambipolar, mas que nem sempre é verdadeiro na prática. Trata-se de um 
assunto muito estudado atualmente 79,80 , e muito complexo, merecendo ainda estudos para ser possível chegar a conclusões definitivas. Aqui, os valores do comprimento de difusão ambipolar são obtidos considerando que o material não sofre efeito da carga espacial, e as condições experimentais de intensidade de luz e de campo aplicado estão no regime de difusão ambipolar. No entanto, faremos uma breve discussão sobre a influência da não-neutralidade da carga sobre os resultados obtidos pela técnica.

Aqui mostraremos os fundamentos teóricos e experimentais, envolvidos na técnica de $S S P G$, e a possível aplicação deste método como uma técnica suficientemente precisa, a ser usada para medida do comprimento de difusão dos fotoportadores minoritários em filmes finos de $a-\mathrm{Si}: \mathrm{H}^{80}$. Este mesmo sistema experimental tem ganho extrema importância para medidas do produto das variáveis mobilidade-tempo de vida $(\mu \tau)$ dos dois tipos de portadores de carga ${ }^{81,82}$; estes parâmetros contém informações a respeito do mecanismo de transporte $(\mu)$ e o mecanismo de cinética de recombinação $(\tau)$.

A interferência entre dois feixes de luz tem sido largamente utilizada na medida do comprimento de difusão do excesso de portadores em semicondutores. A técnica conhecida como SSPG envolve o uso de uma grade de fotoportadores produzida pela interferência de dois feixes de luz laser coerente. Devido à intensidade da luz usada ser suficientemente fraca, esta técnica tem o mérito de ser livre de qualquer efeito térmico que porventura possa contribuir para a formação da grade. Nesta técnica a grade de fotoportadores tem uma pequena modulação que pode ser tratada como uma perturbação da iluminação de fundo uniforme. Desta forma, um tratamento matemático linear se justifica ${ }^{83}$.

Para obter as equações que regem os fenômenos envolvidos na técnica SSPG é usado um formalismo para as equações de transporte de portadores baseado no conceito de mobilidade de arraste, ao invés do conceito de mobilidade de portadores livres. Esta aproximação é mais geral do que o modelo que assume apenas transporte por estados estendidos, uma vez que ela inclui o caso de condução por saltos. Uma vantagem adicional desta aproximação é que, quando ela trata do transporte ambipolar 
naturalmente surge a hipótese da neutralidade da carga, isto é, admite-se que o excesso de concentrações de elétrons e buracos sejam iguais. Esta hipótese é mais facilmente incorporada no formalismo que inclui o número total de portadores fotoexcitados, além dos portadores livres.

O ponto de partida para obter as equações de transporte que regem esta técnica é escrever a Equação da Continuidade para o transporte de elétrons e buracos no semicondutor quando este é iluminado. Ela é escrita levando em conta as contribuições do arraste e da difusão dos fotoportadores. A dependência temporal das concentrações de elétrons $(N)$ e de buracos $(P)$ surge devido à geração e recombinação destes portadores. Consideremos que ocorra uma pequena perturbação na outrora constante taxa de geração $G$, de forma que tenhamos, além da contribuição uniforme $G_{0}$, uma contribuição adicional $\Delta G$. O efeito desta perturbação sobre a Equação da Continuidade é torná-la agora:

$$
\begin{gathered}
\mu_{n} \Delta N \vec{\nabla} \cdot \vec{E}+\mu_{n}^{\prime} \vec{E} \cdot \vec{\nabla} \Delta N+D_{n} \nabla^{2} \Delta N+\Delta G-\Delta R=0, \\
-\mu_{p} \Delta P \vec{\nabla} \cdot \vec{E}-\mu_{p}^{\prime} \vec{E} \cdot \vec{\nabla} \Delta P+D_{p} \nabla^{2} \Delta P+\Delta G-\Delta R=0 .
\end{gathered}
$$

Na Equação (4-20) $\mu_{n}$ e $\mu_{p}$ são os valores médios das mobilidades de arraste para elétrons e buracos, respectivamente, em relação à concentração de portadores ${ }^{83}$, $D_{n}$ e $D_{p}$ são os coeficientes de difusão para elétrons e buracos, respectivamente, e $\Delta N$ e $\Delta P$ são os excessos de concentração de elétrons e buracos, respectivamente, devido à perturbação $\Delta G, \overrightarrow{\mathrm{E}}$ o campo elétrico e $\Delta R$ a taxa de recombinação devida ao excesso de concentração de portadores.

Para obtermos uma equação ambipolar (válida tanto para elétrons como para buracos) devemos acrescentar a Equação de Poisson, a qual acopla as expressões da Equação (4-20) ${ }^{84}$. No regime de tempo de vida, localmente observa-se que: 


$$
\Delta N=\Delta P
$$

Levando-se em conta a Equação (4-21) podemos combinar o conjunto de expressões da Equação (4-20) de maneira adequada em uma única equação de transporte ambipolar:

$$
\mu \vec{E} \cdot \vec{\nabla} \Delta N+D \nabla^{2} \Delta N+\Delta G-\Delta R=0
$$

onde:

$$
\mu=\frac{\mu_{n}^{\prime} \mu_{p}-\mu_{n} \mu_{p}^{\prime}}{\mu_{n}+\mu_{p}}
$$

e

$$
D=\frac{\mu_{p} D_{n}+\mu_{n} D_{p}}{\mu_{n}+\mu_{p}}
$$

são a mobilidade de arraste ambipolar e a constante de difusão ambipolar, respectivamente. Note que, pela Equação (4-23-a) a mobilidade ambipolar não é nula, como seria o caso para um semicondutor intrínseco. Isto torna necessário formular uma hipótese adicional: admite-se que as densidades de estados responsáveis pela mobilidade de elétrons e buracos tenham o mesmo comportamento exponencial ${ }^{83}$, o que implica que a mobilidade de arraste ambipolar seja nula. Admitindo este fato como verdadeiro, obtem-se a seguinte equação que rege a difusão do excesso de portadores:

$$
D \nabla^{2} \Delta N+\Delta G-\Delta R=0 .
$$


A taxa de recombinação $\Delta R$ é formulada de uma maneira fenomenológica para impedir a restrição a qualquer mecanismo de recombinação específico. Definindo $\tau$ como sendo o tempo de recombinação comum a elétrons e buracos no regime de tempo de vida, a taxa de recombinação $\Delta R$ é dada então por:

$$
\Delta R=\frac{\Delta N}{\tau}
$$

Chega-se então à seguinte expressão para o transporte ambipolar do excesso de portadores:

$$
L_{d}^{2} \nabla^{2} \Delta N-\Delta N+\tau \Delta G=0
$$

com:

$$
L_{d}=\sqrt{D \tau}
$$

sendo definido como o comprimento de difusão ambipolar do semicondutor.

Admitamos que a perturbação $\Delta G$ seja modulada apenas na direção perpendicular aos feixes de luz responsáveis pela interferência. Neste caso, a Equação (4-26) se reduz a uma equação diferencial de segunda ordem, a apenas uma variável, a qual chamaremos $x$. Assim, temos:

$$
L_{d}^{2} \frac{d^{2} \Delta N(x)}{d x^{2}}-\Delta N(x)+\tau \Delta G(x)=0
$$

A Equação (4-28) supõe que as amostras sejam suficientemente finas, de tal forma que seja possível admitir que a absorção de luz na direção perpendicular ao plano da amostra seja uniforme; desta forma, a difusão de portadores nesta direção 
pode ser desprezada. Além disso, desprezamos também a ocorrência de recombinação superficial, que resultaria numa inhomogeneidade adicional naquela direção.

Até agora pouco foi falado a respeito do comportamento de $\Delta G(x)$, apenas que devido à característica de interferência dos dois feixes de luz que incidem sobre o semicondutor, $\Delta G(x)$ modula uma grade de interferência sobre ele. Considerando dois feixes de luz coerentes, de intensidades $I_{l}$ e $I_{2}$, incidindo sobre a superficie do semicondutor, a intensidade de luz resultante sobre ela é dada por:

$$
I(x)=\left(I_{1}+I_{2}\right)\left[1+2 \gamma_{0} \frac{\sqrt{I_{1} I_{2}}}{\left(I_{1}+I_{2}\right)} \cos \left(\frac{2 \pi x}{\Lambda}\right)\right] \text {, }
$$

onde $\Lambda=\lambda 2 \operatorname{sen}(\delta / 2)$ é o período da grade de interferência formado sobre a superfície do semicondutor, $\lambda$ o comprimento de onda da luz incidente, e $\delta$ o ângulo formado pelos dois feixes. $O$ parâmetro $\gamma_{0}$ é um fator que varia entre 0 e 1 , associado à eficiência na formação do padrão de interferência.

A taxa de geração de portadores é diretamente proporcional à intensidade da luz que incide sobre o semicondutor, de forma que a taxa de geração total $G(x)$ é dada por:

$$
G(x)=G_{0}\left[1+2 \gamma_{0} \frac{\sqrt{I_{1} I_{2}}}{\left(I_{1}+I_{2}\right)} \cos \left(\frac{2 \pi x}{\Lambda}\right)\right]
$$

onde $G_{0}$ é a taxa de geração de fotoportadores devido à parte uniforme da intensidade da luz. A partir da Equação (4-30) é possivel dividir $G(x)$ em duas partes, uma composta da parte espacialmente uniforme $G_{0}$ e outra composta pela parte não uniforme $\Delta G(x)$ devido à interferência entre os dois feixes $I_{I}$ e $I_{2}$. Assim, temos que:

$$
\Delta G(x)=2 G_{0} \gamma_{0} \frac{\sqrt{I_{1} I_{2}}}{I_{1}+I_{2}} \cos \left(\frac{2 \pi x}{\Lambda}\right) .
$$

$$
\text { IFSC - SERVICOO DE BIBLIOTECA E }
$$


Substituindo a Equação (4-31) na Equação (4-28) obtemos a forma final da equação diferencial para a concentração do excesso de portadores, a qual é dada por:

$$
L_{d}^{2} \frac{d^{2} \Delta N(x)}{d x^{2}}-\Delta N(x)+2 \pi G_{0} \tau_{0} \frac{\sqrt{I_{1} I_{2}}}{\left(I_{1}+I_{2}\right)} \cos \left(\frac{2 \pi x}{\Lambda}\right)=0
$$

A solução para a Equação (4-32) é uma expressão da forma:

$$
\Delta N(x)=\frac{2 \pi G_{0} \gamma_{0}}{\left[1+\left(\frac{2 \pi L_{d}}{\Lambda}\right)^{2}\right]} \frac{\sqrt{I_{1} I_{2}}}{\left(I_{1}+I_{2}\right)} \cos \left(\frac{2 \pi x}{\Lambda}\right) .
$$

Como vemos, a concentração total de portadores é composta de uma parte uniforme $N_{0}$ (proveniente da taxa de geração $G_{0}$ ) e de uma componente não uniforme $\Delta N(x)$. Analogamente a este resultado, é possível escrever a fotocondutividade total do semicondutor $\sigma_{p h}(x)$ como sendo composta de uma componente uniforme $\sigma_{p h o}$ e de uma componente não uniforme $\Delta \sigma_{p h}(x)$. Levando em conta que a resposta da fotocondutividade à intensidade I é proporcional a I ${ }^{\gamma}$, como mostra a Equação (4-19), a expressão final para a fotocondutividade é:

$$
\sigma_{p h}(x)=\sigma_{p h 0}\left[1+A \cos \left(\frac{2 \pi x}{\Lambda}\right)\right]
$$

com: 


$$
A=\frac{2 \gamma_{0}}{\left[1+\left(\frac{2 \pi L_{d}}{\Lambda}\right)^{2}\right]} \frac{\sqrt{I_{1} I_{2}}}{\left(I_{1}+I_{2}\right)},
$$

onde A é chamado de amplitude da grade de fotoportadores.

A presença da interferência na direção $x$ faz com que a fotocondutividade medida nesta direção seja na verdade um valor médio. A expressão para o cálculo deste valor médio é:

$$
\sigma_{p h g}=\frac{\Lambda}{\int \frac{d x}{\sigma_{p h}(x)}},
$$

de onde, usando a Equação (4-34) chegamos a:

$$
\sigma_{p h g}=\sigma_{p h o} \sqrt{1-A^{2}}
$$

Tendo descrito o processo de formação da grade de fotoportadores, vamos descrever agora o procedimento empregado para medir o comprimento de difusão pela técnica $S S P G$. Como vimos, os dois feixes que iluminam a superfície do semicondutor interferem e formam uma grade. Se uma placa de retardação (por exemplo uma lâmina $\lambda / 2$ ) é colocada em frente ao feixe mais intenso $I_{l}$, a interferência irá ocorrer quando a lâmina $\lambda / 2$ estiver na posição neutra. Quando a lâmina é colocada na posição ativa, isto é, quando rodamos o plano de polarização de um dos feixes de $\pi / 2$, estes não mais interferem, e agora suas intensidades somam-se de maneira linear e uniforme.

Seja então $V_{\perp}$ a diferença de potencial lida no lock-in no caso em que não ocorra a interferência entre os dois feixes. Seja também $V / /$ a diferença de potencial lida no lock-in no caso em que ocorra esta interferência. Como apenas o feixe $I_{2}$ é 
"choppeado", o sinal $V_{\perp}$ será proprocional apenas à fotocondutividade gerada pelo feixe $I_{2}$, isto é:

$$
V_{\perp} \propto \sigma_{p h 0}-\sigma_{p h l}
$$

Por outro lado:

$$
V \quad \propto \sigma_{p h g}-\sigma_{p h l}
$$

Definindo o parâmetro $\beta$ como sendo:

$$
\beta=\frac{V_{1}}{V_{\perp}}
$$

obtemos:

$$
\beta=\frac{\sigma_{p h g}-\sigma_{p h l}}{\sigma_{p h 0}-\sigma_{p h l}}
$$

onde $\sigma_{p h g}$ é a fotocondutividade na presença da grade de portadores, ou seja, quando $I_{l}$ interfere com $I_{2}, \sigma_{p h 0}$ e $\sigma_{p h l}$ são respectivamente as fotocondutividades devido as contribuições uniformes de $I_{1}$ e $I_{2}$ (sem interferência) e a fotocondutividade devido apenas ao fexe $I_{l}$. É fácil ver daí que o lock-in lê a diferença da fotocondutividade de quando o feixe $I_{l}$ está incidindo, e de quando não está incidindo na amostra, tanto para o caso em que os dois feixes estão incoerentes ou estão coerentes.

Usando a lei de potência que relaciona a fotocondutividade com a intensidade chegamos a: 


$$
\beta=\frac{(1+\theta)^{\gamma} \sqrt{1-A^{2}}-1}{(1+\theta)^{\gamma}-1}
$$

onde:

$$
\theta=\frac{I_{2}}{I_{1}}
$$

Levando em conta que o feixe $I_{2}$ é bem menos intenso do que o feixe $I_{l}$, e manipulando a Equação (4-41) chegamos ao seguinte resultado:

$$
\frac{l}{\Lambda^{2}}=\frac{1}{\left(2 \pi L_{d}\right)^{2}} \sqrt{\gamma \gamma_{0}^{2}} \sqrt{\frac{2}{(1-\beta)(1+\gamma \theta)}}-\frac{1}{\left(2 \pi L_{d}\right)^{2}} .
$$

Variando a posição dos espelhos $\mathrm{M}_{1}$ e $\mathrm{M}_{2}$, e medindo $V_{\perp}$ e $V /$, podemos construir um gráfico de $A^{-2} \times[2(1-f)(1+\gamma \sigma)]^{1 / 2}$. Daí, determinamos o comprimento de difusão ambipolar $L_{d}$, extrapolando a reta deste gráfico, fazendo

$$
[2(1-\beta)(1+\gamma 6)]^{1 / 2} \rightarrow 0
$$

com o coeficiente angular desta mesma reta, com o valor de $L_{d}$ (determinado como exposto acima) e com o valor de $\gamma$ (determinado como indicado na Seção 4.2.4), determinamos o fator de qualidade da grade $\gamma_{0}$.

O sistema experimental está descrito esquematicamente na Figura 4.4..A fonte de luz coerente utilizada é um laser HeNe Modelo HN-40-P ( $\lambda=0,6328 \mathrm{~nm})$, polarizado, com $5 \mathrm{~mW}$ de potência. Como divisor de feixe (DF) usamos um filtro de interferência adequado para $\lambda=0,6328 \mathrm{~nm}$, posicionado a $45^{\circ}$ com relação ao feixe $I_{l}$. 


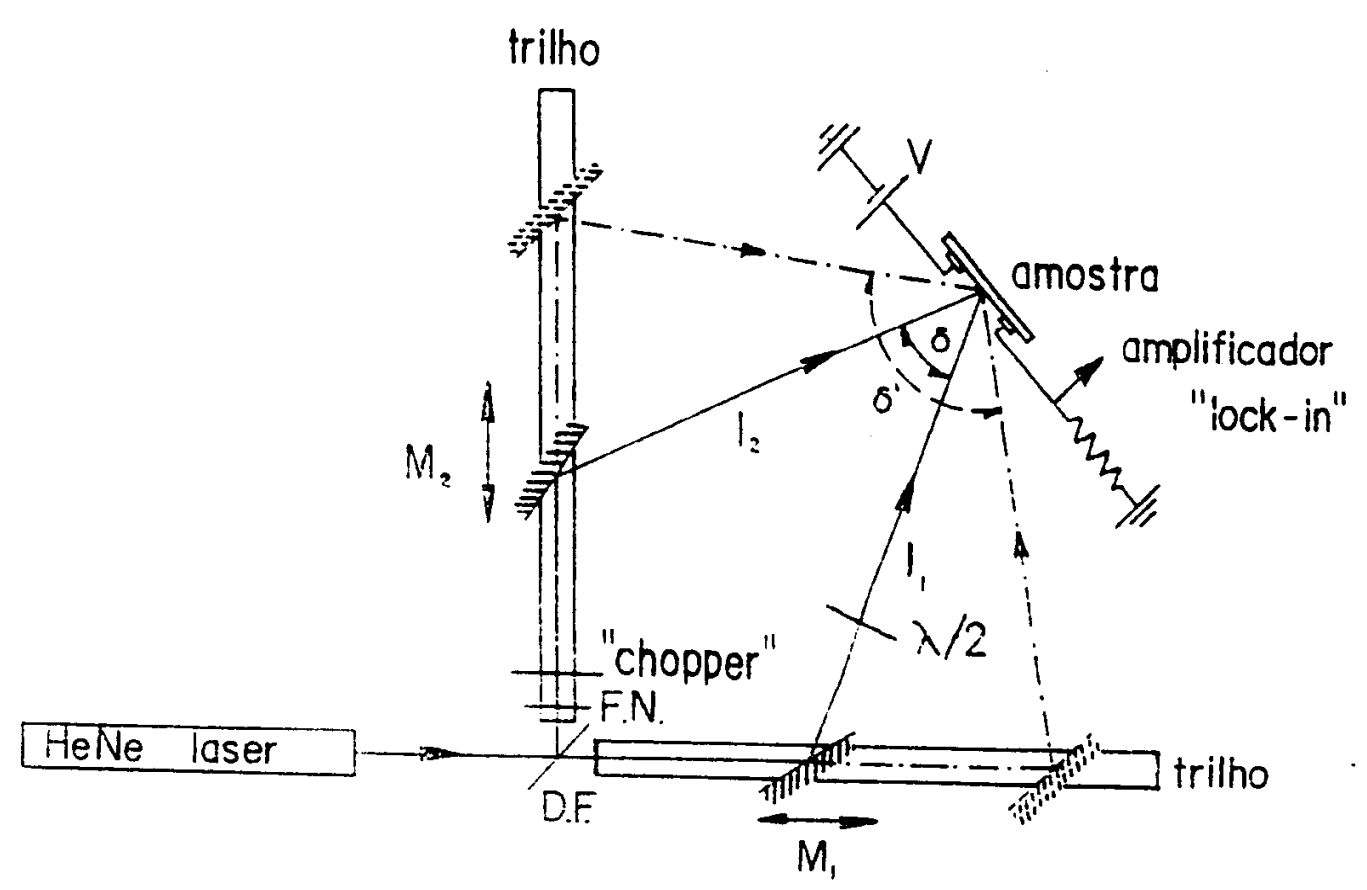

Figura 4.4. Esquema Experimental para medir o Comprimento de Difusão Ambipolar pela Técnica SSPG (Steady State Photocarrier Grating).

Os feixes percorrem duas trajetórias diferentes de mesmo percurso para depois incidirem sobre a amostra, sob um determinado ângulo $\delta$, e eventualmente interferirem produzindo um padrão de franjas perpendicular ao plano de incidência dos feixes, como mostra a Figura 4.4.. Na Figura 4.5. vemos também esquematicamente em detalhes os contatos de alumínio, o circuito elétrico e o ponto de incidência do laser.

$\mathrm{Na}$ trajetória do feixe $I_{2}$ usamos um filtro neutro (FN) adequadamente escolhido para fornecer a relação $20<I_{1} / I_{2}<50$; a seguir temos um chopper mecânico, do tipo pá rotativa, cuja frequência usada gira em torno de $100 \mathrm{~Hz}$; finalmente usamos um espelho de alumínio móvel $\mathrm{M}_{2}$ que direciona o feixe sobre a amostra de $a$-Si:H, exatamente entre os contatos metálicos onde é aplicado um pequeno campo elétrico. 


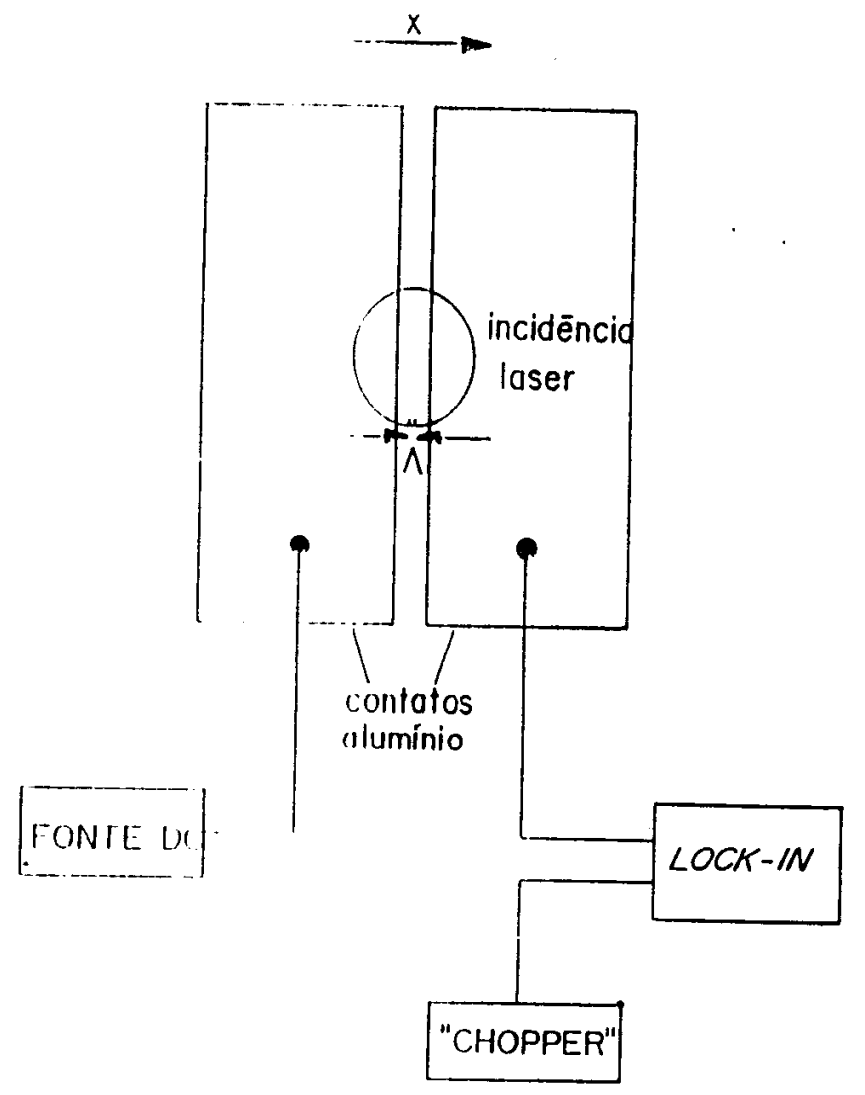

Figura 4.5. Vista Esquemática da Alimentação Elétrica (Fonte DC) e Leitura via Lock-in para a Medida do Comprimento de Difusão Ambipolar. No Desenho vemos com Ênfase o Ponto de Incidência dos dois feixes Laser, onde Eventualmente eles se interferem, criando uma Grade de Período $\Lambda$, Perpendicular à Direção $x$.

Já o feixe $I_{l}$, depois de passar pelo DF, incide diretamento sobre outro espelho móvel $\mathrm{M}_{1}$, que direciona o feixe sobre a amostra no mesmo ponto que o feixe $I_{2}$, para que possam eventualmente interferirem. $O$ feixe $I_{l}$ passa também por um conjunto de dois rombos de Fresnel, cuja função é rodar a polarização do feixe $I_{1}$ de $90^{\circ} \mathrm{em}$ relação ao feixe $I_{2}$. O rombo de Fresnel é usado na sua posição ativa quando deseja-se destruir a interferência entre os dois feixes.

Os dois espelhos de alumínio são montados num suporte rotativo móvel, e cada qual pode deslocar longitudinalmente num trilho rígido metálico de $60 \mathrm{~cm}$, dotado de graduação de $1 \mathrm{em} 1$ centímetro. Um trilho é posicionado $90^{\circ}$ com relação ao outro. $O$ deslocamento dos espelhos é simétrico com relação ao DF de tal forma a alterar o ângulo $\delta$ de incidência dos feixes de laser (ver Figura 4.4.); o ângulo $\delta$ pode ser assim 
facilmente calculado usando relações geométricas. Para cada ângulo $\delta$ temos um período $\Lambda$ correspondente à rede de fotoportadores.

Os ângulos $\delta$ típicos usados são da ordem de $6,5^{\circ}$ a $78,0^{\circ}$, produzindo períodos da rede $\Lambda$ de 5,5 a $0,5 \mu \mathrm{m}$. Esta faixa de ângulos permite determinar comprimentos de difusão na ordem de algumas centenas de angström até a ordem de alguns micrometros, adequadas portanto para amostras de $a-\mathrm{Si}: \mathrm{H}$ e suas ligas fotocondutivas.

No escuro, os semicondutores amorfos típicos, tais como o $a$-Si:H são claramente semicondutores ditos de relaxação, já que para estes materiais o tempo de relaxação dielétrico, definido como:

$$
\tau_{d}=\frac{K \varepsilon_{o}}{\sigma}
$$

é bastante longo por causa do baixo valor de sua condutividade. Quando o material é iluminado, contudo, a condutividade pode crescer de várias ordens de grandeza e este tempo $\tau_{d}$ irá então crescer. Assim, não é claro, a priori, se o regime de tempo de vida (onde a neutralidade de carga se mantém) ou o regime de tempo de relaxação aplica-se ao transporte ambipolar do excesso de portadores sob iluminação.

Para determinar qual regime de transporte aplica-se ao $a$-Si:H torna-se necessário resolver a Equação (4-20) sem levar em conta a neutralidade da carga, dada pela Equação (4-21). Resolvendo este problema para o caso unidimensional, considerando a taxa de geração de portadores como sendo dada pela Equação (4-30), a solução geral para $\Delta N(x)$ e $\Delta P(x)$ é apenas obtida numericamente em função da razão entre o tempo de recombinação e o tempo de relaxação dielétrica, $\tau \tau_{d}$. Este parâmetro mede a transição entre o regime de tempo de vida e o regime de relaxação. Simulações feitas considerando que o campo elétrico aplicado seja nulo, indicam que quando a relação $\tau / \tau_{d}$ é pequena, a neutralidade de carga local não é mais mantida e elétrons e buracos difundem; neste regime $\Delta N(x)$ diminui devido a rápida difusão dos elétrons, e a diminuição na taxa de recombinação conduz a um aumento de $\Delta P(x)$; por outro lado, 
quando $\tau / \tau_{d}$ admite valores da ordem de $10^{3}, \Delta N(x)$ e $\Delta P(x)$ tornam-se muito próximos, e nesta condição a neutralidade de carga é uma hipótese bastante aceitável.

As implicações práticas deste fato sobre as medidas obtidas pela técnica SSPG são imediatamente óbvias, dado que a Equação (4-34) não é mais válida. Assim, o resultado será claramente diferente quando se considera $\Delta N(x)=\Delta P(x)$ e o caso de comportamentos diferentes para as concentrações de elétrons e buracos. Resultados a partir de simulações mostram que o "verdadeiro" comprimento de difusão ambipolar iguala-se àquele medido pela técnica $S S P G$ quando as mobilidades de arraste para elétrons e buracos são as mesmas para qualquer valor de $\tau \tau_{d}$, dado que neste caso elétrons e buracos tem as mesmas constantes de difusão e a neutralidade de carga é sempre mantida: os resultados são também próximos quando $\tau / \tau_{d}$ é suficientemente grande para garantir a separação de cargas, mesmo quando $\mu_{n} \mathrm{e} \mu_{p}$ são diferentes.

\subsubsection{Resultados Experimentais}

As medidas da condutividade no escuro e da fotocondutividade em função da pressão de deposição estão mostradas na Figura 4.6. Para ambas as medidas estão mostradas a dependência com o fluxo.

A Figura 4.7, por outro lado, mostra a dependência da condutividade e da fotocondutividade com a temperatura do substrato, também para fluxo alto e baixo.

Na Figura 4.8. vemos o comportamento da energia de ativação da condutividade $E_{a}$ em função da pressão de deposição, e na Figura 4.9. esta mesma propriedade em função da temperatura do substrato. Em ambos os casos, está mostrada a dependência com o fluxo. O filme depositado pela técnica de descarga luminescente a RF mostrou uma energia de ativação de $0,71 \pm 0,05 \mathrm{eV}$, medida no mesmo sistema usado para caracterizar nossas amostras. 


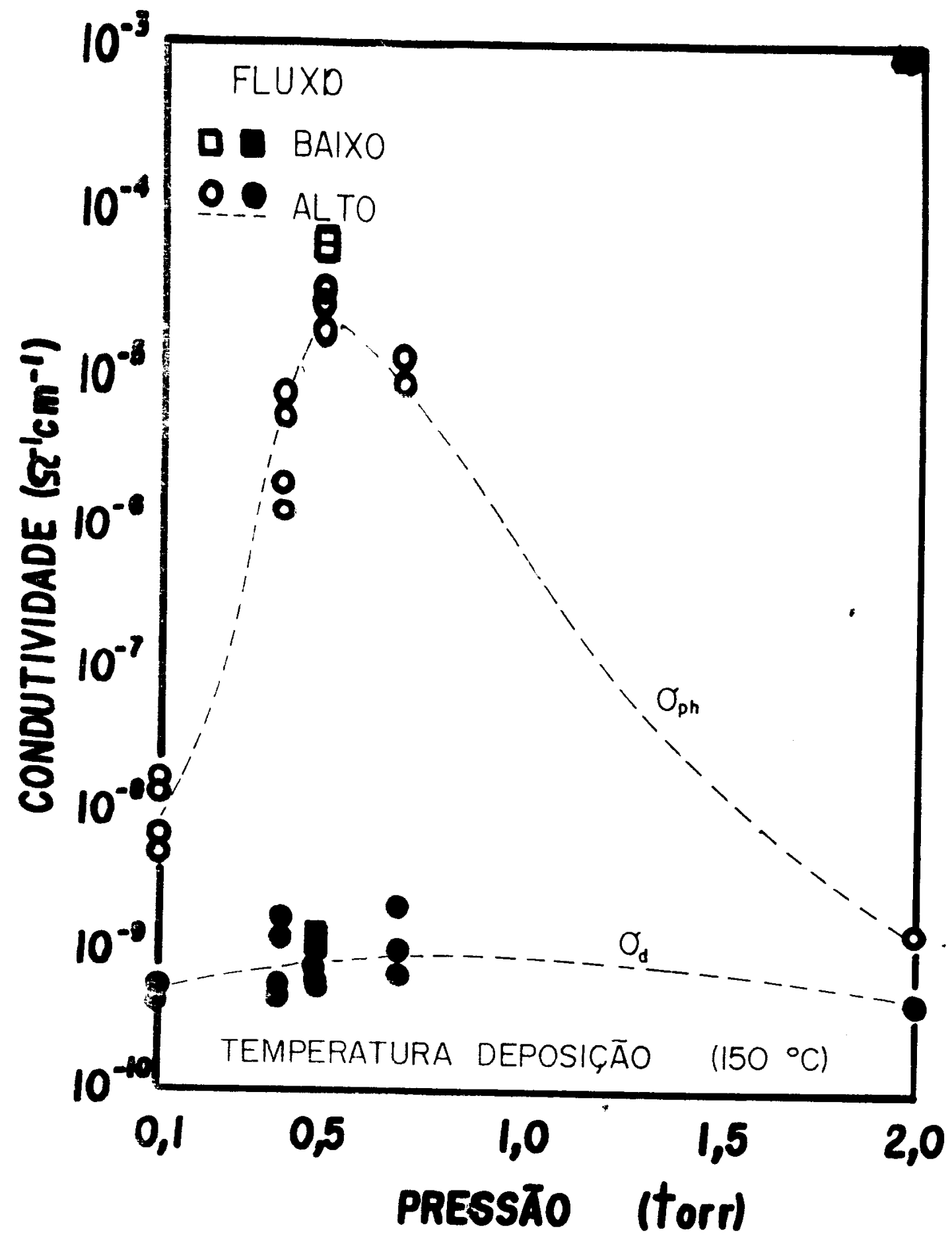

Figura 4.6. Medida da Condutividade no Escuro e da Fotocondutividade em Amostras depositadas a $60 \mathrm{~Hz}$ em Função da Pressão de Deposição: a) para Fluxo de $\mathrm{SiH}_{4}$ de $10 \mathrm{ml} / \mathrm{min}$ : b) para Fluxo de $\mathrm{SiH}_{4}$ de 100 $\mathrm{ml} / \mathrm{min}$. Em ambos os casos a densidade de potência usada foi de $0.01 \mathrm{~W} / \mathrm{cm}^{2}$. e a temperatura do substrato usada foi de $150^{\circ} \mathrm{C}$.

IFSC - S 


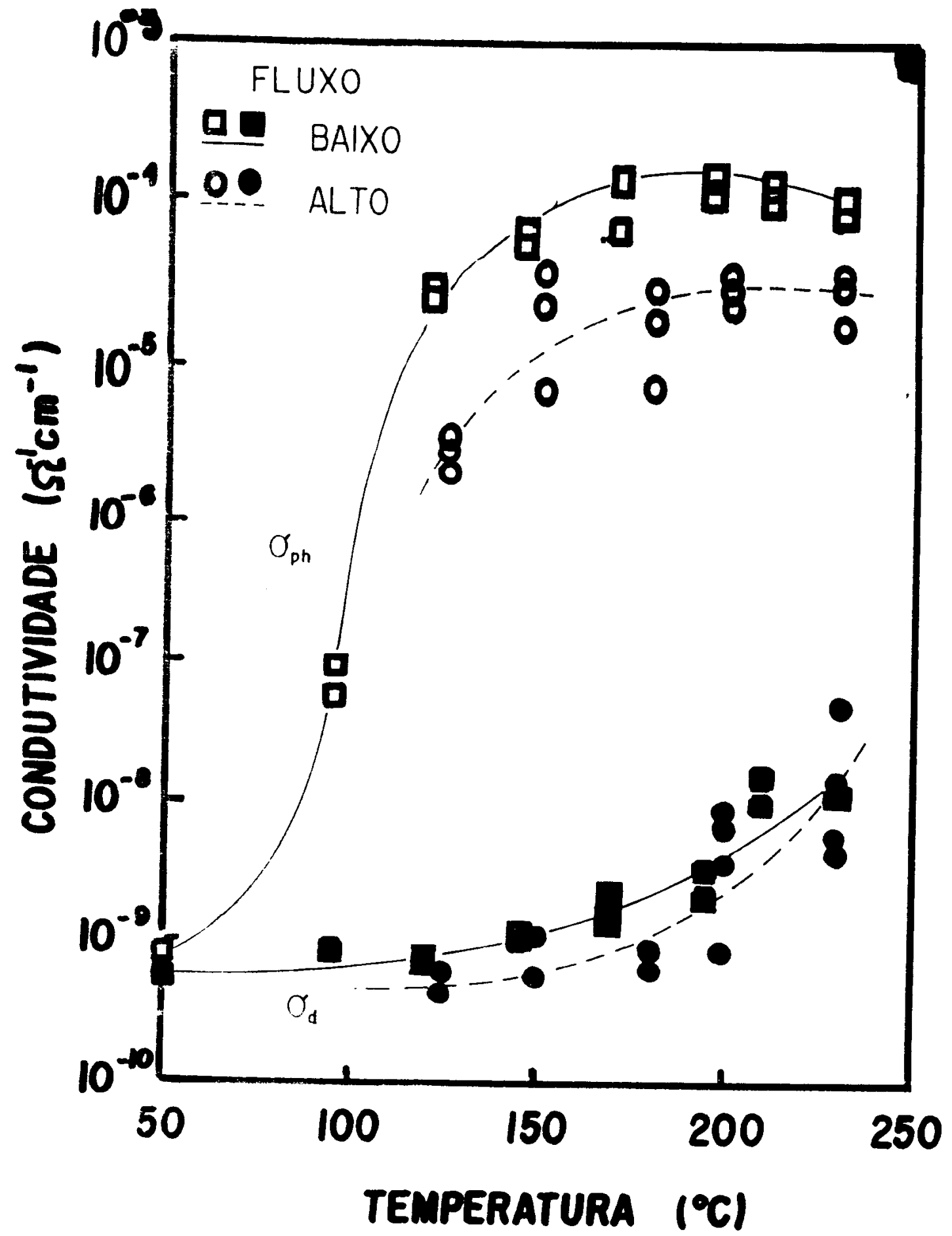

Figura 4.7. Medida da Condutividade no Escuro e da Fotocondutividade em Amostras depositadas a $60 \mathrm{~Hz}$ em Função da Temperatura do Substrato: a) para Fluxo de $\mathrm{SiH}_{4}$ de $10 \mathrm{ml} / \mathrm{min}$ : b) para Fluxo de $\mathrm{SiH}_{4}$ de $100 \mathrm{~mL} / \mathrm{min}$. Em ambos os casos a densidade de potência usada foi de $0.01 \mathrm{~W} / \mathrm{cm}^{2}$, e a pressão de deposição usada foi de 0.5 torr. 


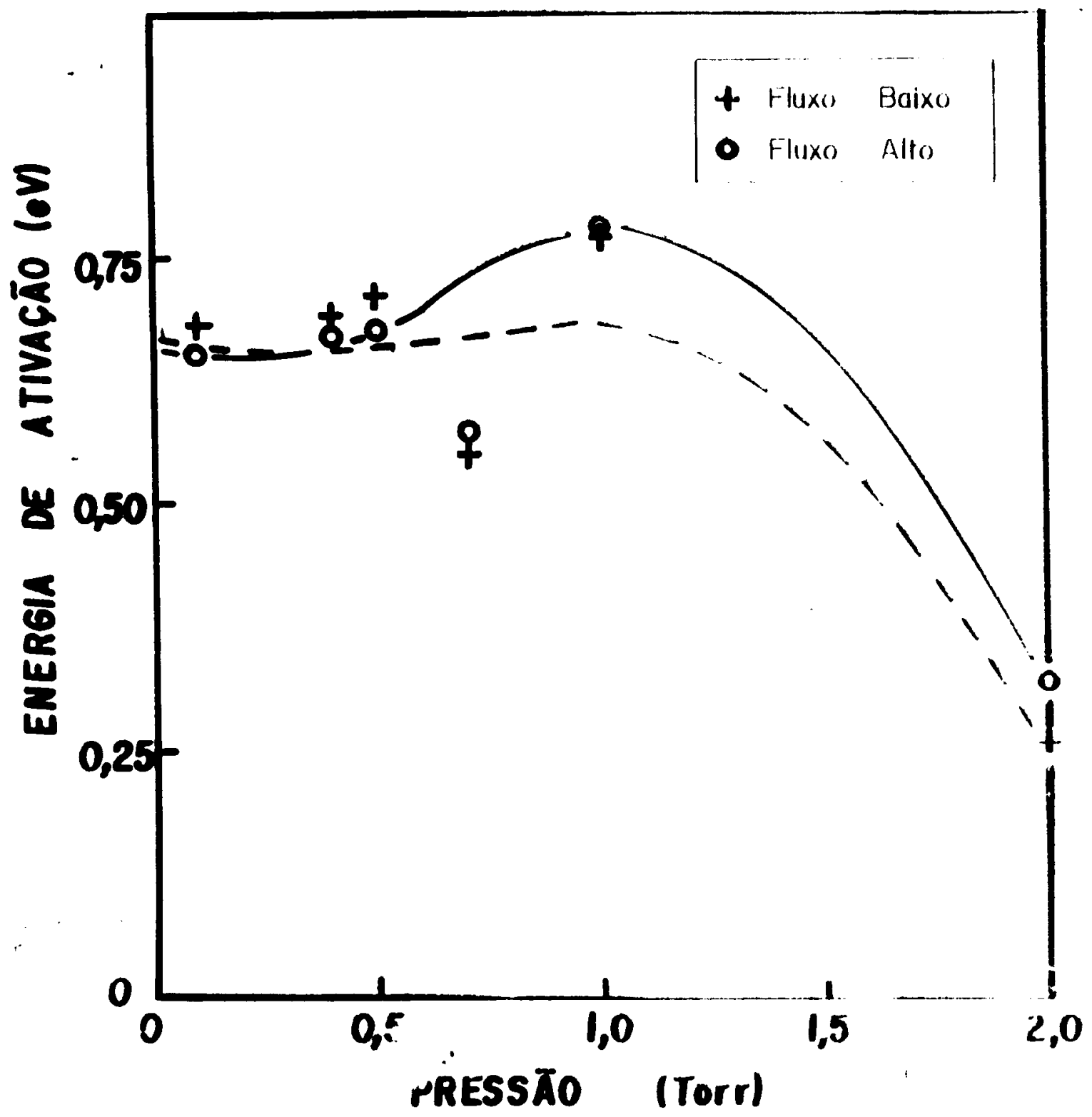

Figura 4.8. Medida da Energia de Ativação da Condutividade no Escuro de Amostras depositadas a 60 $\mathrm{Hz}$ em Função da Pressão de Deposição: a) para Fluxo de $\mathrm{SiH}_{4}$ de $10 \mathrm{ml} / \mathrm{min}$; b) para Fluxo de $\mathrm{SiH}_{4}$ de 100 $\mathrm{ml} / \mathrm{min}$. Em ambos os casos a densidade de potência usada foi de $0,01 \mathrm{~W} / \mathrm{cm}^{2}$, e a temperatura do substrato usada foi de $150^{\circ} \mathrm{C}$. 


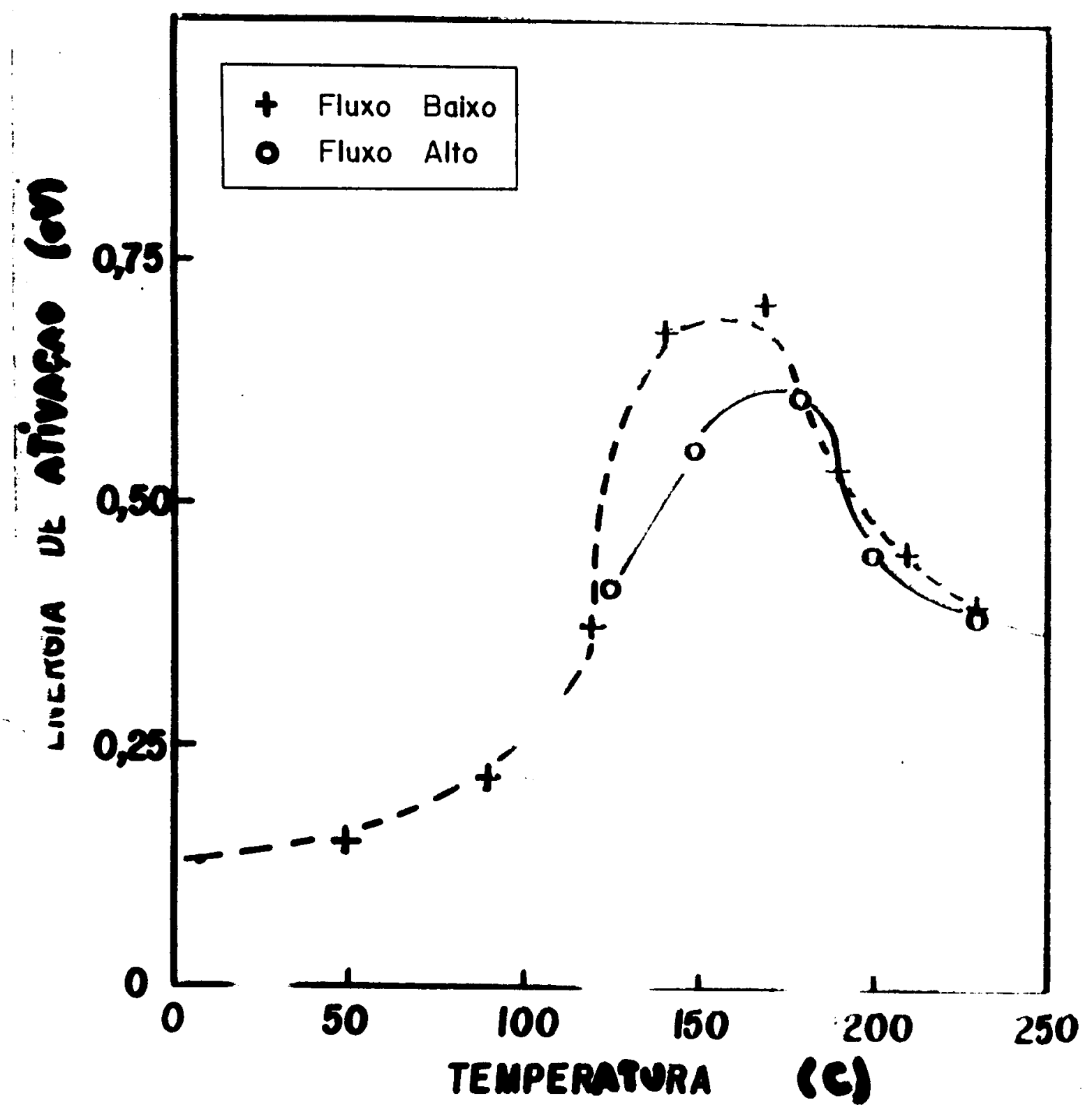

Figura 4.9. Medida de Energia de Ativação da Condutividade no Escuro de Amostras depositadas a 60 Hz em Função da Temperatura do Substrato: a) para Fluxo de $\mathrm{SiH}_{4}$ de $10 \mathrm{ml} / \mathrm{min}$; b) para Fluxo de $\mathrm{SiH}_{4}$ de 100 $\mathrm{ml} / \mathrm{min}$. Em ambos os casos a densidade de potência usada foi de $0,01 \mathrm{~W} / \mathrm{cm}^{2}$, e a pressão de deposiçăo usada foi de 0,5 torr. 


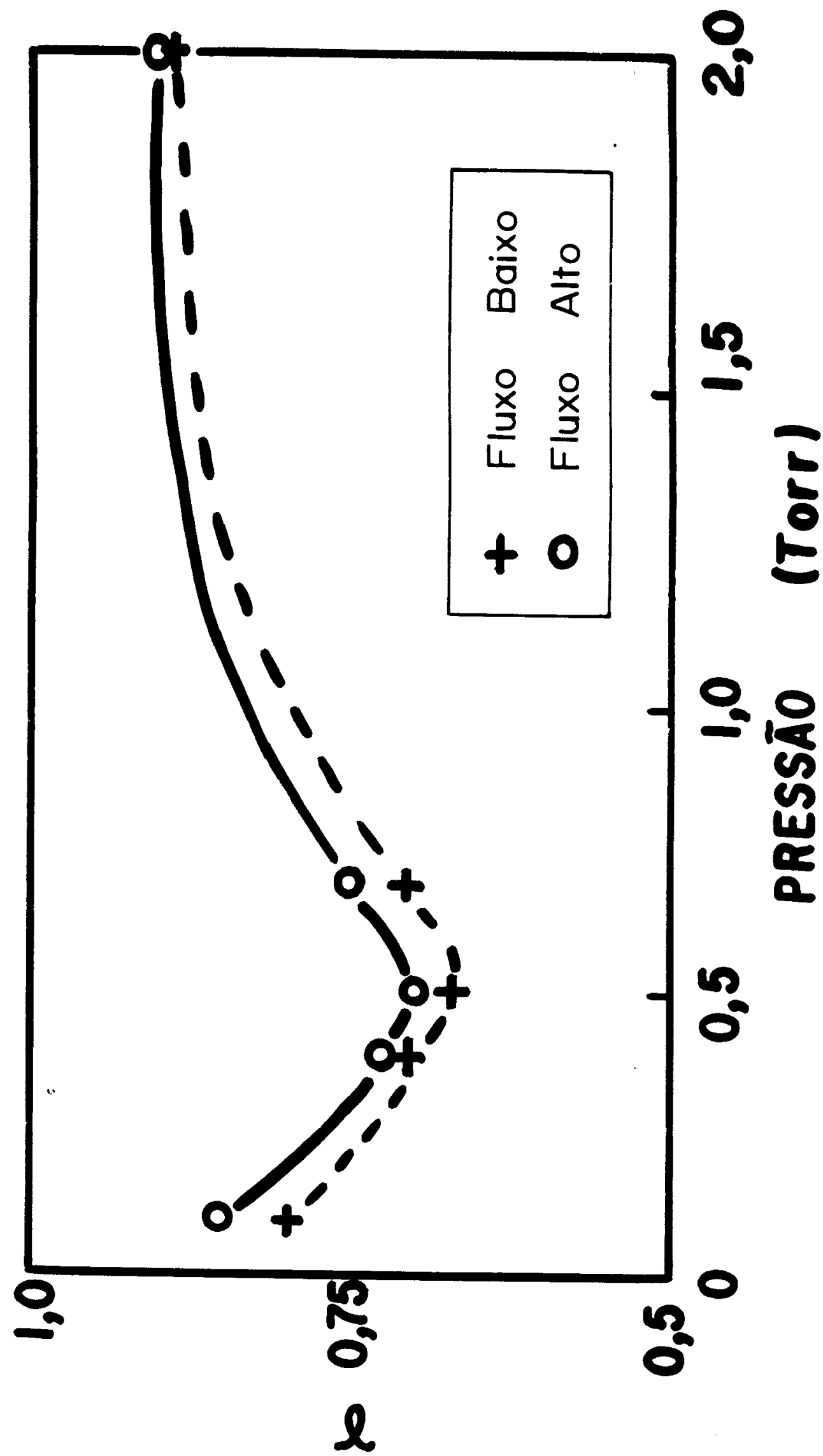

Figura 4.10. Medida do Fator $\gamma$ de Amostras depositadas a $60 \mathrm{~Hz}$ em Função da Pressão de Deposição: a) para Fluxo de $\mathrm{SiH}_{4}$ de $10 \mathrm{ml} / \mathrm{min}$ : b) para Fluxo de $\mathrm{SiH}_{4}$ de $100 \mathrm{ml} / \mathrm{min}$. Em ambos os casos a densidade de potência usada foi de $0.01 \mathrm{~W} / \mathrm{cm}^{2}$. e a temperatura do substrato usada foi de $150^{\circ} \mathrm{C}$. 


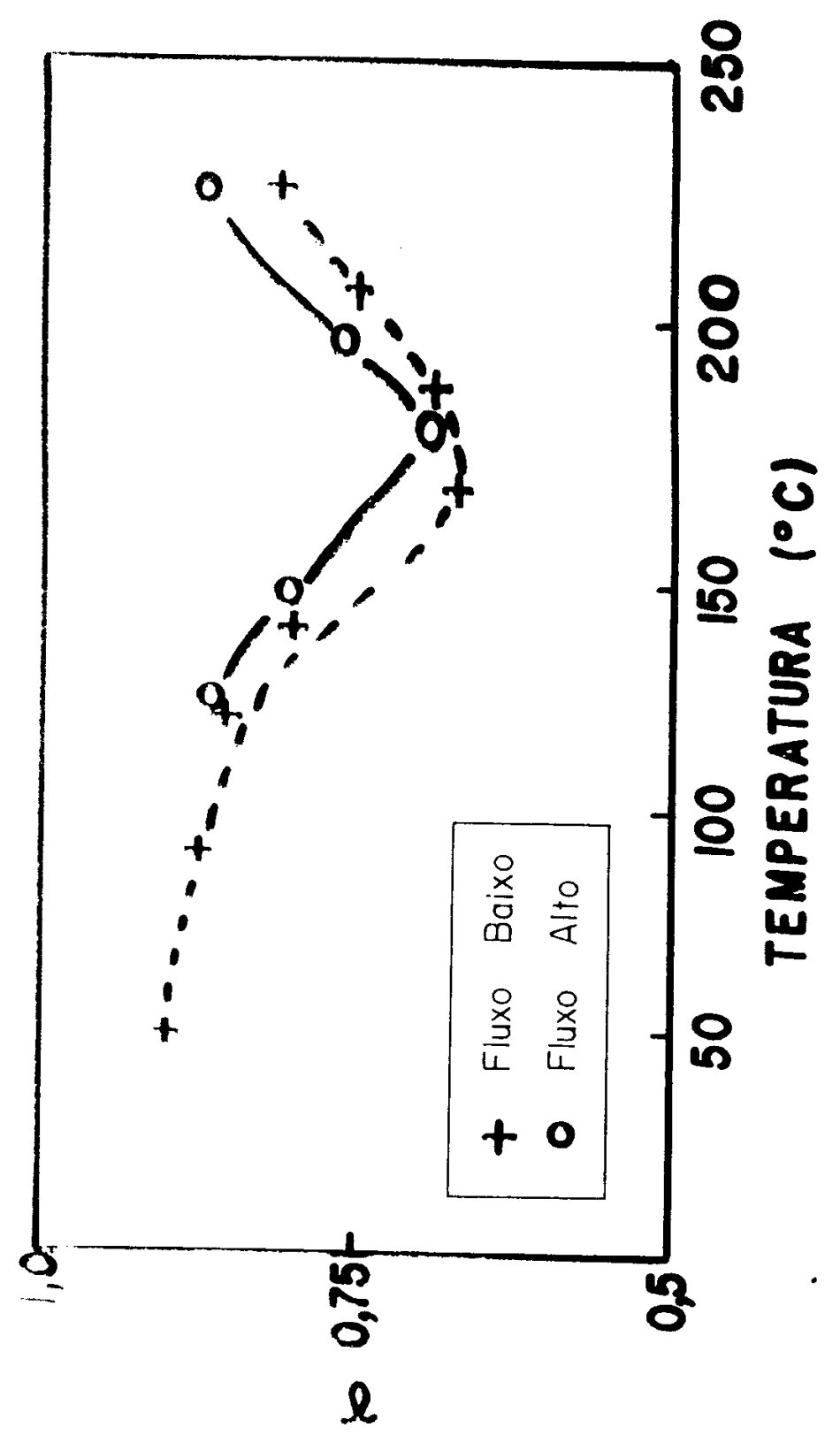

Figura 4.11. Medida do Fator $\gamma$ de Amostras Depositadas a $60 \mathrm{~Hz}$ em Função da Temperatura do Substrato: a) para Fluxo de $\mathrm{SiH}_{4}$ de $10 \mathrm{ml} / \mathrm{min}$; b) para Fluxo de $\mathrm{SiH}_{4}$ de $100 \mathrm{ml} / \mathrm{min}$. Em ambos os casos a densidade de potência usada foi de $0.01 \mathrm{~W} / \mathrm{cm}^{2}$. e a pressão de deposição usada foi de 0.5 torr. 
Por fim, na Figura 4.10. temos o comportamento do fator $\gamma$ (o qual relaciona a fotocondutividade com a intensidade da luz) em função da pressão de deposição, e na Figura 4.11. esta mesma propriedade em função da temperatura do substrato. Em ambos os casos, está mostrada a dependência com o fluxo. Para a amostra depositada por descarga luminescente a RF obtivemos um valor de $0,67 \pm 0.01$.

Como pode ser visto pela Figura 4.6. e pela Figura 4.7, a maior fotosensibilidade $F S$ é obtida apenas para pressão de 0,5 torr e temperatura do substrato entre $150-170^{\circ} \mathrm{C}$. Estas figuras mostram também que o fluxo baixo resulta em maior foto-sensibilidade do que o fluxo alto. Nestas condições o valor de $F S$ é de 7,5 $\times 10^{4} \pm$ $40 \%$; este valor é cerca de $20 \%$ menor do que para filmes depositados por descarga luminescente usando RF. Esta pequena diferença pode simplesmente refletir um gap óptico levemente maior e uma absorção menor nos filmes depositados usando-se 60 Hz. A Figura 4.7. mostra ainda uma queda acentuda na qualidade dos filmes quando depositados a temperaturas acima e abaixo da faixa de deposição ótima (150-170 $\left.{ }^{\circ} \mathrm{C}\right)$. Como exemplo, observamos que filmes depositados a $230{ }^{\circ} \mathrm{C}$ tem a foto-sensibilidade reduzida para menos do que $10^{4}$, e a energia de ativação para $0,3 \mathrm{eV}$.

Os resultados apresentados na Figura 4.8. e Figura 4.9. mostram que os melhores filmes depositados usando-se $60 \mathrm{~Hz}$ têm uma condutividade no escuro a temperatura ambiente de aproximadamente $10^{-9}(\Omega \mathrm{cm})^{-1}$ e um valor para a energia de ativação $E_{a}$ em torno de $0,7 \mathrm{eV}$. Os resultados das Figura 4.10. e Figura 4.11. indicam que o valor de $\gamma$ para os filmes depositados em condições de deposição ótimas é comparável àqueles obtidos para filmes depositados a RF. Isto sugere que em ambos os tipos de filme o mesmo tipo de trajetória de recombinação determina as fotocondutividades em estado estacionário.

Por fim, apresentamos os resultados das medidas do comprimento de difusão ambipolar. Como descrito na Seção 3.11., tais medidas foram feitas apenas em filmes com características especiais. Para filmes obtidos usando $60 \mathrm{~Hz}$ e fluxo baixo o valor de $L_{d}$ foi de $130 \mathrm{~nm}$; para filmes obtidos usando $60 \mathrm{~Hz}$ e fluxo alto encontramos 83 $\mathrm{nm}$; por fim, para filmes obtidos usando RF (método convencional) encontramos 130 
nm. Observamos que, em condições ótimas, encontramos valores próximos para 0 comprimento de difusão entre os filmes produzidos por RF e a $60 \mathrm{~Hz}$. O fato de que esta propriedade de transporte tenha valores próximos em ambos os casos nós atribuímos à estrutura similar dos dois casos, que foi comprovada através de medidas da estrutura dos filmes. Como foi salientado na Seção 4.2.5., o comprimento de difusão de um semicondutor é um parâmetro muito importante no projeto de dispositivos eletrônicos envolvendo tais materiais. Assim, a proximidade dos valores encontrados nos dois casos permite-nos dizer que a-Si:H produzido por descarga luminescente a $60 \mathrm{~Hz}$ constitui-se em um material eletrônico disponivel para a fabricação de dispositivos.

\subsection{Caracterização Óptica}

Por caracterização óptica, entendemos aqui apenas a determinação do gap óptico do material. As propriedades de transporte onde luz é usada foram descritas na Seção 4.2.; já as propriedades estruturais envolvendo luz serão descritas a seguir.

O gap de energia é com certeza um dos parâmetros mais importantes nos materiais semicondutores. No caso dos semicondutores amorfos a ordem de longo alcance não é mais mantida, e portanto a idéia de gap como entendida para materiais cristalinos não é mais válida. No entanto, pela existência de bandas de energia advindas das ligações químicas ${ }^{67}$, um gap de energia pode ser associado a esta estrutura de niveis.

Para os semicondutores amorfos, o cálculo do gap de energia $E_{g}$ que envolve um melhor significado fisico foi aquele introduzida por Tauc et al ${ }^{85}$. No cálculo para a obtenção desta energia, admite-se que:

i) o arranjo atômico no sólido amorfo como sendo uma rede perturbada do cristal correspondente;

ii) um dado volume $\mathrm{V}$ contém o mesmo número de átomos no estado amorfo $\mathrm{e}$ cristalino; 
iii) a perturbação que descreve a mudança do estado cristalino para o amorfo é tal que as funções de onda na banda de valência do estado amorfo sejam combinações lineares das funções de onda da banda de valência do estado cristalino; uma afirmação análoga é mantida para o estado cristalino.

Segundo estas hipóteses, e partindo da expressão geral da componente imaginária da constante dielétrica de um sólido sujeito a um campo eletromagnético oscilante de frequência $\omega$, obtém-se o seguinte resultado:

$$
\sqrt{E \alpha(E)}=\text { const } \times\left(E-E_{g}\right)
$$

onde $E=\hbar \omega$ é a energia do campo eletromagnético ao qual está sujeito o sólido, $\alpha(E)$ é o coeficiente de absorção do sólido, e a constante multiplicativa apenas um fator que devido ao caráter aproximativo das hipóteses não apresenta significado físico.

Para o $a$-Si: $\mathrm{H}, E_{g}$ admite valores entre 1,5 e $2,0 \mathrm{eV}$, isto é, correspondentes à parte visivel do espectro de radiação eletromagnética. Isto significa que, a partir de espectroscopia óptica na região de luz visível, é possível obter valores para $E_{g}$. Olhando para a Equação (4-45), observamos que o único obstáculo a ser transposto é a determinação do coeficiente de absorção $\alpha(E)$. Existem várias propostas para a obtenção do espectro de $\alpha$; aquela que parece-nos a mais completa, e cujas aproximações levam a um menor erro é a apresentada por Swanepoel ${ }^{86}$. Neste trabalho a expressão exata para a transmitância de um filme fino absorvedor de luz depositado sobre um substrato transparente é manipulada para gerar fórmulas fechadas para o cálculo do índice de refração e do coeficiente de absorção; além disto, um procedimento para calcular a espessura dos filmes é apresentada.

Todos os resultados da espessura e do gap de energia apresentados nesta Tese foram obtidos seguindo o procedimento sugerido por Swanepoel. Não vamos aqui discorrer sobre as equações usadas nestas determinações, já que trata-se de um artigo bastante conhecido e usado com frequência por todos os grupos de pesquisa da área. 
Diremos apenas que tal procedimento parte do espectro da transmitância dos filmes na faixa de 900 a $500 \mathrm{~nm}$; esta faixa inclui três regiões caracterísiticas:

i) região transparente, entre 900 a $800 \mathrm{~nm}$, com a qual é possível determinar o índice de refração do substrato;

ii) região de absorção fraca e média, entre 800 a $600 \mathrm{~nm}$; esta região apresenta como característica principal o surgimento de máximos e mínimos devido ao fenômeno de interferência; construindo envoltórias relativas a estes máximos e mínimos, é possível a partir da superior $\left(T_{M}\right)$ e da inferior $\left(T_{m}\right)$, e com o uso das suas respectivas expressões analíticas, determinar $n(E)$ e $\alpha(E)$ em toda essa região do espectro;

iii) região de absorção forte, entre 600 e $500 \mathrm{~nm}$, cujo espectro mostra claramente um decaimento exponencial; com os dados levantados a partir da região de absorção média e fraca, é possível determinar o índice de refração do filme na região de absorção forte; com a posse destas informações, mais a espessura dos filmes obtida a partir do padrão de interferência, determinamos $\alpha(E)$ também para esta região do espectro.

Um espectro de transmitância caracterísitico para o $a$-Si:H, indicando as regiões delineadas acima é mostrado na Figura 4.12..

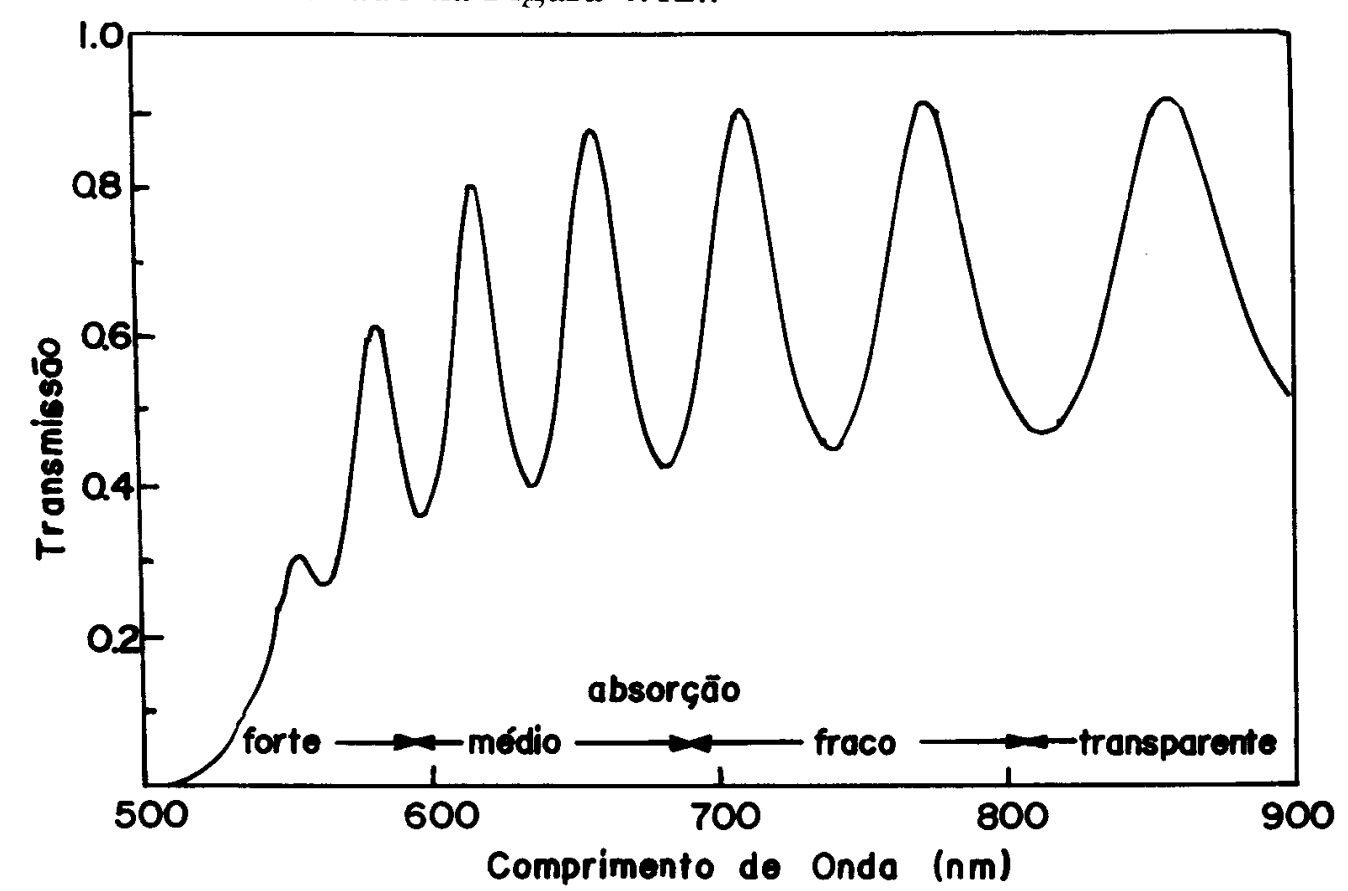

Figura 4.12. Espectro de Transmissão Caracteristico do $a$-Si:H na Região de Luz Visível. O Desenho Mostra Todas as Regiões de Interesse discutidas no Texto. 
Seguindo o procedimento explicitado acima conseguimos obter todo o espectro de $\alpha$ na região de interesse; assim, conseguimos construir um gráfico $(E \cdot \alpha)^{1 / 2} \times E$, e a partir da Equação (4-45) determinar o valor do gap de energia $E_{g}$.

Os espectros de transmitância usados para a determinação de $E_{g}$ foram obtidos num Espectrofotômetro Bomen Modelo FTIR.

\subsubsection{Resultados Experimentais}

Nós usamos a medida do gap óptico para ajudar a caracterização do reator, uma vez que a conjunção desta medida com a da energia de ativação permite estimar o valor do Nível de Fermi para o $a$-Si:H, como mostra a Equação (4-4). Com isto em mente, nós medimos o gap para amostras depositadas em várias pressões de deposição e temperaturas de substrato, com alto e baixo fluxo de gases. Assim, na Figura 4.13. observamos o comportamento do gap de energia em função da pressão de deposição, e na Figura 4.14. esta mesma propriedade em função da temperatura do substrato. Em ambos os casos, está mostrada a dependência com o fluxo. O gap de energia para o filme depositado por descarga luminescente a RF medido no mesmo equipamento no qual nossas amostras foram caracterizados é de $1,75 \pm 0.05 \mathrm{eV}$.

Os resultados apresentados nas Figura 4.13. e Figura 4.14. mostram que os valores do gap de energia situam-se entre 1,72 e 1,8 eV. Isto indica que o Nível de Fermi está localizado no meio do gap para estes filmes, conforme descrito pela Equação (4-4).

\subsection{Caracterização Estrutural}

Por caracterização estrutural entendemos a obtenção de propriedades que digam respeito a estrutura do material. Duas foram as propriedades escolhidas por nós para descrever a estrutura do $a-\mathrm{Si}: \mathrm{H}$ :

i) a densidade de estados no gap, que é uma medida da estrutura eletrônica do material, e é uma medida direta da quantidade de defeitos presentes no gap; 


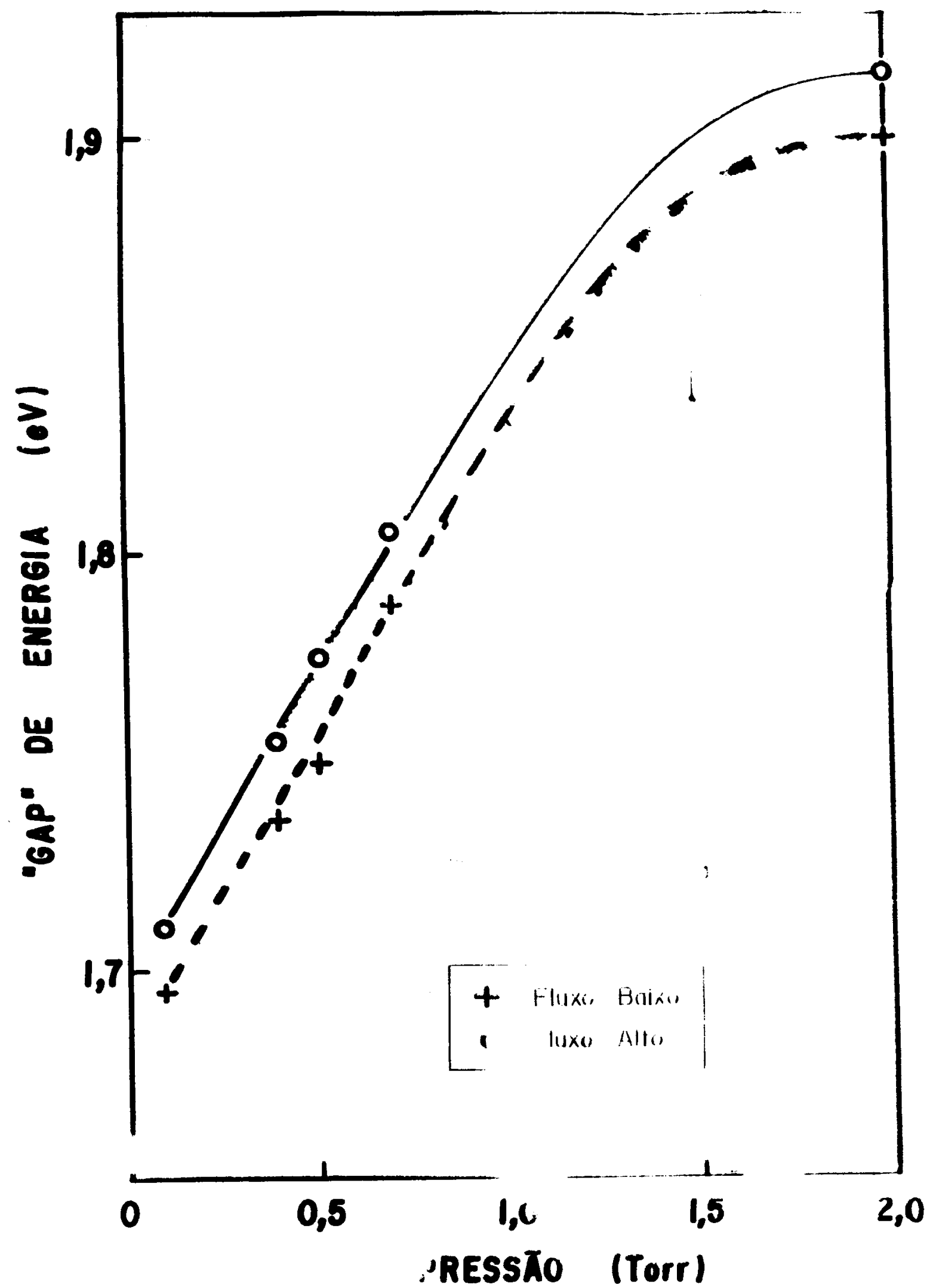

Figura 4.13. Medida do Gap Óptico de Amostras depositadas a $60 \mathrm{~Hz}$ em Funça da Pressão de Deposição: a) para Fluxo de $\mathrm{SiH}_{4}$ de $10 \mathrm{ml} / \mathrm{min}$; b) para Fluxo de $\mathrm{SiH}_{4}$ de $100 \mathrm{ml} / \mathrm{min}$. Em ambos os casos a densidade de potência usada foi de $0,01 \mathrm{~W} / \mathrm{cm}^{2}$, e a temperatura do substrato usada foi de $150^{\circ} \mathrm{C}$. 


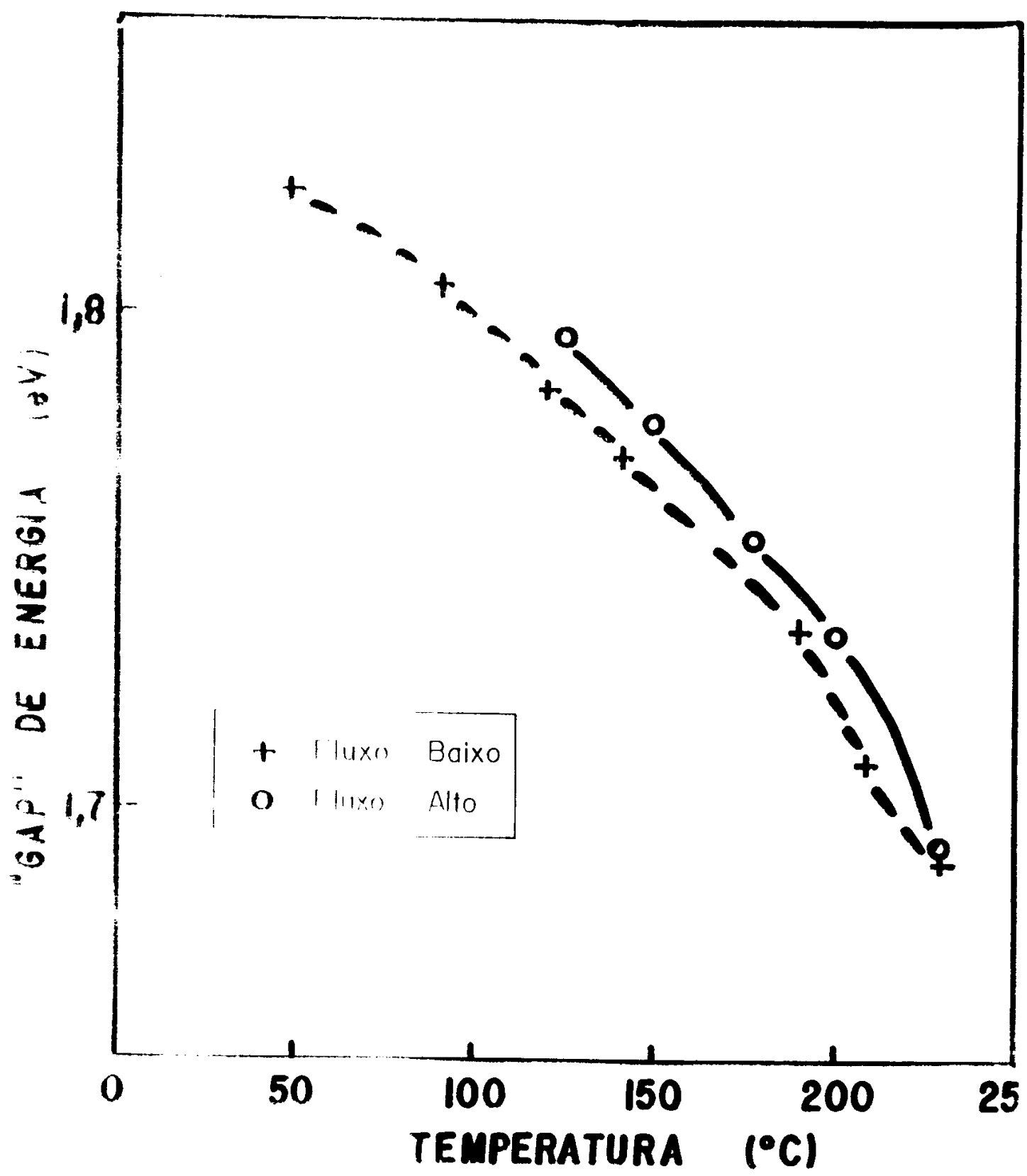

Figura 4.14. Medida do Gap Óptico de Amostras depositadas a $60 \mathrm{~Hz}$ em Função da Temperatura do Substrato: a) para Fluxo de $\mathrm{SiH}_{4}$ de $10 \mathrm{ml} / \mathrm{min}$ : b) para Fluxo de $\mathrm{SiH}_{4}$ de $100 \mathrm{ml} / \mathrm{min}$. Em ambos os casos a densidade de potência usada foi de $0.01 \mathrm{~W} / \mathrm{cm}^{2}$. e a pressão de deposição usada foi de 0.5 torr. 
ii) a quantidade de ligações $\mathrm{Si}-\mathrm{H}$ e $\mathrm{Si}-\mathrm{H}_{2}$ presentes no material, que é uma medida da quantidade de hidrogênio incorporado ao $a$-Si:H.

Vamos então agora descrever as técnicas por nós usadas para obter valores destas duas propriedades.

\subsubsection{Densidade de Estados no Gap}

A distribuição da densidade de estados $N(E)$ no gap de energia do $a$-Si:H é um parâmetro crucial na caracterização deste material do ponto de vista tecnológico, uma vez que ela determina as propriedades ópticas e elétricas na região de baixa absorção. A partir de $N(E)$ é possível determinar a densidade de estados DOS presentes no gap. Diferentes métodos têm sido usados para medir a $D O S^{87}$.

É bastante conhecido que a dependência espectral do coeficiente de absorção óptico $\alpha(E)$ está diretamente relacionada com a distribuição da densidade de estados $N(E)$; assim, a medida de $\alpha(E)$ é uma das indicadas para aferir a densidade de estados no gap, já que trata-se de uma técnica óptica de relativa facilidade de obtenção em laboratório. Conhecido o espectro do coeficiente de absorção, a densidade de estados é obtida a partir da deconvolução deste espectro. Valores de $\alpha$ nestes filmes podem ser determinados a partir de dados de transmitância e reflectância. Contudo, a determinação de $\alpha(E)$ a partir de dados de transmitância no $a$-Si:H é limitada a valores de $\alpha$ acima de $10^{2} \mathrm{~cm}^{-1}$, uma vez que para valores abaixo disto o espectro de transmissão mostra um padrão de interferência, o que torna impossível determinar $\alpha(E)$ com suficiente precisão. Assim, outras técnicas devem ser usadas para obter este importante parâmetro na região do infra-vermelho, onde a condição acima não é satisfeita. Resultados de espectroscopia foto-acústica (PAS) ${ }^{88}$ levam a valores de $\alpha$ acima de $1 \mathrm{~cm}^{-1}$, e usando-se espectroscopia de deflexão foto-térmica (PDS) ${ }^{89}$ alcança-se valores de até $10^{-1} \mathrm{~cm}^{-1}$. Técnicas diferentes envolvendo medidas de fotocondutividade tem sido aplicadas para estender o alcance de $\alpha$ até valores abaixo de $10^{-1} \mathrm{~cm}^{-1}$. Assim, sob determinada série de condições é possível derivar o espectro do coeficiente de absorção óptico a partir de medidas de fotocondutividade ${ }^{90}$. Estas condições estão listadas abaixo: 
i) se a iluminação e a geração do par elétron-buraco são uniformes ao longo do material, e a reflectância for desprezível, a fotocondutividade $\sigma_{p h}$ pode ser escrita como:

$$
\sigma_{p h}=e F \alpha\left(\eta \mu_{d} \tau\right)
$$

onde $F$ é o fluxo de fótons incidentes por unidade de área, $e$ é a carga do elétron, $\eta$ é a eficiência quântica para o processo de geração de fotoportadores, $\mu_{d}$ é a mobilidade de arraste do fotoportador dominante, e $\tau$ é o tempo de vida dos fotoportadores.

ii) na região de interesse, isto é, na faixa $1,2 \mathrm{eV} E\left[1,8 \mathrm{eV}\right.$, o produto $\eta \mu_{d} \tau$ pode ser considerado constante.

Estas hipótese são bem discutidas por Moddel et al ${ }^{\varphi 1}$. Em linhas gerais, a condição de iluminação uniforme é justificada se admitimos que a espessura $t$ do filme é tal que $\alpha t \quad l$, o que é observado na prática. Por outro lado, a respeito do produto $\eta \mu_{d} \tau$, é apresentada uma justificativa individual para cada um destas grandezas. No caso da eficiência quântica $\eta$ as possíveis variações com respeito à energia podem ocorrer devido aos processos de absorção levarem à não-produção do par elétronburaco próximo do limiar de condução; na região de energia de nosso interesse este efeito é muito pequeno, tornando-se forte para energias bem abaixo de $1,2 \mathrm{eV}$. No caso da mobilidade de arraste $\mu_{d}$ resultados experimentais indicam uma variação muito tênue com a energia. Por fim, no caso do tempo de vida $\imath$ o aparente acréscimo com a energia mostra que na verdade, a variação observada vem da dependência do tempo de vida com a densidade de fotoportadores.

A medida da fotocondutividade é feita através da medida da fotocorrente, aplicando-se uma determinada diferença de potencial constante $V$ entre dois eletrodos paralelos (comprimento $l$, separação entre contatos $d$ ). Nesta situação, a fotocondutividade é dada pela Equação (4-1). Igualando-se a Equação (4-46) com a Equação (4-1), e levando em conta a condição ii), temos que, caso a fotocorrente seja 
mantida constante quando a energia luminosa é variada, então o produto $\alpha F$ é constante, isto é:

$$
\alpha(E) \cdot F(E)=\text { constante. }
$$

Assim, caso conheçamos os valores de $\alpha_{0}$ e de $F_{0}$, respectivamente o coeficiente de absorção e o fluxo de fótons para uma determinada energia, medindo $F(E)$ necessário para manter fixa a fotocorrente, determinamos diretamente o espectro do coeficiente de absorção, já que:

$$
\alpha(E)=\frac{F_{0}}{F(E)} \alpha_{0}
$$

A medida de $\alpha_{0}$ pode ser obtida através de dados de transmitância, e $F_{0}$ pode ser medido com a ajuda do detetor usado no experimento. Devido a fotocorrente ser mantida constante ao longo de todo o experimento, esta técnica é conhecida como Constant Photocurrent Method (CPM). Como pôde ser visto, na técnica CPM o que medimos é o número de fótons necessário para manter a fotocorrente constante.

O dispositivo experimental para esta medida está mostrado na Figura 4.15.. Uma fonte de alimentação estabilizada controla a tensão que alimenta a lâmpada de filamento encapsulada com vapor de algum elemento halogênio. A luz emitida pela lâmpada com todas as energias passa inicialmente através de um monocromador para que apenas uma energia luminosa seja selecionada. A seguir, esta luz passa por um chopper para modular a sua intensidade. Um filtro é usado a seguir para eliminar harmônicos de ordem superiores gerados pelo monocromador. A seguir a luz passa por um divisor de feixe, tal que ela possa seguir por dois caminhos: um, paralelo à fonte de luz que incide sobre a amostra, e que é responsável pela geração da fotocorrente; e outro, perpendicular à fonte de luz que incide sobre o detetor, que é o responsável pela medida do fluxo de fótons que incide sobre a amostra. Tanto o sinal da fotocorrente, 
quanto 0 sinal do detetor são medidos cada um por urn lock-in. Alguns detalhes sobre cada um destes componentes são:

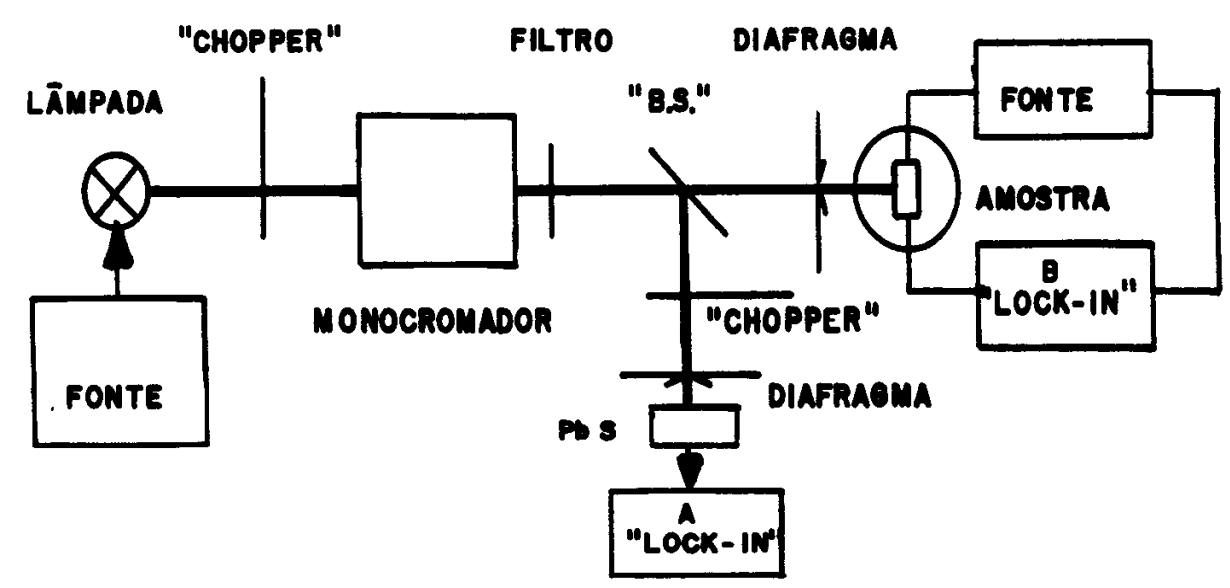

Figura 4.15. Dispositivo Experimental montado para a Técnica CPM (Constant Photocurrent Method)

i) a fonte de alimentação deve ter um ajuste fino o suficiente para que a fotocorrente medida no lock-in A seja mantida efetivamente constante.

ii) a freqüência do chopper deve ser suficientemente baixa, em torno de $13 \mathrm{~Hz}$, para que apenas o processo de excitação luminosa seja responsável pela fotocorrente.

iii) como divisor de feixe pode ser usado um espelho, apenas garantindo que a quantidade de fótons que incide sobre a amostra seja a mesma que incide sobre o detetor.

iv) como detetores duas possibilidades podem ser usadas: a) um detetor de $\mathrm{PbS}$ que cubra toda a região espectral de interesse. b) dois detetores, um de Ge que cobre a região entre 1,2 e 1,6 eV, e outro de $\mathrm{Si}$ que cobre a região entre 1,6 e 1,8 eV. Por motivo de facilidade, em nosso arranjo experiemental usamos o detetor de $\mathrm{PbS}$.

$O$ processo de medida baseia-se em manter constante a fotocorrente da amostra iluminada pela lâmpada. É conveniente iniciarmos a medida no valor mais baixo de 
energia; fixada esta energia no monocromador, ajusta-se a corrente na lâmpada para que a leitura no lock-in A tenha a máxima precisão; é este valor que deve ser controlado para que permaneça constante quando variamos a energia da luz. Neste ponto, anotamos o valor da tensão medida pelo lock-in $\mathrm{B}$, que lê o fluxo de fótons que incide sobre a amostra. Feito isto, alteramos 0 valor da energia luminosa através do monocromador, e ajustamos a corrente da lâmpada até que a leitura no lock-in A seja a mesma que a anterior; quando isto ocorrer, anotamos o valor da leitura no lock-in $\mathrm{B}$. Este procedimento é repetido até que todo o espectro de energia seja varrido; quando isto ocorrer, teremos como resultado final o espectro do fluxo de fótons $F$ necessário para manter a fotocorrente na amostra constante; como pode ser facilmente observado, a medida de $F$ é convertida em Volt, obtida no detetor; isto não causa problemas, já que como pode ser visto pela Equação (4-48) necessitamos apenas do valor relativo do fluxo de fótons $F$ em relação a um certo valor $F_{0}$ em cuja energia o valor do coeficiente de absorção $\alpha_{0}$ seja conhecido. Usando então a Equação (4-48) conseguimos construir o espectro do coeficiente de absorção na região entre 1,2 e 1,8 eV. Um espectro do coeficiente de absorção característico na região de interesse é mostrado na Figura 4.16.

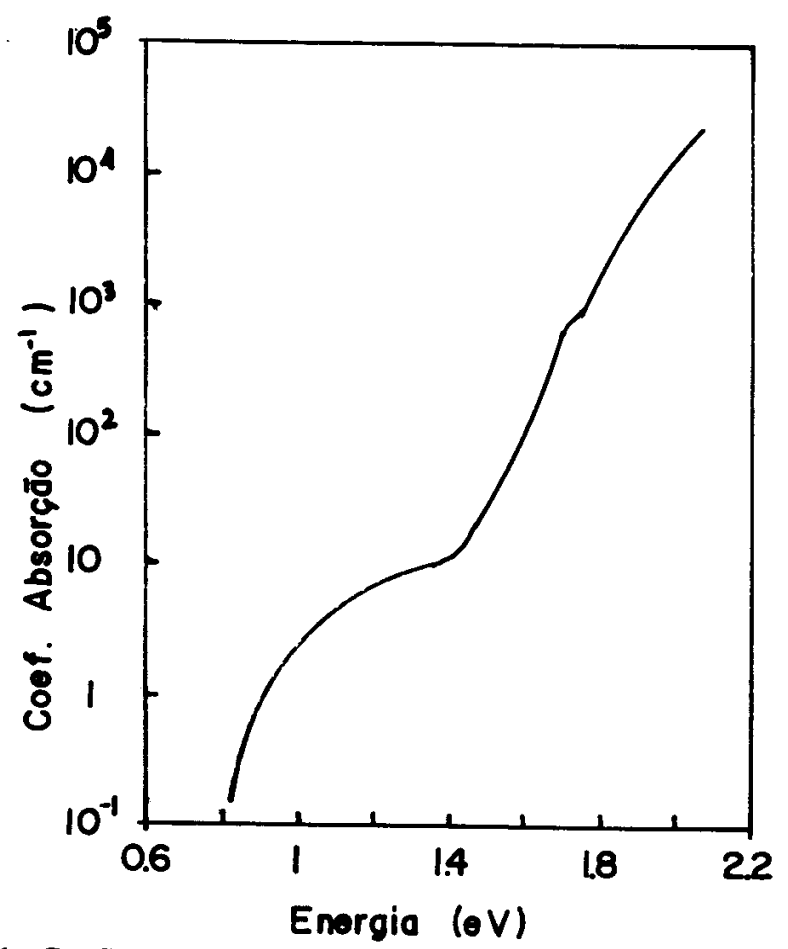

Figura 4.16. Espectro do Coeficiente de Absorção Caracterísitico do a-Si:H obtido pela técnica CPM (Constant Photocurrent Method) na Região do Infra-Vermelho Próximo. 
Como pode ser visto, tal espectro apresenta duas regiões caracterísiticas:

i) a primeira, para energias mais baixas, com características claras de saturação, a qual está relacionada com a absorção de estados de defeitos no gap;

ii) a segunda, para energias mais altas, com um crescimento exponencial de $\alpha$ em relação a $E$, correspondendo a absorção de estados presentes na cauda do gap.

O comportamento exponencial desta segunda região é dado por:

$$
\alpha_{\exp }(E)=\alpha_{0} \exp \left(\frac{E}{E_{0}}\right)
$$

onde $\alpha_{0}$ é o coeficiente de absorção usado para ajustar a curva, e $E_{0}$ é a Energia de Urbach.

O número de defeitos presentes no gap pode ser estimado separando a absorção de estados de defeito da absorção exponencial da cauda. O excesso na absorção óptica devido à absorção dos estados de defeitos no gap é dada por:

$$
\alpha_{\operatorname{exc}}(E)=\alpha(E)-\alpha_{\exp }(E) \text {, }
$$

onde $\alpha(E)$ corresponde ao espectro completo do coeficiente de absorção.

De uma regra de soma, o número de defeitos $N_{d}$ está relacionado com a absorção por:

$$
N_{d}=\frac{c n m}{2 \pi^{2} \hbar^{2} e_{s}^{* 2}} \int \alpha_{e x c}(E) d E,
$$

onde $c$ é a velocidade da luz, $n$ é o índice de refração do $a$-Si:H, $m$ é a massa do elétron, e $e^{*}$ é a carga efetiva do defeito. Os limites de integração estendem-se de 0 até a energia na qual a característica exponencial termina, isto é, em torno de 1,6 eV. 
Usando correções de campo local para determinar a carga efetiva92, e valores aproximados para o índice de refração, obtemos o seguinte resultado para o número de defeitos:

$$
N_{d}=7,9 \times 10^{15} \int \alpha_{e x c}(E) d E .
$$

Como vemos, a técnica $C P M$ fornece um excelente método para determinar o número de defeitos presentes no gap, já que através dela obtemos $\alpha(E)$ na região de energias inferiores àquela correspondente ao gap (subgap absorption). A partir do espectro do coeficiente de absorção obtido por esta técnica determinamos $\alpha_{0}$ e $E_{0}$, e então chegamos a uma expressão fechada para $\alpha_{\text {exp. }}$. A partir dai, usando técnicas numéricas, calculamos uma expressão para $\alpha_{e x c}$, e então determinamos $N_{d}$ usando a Equação (4-52).

\subsubsection{Número de Ligações Si-H e Si-H}

É bastante conhecido que o hidrogênio desempenha um papel fundamental nas propriedades do $a$-Si:H. Acredita-se que sua função seja a de passivar as ligações insaturadas (dangling bonds) inerentes dos processos de obtenção do $a$-Si puro, resultando em alterações nas propriedades ópticas e elétricas deste material. Assim, o conhecimento do teor de hidrogênio incorporado ao filme é uma informação da maior relevância para determinar as propriedades do $a-\mathrm{Si}: \mathrm{H}$.

Uma das identificações mais diretas do papel do hidrogênio na matriz amorfa de silício vem através de estudos da absorção óptica na região do infra-vermelho. $O$ espectro de infra-vermelho fornece informações a respeito da energia e da intensidade das vibrações entre átomos ligados. Tipicamente estes espectros cobrem a faixa de 2,5 a 4,0 $\mu \mathrm{m}$, e mostram a magnitude da absorção de dipolo.

A frequência de um modo de absorção fundamental no infra-vermelho depende de ambas, a massa do dipolo oscilante e da força do oscilador da ligação entre os átomos que perfazem o dipolo. Isto implica que para dipolos a frequência do oscilador ocorrerá apenas sobre uma faixa estreita e fixa. Assim, medindo a frequência 
característica na qual a absorção no infra-vermelho ocorre, a identidade das espécies moleculares pode ser determinada.

$\mathrm{O}$ espectro de infra-vermelho de filmes de $a$-Si:H mostra principalmente os modos vibracionais característicos das várias possibilidades de ligações entre silício e hidrogênio no sólido, isto é, $\mathrm{SiH}, \mathrm{SiH}_{2}$, e $\mathrm{SiH}_{3}$. Como está bem esquematizado no trabalho de Brodsky et al 93 as absorções à $2000 \mathrm{~cm}^{-1}$ e à $630 \mathrm{~cm}^{-1}$ são devido aos modos de stretching e wagging respectivamente. As bandas existentes entre 800 e 900 $\mathrm{cm}^{-1}$ são devido aos modos vibracionais bending da estrutura $\mathrm{SiH}_{2}$. Além disso, existe uma banda a $2100 \mathrm{~cm}^{-1}$ correspondente também a um modo vibracional de bending.

Enquanto os modos vibracionais devido à ordem de curto alcance local são evidentes no espectro do $a$-Si:H, os modos vibracionais devido à matriz amorfa de $\mathrm{Si}$, isto é, a ligação $\mathrm{Si}-\mathrm{Si}$, também podem ocorrer, mas geralmente são fracos. Estes modos não apresentam momentos de dipolo de primeira ordem. e neles a absorção de infravermelho ocorre apenas por processos de segunda ordem.

Além disso, para caracterizar espécies ou por modos locais, ou por modos estruturais, o número de espécies absorvedoras pode também ser determinado a partir de dados de infra-vermelho.

Resumindo, com os espectros de infra-vermelho do $a-\mathrm{Si}: \mathrm{H}$, é possivel chegar a dois tipos de conclusão:

i) a partir do número de onda correspondente a um pico, identifica-se de que forma átomos de hidrogênio estão ligados ao átomo de silício;

ii) a partir da forma do pico, determina-se a concentração de um determinado tipo de ligação silício-hidrogênio 93.94 .95 .

Neste trabalho nós usamos os espectros de infra-vermelho como uma medida da qualidade dos filmes depositados. É bastante conhecido que filmes de qualidade eletrônica apresentam a dominância de estruturas do tipo $\mathrm{SiH}^{96}$; isto significa que nestes filmes espera-se uma presença marcante do modo vibracional de stretching a $2000 \mathrm{~cm}^{-1}$. Por outro lado, filmes de má qualidade eletrônica revelam a presença de estruturas $\mathrm{SiH}_{2}$, indicando a existência de modos vibracionais de bending a 800, 900, e 
$2100 \mathrm{~cm}^{-1}$. Desta forma, com uma simples olhada no espectro de infra-vermelho do $a$ $\mathrm{Si}: \mathrm{H}$ é possivel chegar a uma conclusão sobre a qualidade destes filmes; caso eles apresentem estruturas na região $800-900 \mathrm{~cm}^{-1}$ com certeza suas propriedades elétricas serão deficientes. A identificação do pico a $2100 \mathrm{~cm}^{-1}$ é mais difícil, já que o modo de stretching tem um de seus modos localizado a $2000 \mathrm{~cm}^{-1}$, bastante próximo daquele modo bending. Mesmo assim, o deslocamento do pico em direção a qualquer uma das estruturas é evidente nos espectros.

Além desta análise qualitativa, a partir do espectro de infra-vermelho é possivel obter também a concentração de hidrogênio ligado a um determinado modo; a concentração de hidrogênio nos filmes é obtida integrando o modo wagging e multiplicando por uma constante de proporcionalidade ${ }^{97}$, tal que:

$$
N_{H}=1,6 \times 10^{19} \mathrm{j} \frac{\alpha(\omega)}{\omega} d \omega
$$

onde $\alpha(\omega)$ é o coeficiente de absorção em função do número de onda, e a integral é feita apenas sobre o pico do modo wagging, centrado a $640 \mathrm{~cm}^{-1}$. De maneira análoga, é possivel quantificar o número de ligações $\mathrm{SiH}$ e $\mathrm{SiH}_{2}$ que contribuem para o modo stretching e bending, respectivamente. Seguindo o procedimento usado por Brodsky et $a l^{93}$, o número de ligações $\mathrm{SiH}, N_{S}, \mathrm{e} \mathrm{SiH}_{2}, N_{B}$, é dado por:

$$
\begin{aligned}
& N_{S}=A \times 1,72 \times 10^{20} \int_{S} \frac{\alpha(\omega)}{\omega} d \omega \\
& N_{B}=A \times 8,6 \times 10^{19} \int_{B} \frac{\alpha(\omega)}{\omega} d \omega,
\end{aligned}
$$

onde $A$ é uma constante que depende apenas da constante dielétrica do sólido, e os índices $\mathrm{S}$ e $\mathrm{B}$ indicam que as integrais devem ser feitas apenas nos picos de stretching

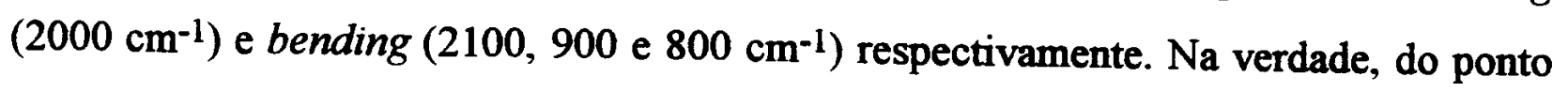


de vista de resultado, o que interessa-nos é a razão entre $N_{S}$ e $N_{B}$. Chamando esta razão de $R$, temos:

$$
R=\frac{N_{B}}{N_{S}}
$$

Para a obtenção do coeficiente de absorção, medimos o espectro de transmitância no infra-vermelho na faixa entre $4000 \mathrm{e} 400 \mathrm{~cm}^{-1}$. Estas medidas foram feitas em filmes de $a$-Si:H depositadas sobre silício policristalino com apenas a face sobre a qual ocorreu o depósito polida; a outra foi mantida com certa rugosidade. As medidas foram realizados um Espectrofotômetro Bomen do tipo FTIR. Para converter os dados de transmitância para coeficiente de absorção nós usamos o procedimento indicado por Freeman e Paul95.

\subsubsection{Resultados Experimentais}

A Figura 4.17. mostra o espectro do coeficiente de absorção na região do infravermelho próximo $(0,8-2,0 \mathrm{eV})$, obtido pela técnica $C P M$, como descrito na Seção 4.4.1.. Os três tipos de amostras foram medidos no mesmo sistema experimental.

Através destes dados foi possível calcular a energia de Urbach $E_{0}$ e a densidade de estados presentes no gap, como indicado pela Equação (4-52). Para a amostra depositada a $60 \mathrm{~Hz}$ e fluxo alto $E$ vale $58 \mathrm{meV}$; para a amostra depositada a $60 \mathrm{~Hz}$ e fluxo baixo, $54,5 \mathrm{meV}$; por fim para amostra depositada pelo método convencional (RF), $46 \mathrm{meV}$. Como pode ser facilmente observado por estes dados as melhores amostras obtidas em nosso laboratório apresentam uma energia de Urbach cerca de 10 $\mathrm{meV}$ maior do que a amostra obtida de forma convencional. Por outro lado, a amostra depositada fora dos parâmetros ótimos tem uma energia de Urbach quase o dobro em relação à amostra obtida por RF.

IFSC - SERVICODE BIBLIOTECA E 


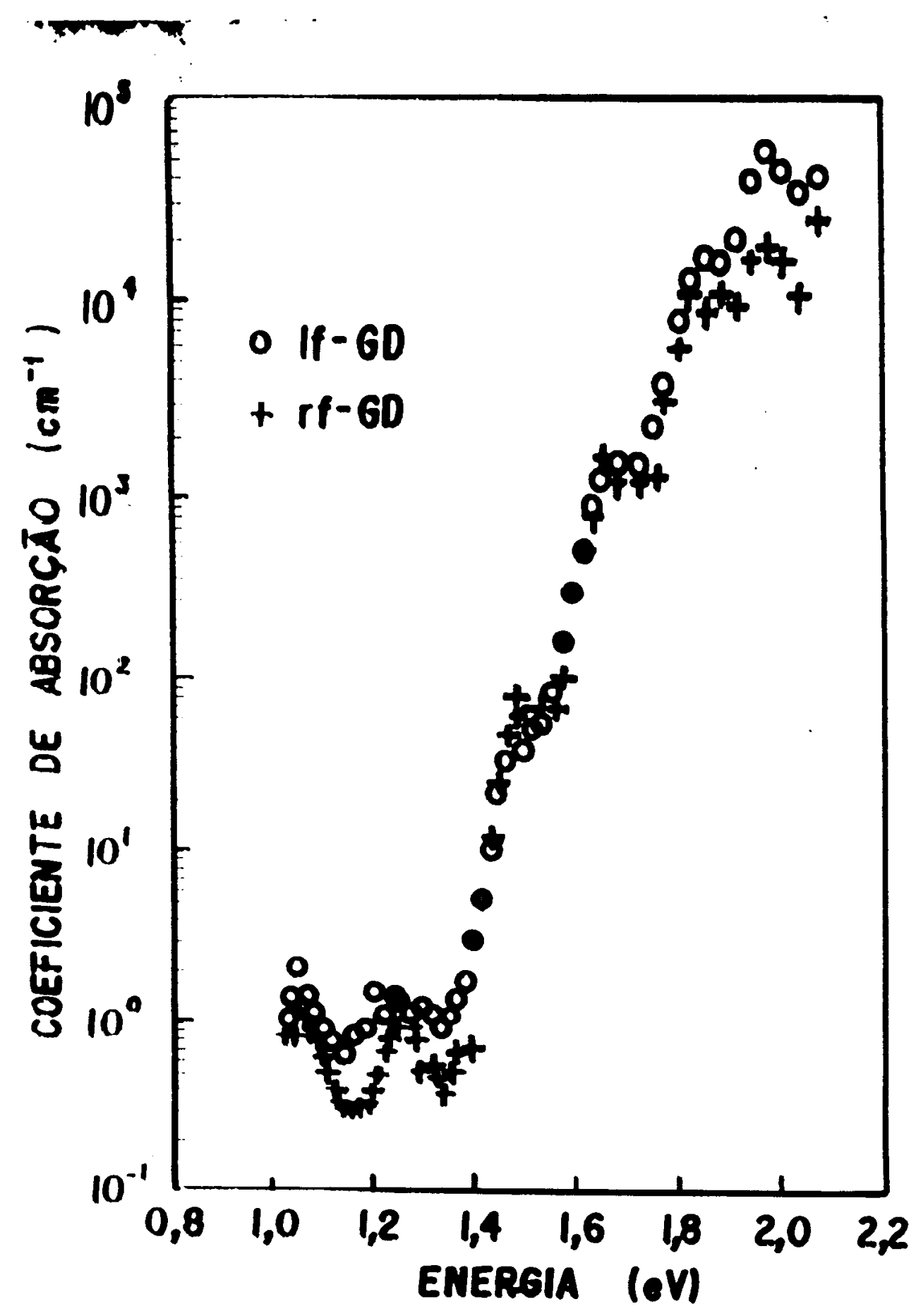

Figura 4.17. Espectro do Coeficiente de Absorção obtido pela Técnica CPM (Constant Photocurrent Method): a) para Amostra depositada a $60 \mathrm{~Hz}$ com Fluxo de $\mathrm{SiH}_{4}$ a $10 \mathrm{ml} / \mathrm{min}$; b) para Amostra depositada a $60 \mathrm{~Hz}$ com Fluxo de $\mathrm{SiH}_{4}$ a $100 \mathrm{ml} / \mathrm{min}$; c) para Amostra depositada a RF. No caso das amostras depositadas a $60 \mathrm{~Hz}$, a pressão de deposição usada foi de 0.5 torr, e a temperatura do substrato $170{ }^{\circ} \mathrm{C}$. 
Estes valores refletem-se na densidade de defeitos no gap, onde observamos que a amostra depositada com parâmetros ótimos tem a mesma ordem de grandeza que a amostra obtida de forma convencional, ao passo que a amostra depositada fora da otimização apresenta uma densidade de defeitos cerca de duas ordens de grandeza maior.

Os resultados da espectroscopia no infra-vermelho apenas confirmam as medidas elétricas e ópticas. A Figura 4.18. mostra as concentrações de $\mathrm{SiH}$ e $\mathrm{SiH}_{2} \mathrm{em}$ função da pressão, enquanto que a Figura 4.19. mostra a dependência desta mesma propriedade com a temperatura. Em ambos os casos, está mostrada a dependência com o fluxo. Como pode ser visto, para temperaturas fora da faixa $150-170{ }^{\circ} \mathrm{C}$ a concentração de $\mathrm{SiH}$ diminui, enquanto que a concentração de $\mathrm{SiH}_{2}$ aumenta. Isto está de acordo com a idéia de que radicais $\mathrm{SiH}_{2}$ são responsáveis pela baixa qualidade elétrica dos filmes.

A Figura 4.20. mostra o espectro de transmissão no infra-vermelho para os três tipos de amostras descritas acima. Olhando atentamente para a Figura 4.20. observamos que o modo wagging $\left(640 \mathrm{~cm}^{-1}\right)$ parece ser independente da forma de obtenção da amostra ${ }^{98.97}$, já que em todos os casos ele mostra-se fixo naquela frequência. Um pico de intensidade pequena na faixa de $840-890 \mathrm{~cm}^{-1}$ é observado nas amostras depositadas em nosso laboratório (parâmetros ótimos ou não); picos nesta mesma faixa de frequência também são observados por outros autores ${ }^{98}$.

Estes picos são atribuidos a grupos $\mathrm{SiH}_{2}$ isolados, que tem um modo vibracional a $875 \mathrm{~cm}^{-1}$, ao invés de possiveis grupos $\left(\mathrm{SiH}_{2}\right)_{\mathrm{n}}$ provenientes de alguma polimerização, cujos modos bending semelhantes a tesouras ${ }^{96}$ localizam-se a 845 e $890 \mathrm{~cm}^{-1}$. Estes filmes também mostram um pequeno pico a $980 \mathrm{~cm}^{-1}$, que foi identificado como um complexo oxigênio-hidrogênio, que sugere algum tipo de contaminação da câmara por oxigênio ${ }^{96}$. Dentro do modo stretching $\left(2000-2100 \mathrm{~cm}^{-1}\right)$, a razão $R$ entre as áreas dos picos centrados a $2000 \mathrm{~cm}^{-1}$ e $2090 \mathrm{~cm}^{-1}$ é normalmente adotada como um parâmetro da microestrutura do material; encontramos $R$ igual a 0,3 para amostra depositada a $60 \mathrm{~Hz}$ com fluxo alto, 0,25 para amostra depositada a $60 \mathrm{~Hz}$ 
e fluxo baixo, e 0,065 para amostra depositada por RF de modo convencional; daí podemos ver que $R$ é cerca de 4 vezes menor no caso dos filmes depositados por RF do que naqueles obtidos a $60 \mathrm{~Hz}$; estes números são provavelmente devido à presença de grupos $\mathrm{SiH}_{2}$ isolados nos filmes obtidos a $60 \mathrm{~Hz}$.

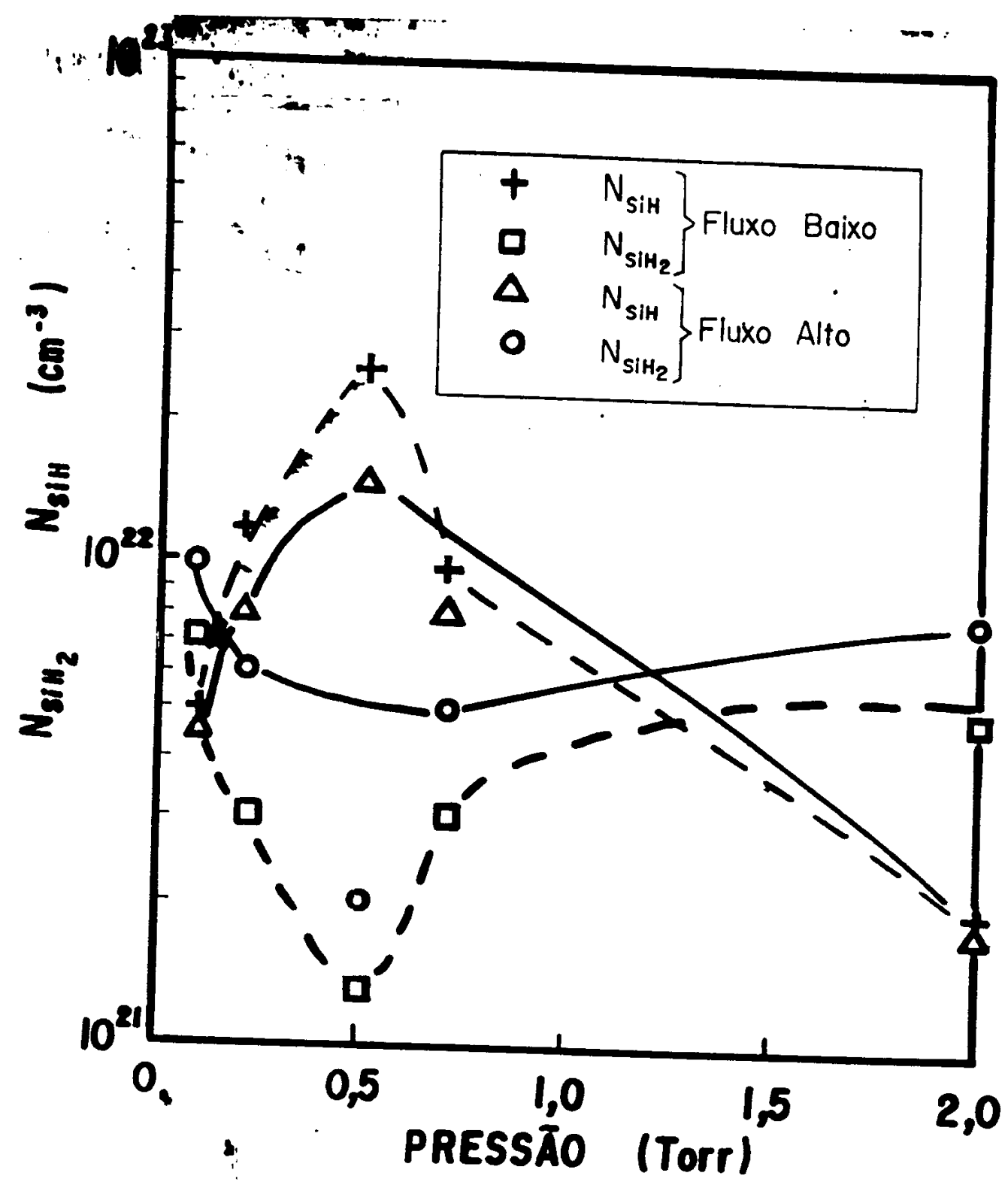

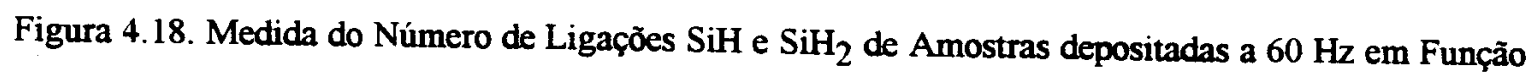
da Pressão de Deposição: a) para Fluxo de $\mathrm{SiH}_{4}$ a $10 \mathrm{ml} / \mathrm{min}$; b) para Fluxo de $\mathrm{SiH}_{4}$ a $100 \mathrm{ml} / \mathrm{min}$. Em ambos os casos, a densidade de potência usada foi de $0,01 \mathrm{~W} / \mathrm{cm}^{2}$, e a temperaratura do substrato foi de $150^{\circ} \mathrm{C}$. 


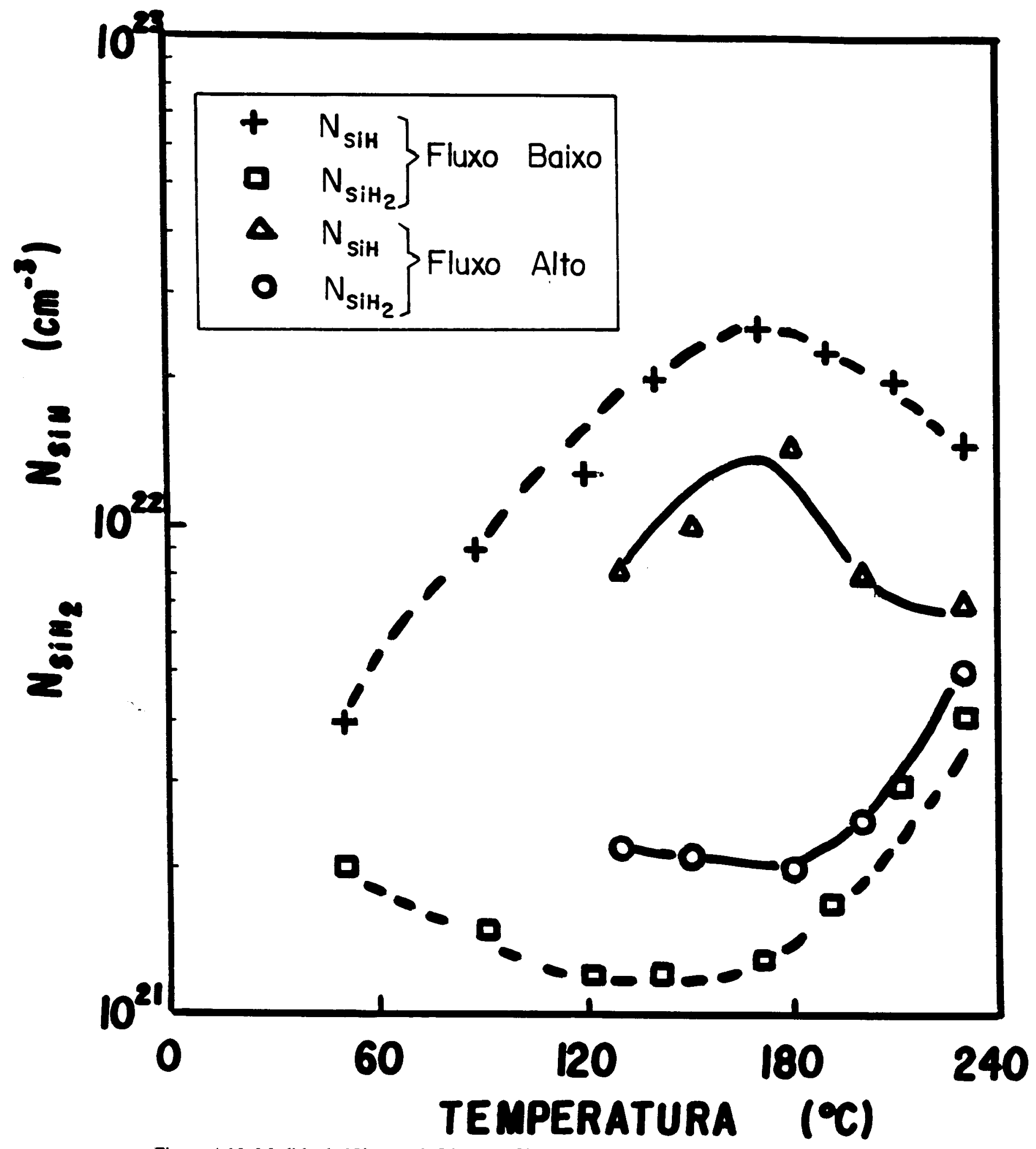

Figura 4.19. Medida do Número de Ligações $\mathrm{SiH}$ e $\mathrm{SiH}_{2}$ de Amostras depositadas a $60 \mathrm{~Hz}$ em Função da Temperatura do Substrato: a) para Fluxo de $\mathrm{SiH}_{4}$ a $10 \mathrm{ml} / \mathrm{min}$; b) para Fluxo de $\mathrm{SiH}_{4}$ a $100 \mathrm{ml} / \mathrm{min}$. Em ambos os casos. a densidade de potência usada foi de $0,01 \mathrm{~W} / \mathrm{cm}^{2}$, e a pressão de deposição foi de 0,5 torr. 


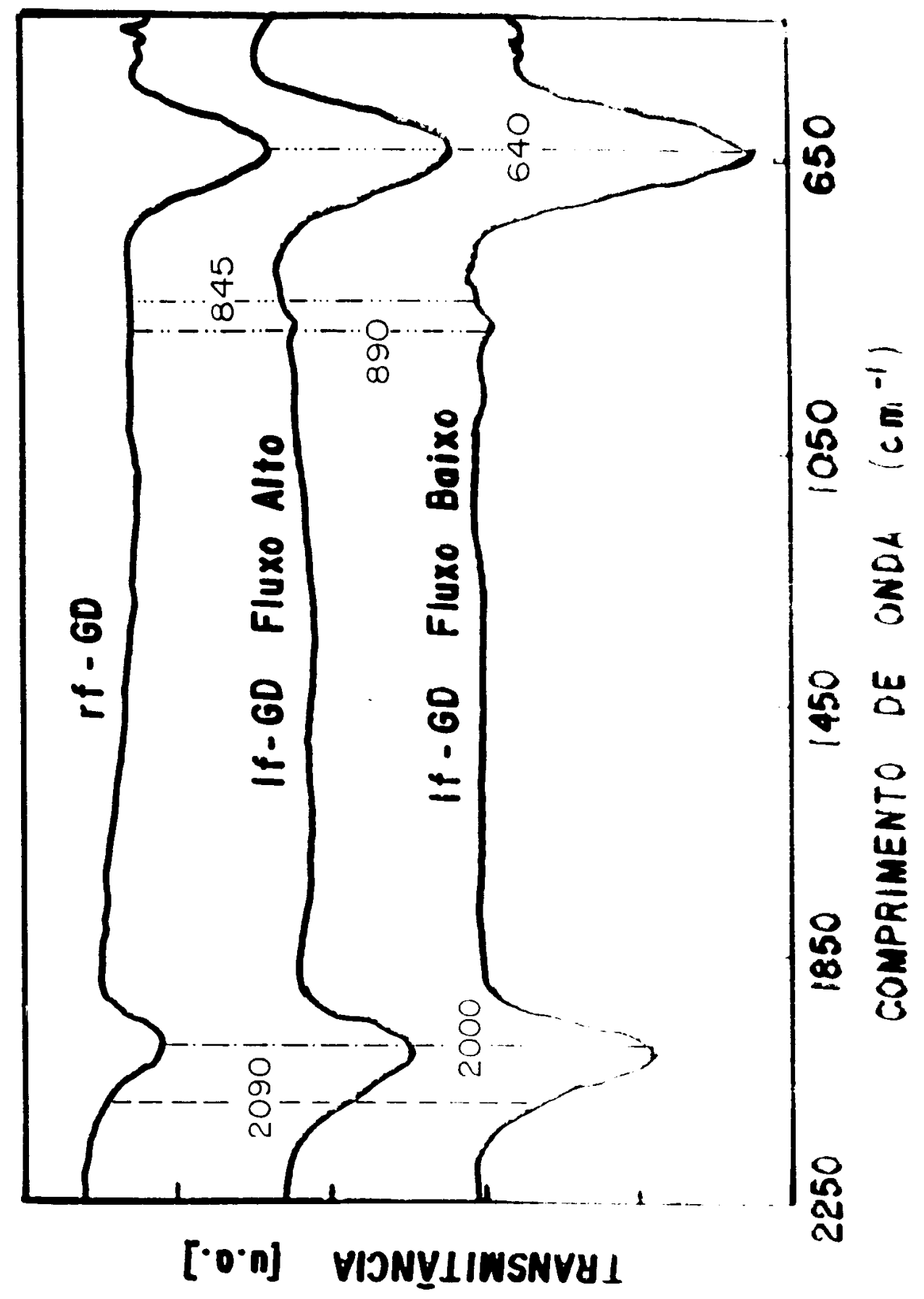

Figura 4.20. Espectro de Transmissão no Infra-Vermelho Distante: a) para Amostra depositada a 60 $\mathrm{Hz}$ com Fluxo de $\mathrm{SiH}_{4}$ a $10 \mathrm{ml} / \mathrm{min}$ : b) para Amostra depositada a $60 \mathrm{~Hz}$ com Fluxo de $\mathrm{SiH}_{4}$ a $100 \mathrm{ml} / \mathrm{min}$ : c) para Amostra depositada a RF. Nas Amostras depositadas a $60 \mathrm{~Hz}$ a densidade de potência usada foi de 0.01 W/cm². a temperatura do substrato foi de $170^{\circ} \mathrm{C}$, e a pressão de deposição foi de 0.5 torr. 
Para finalizar, a razão entre os picos relativos ao modo wagging $\left(640 \mathrm{~cm}^{-1}\right) \mathrm{em}$ ambos os filmes depositados a $60 \mathrm{~Hz}$ é cerca de $70 \%$ maior do que no caso de filmes obtidos por RF; a nossa interpretação é de que pode haver uma grande força de oscilador incomum ao modo stretching nos filmes obtidos a $60 \mathrm{~Hz}$; outros autores ${ }^{98}$ argumentam que a força do oscilador diminui com o aumento do teor de hidrogênio em filmes obtidos por sputtering por RF recozidos abaixo de $200{ }^{\circ} \mathrm{C}$. Em filmes depositados por descarga luminescente a $60 \mathrm{~Hz}$ nós observamos o comportamento oposto. Deve ser notado também, a título de comparação, que Tochitani et al ${ }^{99}$ cresceram filmes de alta qualidade usando baixas frequências cuja razão entre os modos stretching e wagging parecem ser similares àqueles obtidos para filmes depositados a RF 101 .

\subsection{Otimização dos Parâmetros de Deposição}

Os resultados mostrados ao longo desta Seção permitem que possamos chegar a uma conclusão definitiva sobre as condições de deposição ótimas, nas quais filmes de $a$-Si:H depositados por descarga luminescente a $60 \mathrm{~Hz}$ tenham propriedades eletrônicas. A caracterização do reator indicou que existe uma faixa estreita de pressão de deposição e temperatura do substrato na qual é possível obter filmes de $a$-Si:H de boa qualidade. Esta faixa corresponde a uma pressão de 0,5 torr e uma temperatura de substrato de $170^{\circ} \mathrm{C}$.

Até agora temos dado atenção apenas às propriedades do filme, sem preocuparmo-nos com a viabilidade econômica do processo que temos estudado. Um parâmetro tecnológico importante para a caracterização do reator é a taxa de deposição. Nesta linha, nós estudamos o comportamento desta propriedade em função da pressão de deposição e a temperatura do substrato. É desejável que tenhamos a taxa de deposição mais alta possível para que o filme possa obter uma determinada espessura no menor tempo possível; naturalmente, é desejável também que os filmes tenham propriedades elétricas e ópticas que indiquem seu uso para dispositivos eletrônicos. A dependência da taxa de deposição com a pressão de deposição está 
mostrada na Figura 4.21., enquanto que sua dependência com a temperatura do substrato está mostrada na Figura 4.22.. Nas respectivas figuras está mostrada a dependência com 0 fluxo de gases (alto ou baixo). Inicialmente estes resultados indicam que a taxa de deposição é maior para o fluxo maior, como era de se esperar. Além disto, nas faixas de pressão e temperatura usadas nas deposições observamos que a taxa de deposição é maior para temperaturas maiores do que $200 \mathrm{C}$ pressões maiores do que 1 torr. Porém, estas temperatura e pressão (principalmente a pressão) localizam-se nas faixas onde a foto-sensibilidade é muito baixa; isto significa que, embora a máxima taxa de deposição ocorra acima de $200{ }^{\circ} \mathrm{C}$ e 1 torr, os filmes não poderão ser depositados com estes paràmetros, já que isto acarretaria em filmes de péssima qualidade. Uma outra caracterísitica da taxa de deposição de filmes depositados usando $60 \mathrm{~Hz}$ é que ela é ligeiramente inferior à taxa de deposição nominal de filmes depositados usando-se RF.

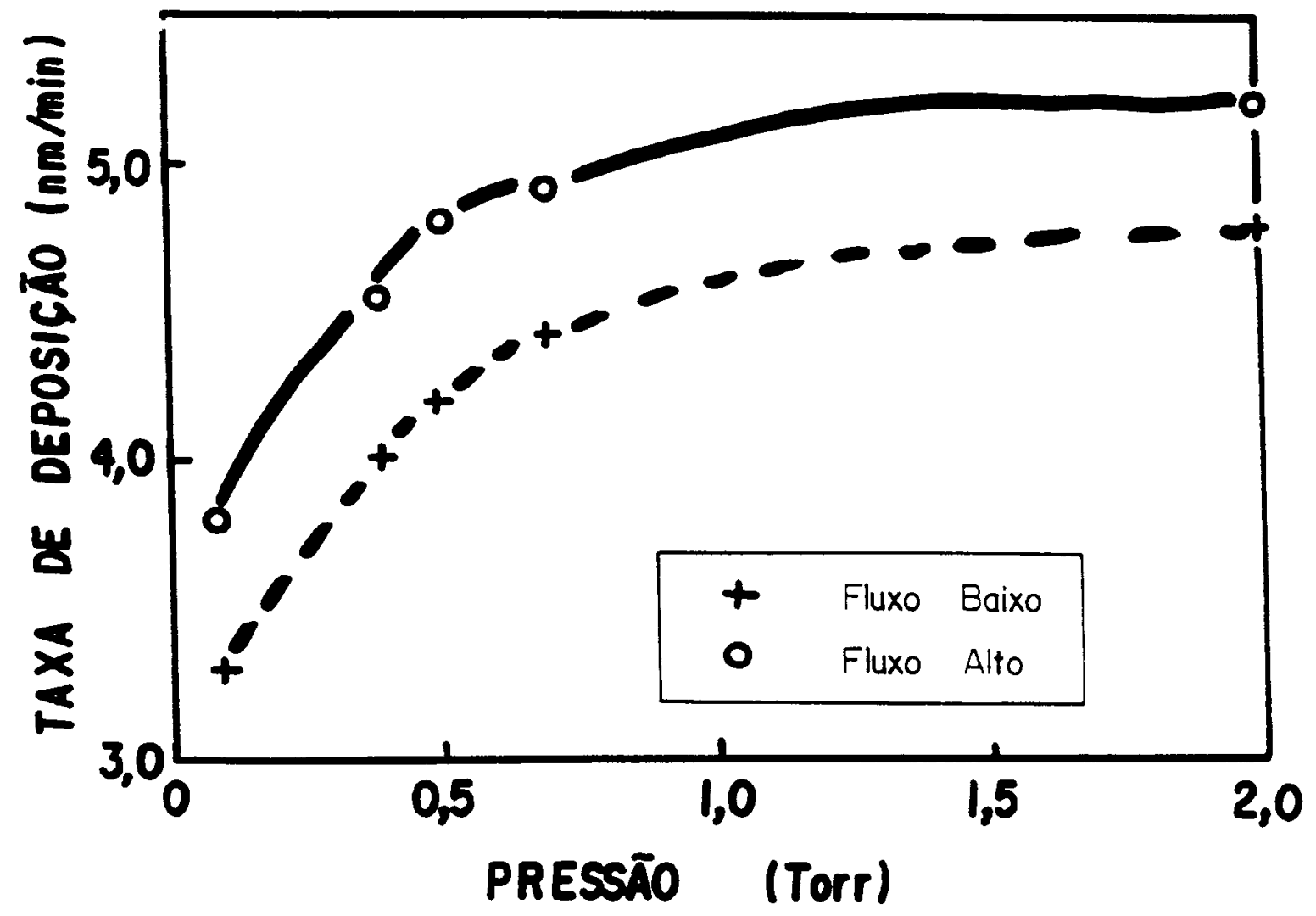

Figura 4.21. Medida da Taxa de Deposição de Amostras depositadas a $60 \mathrm{~Hz}$ em Função da Pressão de Deposição: a) para Fluxo de $\mathrm{SiH}_{4}$ a $10 \mathrm{ml} / \mathrm{min}$ : b) para Fluxo de $\mathrm{SiH}_{4}$ a $100 \mathrm{ml} / \mathrm{min}$. Em ambos os casos, a densidade de potência usada foi de $0.01 \mathrm{~W} / \mathrm{cm}^{2}$, e a temperaratura do substrato foi de $150^{\circ} \mathrm{C}$. 


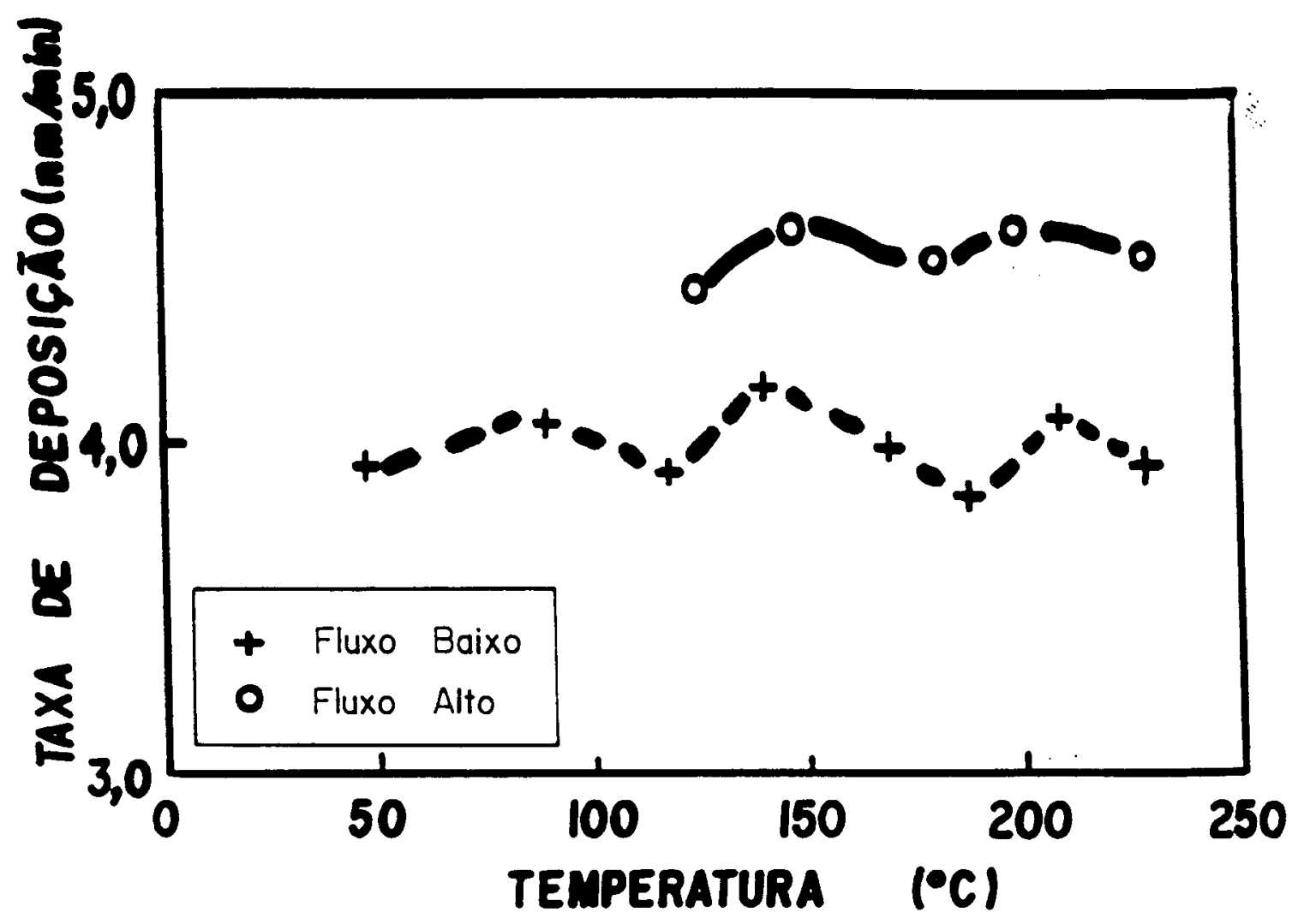

Figura 4.22. Medida da Taxa de Deposição de Amostras depositadas a $60 \mathrm{~Hz}$ em Função da Temperatura do Substrato: a) para Fluxo de $\mathrm{SiH}_{4}$ a $10 \mathrm{ml} / \mathrm{min}$ : b) para Fluxo de $\mathrm{SiH}_{4}$ a $100 \mathrm{ml} / \mathrm{min}$. Em ambos os casos. a densidade de potência usada foi de $0.01 \mathrm{~W} / \mathrm{cm}^{2}$. e a pressão de deposição foi de 0.5 torr.

Desta forma é preciso compatibilizar uma taxa de deposição alta (relativa às demais) com propriedades ópticas e elétricas ótimas para os filmes. Nesta região a taxa de deposição, apesar de não obter seu valor máximo, admite um valor satisfatório. É nesta faixa, então, que consideraremos que nossos filmes têm propriedades ótimas. 


\section{SEÇÃO 5}

\section{QUADRO RESUMO COMPARATIVO DOS RESULTADOS EXPERIMENTAIS}

\subsection{Introdução}

Nesta Seção mostramos um quadro resumo dos resultados obtidos para os filmes depositados por descarga luminescente a $60 \mathrm{~Hz}$, comparando-os com filmes depositados pela técnica convencional (descarga luminescente a RF). Nesta linha, apresentamos uma tabela, comparando os resultados obtidos em nosso reator, considerando fluxo de gases alto e baixo, com medidas similares feitas em amostras depositadas pela técnica convencional. No final da Seção, apresentamos uma justificativa das diferenças entre os dois tipos de processo. descarga luminescente a 60 $\mathrm{Hz}$ e usando RF.

\subsection{Comparação entre os Processos $60 \mathrm{~Hz}$ e RF}

Para uma melhor visualização dos resultados mostrados na Seção 4, construímos a Tabela 5.1., onde ali estão colocados todas as medidas feitas nos três tipos de filmes estudados. Na Tabela 5.1. os resultados para filmes depositados a 60 $\mathrm{Hz}$, tanto fluxo alto como fluxo baixo, correspondem a filmes obtidos em condições de deposição ótimas.

Na Tabela 5.1. podemos comparar os resultados da foto-sensibilidade, da fotocondutividade, da condutividade no escuro, da energia de ativação, e do fator $\gamma$ para os três tipos de filme. Estes resultados mostram que a estas propriedades são comparáveis entre os filmes produzidos por RF e a $60 \mathrm{~Hz}$ em condições ótimas. A Tabela 5.1. apresenta ainda resultados da Energia de Urbach, da densidade de defeitos, do fator de microestrutura $R$, e da porcentagem de hidrogênio incorporada aos filmes. Olhando com atenção para estes resultados, observamos que a Energia de Urbach é cerca de $25 \%$ maior nos filmes depositados a $60 \mathrm{~Hz}$, o que é traduzido na 
densidade de defeitos superior em filmes depositados por este processo. O fator de microestrutura $R$ também apresenta o mesmo comportamento, indicando a existência de mais átomos de hidrogênio ligados segundo a forma $\mathrm{SiH}_{2}$ nos filmes depositados a $60 \mathrm{~Hz}$ se comparado aos depositados a RF. Por fim, a Tabela 5.1. mostra valores do gap óptico e do comprimento de difusão ambipolar. Tanto uma propriedade quanto outra apresentam resultados comparáveis entre os dois processos, o que indica, principalmente no caso do comprimento de difusão ambipolar, uma caracterísitica de material eletrônico para filmes depositados a $60 \mathrm{~Hz}$.

Tabela 5.1. Propriedades dos Melhores Filmes depositados a $60 \mathrm{~Hz}$ para Fluxo de $\mathrm{SiH}_{4}$ a 10 e 100 $\mathrm{ml} / \mathrm{min}$. comparados com Filmes depositados a RF.

\begin{tabular}{|c|c|c|c|c|}
\hline Propriedades & Unidade & $\begin{array}{c}60 \mathrm{~Hz} \text { alto } \\
\text { fluxo }\end{array}$ & $\begin{array}{c}60 \mathrm{~Hz} \text { baixo } \\
\text { fluxo }\end{array}$ & $\mathrm{RF}$ \\
\hline $\mathrm{T}_{\mathrm{s}}$ & $\mathrm{C}$ & 170 & 170 & 240 \\
$\sigma_{\mathrm{d}}$ & $(\Omega \mathrm{cm})^{-1}$ & $0,7 \times 10^{-9}$ & $1,3 \times 10^{-9}$ & $1 \times 10^{-9}$ \\
$\sigma_{\mathrm{nh}}$ & $(\Omega \mathrm{cm})^{-1}$ & $2 \times 10^{-5}$ & $1 \times 10^{-5}$ & $1 \times 10^{-5}$ \\
$\mathrm{FS}$ & - & $3 \times 10^{+}$ & $7,5 \times 10^{4}$ & $1 \times 10^{4}$ \\
$\mathrm{E}_{\mathrm{a}}$ & $\mathrm{eV}$ & 0,7 & 0,65 & 0.71 \\
$\gamma$ & - & 0,66 & 0,85 & 0,67 \\
$\mathrm{E}_{0}$ & $\mathrm{meV}$ & 58 & 54,5 & 46 \\
$\mathrm{~N}_{\mathrm{d}}$ & $\mathrm{cm}-3$ & $2 \times 10^{16}$ & $3 \times 10^{16}$ & $1 \times 10^{16}$ \\
$\mathrm{R}$ & - & 0,3 & 0,25 & 0,065 \\
$\% \mathrm{H}$ & $\% \mathrm{em} \mathrm{átomos}$ & 16 & 12 & 8 \\
$\mathrm{E}_{\mathrm{g}}$ & $\mathrm{eV}$ & 1,73 & 1,80 & 1,75 \\
$\mathrm{~L}_{\mathrm{d}}$ & $\mathrm{nm}$ & 83 & 130 & 130 \\
\hline
\end{tabular}

Apesar do bom comportamento de filmes depositados por descarga luminescente usando $60 \mathrm{~Hz}$ quando comparados com os obtidos usando RF, existem 
diferenças entre os dois tipos de filmes. Nós especulamos que tais diferenças são causadas por um bombardeamento periódico de íons de baixa energia sobre a superficie dos filmes quando a frequência do campo elétrico é de $60 \mathrm{~Hz}$. Os íons são praticamente imóveis em descargas a frequências acima de $1 \mathrm{MHz}$, mas o bombardeamento pode ocorrer a baixas frequências. Em nosso reator nós estamos usando a geometria de triodo, similar àquela usada nos sistemas de deposição por descarga luminescente a corrente contínua, projetada exatamente para prevenir o bombardeamento de íons sobre a amostra; contudo, em filmes depositados a $60 \mathrm{~Hz}$ a voltagem muda de sinal duas vezes por ciclo, e é próxima de zero para uma porção considerável do ciclo; a $10 \mathrm{~V}$, por exemplo, um íon $\mathrm{H}^{+}$é acelerado ao longo da distância típica entre as grades durante um tempo da ordem de $1 \mu$ s, e este tempo decresce com a tensão na forma $V^{1 / 2}$. Consequentemente, para uma tensão aplicada de $450 \mathrm{~V}$ em nossos filmes depositados a $60 \mathrm{~Hz}$, alguns íons de baixa energia alcançarão o substrato quando a tensão for baixa, causando deposição e decapagem periódicos na superficie do $a-\mathrm{Si}: \mathrm{H}$ em crescimento, similar àquele descrito por Tsuo et al ${ }^{5}$. Dado que o bombardeamento pelos ions fornece energia para o transporte de massa exigida para prevenir a formação de defeitos de coordenação e de microestrutura, isto pode explicar a baixa temperatura do substrato (menor do que na deposição a RF) que otimiza os filmes de $a-\mathrm{Si}: \mathrm{H}$ depositados por descarga luminescente a $60 \mathrm{~Hz}$. 


\section{SEÇÃO 6}

\section{CONCLUSÕES E SUGESTÕES PARA FUTUROS TRABALHOS}

A caracterização do reator e a medida das propriedades do silício amorfo hidrogenado ( $a$-Si:H) obtidas com o reator usando descarga luminescente a baixas frequências $(60 \mathrm{~Hz})$ encerra uma etapa das pesquisas que desejamos fazer, relativas à produção de filmes finos. Alcançando o sucesso na obtenção de filmes finos de $a$-Si:H de qualidade eletrônica com esta técnica alternativa de deposição como demonstrado acima um leque amplo abre-se para a realização de pesquisas com este material Mostraremos nesta Seção quais as possibilidades de pesquisa que parecem-nos mais atrativas para serem desenvolvidas pelo nosso laboratório (ou outros) com este material.

Tendo conseguido produzir filmes de $a-\mathrm{Si}: \mathrm{H}$ intrínseco de qualidade eletrônica, o passo seguinte deve ser a obtenção de materiais dopados com fosfóro ou boro, mediante a adição de fosfina ou diborana, respectivamente, à silana, na câmara de deposição. As linhas de gases já estão montadas, e os gases instalados, como pode ser visto na Seção 3 deste trabalho. Porém, dado que a fosfina e a diborana são gases muitíssimos mais perigosos do que a silana, o seu manuseio deve ser feito com atenção redobrada. Pelos testes realizados nas tubulações e conexões, parece que não existem vazamentos em toda a linha de gases, porém muito cuidado com estes gases deve ser tomado quando da sua exaustão para a atmosfera; jogá-los diretamente na atmosfera, mesmo diluindo-os com um gás não reativo (nitrogênio, por exemplo) não é uma atitude prudente. Para resolver este problema. já projetamos um sistema para decompor estes gases, de sorte que para a atmosfera seriam jogados apenas resíduos da sua queima. Este sistema funciona como um queimador dos gases, e é composto essencialmente de uma tubulação em forma de serpentina passando através de um sistema de aquecimento, capaz de elevar a sua temperatura acima de $400{ }^{\circ} \mathrm{C}$, onde estaria garantida a queima da fosfina e da diborana. Além disto, em reatores usando 
tais gases é imperativo ter um melhor controle sobre o fluxo dos gases; para isto, o ideal é a introdução em nosso reator de sistemas conhecidos como controladores de fluxo de massa para o controle do fluxo dos gases, que devido ao seu custo elevado ainda dependem de financiamento para serem comprados. Com a presença de ambos, $o$ queimador e o controlador de fluxos, o uso de fosfina e diborana poderá ser feita, e um trabalho importante será caracterizar o reator para determinar quais os parâmetros ótimos para a obtenção de filmes dopados com qualidade eletrônica.

Resultados preliminares já foram obtidos para a produção de ligas de carbeto de siliico amorfo hidrogenado $(a-\mathrm{SiC}: \mathrm{H})$ com nosso reator. A etapa atual desta pesquisa está no estudo da proporção entre os gases envolvidos (silana e metano), bem como nos parâmetros do reator, para obter ligas de boas propriedades.

Dada a nossa inserção dentro do Grupo de Óptica do Departamento de Física e Ciência dos Materiais do Instituto de Física de São Carlos, nosso maior interesse no estudo do $a-\mathrm{Si}: \mathrm{H}$ e suas ligas é investigar suas propriedades ópticas. Assim, estamos direcionando nossa linha de pesquisa no estudo de propriedades ópticas destes materiais. Uma área pouco investigada tem sido a de propriedades ópticas não-lineares de materiais amorfos. Nosso intuito será, então, o de investigar a interação de campos eletromagnéticos bastante intensos com estruturas amorfas semicondutoras. Por ora os resultados preliminares realizados não permitiram observações conclusivas, já que com o aparato experimental disponível em nossas mãos não foi possível separar efeitos térmicos e ópticos. Por outro lado, um dos componentes do nosso Grupo tem a previsão de construir um sistema laser em anel para que seja possível separar o efeito óptico, e assim conseguir realizar medidas do índice de refração não-linear para as nossas amostras.

Um outro assunto interessante dentro da interação de ondas eletromagnéticas com semicondutores amorfos é o da recristalização induzida por luz. Muito já foi feito neste sentido com $a$-Si:H obtido de forma tradicional. Nossa tentativa agora será a de observar se ocorrem diferenças quando tratamos com $a-\mathrm{Si}: \mathrm{H}$ obtido por descarga luminescente a $60 \mathrm{~Hz}$, já que, embora a estrutura de ambos os materiais sejam muito 
próximas, elas não são as mesmas. Dentro deste quadro, duas possibilidades não excludentes apresentam-se:

i) observar o efeito de um laser contínuo ( $c$ laser), do tipo do laser de Argônio;

ii) observar o efeito de um laser pulsado. do tipo de um laser de Nd:YAG.

Resultados preliminares feitos com este último tipo de laser indicam uma ligeira alteração no comportamento microscópico da recristalização em filmes obtidos a 60 $\mathrm{Hz}$ quando comparados com filmes a RF; pórem estes resultados precisam ser confirmados com um estudo mais sistemático deste comportamento.

Por fim, é nosso desejo também investigar o efeito da radiação eletromagnética de alta energia (Raios-X) sobre filmes de $a$-Si:H e suas ligas. Nosso objetivo é procurar por algum comportamento semelhante ao Efeito Staebler-Wronski nestes materiais. Observações preliminares indicam que ao menos a fotocondutividade destes filmes sofre um decréscimo quando eles são expostos àquele tipo de radiação.

Para finalizar este trabalho, acreditamos que o $a$-Si:H já seja um material cujas propriedades sejam bastante conhecidas, o que permite que ele apresente já nos dias de hoje um grande número de aplicações tecnológicas importantes. Material de custo de obtenção relativamente barato quando comparado com o seu similar cristalino, o $a$ $\mathrm{Si}: \mathrm{H}$ tem tido o seu uso disseminado quando grandes áreas são necessárias, como é o caso de células solares. Uma limitação no seu uso é a degradação que ocorre quando ele é iluminado, o chamado Efeito Staebler-Wronski. Procurar por processos de obtenção deste material que minimizem este tipo de efeito foi o que motivou-nos ao longo deste trabalho. Acreditamos que parte dos nossos objetivos foram conquistados: se por um lado a técnica de obtenção de filmes de $a$-Si:H empregada por nós revelouse uma alternativa interessante (filmes de qualidade inferiores àqueles obtidos de forma convencional, porém ainda assim com propriedades eletrônicas que permitam usá-los em dispositivos), por outro este trabalho permitiu a formação de um laboratório de caracterização de semicondutores amorfos, onde propriedades elétricas e ópticas 
possam ser medidas e conclusões serem tiradas. Acreditamos que aí reside o valor deste trabalho. 


\section{REFERÊNCIAS BIBLIOGRÁFICAS}

1. STERLING, H.F. and SWANN, R.C.G., "Chemical Vapour Deposition Promoted by R.F. Discharge", Solid State Electronics, 8, 653-654, 1965.

2. CHITTICK, R.C., ALEXANDER, J.H. and STERLING, H.F., "The Preparation and Properties of Amorphous Silicon", Joumal of Electrochemical Society: Solid State Science, 116, 77-81, 1969.

3. SPEAR, W.E. and LE COMBER, P.G., "Electronic Properties of Substitutionally Doped Amorphous Si and Ge", Phylosophical Magazine, 33, 935-949, 1976.

4. CARLSON, D.E. and WRONSKI, C.R., "Amorphous Silicon Solar Cells", Applied Physics Letters, 28, 671-673, 1976.

5. STAEBLER, D.L. and WRONSKI, C.R., "Optically Induced Conductivity Changes in DischargeProduced Hydrogenated Amorphous Silicon", Journal of Applied Physics, 51, 3262-3268, 1980.

6. STREET, R.A., KAKALIOS, J., TSAI, C.C. and HAYES, T.M., "Thermal-Equilibrium Process in Amorphous Silicon", Physical Review B, 35, 1316-1333, 1987.

7. STUtZMANN, M., BIEGelSEN, D.K. and STREeT, R.A., "Detailed Investigation of Doping in Hydrogenated Amorphous Silicon and Germanium", Physical Review B, 35, 5666-5701, 1987

8. CASTILHO, J.H., CHAMBOULEYRON, I. MARQUES, F.C., RETTORI, C. and ALVAREZ, F., " Electrical Conductivity of Amorphous Silicon Doped with Rare-Earth Elements", Physical Review B, 43, 8946-, 1991.

9. TSUO, Y.S. and LUFT, W., "Alternative Deposition Process for Hydrogenated Amorphous Silicon and Related Alloys", Applied Physics Communications, 10, 71-141, 1990.

10. ROBERTSON, R. and GALLAGHER, A., "Mono- and Disilicon Radicals in Silane and SilaneArgon DC Discharges", Journal of Applied Physics, 59, 3402-3411, 1986.

11. JANSEN, F., MORT, J. and MORGAN, M., "Nature and Distribution of Radicals in RF and DC Silane Discharges: Effects on Deposition Rate and Physical Properties of a-Si:H", Canadian Joumal of Chemistry, 63, 217-220, 1985.

12. KAMPAS, F.J., "Chemical Reactions in Plasma Deposition", Semiconductors and Semimetals, 21 - Part A - Preparation and Structure, 1984.

13. GALLAGHER, A., "Surface Reactions in Silane Discharges", The Physics of lonized Gases, 1987. 
14. JASINSKI, J.M. and CHU, J.O., "Absolute Rate Constants for the Reaction of Silylene with Hydrogen, Silane and Disilane", Joumal of Chemistry Physics, 88, 1678-1687, 1988.

15. KAMPAS, F.J., "Gas-Phase Free Radical Reactions in the Glow-Discharge Deposition of Hydrogenated Amorphous Silicon from Silane and Disilane", Joumal of Applied Physics, 57, 2290-2291, 1986.

16. KNIGHTS, J.C., "Plasma Deposition of a-Si:H", Material Research Society Symposium Proceedings, 38, 371-381, 1985.

17. BOHM, M., DELAHOY, A.E., ELLIS JR., F.B., ESER, E., GAU, S.C., KAMPAS, F.J. and KISS, Z., "Single Chamber Manufacturing Process for Amorphous Silicon Solar Cells", Conference Record of the $18^{\text {th }}$ IEEE Photovoltaic Specialists Conference, 888-893, 1985.

18. DICKSON, C.R., PICKENS, J. and WILCZYNSKI, "Amorphous Silicon Solar Cells Modules Fabricated with a Single-Chamber Load-Lock Deposition System", Solar Cells, 19, 179-188, 1986.

19. OHNISHI, M., NISHIWAKI, H., ENOMOTO, E., NAKASHIMA, Y., TSUDA, S., TAKAHAMA, T., TARUI, H., TANAKA, M., DOJO, $H$. and KUWANO, Y., "Preparation and Properties of Amorphous Silicon Produced by a Consecutive, Separeted Reaction Chamber Method", Joumal of Non-Crystalline Solids, 59860, 1107-1110, 1983.

20. REIMER, J.A., VAUGHAN, R.W. and KNIGHTS, J.C., "Proton-Magnetic-Ressonance Studies of Microstructure in Plasma-Deposited-Amorphous-Silicon-Hydrogen-Films", Physical Review B, 24, 3360-3370, 1981.

21. GALLAGHER, A., "Amorphous Silicon Deposition Rates in Diodo and Triode Discharges", Joumal of Applied Physics, 60, 1369-1373,1986.

22. BRODSKY, M.H., "On the Deposition of Amorphous Silicon Films from Glow Discharge Plasmas of Silane", Thin Solid Films, 40, L23-L25, 1977.

23. KNIGHTS, J.C. and LUJAN, R.A., "Microstructure of Plasma-Deposited a-Si:H Films", Applied Physics Letters, 35, 244-246, 1979.

24. POTTS, J.E., MC MILLAN, J.A. and PETERSON, E.M., "Effects of RF Power and Reactant Gas Pressure on Plasma Deposited a-Si:H", Joumal of Applied Physics, 52, 6665-6667, 1981. 
25. TURNER, D.P., THOMAS, I.P., ALLISON, J., THOMPSON, M.J., RHODES, A.J., AUSTIN, I.G. and SEARLE, T.M., "The Growth and Properties of Bias Sputtered a-Si:H", American Insitute of Physics Conference Proceedings, 73, 47-51, 1983.

26. DREVILLON, B.J., PERRIN, J., SIEFERT, J.M., HUC, J., LLORET, A., de ROSNY, G. and SCHMITT, J.P.M., "Growth of Hydrogenated Amorphous Silicon due to Controlled Ion Bombardment from a Pure Silane Plasma", Applied Physics Letters, 42, 801-803, 1983.

27. BHAT, P.K., RHODES, A.J., SEARLE, T.M., AUSTIN, I.G., and ALLISON, J., "The $0.9 \mathrm{eV}$ Defect Luminescence Band in Sputtered and Forms of Plasma-Deposited a-Si:H", Phylosofical Magazine B. 47, L99-L105, 1983.

28. SHIMADA, T., NAKAMURA, N., MATSUBARA, S., ITOH, H., MURAMATSU, S. and MIGITAKA, M., "High-Rate Deposition of a-Si:H Films from Monosilane by Hot Wall Type Simetric-Plasma CVD Reactor", Proceedings of 1 1 st Intemational Photovoltaic Science and Engineering Conference, 445-448, 1984.

29. AOZASA, M., PYON, R.G. and ANDO, K., "Bias Effects on Preparation of Amorphous Silicon in a Triode Glow Discharge", Thin Solid Films, 136, 263-274, 1986.

30. KNIGHTS, J.C., "Characterization of Plasma-Deposited Amorphous Si:H Thin Films", Japanese Joumal of Applied Physics, 18, Supplement 18-1, 101-108, 1979.

31. HOTTA, S., TAWADA, Y., OKAMOTO, H. and hamakAWA, Y., "Effects of the Substrate Potential on the Incorporation Manner of Hydrogen and Impurity in a-Si:H Films", Jomal de Physique, Colloquium C4, Suplement 10, 42, 631-634, 1981.

32. HOTTA, S., NISHIMOTO, N., TAWADA, Y., OKAMOTO, H. and HAMAKAWA, Y., "Optimization of GD a-Si:H Film Property for Photovoltaic Device by Means of the Cross Field Plasma Deposition Technique", Japanese Joumal of Applied Physics, 21, Supplement 21-1, 289-295, 1982.

33. Alvarez, F., ChAMbOUleyron, I., GobBi, A., MENDONÇA, C. and CASTRO, P.L., "On the Influence of an External DC Substrate Bias on Boron and Phosphorous Doping Efficiences in aSi: $\mathrm{H}^{\prime \prime}$, Joumal of Non-Crystalline Solids, 77878, 527-530, 1985.

34. TANIGUCHI, M., HIROSE, M., HAMASAKI, T. and OSAKA, Y., "Novel Effects of Magnetic Field on the Silane Glow Discharge", Applied Physics Letters, 37, 787-788, 1980.

IFSC - SERVICO DE BIBLIOTECA E IAFCFUAOAO 
35. OHNISHI, M., UCHIHASHI, K., NISHIWAKI, H., SHIBUYA, H., TANAKA, M., NINOMIYA, K., NISHIKUNI, M., NAKAMURA, N., TSUDA, S., NAKANO, S. and KUWANO, Y., "High-Quality a-Si Films Prepared at High Deposition Rate by Controlled Plasma Magnetron (CPM) Method", Technical Digest of the Intemational Photovoltaic Specialists Conference-3, 25-28, 1987.

36. HAMASAKI, T., UEDA, M., ChAYAHARA, A., HIROSE, M. and OSAKA, Y., "High-Rate Deposition of Amorphous Hydrogenated Silicon from a SiH 4 Plasma", Applied Physics Letters, 44, 600-602, 1984.

37. CARLSON, D.E., CATALANO, A., D'AiELlo, R.V., DICKSON, C.R. and OSWALD, R.S., "Research on High-Efficiency, Single Junction, Monolithic, Thin-Film a-Si Solar Cells", STR-2112813-SERI(atual NREL)-Golden-CO, 1985.

38. TSAI, C.C., STUTZMANN, M. and JACKSON, W.B., "The Staebler-Wronski Effect in Undoped aSi:H: its Intrinsic Nature and the Influence of Impurities", American Insitute of Physics Proceedings Conference, 120, 242-249, 1984.

39. MATSUSHITA, T., KOMORI, K., KONAGAI, M. and TAKAHASHI, K., "High Permormance Hydrogenated Amorphous Si Solar Cells with Graded Boron-Doped Intrinsec Layers Prepared from Disilane at High Deposition Rates", Applied Physics Letters, 44, 1092-1094, 1984.

40. ROSS, R.C. and JAKLIK, J., "Plasma Polymerization and Deposition of Amorphous Hydrogenated Silicon from RF and DC Silane Plasmas", Joumal of Applied Physics, 55, 1984.

41. KUMEDA, M., KOMATSU, H., SHIMIZU, T., FUKUDA, N. and KITAGAWA, N., "NMR and Electron Spin Resonance Studies on a-Si:H Prepared by Glow Discharge Decomposition of $\mathrm{Si}_{2} \mathrm{H}_{6}$ ", Japanese Joumal of Applied Physics, 24, L495-L497, 1985.

42. MATSUdA, A., KAGA, T., TANAKA, H., MALHOTRA, L. and TANAKA, K., "Glow Discharge Deposition of a-Si:H from Pure $\mathrm{Si}_{2} \mathrm{H}_{6}$ and Pure $\mathrm{SiH}_{4}{ }^{n}$, Japanese Journal of Applied Physics, 22. L115-117, 1983.

43. SICHANUGRIST, P., SUZUKI, H., KONAGAI, M. and TAKAHASHI, K., "High Rate Preparation of Amorphous-Silicon Solar Cells with Monosilane", Japanese Joumal of Applied Physics, 25, 440-443, 1986.

44. TSUO, Y.S., SMITH, E.B. and DEB, S.K., "Ion Beam Hydrogenation of Amorphous Silicon", Applied Physics Letters, 51, 1436-1438, 1987. 
45. TANAKA, K., NAKAGAWA, K., MATSUDA, A., MATSUMURA, M., YAMAMOTO, H., YAMASAKI, S., OKUSHI, H. and IIZIMA, S., "Optical, Electrical and Structural Properties of PlasmaDeposited Amorphous Silicon", Japanese Joumal of Applied Physics, 20, Suplement 20-1, 267$273,1981$.

46. KNIGHTS, J.C., LUCOVSKY, G. and NEMANICH, R.J., "Defects in Plasma-Deposited a-Si:H", Joumal of Non-Crystalline Solids, 32, 393-403, 1979.

47. OHNISHI, M., NISHIWAKI, N., TANAKA, M., NAKAMARA, N., TSUDA, S., NAKANO, S. and KUWANO, Y., "Preparation and Properties of a-Si Fiims Deposited with a High Deposition Rate", Proceedings of $1^{\text {st }}$ Intemational Photovoltaic Science and Engineering Conference, Kobe, Japan, 719-722, 1984.

48. NISHIKAWA, S., KAKINUMA, H., WATANABE, T. and NIHEI, K., "Influence of Deposition Conditions on Properties of Hydrogenated Amorphous Silicon Prepared by RF Glow Discharge", Japanese Joumal of Applied Physics, 24, 639-645, 1985.

49. LONGEWAY, P.A., "Plasma Kinetics", Semiconductors and Semimetal, 21 A, Edited by J. I. Pankove, 179-193, 1984.

50. FUKUDA, N., OGAWA, K., ABE, K., OHASHI, Y. and KOBAYASHI, S., "High Rate Deposition of a-Si:H from Disilane $\left(\mathrm{Si}_{2} \mathrm{H}_{8}\right)$ ", !st Intermational Photovoltaic Science and Engineering Conference, 107-110, 1984.

51. Ueda, M., Chayahara, A., hamasaki, T., hiRose, M. and OSAKA, Y.,"A New Mode of Plasma Deposition in a Cilindrical Drum Type Reactor", Extended Abstracts of $16^{\text {th }}$ Conference on Solid State Device and Materials, 543-546, 1984.

52. SHIMIZU, T., NAKAZAWA, K., KUMEDA, M. and UEDA, S., "Incorporation Scheme of Reducing Defects in a-Si Studied by NMR and ESR", Physica, 117B \& 118B, 926-928, 1983.

53. SOULE, D.E., REEDEY, G.T.., PETERSON, E.M. and MCMILLAN, J.A., "Relation Between Silicon-Hydrogen Complexes and Microvoids in Amorphous Silicon Films from IR Absorption", American Institute of Physics Conference Proceeding, 73, 89-94, 1981.

54. WEITZEL, I., PRIMIG, R. and KEMPTER, K., "Preparation of Glow Discharge Amorphous Silicon for Passivation Layers", Thin Solid Films, 75, 143-150, 1981. 
55. PATEL, R.I., SHIRCK, J., OLSEN, D.L., TRAN, N.T. and EPSTEIN, K.A., "High Deposition Rate Studies of Hydrogenated Amorphous Silicon", Conference Record of the 18 th IEEE Photovoltaic Specialists Conference, 1985.

56. KNIGHTS, J.C., LUJAN, R.A., ROSENBLUM, M.P., STREET, R.A., BIELGENSEN, D.K. and REIMER, J.A., "Effects of Inert Gas Dilution of Silane Plasma-Deposited a-Si:H Films", Applied Physics Letters, 38, 331-333, 1981.

57. SICHANUGRIST, P., KONOGAI, M. and TAKAHASHI, K., "High Performance a-Si:H Solar Cells Prepared from $\mathrm{SiH}_{4}$ at High Deposition Rates", Proceeding of 1 Intermational Photovoltaic Science and Engineering Conference, 187-190, 1984.

58. HIROSE, M., HAMASAKI, T., MISHIMA, Y. KURATA, H. and OSAKA, Y., Tetrahedrally Bonded Amorphous Semiconductors, 10, 1981.

59. SHING. Y.H., PERRY, J.W., COULTER, D.R. and RADHAKRISHNAN, G., "Amorphous Silicon Deposition Diagnostics using Coherent Anti-Stokes Raman Spectroscopy", Materials Research Society Symposium Proceeding, 95, 237-242, 1987.

60. TANIGUCHI, M., "Novel Effects of Magnetic Field on the Silane Glow Discharge", Applied Physics Letters, 37, 787-788, 1980.

61. SUGAI, H., TOYODA, H., YOSHIDA, A. and OKUDA, T., "Ion and Radical Contribuitions to Hydrogenated Amorphous Silicon Film Formation in a DC Toroidal Discharge", Applied Physics Letters, 46, 1048-1050, 1985.

62. OHNISHI, M., UCHIHASHI, K., NISHIWAKI, H., SHIBUYA, H., TANAKA, M., NINOMIYA, K., NISHIKUNI, M., NAKAMURA, N., TSUDA, S., NAKANO, S. and KUWANO, Y., "High-Quality a-Si Films Prepared at High Deposition Rate by Controlled Plasma Magnetron (CPM) Method", Technical Digest of Third Intenational Photo-Voltaic Science and Engineering Conference, 695698, 1987.

63. CHAPMAN, B., "Glow Discharge Process", Editado por John Wiley \& Sons, 1980.

64. CURTINS, H., FAVRE, M., WYRSCH, N., BRECHET, M., PRASAD, K. and SHAH, A.V., "HighRate Deposition of Hydrogenated Amorphous Silicon by the VHF-GD Method", Conference Record of the 19 IEEE Photovottaic Specialists Conference, 695-698, 1987. 
65. KATO, S. and AOKI,T. "High-Rate Deposition of a-SI:H Using Electron Cyclotron Resonance Plasma", Joumal of Non-Crystalline Solids, 77878, 813-816, 1985.

66. URBACH, F., "The Long-Wavelenght Edge of Photographic Sensitivity and of the Electronic Absorption of Solids", Physical Review, 92, 1324, 1953.

67. ADLER, D., "Origin of the Photo-Induced Changes in Hydrogenated Amorphous Silicon", Solar Cells, 9, 133-148, 1983.

68. FRITSCHE, H., "Characterization of Glow Discharge Deposited a-Si:H", Solar Energy Materials, 3, 447-501, 1980.

69. MOTT, N., "Conduction in Non-Crystalline Systems IV. Anderson Localization in a Disordered Lattice", Philosophical Magazine, 22, 7-29, 1970.

70. MOTT, N. and DAVIES, R., "Electronic Process in Non-Crystalline Materials", pg 32, 1979.

71. NAGELS, P., "Electronic Transport in Amorphous Semiconductors", Topics in Applied Physics, 36, 113-158, 1979.

72. ROSE, A., "Concepts in Photoconductivity and Allied Ploblems", 1963.

73. CRANDALL, R.S., "Modeling of Thin Film Solar Cells: Uniform Field Aproximation", Joumal of Applied Physics, 54, 7176-7186, 1983.

74. DRESNER, D.J., SZOSTAK, D.J. and GOLDSTEIN, B., "Diffusion Lenght of Holes in a-Si:H by the Surface Photovoltage Method", Applied Physics Letters, 38, 998-999, 1981.

75. GOLDSTEIN, B., DRESNER, J. and SZOSTAK, D.J., "The Diffusion of Holes in Undoped Amorphous Si:H", Philosophical Magazine B, 46, 63-70, 1982.

76. KOMURO, S., AOYAGI, Y., SEgaWA, Y., NAMBA, S., MASUYAMA, A., OKAMOTO, H. and HAMAKAWA, Y., "Picosecond Carrier Dynamics in Optically illuminated Glow Discharge Hydrogenated Amorphous Silicon", Applied Physics Letters, 42, 79-81, 1983.

77. HATTORI, K., MORI, T., OKAMOTO, H. and HAMAKAWA, Y., "Carrier Transport Property in the Amorphous Silicon/Amorphous Silicon Carbide Multilayer studied by the Transient Grating Technique", Applied Physics Letters, 51, 1259-1261, 1987

78. RITTER, D., WEISER, K. and ZELDOV, E., "Steady State Photocarrier Grating Technique for Diffusion-Lenght Measurements in Semiconductors: Theory and Experimental Results for Amorphous Silicon and Semi-Insulating GaAs", Joumal of Applied Physics, 62, 4563-4570, 1987. 
79. HATTORI, K., OKAMOTO, H. and HAMAKAWA, Y., "Theory of the Steady-State-PhotocarrierGrating Technique for obtaining Accurate Diffusion-Lenght Measurements in Amorphous Silicon ", Physical Review B, 45, 1126-1138, 1991.

80. BALBERG, I.,"The Two Carriers Mobility-Lifetime Products and their Light Intensity Dependencies in Hidrogenated Amorphous Silicon", Joumal of Applied Physics, 75, 914-923, 1994.

81. BALBERG, I. and WEISZ, S.Z., "Accurate Determination of the Two Carriers Steady-State Mobility-Lifetime Products in Hydrogenated Amorphous Silicon", Joumal of Applied Physics, 70, 2204-2207, 1991.

82. RITTER, D. and WEISER, K., "Ambipolar Drift-Lenght in Amorphous Hydrogenated Silicon using Steady-State Photocarrier Grating Technique", Physical Review B, 34, 9031-9033, 1986.

83. RITTER, D., ZELDOV, E. and WEISER, K., "Ambipolar Transport in Amorphous Semiconductors in the Lifetime and Relaxation Time Regimes investigated by the Steady State Photocarrier Grating Technique", Physical Review B, 38, 8296-8304, 1988.

84. SMITH, R.A., "Semiconductors", 172, 1978.

85. TAUC, J., GRIGOROVICI, R. and VANCU, A., "Optical Properties and Electronic Structure of Amorphous Germanium", Physica Status Solidi B, 15, 627-637, 1966.

86. SWANEPOEL, R., "Determination of the Thickness and Optical Constants of Amorphous Silicon", Joumal of Physics E: Scientific Instruments, 16, 1214-1222, 1983.

87. MOTT, N. F., "States in the Gap in Non-Crystalline Semiconductors", Joumal of Physics C: Solid State Physics, 13, 5433-5471, 1980.

88. YAMASAKI, S., OKUSHI, H., MATSUDA, A., OHEDA, H and TANAKA, K., "Determination of the Optical Constants of Thin Films using Photoacoustic Spectroscopy", Japanese Joumal of Applied Physics, 20, L665-L668, 1981.

89. JACKSON, W. and AMER, N.M., "Direct Measurement of Gap-State Absorption in Hydrogenated Amorphous Silicon by Photothermal Deflection Spectroscopy", Physical Review B, 25, 5559$5562,1982$.

90. VANECEK, M., KOCKA, J., STUCHLIK, J. and TRISKA, A., "Direct Measurement of the Gap States and Band Tail Absorption by Constant Photocurrent Method in Amorphous Silicon", Solid State Communication, 39, 1199-1202, 1981. 
91. MODDEL, G., ANDERSON, D.A and PAUL, W., "Derivation of the Low-Energy OpticalAbsorption Spectra of a-Si:H from Photoconductivity", Physical Review B, 22, 1918-1925, 1980.

92. DEXTER, D.L., "Absorption of Light by Atoms in Solids", Physical Review, 101, 48-55, 1956.

93. BRODSKY, M.H., CARDONA, M. and CUOMO, J.J., "Infrared and Raman Spectra of the SiliconHydrogen Bonds in Amorphous Silicon prepared by Glow Discharge and Sputtering", Physical Review B, 16, 3556-3571, 1977.

94. FREEMAN, E.C. and PAUL, W., "Infrared Vibrational Spectra of RF-Sputtered Hydrogenated Amorphous Silicon", Physical Review B, 18, 4288-4300, 1978.

95. FREEMAN, E.C. and PAUL, W., "Optical Constants of RF-Sputtered Hydrogenated Amorphous Si", Physical Review B, 20, 716-728, 1979.

96. LUCOVSKY, G., YANG, J., CHAO, S.S., TYLER, J.E. and CZUBATYJ, W., "Oxygen-Bonding Enviroments in Glow-Discharge deposited Amorphous Silicon-Hydrogen Alloy Films", Physical Review B, 28, 3225-3233, 1983.

97. CONDE, J.P., CHAN, K.K., BLUM, J.M. and ARIENZO, M., "The Effect of the Flow of Silane on the Properties of a-Si:H deposited by Concentric-Electrode Radio Frequency Glow Discharge", Joumal of Applied Physics, 71, 3990-3996, 1992.

98. LUCOVSKY, G., YANG, J., CHAO, S.S., TYLER, J.E. and CZUBATYJ, W., "Nitrogen Enviroments in Glow-Discharge-deposited a-Si:H films", Physical Review B, 28, 3234-3240, 1983. 99.TOCHITANI, G., SHIMOZUMA. M. and TAGASHIRA, H., "Properties of Hydrogenated Amorphous Silicon prepared by Low-Frequency $(50 \mathrm{~Hz})$ Plasma-Enhanced Chemical-Vapour Deposition", Joumal of Applied Physics, 72, 234-238, 1992.

100.SHANKS, H., FANG, C.J., LEY, L., CARDONA, M., DEMOND, F.J. and KALBITZER, S. "Infrared Spectrum and Structure of Hydrogenated Amorphous Silicon", Physica Status Solidi B, 100, 43-56, 1980.

101.TSUO, S., WEIL, R., ASHER, S., NELSON, A., XU, Y. and TSU, R., "'", Proceedings of the 19 IEEE Photovoltaic Specialists Conference, 705-707, 1987. 


\section{APÊNDICE 1}

O trabalho apresentado nesta Tese de Doutorado resultou em uma publicação em revista internacional com árbitro (Applied Physics Letters) e uma outra em revista nacional também com árbitro (Revista Brasileira de Física Aplicada e Instrumentação). Além disto, o referido trabalho permitiu a nossa participação em Congressos nacionais e internacionais. Neste Apêndice apresentamos um resumo destas atividades.

IFSC - SERVICOO DE BIBLIOTECA E INFORVACÃOO 


\title{
Hydrogenated amorphous silicon films by $60 \mathrm{~Hz}$ glow-discharge deposition
}

\author{
J. F. Fragalli, L. Misoguti, A. N. Nakagaito, V. Grivickas, ${ }^{a)}$ and V. S. Bagnato \\ instituto de Física e Química de Säo Carlos-USP, Caixa Postal 369, 13560-970 São Carlos SP, Brazil
}

H. M. Branz

National Renewable Energy Laboratory, Golden, Colorado 80401

(Received 28 September 1992; accepted for publication 11 March 1993)

We deposit hydrogenated amorphous silicon (a-Si:H) in a low-frequency $(60 \mathrm{~Hz}$ ) glow-discharge deposition system. The films show electronic and optical properties nearly equivalent to those of films produced by the conventional radio-frequency $(13.56-\mathrm{MHz})$ glow-discharge technique. The optimal substrate temperature for the low-frequency glow-discharge technique is $150-170^{\circ} \mathrm{C}$, about $100^{\circ} \mathrm{C}$ lower than at radio frequency. We report measurements of film properties including dark conductivity, photoconductivity, ambipolar diffusion length, infrared absorption, optical band gap, and deep defect density.

\section{INTRODUCTION}

Hydrogenated amorphous silicon ( $a$-Si:H) used in commercial electronic, xerographic, and photovoltaic devices is normally deposited from a $13.56-\mathrm{MHz}$ radiofrequency glow discharge ( $\mathrm{rf}-\mathrm{GD}$ ) in silane gas. However, numerous alternative deposition techniques have been $\mathrm{ex}$ plored in the hope of reducing the deep defect density, improving the stability, increasing the deposition rate, or lowering the deposition temperature of the films.' The plasma excitation frequency, for example, has been varied from $10 \mathrm{kHz}$ to $300 \mathrm{MHz}^{2-5}$ and dc excitation of the glow discharge is also used. ${ }^{6}$ Most recently, Tochitani et al. ${ }^{7}$ reported a Si:H growth in a $50-\mathrm{Hz}$ diode reactor. They found dark conductivity, photoconductivity, and infrared absorption spectra characteristic of device-quality rf-GD. They doped the material and deposited prototype $p-i-n$ solar cells. In this communication, we describe the properties of high-quality $a$-Si:H deposited by triode low-frequency glow discharge (If-GD) from silane at $60 \mathrm{~Hz}$. We have previously given a preliminary account of our results. ${ }^{8}$ Here, we emphasize the dependence of film quality on deposition parameters and characterize the films by a wide variety of optoelectronic techniques.

To assess film quality, we measure dark conductivity $\left(\sigma_{d}\right)$, photoconductivity $\left(\sigma_{\mathrm{nh}}\right)$, transient photoconductivity, ambipolar diffusion length ( $\left.L_{d}\right)$, infrared (IR) absorption, Urbach energy $\left(E_{0}\right)$, optical band gap $\left(E_{g}\right)$, deep defect density $\left(N_{d}\right)$, and other properties. We find that our best If-GD films have optoelectronic properties nearly as good as device-quality rf-GD $a$-Si:H films. Our optimal If-GD $a-\mathrm{Si}: \mathrm{H}$ is deposited at a substrate temperature $T_{3}$ of $150-170^{\circ} \mathrm{C}$. This is $\sim 40^{\circ} \mathrm{C}$ lower than the temperature found by Tochitani et al. and about $100^{\circ} \mathrm{C}$ lower than normally used in $r f-G D$ and dc-GD deposition. Such low deposition temperatures may be an advantage when depositing device layers on heat-sensitive materials. The low deposition frequency is also an advantage. Because $50-60 \mathrm{~Hz}$ power is universally available at low cost, our technique

"On leave from Vilnius University, Lithuania. does not require the power conversion equipment used during rf-GD deposition.

\section{FILM DEPOSITION}

We prepare a-Si:H films using the deposition system shown schematically in the inset of Fig. I(a). The system consists of a stainless-steel chamber diffusion pumped to a base pressure of $10^{-6}-10^{-7}$ Torr before each deposition run. Unlike Tochitani et al., ${ }^{7}$ we use a triode configuration. The two plasma electrodes are stainless-steel screens $15 \mathrm{~cm}$ in diameter and about $2 \mathrm{~cm}$ apart. Each has an array of $5 \cdot \mathrm{mm}$-diam holes separated by about $1 \mathrm{~mm}$. To these electrodes, we apply the $60-\mathrm{Hz}$ voltage that excites the plasma. We use a transformer to set the voltage slightly above the threshold for extinguishing the plasma. Typically, the applied voltage is $450 \mathrm{~V}$ and the plasma current is $4 \mathrm{~mA}$. The substrate and both plasma electrodes are normally at dc ground. For some runs, we applied a positive dc-bias voltage to the lower electrode. Before deposition, the chamber and substrates are cleaned by a plasma of Ar gas. During deposition, electronic-grade $\mathrm{SiH}_{4}$ and $\mathrm{H}_{2}$ gases are introduced in the chamber. We experimented with both low (about $10 \mathrm{sccm}$ ) and high (about $100 \mathrm{sccm}$ ) gas flow rates. Our typical deposition rate is about $40 \AA / \mathrm{min}$. We normally measure the substrate temperature with a thermocouple attached to the heater block. Calibration experiments show that during the deposition, the actual substrate temperature slowly rises to about $20^{\circ} \mathrm{C}$ higher than this thermocouple. However, in keeping with convention in the field, we report $T$, as measured by the thermocouple attached to the heater block.

Films are simultaneously deposited on Corning giass, fused quartz, and crystalline Si to permit various characterizations. Our best films show good adhesion to all substrates and we grow films up to $1.5 \mu \mathrm{m}$. The thickness variation is about $5 \%$ across a $3-\mathrm{cm}$-long substrate. To investigate the relation between film properties and deposition conditions, we vary the partial pressure of $\mathrm{SiH}_{4}, \mathrm{H}_{2}$ dilution of the $\mathrm{SiH}_{4}$, gas-flow rate, dc-bias voltage and $T_{3}$. We grow our best films without $\mathrm{H}_{2}$ dilution or dc bias and report these results below. 

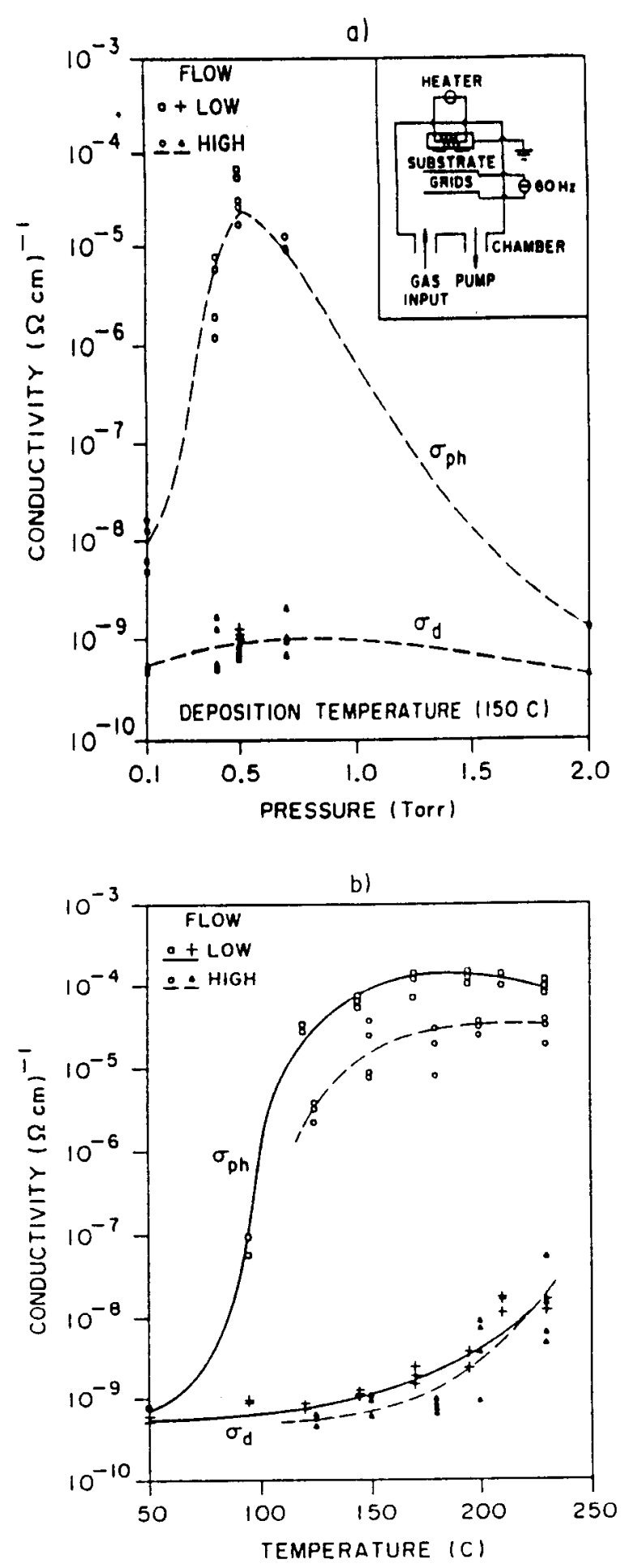

FIa. 1. Dark conductivity and photoconductivity as a function of (a) pressure at the fixed $T$, of $150^{\circ} \mathrm{C}$ and (b) substrate temperature at the fixed pressure of 0.5 Torr. The inset is a schematic diagram of the If-GD deposition system.

We obtained device-quality rf-GD films from the U.S. National Renewable Energy Laboratory and measure their properties using the same apparatuses and conditions. These rf-GD results are reported below for purpose of comparison.

\section{RESULTS AND DISCUSSION}

In Table I, we summarize measured optoelectronic properties of the $1-\mu \mathrm{m}$ If-GD $a \cdot \mathrm{Si}: \mathrm{H}$ prepared at optimal temperature and pressure. The properties we measure for device-quality rf-GD $1-\mu \mathrm{m}$ films are shown for comparison. We next discuss these results in detail.

\section{A. Photoconductlvity and dark conductivity}

Figure 1 shows photoconductivity and dark conductivity of lf-GD films. We measured photoconductivities with $2.5 \mathrm{~mW} / \mathrm{cm}^{2}$ of $0.633 \mu \mathrm{m}$ illumination from a He-Ne laser. The measurements are performed at room temperature in a coplanar electrode configuration. The data scatter shown is for repeated film depositions at nominally identical conditions.

The highest photo-to-dark conductivity ratio is obtained only for 0.5 Torr of $\mathrm{SiH}_{4}$ pressure and $T_{3}$ between 150 and $170^{\circ} \mathrm{C}$. The low flow rate yields a better ratio than the high flow rate. The other optoelectronic and structural indicators of film quality also indicated the same narrow range of optimal film deposition parameters. The photo-todark conductivity ratio of $7.5 \times 10^{4}$ of our lf-GD films is about $20 \%$ lower than in rf-GD films. The small difference may simply reflect a slightly higher optical band gap and smaller absorption in the If-GD films. The If-GD films have a room temperature value of $\sigma_{d} \approx 10^{-9}(\Omega \mathrm{cm})^{-1}$ and a dark conductivity activation energy $E_{a}$ of about $0.7 \mathrm{eV}$. With the measured $E_{g} \sim 1.72-1.8 \mathrm{eV}$ this indicates a Fermi energy near midgap. There is a rapid falloff in film quality for values of $T_{s}$ above and below the optimal range. For example, films deposited at $230^{\circ} \mathrm{C}$ have a greatly reduced $\sigma_{\mathrm{ph}} / \sigma_{d}<10^{4}$ and $E_{a} \approx 0.3 \mathrm{eV}$.

The dependence of photoconductivity on intensity in the range, $I=1-100 \mathrm{~mW} / \mathrm{cm}^{2}$ can be expressed as $\sigma_{\mathrm{ph}} \approx \Gamma^{\gamma}$ for both If-GD and rf-GD films. The value of $\gamma$ is comparable in the two types of films. This suggests that roughly the same recombination pathways determine the If-GD and rf-GD steady-state photoconductivities.

\section{B. Near-Infrared absorption}

Figure 2 shows the absorption coefficient spectra from which we derive $E_{0}$ and $N_{d}$. The spectra are taken by the constant photocurrent method (CPM). ${ }^{9} E_{0}$ is about 10 $m e V$ wider in our lf-GD films than in the rf-GD films, indicating a somewhat broader valence bandtail state distribution. We calculate the absolute magnitude of $N_{d}$ by multiplying the absorptance at $1.2 \mathrm{eV}$ by a calibration factor of $1.9 \times 10^{16} \mathrm{~cm}^{-2}$, as suggested by Smith et al. ${ }^{10} \mathrm{How}$ ever, measurements in other laboratories on nominally identical rf-GD films suggest that the absolute magnitude of $N_{d}$ we determine may be too high by a factor of 2 or 3 due to calibration error. In any case, the defect optical absorption in the best If-GD film is twice as high as in rf-GD $a$-Si:H.

\section{Diffusion length and transient photoconductivity}

We measure the ambipolar diffusion length by the steady-state photocarrier grating technique. ${ }^{11} L_{d}$ is about $130 \mathrm{~nm}$ for the high flow of If-GD films, comparable to the value in rf-GD films. It is only about $83 \mathrm{~nm}$ in low-flow If-GD films. The measurements were made in the low elec- 
TABLE I. Properties of the best If-GD films compared to a device-quality rf-GD film. The estimated measurement error is also shown.

\begin{tabular}{|c|c|c|c|c|c|}
\hline & \multicolumn{4}{|c|}{ If-GD } & \multirow[b]{2}{*}{ Error } \\
\hline & Units & High flow & Low flow & ff-GD & \\
\hline$T$ & ${ }^{\circ} \mathrm{C}$ & 170 & 170 & 240 & \pm 10 \\
\hline$\sigma_{d}$ & $(\Omega \mathrm{cm})^{-1}$ & $0.7 \times 10^{-9}$ & $1.3 \times 10^{-9}$ & $1 \times 10^{-9}$ & $20 \%$ \\
\hline$\sigma_{d}$ activation energy $E_{a}$ & $\mathrm{eV}$ & 0.7 & 0.65 & 0.71 & \pm 0.05 \\
\hline$\sigma_{\mathrm{ph}}$ & $(\Omega \mathrm{cm})^{-1}$ & $2 \times 10^{-9}$ & $1 \times 10^{-4}$ & $1 \times 10^{-4}$ & $20 \%$ \\
\hline$\sigma_{p h} / \sigma_{d}$ & $\ldots$ & $3 \times 10^{4}$ & $7.5 \times 10^{4}$ & $1 \times 10^{9}$ & $40 \%$ \\
\hline$\gamma$ from $\sigma_{\mathrm{ph}} \sim I^{\gamma}$ & $\cdots$ & 0.66 & 0.85 & 0.67 & \pm 0.05 \\
\hline$E_{n}$ & $\mathrm{meV}$ & 58 & 54.5 & 46 & \pm 4 \\
\hline$N_{d}$ from CPM & $\mathrm{cm}^{-3}$ & $2 \times 10^{16}$ & $3 \times 10^{16}$ & $1 \times 10^{16}$ & $\pm 100 \%$ \\
\hline$L_{d}$ & $\mathrm{~nm}$ & 130 & 83 & 130 & \pm 10 \\
\hline$\mu$ & rel. units" & 1 & $\cdots$ & 0.9 & $\pm 20 \%$ \\
\hline$\beta$ from $\Delta \sigma_{p h} \sim(t)^{-\beta}$ & $\ldots$ & 1.03 & $\ldots$ & 1.05 & \pm 0.05 \\
\hline$E_{t}$ & $\mathrm{eV}$ & 1.73 & 1.80 & 1.75 & \pm 0.05 \\
\hline$R$ & $\ldots$ & 0.3 & 0.25 & 0.065 & $\pm 30 \%$ \\
\hline Hydrogen content & at. $\%$ & 16 & 12 & 8 & $\pm 20 \%$ \\
\hline
\end{tabular}

Absolute values are estimated to be between 0.1 and $0.5 \mathrm{~cm}^{2} / \mathrm{Vs}$.

tric field $(<1 \mathrm{kV} / \mathrm{cm})$ and ambipolar regimes ${ }^{12}$ in which $L_{d}$ is governed by hole transport in the material.

We performed a transient photoconductivity study of our films by using 4 ns laser pulse excitation at $\lambda=0.59$ $\mu \mathrm{m}$. In this intensity range $\left(<10 \mu \mathrm{J} / \mathrm{cm}^{2}\right)$ photoconductivity is a linear function of intensity. We find the early time mobility $\mu$ at the peak of photoresponse from the expression $\mu=\Delta G h v L^{2} / e(1-R) \epsilon$. Here $\Delta G$ is the measured conductance, $R=0.3$ is the assumed reflectivity from surface, $h v$ is the photon energy, $L$ is the length of the photoconductive gap, and $\epsilon$ is the pulse energy. We find that in the high-flow If-GD sample, $\mu$ is between $0.1-0.5$ $\mathrm{cm}^{2} / \mathrm{V} \mathrm{s}$, comparable to our $\mathrm{rf}-\mathrm{GD}$ result. As an indicator

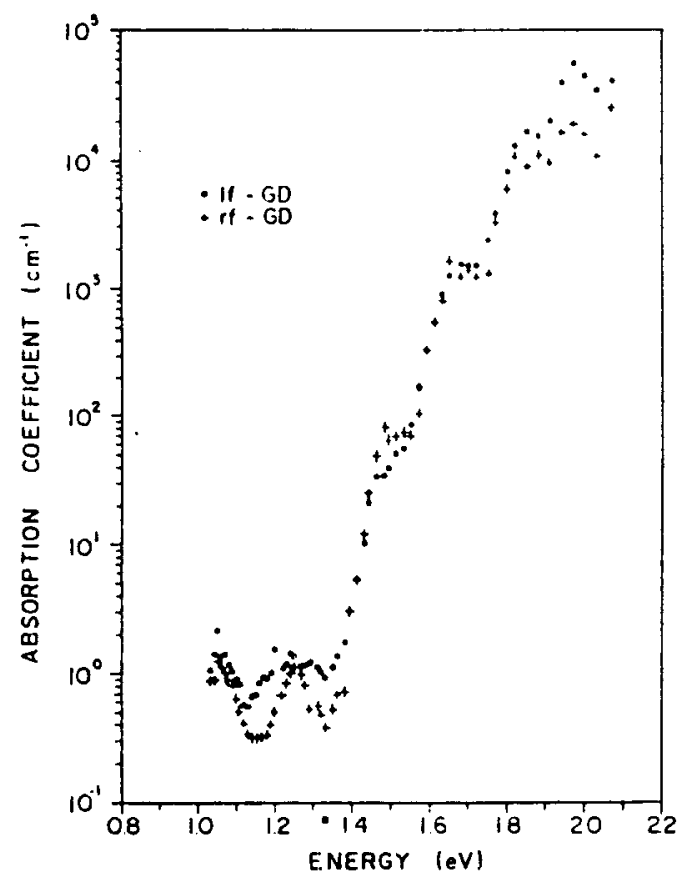

FIO. 2. Constant photocurrent method absorption coefficient spectra for high-flow If-GD and rf-GD films. of the density of shallow conduction bandtail traps, ${ }^{13}$ we measure the decay of photoconductivity from 10 to $400 \mathrm{~ns}$. It follows $\sigma_{\mathrm{ph}}=t^{-\beta}$, with $\beta \approx 1.03$. Because $\beta$ and $\mu$ are nearly identical in $\mathrm{rf}$-GD films, we suggest there are similar conduction bandtails.

\section{IR spectrum}

Figure 3 shows the IR absorption spectra of optimized low-flow and high-flow If-GD films together with the spectrum of an rf-GD film. By integrating the wagging mode peak $\left(640 \mathrm{~cm}^{-1}\right)$ and multiplying the proportionality constant $1.6 \times 10^{19} \mathrm{~cm}^{2}{ }^{15}$ we determine the hydrogen content in the films. The frequency of this $640 \mathrm{~cm}^{-1}$ vibration does not seem to depend on the preparation conditions. ${ }^{14,15}$ The $H$ content is between $13-20$ at. \% in high-flow and 10-15 at. \% in low-flow If-GD films, but is between 7 and 9 at. $\%$ in rf-GD films.

A small band-bending mode $\left(840-890 \mathrm{~cm}^{-1}\right)$ peak is observed in our If-GD, as in those of Ref. 7. It appears that isolated $\mathrm{SiH}_{2}$ groups, having a mode at $875 \mathrm{~cm}^{-1}$, are

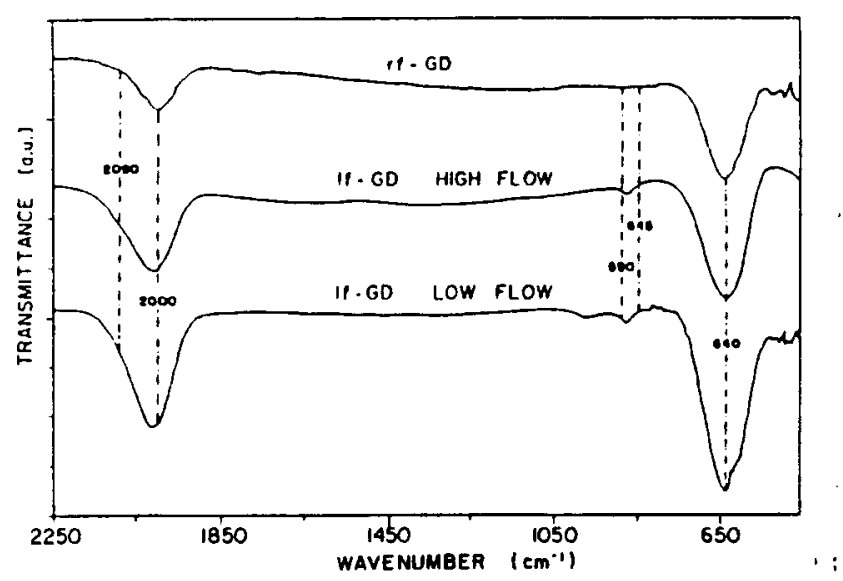

FIG. 3. IR absorption spectra of rf-GD and If-GD films. Absorption peak positions discussed in text are indicated by dot-dashed lines. 
present, rather than polymerized $\left(\mathrm{SiH}_{2}\right)_{n}$ groups with their scissors modes at 845 and $890 \mathrm{~cm}^{-1}$. ${ }^{4}$ The If.GD film also shows a small peak at $980 \mathrm{~cm}^{-1}$, which was identified as an oxygen-related hydrogen complex ${ }^{14}$ and suggest some $O$ contamination. Within the stretch-mode peak, the ratio of the $2090 \mathrm{~cm}^{-1}$ to the $2000 \mathrm{~cm}^{-1}$ peak areas, $R$, is commonly adopted as a microstructure parameter of $a-\mathrm{Si}: \mathrm{H}$. It is a factor of 4 greater in the If-GD film than in the rf-GD film, most likely due to the isolated $\mathrm{SiH}_{2}$ groups.

Finally, the ratio of the stretching to the wagging band areas in both high- and low-flow If-GD films is up to $70 \%$ larger than in the rf-GD films. There may be an unusually large oscillator strength of the $\mathrm{H}$ stretch mode in the If-GD films. Shanks et al. ${ }^{16}$ previously found that the oscillator strength decreases with increasing $\mathrm{H}$ content in ifsputtered films annealed below $260^{\circ} \mathrm{C}$. Here we observe the opposite behavior: higher $\mathrm{H}$ content in If-GD films is correlated with an increase of the oscillator strength of the stretch-mode band. It should be noted that Tochitani et al. ${ }^{7}$ grew high-quality If-GD films with a ratio of stretching to wagging $\mathrm{Si}-\mathrm{H}$ modes that appears similar to the ratio observed in rf-GD $a$-Si:H.

We speculate that the differences between If-GD deposition and previous if-GD and dc-GD deposition results are caused by a low-energy, periodic ion bombardment of the growing If-GD $a$-Si:H surface. Ions are basically immobile in discharges of frequencies above about $1 \mathrm{MHz}$, but bombardment can occur at lower frequencies. For our If-GD deposition, we are using a three-electrode geometry similar to that used in proximity dc-GD deposition to prevent ion bombardment of the sample. ${ }^{6}$ However, in If-GD, the voltage reverses twice per cycle and is near zero for a sizable portion of the cycie. At $10 \mathrm{~V}$, an $\mathrm{H}^{+}$ion is accelerated across typical electrode spacings in about $1 \mu \mathrm{s}$ and this time decreases with voltage as $V^{-1 / 2}$. Consequently, for our $60 \mathrm{~Hz}$ applied voltage of $450 \mathrm{~V}$, some lower-energy ions will reach the substrate while the applied voltage is low. This may cause a periodic etching and deposition at the $a$-Si:H surface similar to that investigated by Tsuo et al. ${ }^{17}$ Because the ion bombardment supplies energy for the mass transport required to prevent formation of coordination defects and microstructure, it may explain the low gubstrate temperature that optimizes If-GD of $a-\mathrm{Si}: \mathrm{H}$

\section{CONCLUSIONS}

.. To summarize, we deposited high-quality $a$-Si:H by a $60-\mathrm{Hz}$ glow discharge from $\mathrm{SiH}_{4}$ gas. The lf-GD films have optoelectronic properties nearly as good as those of device. quality rf-GD $a$-Si:H. Further optimization of If-GD dep. osition parameters should improve the properties still fur. ther by control of ion bombardment.

The present film quality is sufficient to enable $a \cdot \mathrm{Si}: \mathrm{H}$ deposition, research and device fabrication without the use of frequency conversion equipment. The reduced substrate temperature at which the best If-GD films are deposited presents opportunities to use $a$-Si:H with temperaturesensitive materials and in novel device structures.

\section{ACKNOWLEDGMENTS}

The authors thank R. S. Crandall of the National Renewable Energy Laboratory for supplying of-GD a-Si:H samples, J. G. Ferreira for assistance with optical absorption measurements, and Y. S. Tsuo for helpful discussions. V. G. acknowledges CNPq/RHAE for a research fellowship at IFQSC/USP.

'For a review, see Y. S. Tsuo and W. Luft, Appl. Phys. Commun. 10, 71 (1990).

${ }^{2}$ H. Fujita, H. Handa, M. Nagano, and H. Matsuo, Jpn. J. Appl. Phys. 26. $1112(1987)$

${ }^{3}$ F. Boulitrop, N. Proust. J. Magarino, E. Criton, J. F. Peray, and $M$ Dupre, J. Appl. Phys. 58, 3494 (1985)

'A. Matsuda, T. Kaga, H. Tanaka, and K. Tanaka, Jpn. J. Appl. Phys. 23, L567 (1984).

'H. Curtis. N. Wyrsch, and A. Shah, Electron. Lett. 23, 228 (1987).

'D. E. Carlson, C. W. Magee, and J. H. Thomas III, Solar Cells 1, 371 (1980).

G. Tochitani, M. Shimozuma, and H. Tagashira, J. Appl. Phys. 72, 234 (1992)

8. F. Fragalli, L. Misoguti, A. N. Nakagaito, H. M. Branz, V. Grivic kas, and V. S. Bagnato, Proceedings of Workshop on Crystalline an Amorphous Silicon and its Alloys, CNPq-NSF, Campinas, Brazil, May, 1992, p. 11.

${ }^{9} M$. Vanevek, J. Kovka, J. Stuchlik, Z. Kozisek, O. Stika, and A. Trivka. Sol. Energy Mater. 8, 411 (1983).

${ }^{10}$ Z. E. Smith, V. Chu, K. Shepard, S. Aljishi. D. Slobodin, J. Kolodrey. S. Wagner, and T. L. Chu, Appl. Phys. Lett. 50, 1521 (1987).

"D. Ritter, E. Zeldov, and K. Weiser, Appl. Phys. Lett. 49, 79 (1986)

${ }^{12}$ D. Ritter, E. Zeldov, and K. Weiser, Phys. Rev. B 38, 8296 (1988); 1. Balberg and S. Z. Weisz, Appl. Phys. 59, 1726 (1991).

"1. Kovka, C. E. Nebel, and C. D. Abel, Philos. Mag. B 63. 221 (1991)

${ }^{14}$ G. Lucovsky, I. Yang, S. S. Chao, J. E. Tyler, and W. Czubatyj, Phy9 Rev. B 28, 3225 (1983)

is J. P. Conde, K. K. Chan, J. M. Bium, and M. Arienzo, J. Appl. Phys 71. 3990 (1992)

${ }^{10}$ H. Shanks, C. J. Fang, L. Ley, M. Cardona, F. J. Demond, and S Kalbitzer, Phys. Status Solidi B 100, 43 (1980).

S. Tsuo, R. Weil, S. Asher, A. Nelson, Y. Xu, and R. Tgu, in Proceed. ings of the 19th IEEE Photovoltaic Specialists Conference (IEEE, Ne York. 1987), p. 70 s. 


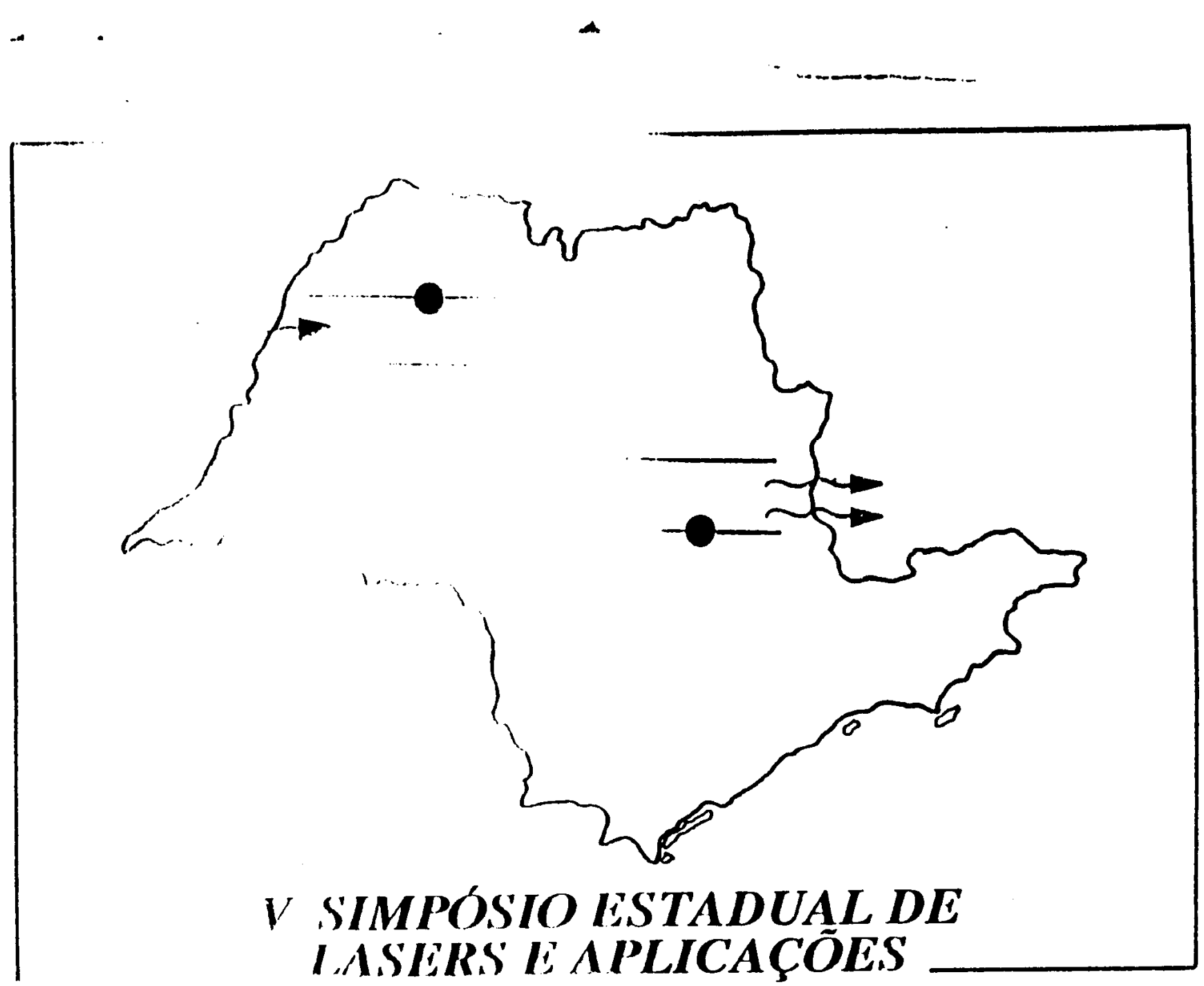

26 a 28 de Outubro de 1992

IN.TITIIY) UE PESOUISAS ENERGETICAS E NUCLEARES

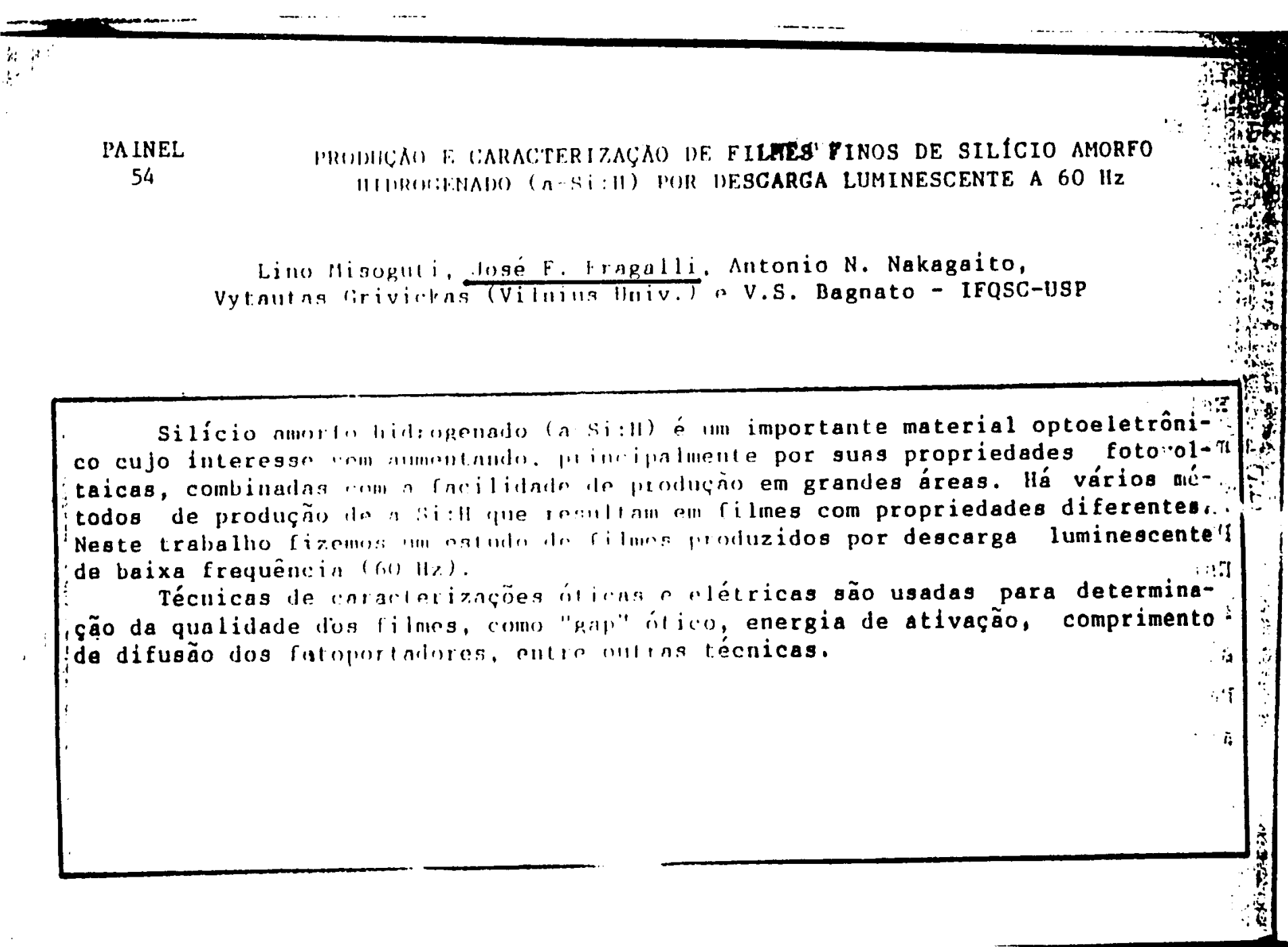




\author{
OPTICAL PROPERTIES OF AMORPHOUS \\ SILICON MEASURED USING Z-SCAN \\ TECHNIQUE \\ Kolenda, J.; Grivicicas, V \\ Vilnius Unuversaty - Vilnius

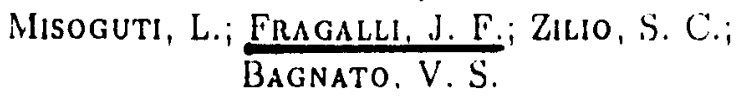 \\ IFQSC, USP - Süo Carlos
}

The investigations of amorphous hidrogenated silicon (a-bi:II) in recent time have attract many attention due to the possible applications of this layers in optical devices. The technology of a-Si:II, compared to the cristalline semiconductors, is inexpensive and there is at present time the possibility to produce the large surface area of the a-Si:Il thin films of good optical quality. The involving of this material in devices, based on nonlinear optics eflects predicts the estimation of nonlinear optical propertics of a-Si:II. In many works the time-resolved photo induced absortion (PA) and light induced grating (LIG) methods was used to estimate photoinduced changes of the optical dielectric function and carricr dynamics in amorphous silicon films. In this letter we employ z-scan technique (ZST) to investigate the third order nonlinear susceptibility of a-Si:II films produced by glow-discharge technique. 'The excitation of the samples was performed using light pulses produced by Rh6G dye laser pumped with second harmonic light pulses of activcly mode-locked Nd:YAG laser. We consider the change of absortion coefficient caused by carricrs above optical gap absortion. The influense of the overlapping effects (interference effect and thermal e:(fect) on experimental results is discussed.

\section{FOTOLUMINESCÊNCIA EM LIGAS DE CARDETO DE SILICIO AMORFO IIIDROGENADO \\ Magalitées, (E. S. de; Alvarez, F. IFGW/UNICAMP}

$\Lambda$ alta diluição de hidirogènio na mistura de inctano e silana durante o processo de deposiçào por "glow discharge" permite produzir ligas de Carbeto de Silicio amorfo hidrogenado com baixa densidade de estados $\left(10^{16} \mathrm{~cm}^{-3}\right)$ e baixa cauda de Urbach $(50-60 \mathrm{meV})$ (1). Estudamos este material através da técnica de fotoluminescéncia ( $P L)$, utilizando $\mathrm{um}$ laser de Argónio na linha $5145 \AA$ para excitação. Os resultaclos obtidos foram comparados com aqueles do Silicio aınorfo e Carbeto de Silício fabricados de modo convencional, isto é, sem diluição de hidrogenio. Observamos a $77 k$ que o comportamento da largura da banda PL, relacionada à recombinação cauda-cauda, escala com a cauda de Urbach. Esta similaridade nos leva a pensar que a largura da banda PL reflete a largura das caudas das bandas de valência e condução.

Assumindo que a dependência da eficiência PL em função da temperatura segue a relação (2)

$$
\left[\left(1 / y_{L}\right)-1\right]^{-1}=y_{0} \exp \left(-T / T_{L}\right)
$$

onde $y_{L}$ é a eficiência PL e $T_{L}$ a inclinação da cauda c banda, esta sendo em torno de $25 \mathrm{~K}$ para a-Si:II. Veril camos que o nosso material se comporta mais proxim mente ao Silício amorfo do que o convencional. Para nosso material obtivemos $T_{L} \simeq 50 \mathrm{~K}$, e para o convel cional em torno de $102 \mathrm{~K}$.

Finalmente, resultados da dependência da PL com intensidade de excitação e com a energia de excitaçã são apresentados e discutidos.

(1)Alvarez F.,Sebastiani M., Pozzili F., Fiorini P. as Evangelisti F., 1902, J. Appl. Phys., 71(1), 207.

(2)R.A.Street, "Hydrogenated amorphous silicon Cambridge University Press, 1091.

A INFLUENCIA DOS PLASMÔNS NO ESPECTRO DE LUMINESCÊNCIA DOS SEMICONDUTORES DE GAP DIRETO. Sampalo, A. J. da C.; Costa Fillo, R. N. da. Freire, V. N.

Departamento de Física da Universidade Federal do Ceal Campus do Pici - Cx. Postal 6090 Fortaleza - Ceará CEP $60 \$ 51.970$

No traballıo de Valder N.Freire sobre a influèn. la interação Coulombiana entre portadores no pectro de luminescência de semicondutores de C. direto,observou-se um pico luminescente na borda espectro ou seja na regiōo de mais alta energia.

Neste trabalho nos introduzimos um novo II amiltonia: que leva em consideração a interaçāo Elétron-Plasm.. para tentarmos verificar realmente a causa do pico! minescente citado acima.

$\Lambda \mathrm{raz}$ ao de introduzirmos os Plasmons vem do fa. de que os mesmos surgem quando existe uma forte $i$ teração Coulombiana no gás de Elétron-Buraco.E: é exatamente a situação que ocorre nos semicondut res altamente excitados, proporcionando portanto p. sivéis processos de recombinação entre os elétrons e . plasmons.

Degradaçāo da Superfície de InGaAs e Iul' Submetidas a Plasma de $\mathbf{H}_{2}$ Goвbi, A. L.; Lamas, A. C.

CPqD Telebrás, C.P. 1579, Campinas 19088-061

Plasma de hidrogênio é uma lécnica amplamente utj zada na fabricação de dispositivos optoeletrónicos cos base em semicondutores III-V para uso em telecom nicaçōes. Esta técnica é empregada na remoção de h drocarbonos, óxidos nativos, deposição de dielétric e no ataque químico de ligas semicondutoras. A e: posição direta de superfícies de InP a plasmas de U 
mesino que a temperatura ambiente, provoca perda de lissforo devido a criação de fostina contorme demonstram os resultados de EDX.

Amostras de InGaAs, parcialinente cobertas por fotoresiste, foram submetidas a plasma de $\mathrm{II}_{2}$ de baixa leusidade de potência $\left(0.28 \mathrm{~W} / \mathrm{cm}^{2}\right)$. Resultados de mapeamento da intensidade de fotoluminescencia do pico de recombinação banda-banda do InGads, indiram uma redução na intensidade do sinal detetiulo na regiào descoberta da amostra, proporcional ao tempo de exposiçio ao plasma. A variação temporal nit intensidade do sinal de fololuminescencia desta regiño, apresenta comportamento similar ao de amostras de lnLass passivadas com nitreto de silicio, demonstrando assiun a eficácia do fotoresiste como muscara. Mualise simular mostra que, a regiáo exposta ao plasma de $\mathbb{I}_{2}$, apresenta um aumento na eficiencia dos mecanismos de recombinação não-radiativa.

\author{
RESPOSTA ÓTICA NÄO LINEAR DE \\ FILMES FINOS DE $a-S i: H$ COM \\ DISCRIMINACÄO DE EFEITOS \\ ELETRÔNICOS E TÉRMICOS \\ Ribeiro, R. M.; Margulis, W. \\ Departamento de Fisica, PUC-Rio \\ LEITE, C. A. F. \\ Instituto de Fisica, UFF \\ Givedes, 1 \\ IFQSC, USP.SC
}

Com a finalidade de calcularmos a susceptibilidade elétrica de $3 a$. ordem $\left(\gamma^{(3)}\right)$ e identificar as contribuiçóes eletronica e térmica Medimos a eficiencia de autodifraçia de filmes finos de a-Si:11 em 532 nan onde a absorçĩo da luz é bastante significativa $\left(>10^{5} \mathrm{~cm}^{-1}\right)$. Resolvemos temporalmente a rede transiente criada nos tilmes por dois feixes de NA-Yili, operando een "Qswitching" e "mote-locking" utilizando como "probe" um laser CWV de IleNe de $10 \mathrm{~m} W$. Foi possivel observar a difração do feixe de lleNe para cada trem de pulsos do laser de $\mathrm{Nd}: \mathrm{YAG}$. Mostramos assim ser possivel dis. criminar as contribuiçóes cletrónica e térnica para o cálculo de $\chi^{(3)}$ a parlir da observação da formação e decaimento da rede transiente.

\section{Z-SCAN WITH TEMPORAL RESOLUTION Misoguti, L.; Fragalli, J.F.; Zilio, S. C.; \\ IFQSC, USP - Säo Carlos KOLENDA, J. \\ Vilnius University - Vilnius}

The z-scan technique (ZST) provides the possibility to investigate optical refractive and absorptive nonlinearities in the simple way. This technique enables to obtain the real and imaginary part of the third or higher orders nonlinear susceptibility. Using ZST one get the definition of the sign of the optical nonlinearity, what is not possible to determine from light induced grating (LIG) method, because LIG signal is proportional to the square of $\chi^{(3)}$. The ZST provides the possibility to overpower this and other difficulties. In this works we show a like two colours z-scan technique to investigate the magnitude and temporal behavior of the absorption coefficient and refraction index degenerated as well nondegenerated nonlinearities. This method was eInployed for experimental investigations of optical noulincarities in CdSSe microcrystals containing glasses (comercial Slıott OG550 filters). The estimated value of the real part of $\chi^{(3)}=1.910^{-8}$ esu at time overlap of pump and probe pulses. The experiemental results obtained by other groups are in range $10^{-\gamma}-10^{-12}$ esu.

\section{LASERS DE POÇØQUÂNTICO TENSIONADO EMITINDO EM $980 \mathrm{~nm}$ PARA USO EM AMPLIFICADORES ÓPTICOS À FIDRA.}

Macilado, A. M.; Bernussi, A. A.; Cogili, C. A.; MARTINS, R. $B$. CPQD-TELEBRAS

Os lasers semicondutores de potência com emissāo em $980 \mathrm{~nm}$ demonstraram ser uma excelente alternativa como fonte de bombeio altamente eficiente para os amplificadores ópticos a fibra dopada com Érbio ${ }^{a}$. Lasers com emissão neste comprimento de onda são obtidos com estruturas utilizando poços quânticos tensionados de GaAs/InGaAs. Em geral os lasers crescidos sobre substrato de GaAs possuem como camadas confinantes ligas à base de GaAlAs. Porérn, a aplicação desta liga em dispositivos de potencia apresenta caractcr'isticas indesejàveis tais conı uma menor dissipação térmica e uma maior facilidade de oxidação dos espethos, o que aumenta a probabilidade de degradação do dispositivo ${ }^{b}$. Neste trabalho apresentamos estruturas laser de potência com emissão em $980 \mathrm{~nm}$ utilizando a liga de GalnP como camadas confinantes, substituindo a liga de GaAl As. Estas estruturas foram crescidas, processadas e caracterizadas no CPqD-TELEBRAS. Mostramos que a utilização desta liga, apesar de não ser tão bem caracterizada quanto a de GaAlAs, permile a obtenção de lasers com caracteristicas eletro-ópticas. equivalentes aos lasers à base de GaAlAs, com promessas de um melhor desempenho do ponto de vista de confiabilidade. Estruturas tipo "broad area" mostraran valores de corrente limiar da ordem de $180 \mathrm{~A} / \mathrm{cm}^{2}$, eficiència quântica diferencial interna de $70 \%$, coeficiente de perdas internas de $20 \mathrm{~cm}^{-1}$ e potencias ópticas acima de $350 \mathrm{~mW} /$ face. Os primeiros resultados obtidos com as estruturas tipo "Ridge Waveguide" são também encorajadores: baixa densidade de corrente limiar $\left(320 \mathrm{~A} / \mathrm{cm}^{2}\right)$, boa eficiência quântica diferencial extcrna (65\%), potência óptica de até $90 \mathrm{~mW} /$ face e excelente razão entre as aberturas dos campos afastados 


\section{FLUTUAÇĀO DA CORRENTE ELÉTRICA EM SISTEMAS DE DALXA DIMENSIONALIDADE FORTEMENTE CORRELACIONADOS \\ LATGÉ, A.; $\Lambda$ NDA, E. $U F F$}

O ruido no transporte dos portadores de cargas em hetcroestruturas de dupla barreira unidimensionais é estudado neste trabalho usando-se o formalismo de Keldysh para calacular as funçōes de Green fora do equilíbrio. Como é bem sabido, o transporte de carga $\mathrm{em}$ heteroestruturas de baixa dimensionalidade sofre um bloqueamento (bloqueamento de Coulomb) devido a prtesença do eletron localizado no poço, o que produz uma fenomenologia muito interessante no transporte elétrico. Propomos um Hamiltoniano tipo impureza de Anderson para descrever este sistema e adotamos a aproximação da analogia de liga. A flutuaçà da corrente em funçāo da frequencia e do potencial externo aplicado a heteroestrutura, e o processo de inutticstabilidade produzido pela correlação eletrónica são analisados. Propōe-se também um experimento para o estudo dos resultados teóricos obtidos.

\section{DETERMINAÇĀO DA VELOCIDADE DE RECOMBINAÇĀO DOS PORTADORES MAJORITÁRIO EM FILMES DE a-Si:H PELA TÉCNICA DE SSPG. \\ Misoguti, L.; Fragalli, J. F; Nakagaito, A. N.; BAGNATO, V. S. \\ IFQSC, USP - São Carlos KOLENDA, J. \\ Vilnius University - Lilnius}

A lécnica conlecida como SSPG (Steady State Pliotocarricr Grating technique) foi introduzido recentemente por litter et al, permite a medida do comprimento de difusão ambipolar dos fotoportadores em fimes finos de silicio amorfo hidrogenado (a-Si:II). Esta técnica é baseada na criação em estado estacionário de uma grade de fotoportadores de pequena amplitude sobre um fundo uniforme de foloportadores. Para produção da grade de foloportadores utilizamos un laser de He-Ne sintonizável. Esta mesma técnica pode ser utilizada para determinação da velocidade de recombinação superficial em filmes de a-Si:Il com a utilização de comprimentos de ondas diferentes para produção da grade de fotoportadores. As consideraçōes teóricas e os resultados são analizados.

\section{O PROCESSO DE RECOMBINAÇĀO DOS PORTADORES FOTOGERADOS NAS LIGAS DE SILICIO E GERMÂNIO AMORFOS HIDROGENADOS \\ Graeff, C. F. de O.; Chambouleyron, I. E. UNICAMP}

\section{Brandt, S. M.; Stutzmann, M. MPI-FKF Slultgarl, Germany}

Neste traballıo apresentamos o processo de recombinação dos portadores fotogerados nas ligas de silicio e germãnio amorios lidrogenados $\left(\mathrm{a}-\mathrm{Si}_{1-x} \mathrm{Ge}_{x}: \mathrm{II}\right)$, elucidados por medidas de Spin Dependent Photoconductivity (SDPC). O estudo compreende todo o espectro de composições das ligas a-Si ${ }_{1-x} \mathrm{Ge}_{x}$ :II $(0 ; \mathrm{x} ; 1)$. As amostras foram crescidas na forma de filmes finos, com espessura tipica the $1 \mu \mathrm{m}$. $\Lambda$ análise dos formatos de linhas ( line shapes), e do valores do lator $g$ cilcontrados, indicam que o processo de recombinação dominante, para $100 \mathrm{~K}$; T ; $300 \mathrm{~K}$, é o tunelamento le elétrons da cauda da banda de condução para uma ligação não pendente (dangling bond DB ). Os resultados apontam que incorporaçäo mesmo de pequenas quantidades de germânio ( $11 \%$ ) provocam grandes mudanças no processo de recombinação, seja pela introduçõ de DBs do germânio, ou pelo alargamento da banda de condução. As mudanças provocadas pela incorporação do germànio, são responsáveis pela rápida leterior ação das propriedades opto-eletronicas nas ligas a-Si $i_{1-x} \mathrm{Ge}_{x}$ :Il com o incremento de $\mathrm{x}$.

Tempo de vida em semicondutores através de reflectáncia.

Pires, M. P.

Departamento de Fisica - PUC-Rio

WEID, J. P.; SoUzA, P. L.

CETUC - PUC-Rio

Usando um laser $\mathrm{Nd}-\mathrm{Y} \Lambda \mathrm{G}$ dobrado em frequência como feixe de bombeio e como feixe de prova um laser semicondutor gain-switched, com o comprimento de onda ressonante com o gap do material, mede-se o tempo de vida dos portadores de uma amostra semicondutora Este método utiliza o batimento dos dois feixes - em baixa frequencia para modular. também em baixa frequéncia, a refletividade na superfície da amostra, de forma a ter a informação do tempo de vida inserida na refletividade. Determina-se, então, o tempo de vida em camadas espessas de $\Lambda \mathrm{IGaAs}$ e em poços quânticos de $\lambda l_{x} \mathrm{Ga}_{1-x} \Lambda \mathrm{s} / \mathrm{Al}_{y} \mathrm{Ga}_{1-y} \mathrm{As}$ e compara-se estes resultados com resultados medidos através de outros métodos.

Uma nova abordagem para o efeito de "overshoot" de temperatura dos fonons $L O$ Rego, L. G. C.; Algarte, A. C. S. UNICAMP

Estudamos a dinâmica de portadores e fônons quentes gerados por pulsos ópticos de 1 ps no cristal de GaAs. Baseados na blindagem eletrônica da interação polar, propomos um novo modelo capaz de descrever adequadamente o fenômeno de "overshoot" de temperatura dos fônons LO. Esta nova abordagem, distinta da anterior (D.S. Kim e P. Yu, PRL 64 1990) por não levar em 


\section{"Soltness" e Segregaçāo de Impurezas em Semicondutores \\ DAL-PINO JR, A \\ Instiluto Tecnológico de seronáulica - ITA}

Nós analisamos o processo de segregação de impurezas em interfaces como uma reação quínica entre impurezas e a interface ${ }^{(1)}$. Deste ponto de vista, testamos a habilidade dos conceitos de "local softness" e "hardness" para prever os sitios mais prováveis para a acumulação de inpurezas. Investigação a nivel de primeiros principios da $\Sigma=5$ tilt[310] "grain boundary" $\mathrm{em}$ Ge é apresentada e a energia de acumulação de dopantes nessa interface é estudada. Nossos rcsultados inostram que a análise de problemas de matéria condensada pode ser enriquecida pela aplicação dos conceitos quimicos de "softness" e "hardness".

(1) A. Dal Pino Jr. et al, Journal of Chemical Physics (1993), aceito para publicação

\section{Wire Crystals GaAs and InAs Grown by MBE} on Porous Silicon

Lunyshev, D. L.; Rossi, J. (.); Ciussev, G.; BASMAJI, P?

IFQSC-USP - São Carlos - SP.

Epitaxial layers of GaAs or (InAs) on porous Si (PS) have been grown at different substrate temperatures $T_{1}=200-500^{\circ} \mathrm{C}$ by molecular beam epitaxy (MBE). The dependence of the surface morphology on the growth conditions has been investigates. The possibility to grow GaAs (or InAs) nano-scale wire crystals with lenghts of $5 \mu \mathrm{m}$ and diamcter between 75 and 100 nm has been also demonstrated. We believe that the germ formation of nano crystal begins on the output of the dislocation into the GaAs growing layer. The substrates used were $\langle 111\rangle$ oriented to ohm.cm resistivity boron-doped p-type silicon. The anodization was carried out using $25 \%$ HF solution in water, al current density of $30 \mathrm{~mA} / \mathrm{cm}^{2}$. After electrochemical preparation, porous silicon was introduced in MBE machinc and GaAs (or InAs) was grown in two steps. Our results show two possible mechanisms of growth. The first mechanism we suggest is the anomalous long diffusion length of $\mathrm{Ga}$ adatoms on the lateral surface of the growing crystals. The second mechanism, we suppose the existence of associates and microclusters of $\mathrm{Ga}$ and As atoms on the surface semiadsorbtional layer.

\section{NOVO MÉTODO PARA DETERMINAÇĀO DE PARÂMETROS ÓPTICOS DE FILMES FINOS ANISOTRÓPICOS.}

Eragalli, J. F.; Misoguti, L.; Surdotovici, G.; VITLINA, R.

IFQSC, USP - Säo Curlos

É proposto um método para a delerminação das componentes superficiais paralelas $N_{x}$ e perpendicular $N_{z}$ do indice de refração de filmes anisotrópicos sobre substratos isotrópicos. O método é baseado na medida das oscilaç oes na refletividade da luz polarizada $S$ e $P$, variando-se o ângulo de incidência. Para a polarização $S$ o padrão de interferência depende apenas da componente $N_{x}$, ao passo que para a polarização P ele depende também da componente $N z$. Variando-se o ângulo de incidência $\phi$, a diferença de caminho óptico $\gamma_{p}$ e $\gamma_{S}$ serão diferentes e dependerão do grau de anisotropia $\beta=\left(N_{z} / N_{z}\right)-1$. Para $\beta<1$ esta diferença toma a forma $\gamma_{P}-\gamma_{S}=\beta \operatorname{sen}^{2}(\phi) \gamma_{S} /\left(N_{x}^{2}-\operatorname{sen}^{2}(\phi)\right.$. Para filmes com espessuras da ordem de $2-3 \lambda$, onde $\lambda$ é 0 comprimento de onda da luz incidente, e anisotropia $\beta$ entre 0.1 e 0.2 o número de oscilações das polarizações $S$ e $P$ podem diferir por 20 a $30 \%$ quando se varia $\phi$ le 0 a $\pi / 2$. Uma estimativa deste efeito em filmes de silicio poroso sobre substratos de silicio cristalino demonstra uma excelente oportunidade para observar $\checkmark$ efeito, mesmo com medidas simples de refletividade, sem usar dados de elipsometria. O efeito se torna mais claro para casos onde $N_{x}-1<1$ que é típico em filmes de silicio poroso com porosidade suficientemente grande.

\section{COMPORTAMENTO DE NÍVEIS PROFUNDOS METAESTÁVEIS COMO CAMPO ELÉTRICO EM AMOSTRAS DE GaAs-n SUBMETIDAS A RTA \\ Pascoal, H. B.; Costa, J. A. P. DA UFRN \\ Pudensi, M. A. A. UNICAMP}

E sabido que alguns níveis profundos no arseneto de gálio e no fosfeto de indio são afetados por campos elétricos. $O$ presente trabalho foi realiza- do em amostras de arseneto de gálio dopados com silicio a uma concentra- ção de $10^{16} / \mathrm{cm}^{3}$. As amostras foram subinetidas a RTA (Rapid Ther- mal Annealing) a uma temperatura de $870^{\circ} \mathrm{C}$ durante $60 \mathrm{seg}$. com duas coberluras diferentes: dióxido de silicio e spin-on-glass dopado com estanho (SOG:Sn). Os espectros obtidos por DLTS (Deep Level Transients Spectroscopy) revelaram na amostra recozida com dióxido de silicio, a existência de quatro níveis, dos quais dois mostraram-se ser eletricamente controláveis. Na amostra recozida com spinon-glass foram observados dois níveis, sendo que apenas um mostrou-se sofrer influência do campo elétrico. Devido à rever- sibilidade desses níveis, foram sugeridos alguns modelos como sendo constitu- ídos por defeitos pontuais, defeitos complexos e impurezas rasas.

IMPLANTAÇĀO DUAL DE IONS DE BORO E CARBONO EM SILICIO. SoUzA, J. P. DE; Boudinov, H. UFRGS 
de transmissão foi observado e se mostrou dependente da tensào aplicada. Uma análise quantitaliva da energia de separação entre os niveis discretos 1-D) é feita e baseia-se na modelização do potencial perturbador por um potencial harmonico.

\section{'ASSOCIAÇÃO EM SÉRIE DE RESISTORES BALISTICOS \\ NEVES, J. M. UFMG}

Main, P.; Eaves, L.; Henini, M. Nollingham Universily - Reino Unido

Esludou-se a associação cIn série de dois contatos quânticos puntuais com scparaçào inferior ao caminho livre médio dos el'etrons. Esses resistores balisticos foram criados por "split gates" fabricados sobre una heterojunção de GaAs-AIGaAs. Duas geometrias foram consideradas: uma contendo contatos quänticos colineares e outra com contatos perpendiculares. Mediuse a resistência da associação c a resistència individual de cada contato quántico como função da tensão aplicada aos gates em difcrentes campos magnéticos. Foi confirmado que em geral as resistencias de resistores balísticos não segue a regra clássica de soma. De fato a resistência da associaçào pode ser consideravelmente menor que a soma das resistências dos conlatos quânticos. Apartir do formalismo de Landauer-Buttiker, derivou-se uma expressào geral para a resistencia da associação em termos dos coeficientes de Landauer. Esses coeficientes foram calculados apartir dos resultados experimentais e mostrou-se que sua dependencia na largura dos contalos quanticos e no campo magnético aplicado pode ser entendida classicanente.

\section{DEPENDENCIA TEMPORAL DA REDUÇĀO NA CONCENTRAÇÄO DE DOPANTES EM ESTRUTURAS MOS APOS EXPOSIÇÃO Ȧ RADIAÇÃO IONIZANTE \\ VASCONCElos, E. A. DE; JÚNior, E. F. IA S. Departanento de Fissea - lttPll}

A geração de defeitos em estruturas Metal-ÓxidoSemicondutor (MOS) temn sido objeto de intenso estudo por várias décadas. Defeitos gerados nas vizinhanças da interface $\mathrm{SiO}_{2} / \mathrm{Si}$ são os principais responsáveis por fathas em dispositivos e circuitos de tecnologias vançadas. Neste trabalho apresentamos resultados recentes da irradiação de estruturas MOS por raios- $X$ com energia de $40 \mathrm{KeV}$, que geraın defęitos na interface $\mathrm{SiO}_{2} / \mathrm{Si}$ e cuja conseqüêucia é a redução na concentração aparente de dopantes no sililio. Esta reduçào se dả em larga escala dependendo da lose de radiação e apresenta uma dinâmica temporal ao longo de muitas ordens de grandeza. Discutiremos os parámetros mais importantes que afetam a dinamica destes deleitos, entre os quais destacam-se: a dose total de irradiação, o tamanho do dispositivo, a distribuição de stress na interface $\mathrm{SiO}_{2} / \mathrm{Si}$, e a espessura do filme de óxido de silicio. Os resultados indicam que a redução na concentração de dopantes nas vizinhanças da interface $\mathrm{SiO}_{2} / \mathrm{Si}_{i}$ está associada ao enfraquecimeneto e/ou quebra de ligações químicas nas suas proximidades e com a formação de armadilhas eletricamente ativas ou não. Estas, aprisionam portadores e ocasionam uma redução da concentração de dopantes. Mostraremos que estes defeitos uma vez gerados, proliferam-se nas vizinhanças da interface $\mathrm{SiO}_{2} / \mathrm{Si}$, degradando as caracteristicas elétricas los dispositivos até sua falha total. Crescimento, Caracterização e Pro-
pricdades Ópticas (SEM) - 10/06/94

MEDIDA DO PRODUTO
MODILIDADE-TEMPO DE VIDA EM
ESTADO ESTACIONÁRIO DOS DOIS
PORTADORES NO A-Si:H USANDO A
TÉCNICA DE SSPG

Misoguti, L.; Nakagaito, A. N.; Ramos, L. R.; BagNato, Y.S.

IFQSQ, USP - Säo Carlos Fragalli, J.F.

Departamento de Física - Campus de Bauru - UNESP

A técnica de SSPG (Steady State Photocarrier Grating technique), atualmente largamente utilizado para melida de comprimento de difusão ambipolar dos portadores no silicio amorfo hidrogenado (a-Si:H) e suas ligas, no regime de altos campos elétricos permite determinar 1) valor preciso do produto mobilidade-tempo de vida ( $/ 1 T$ ) para ambos portadores. Estes dois paràmetros são cle fundamental importancia para as propriedades optoeletrónicas do material, $\mu$ contém informaçōes sobre mecanisınos de transporte, e $\tau$ mecanismo de cinética le recombinação. Portanto há um grande interesse de se conhecer o valor exato destas grandezas. Analizamos esta nova técnica de medida com os métodos tradicionais de fotocondutividade, que tem uma grande imprecisão devido a dificuldades inerentes de difícil solução, e comparamos os resultados e o regime de validade.

\section{Medidas de Fotoluminescência em Poço Quântico Assimétrico de InP-InGaAs Cardoso, A. J. C.; Morais, P. C. de \\ Departamento de Fisica Universidade de Brasilia.}

Apresentaremos medidas preliminares de fotoluminescência em poço quântico assimétrico simples em heterostruturas de InP-InGaAs, crescidas por VLE ("Va- 


\author{
ANÁLISE COMPOSICIONAL E \\ ESTRUTURAL DE AMOSTRAS \\ ENVELHECIDAS DE SILÍCIO POROSO. \\ Freire JR, F. L. \\ Departamento de Física - PUC-Rio \\ Mariotto, G.; Ziglio, F. \\ Dipartimento di Fisica, Università di Trento - Llália
}

Neste trabalho são apresentados resultados da análise superficial de amostras envelhecidas de Silicio-Poroso (SP), com diferentes graus de porosidade (65 e $85 \%$ ), com a utilização de técnicas mucleares: ERDA, RBS, Channeling e Reaçōes Nucleares. A análise estrutural é feita com micro-Ranian. Resultados de fotoluminescência também serão discutidos. $\mathrm{A}$ análise quimica indica a presença de considerável quantidade de oxigènio, carbono e hidrogènio na superfície das amostras estudadas. $\Lambda$ análise Raman revela diferentes microestruturas das camadas de SP, que emitem no visivel com eficiências muito diferentes e com máximo de fotoluminescència diversos. Uma correlação entre a análise composicional e a microestrutura permite interpretar os diferentess aspectos do espectro de emissão de luz. O "blue-shift" observado no espectro de luıninescência da aınostra con menor porosidade é explicado com o maior consumo de silício durante o processo de envelhecimento da amostra.

Effect of alloy disorder and structural defects on exciton properties in lattice-matched (100)and (311)-oriented InGaAs/GaAs quantum wells

Guimarães, F. E. G.; Lubyshev, D.; Sibrão, E. R.; Cuttra, V. A.; Basmaji, P.

Instilulo de Física e Quimica de Süo Carlos, USP

Photoluminescence (PL), photoluminescence excitation (PLE) and Raman spectroscopy are used to analyse the properties of pseudomorphic InGal-xAs/GaAs quantum well $(\mathrm{QW})$ structures. Strained $\mathrm{QW}$ 's with different thicknesses $(2 \mathrm{~nm}<\mathrm{Lz}<10 \mathrm{~nm})$ are grown by molecular beam epitaxy side by side on (100)-, (311)Aand (311)B-oriented GaAs substrates. There are significant differences in the optical properties and growth kinetic of samples having the two inequivalent (311) and the (100) surfaces. PL spectra at $17 \mathrm{~K}$ observed in this work from $3 \mathrm{~mm}$ In $0.2 \mathrm{Ga} 0.8 \mathrm{As} / \mathrm{GaAs}$ single $\mathrm{QW}$ 's show high quality QW's and extremely narrow gaussian shaped excitonic emissions with linewidth of about 0.8 $\mathrm{meV}$ for both (311)- oriented samples. However, all orientations have different dependence of the luminescence linewidth on the well width. For the (311)A sample, the observed $\mathrm{Lz}$ dependence of the linewidth is a common feature of InGaAs/GaAs QW's and is well explained in terms of an inhomogeneous broadening of the excitonic states by alloy scattering mechanisms. Indeed, according to our growth conditions used we expect very low contribution of interfacial scattering mechanism. These results show further that the alloy disorder in the InGaAs well is higher in the (100)-orientation than in the (311)A ones. In the case of the (311)B- orientation the broadening of the excitonic linewidth is limited not only by alloy disorder but also by defect-related mechanisms. Raman and PL measurements on highly strained multiple quantum well structures also reveal different strain states and different mechanisms of lattice-match accomodation in the three orientations studied here. We observe that the InGaAs layers with (311)A-orientation are more stable in termis of elastic strain accomodation than by generating misfit dislocations. According to the above findings, we state that the different alloy and defect states are originated in the different growth mechanism on the three inequivalent (311)- and (100) surfaces.

\section{ESTUDO DE DEFEITOS METAESTÁVEIS INDUZIDOS POR RAIOS-X EM FILMES DE SILICIO AMORFO HIDROGENADO Fragalli, J. F. \\ Deparlamento de Fisica - Campus de Bauru - UNESP \\ Misoguti, L.; Nakagaito, A. N.; Ramos, L. R.; Bagnato, V.S. \\ IFQSQ, USP - Säo Carlos}

Filmes de silicio amorfo hidrogenado preparados por descarga luminescente a $60 \mathrm{~Hz}$ foram submetidos a radiação eletromagnética de alta energia (Raios- $X$ na faixa de $1.5 \mathrm{keV}$ ). A radiação provoca o surgimento de defeitos metaestáveis no filme, similares àqueles provocados por luz visivel, conhecido na literatura por Efeito Staebler-Wronski. Os valores da energia de ativação da condutividade aumentam após a irradiação, indicando um abaixamento do Nivel de Fermi; o valor do "Urbach edge" também aumenta, indicando o aumento na densidade de defeitos no "gap". As propriedades originais do filme são recuperadas após recozimento do filme em torno de $150 \mathrm{C}$. Propriedades elétricas relacionadas ao transporte de portadores, e propriedades ópticas relacionadas à estrutura dos filmes foram medidas em três siluaçōes: antes da irradiação, após a irradiação, e após o recozimento.

\section{EFEITOS DA RADIAÇÄO DE ALTA ENERGIA EM InP E InGaAs RIBAS, P. R. F. IME-RJ/UFF.RJ BELLINI, J. V. IME-RJ \\ Souza, P. L.; Mendes, W. M. CETUC/PUC.RJ}

A determinação das propriedades dos compostos semicondutores sujeitos à radiação é relevante devido ao falo de tal exposição provocar mecanismos de degradaçāo, ao introduzir centros de recombinação não-radiativos, 
os gases nobres de modo que o perfil implantado fosse um plató na região de 1000 a partir da superficie. Utilizou-se reação nuclear para confirmar o perfil de profundidade do nitrogènio nas amostras pré e pós implantadas. Verificou-se por raio-X que a irradiação praticamente não modificava a amostra, porém por CEMS observou-se um espectro significativamente diferente ao não implantado, com um aumento do número de sítios com campos na regiāo de $200 \mathrm{liG}$, campos típicos de nitretos $\epsilon-\mathrm{Fe}_{2+x} \mathrm{~N}$. Verificou-se também que os nitretos formados após a implantação cram instáveis a $250^{\circ} \mathrm{C}$, após o que se reestruturavam em nitretos estáveis até temperaturas da ordem de $400^{\circ} \mathrm{C}$.

\section{Filmes Finos $(S U F)-09 / 06 / 94$}

\section{CINÉTICA DE FORMAÇÃO DOS NITRETOS DE FERRO EM Pós-DESCARGA}

Silva Sobrinilo, A. S. da; Drago, V.; Souza, $A$. R. vE

Universidade Federal de Santa Cutarina - UFSC

Camadas finas $(\sim 300 \mathrm{~nm})$ cle nitretos de ferro são forInadas sobre um substrato de aço SAE $1020(0.2 \% \mathrm{Wt}$ carbono) por nitretação em pós-descarga numa atmosfera de $\mathrm{N}_{2}+$ traços (entre 40 e $180 \mathrm{ppm}$ ) de $\mathrm{CH}_{4}$, sob pressão de 4 Torr em fluxo. Com o objetivo de estudar a cinética de formação destes nitretos variamos as tempcraturas de tratamento de $400 \mathrm{C}$ a 540 $\mathrm{C}$ e tempos de $15 \mathrm{~min}$. a $60 \mathrm{~min}$. As análises por espectroscopia Mössbauer (CEMS) inostram que a nitretação se inicia pela formação de aglomerados de fases metaestáveis identificadas como $\mathrm{FeN}$ e $F e_{1.6} \mathrm{~N}$ e que evoluem para a fase $\xi-\mathrm{Fe}_{2} \mathrm{~N}$ em temperaturas inferiores a $450 \mathrm{C}$. O espectro CEMS a temperatura ambiente da fase $\mathrm{FeN}$ apresenta apenas um singleto paramagnético com largura de linhas de apenas $0.24 \mathrm{~mm} / \mathrm{s}$ e deslocarnento isomérico $1 S=0.047 \mathrm{~mm} / \mathrm{s}$, o que corresponde a um ambiente de coordenação tetraédrica para o átomo de ferro. Ela possui uına estrutura cúbica tipo $Z$ nS com paràmetro de rede $a=4.33 \dot{A}$. Já a fase $F e_{1.6} \mathrm{~N}$ apresenta no espectro CEMS um dubleto paramagnético (QS $\sim 1.31 \mathrm{~mm} / \mathrm{s}$ e IS $=1.90 \mathrm{~mm} / \mathrm{s}$ ) de linhas muito alargadas, evidenciando vários ambientes de coordenação para o átomo de ferro. Não foi possível obte-la isoladamente e a sua estrutura não foi determinada. Tratamentos térmicos mostraram que ela representa um estágio intermediário na evolução da fase $\mathrm{FeN}$ para a fase $\xi-F e_{2} N$. Com resultados anteriormente realizados, conclui-se que a cinética de formação dos nitretos de ferro se dá através da evolução: FeN $\rightarrow F e_{1+x} N \rightarrow \xi-F e_{2} N \rightarrow \epsilon-F_{2-3} N \rightarrow \gamma^{\prime}-F e_{4} N$, onde $x<1$, e cada etapa é acompanhada por evolução de nitrogênio.

\section{OBTENÇĀO DE CARBETO DE SILÍCIO AMORFO HIDROGENADO A PARTIR DE DESCARGA LUMINESCENTE A $60 \mathrm{~Hz}$ Fragalli, J. F.}

Departamento de Física - Campus de Bauru - UNESP Nakagaito, A. N.; Misoguti, L.; Ramos, L. R.; BAgNaTo, V.S. IFQSQ, USP - Säo Carlos

Nós obtivemos filmes de carbeto de silicio amorfo hidrogenado $\left(\mathrm{a}-\mathrm{Si}_{1-x} \mathrm{C}_{x}: \mathrm{H}\right)$ com um reator de descarga luminescente tendo como gerador do plasma um transformador $0-3000 \mathrm{~V}$ a $60 \mathrm{~Hz}$. Usualmente um gerador de rádio-frequência (RF) a $13.56 \mathrm{MHz}$ é utilizado na obtenção de tais filmes. As condições nas quais estes filmes sāo preparados sāo: a) temperatura do substrato entre 150 e $200 \mathrm{C}$; b) pressão de deposição de 0.5 torr, com mistura de silana $\left(\mathrm{Sill}_{4}\right)$ e metano $\left(\mathrm{CH}_{4}\right)$ em diferentes pressōes parciais; $c$ ) tensão no transformador de $450 \mathrm{~V}$ e corrente no plasma de $3 \mathrm{~mA}$, indicando uma potència de $1.35 \mathrm{~W}$. Resultados preliminares indicam que filmes de a-Si $i_{1-x} \mathrm{C}_{x}: I 1$ com baixo teor de carbono apresentam significante foto-sensibilidade, e à medida que mais carbono é incorporado mais resistivo torna-se o filme.

\section{RECRISTALIZAÇÄO DE FILMES DE SILICIO AMORFO HIDROGENADO INDUZIDA POR LASER DE ARGÓNIO ramos, L. R.; Misoguti, L.; Nakagaito, A. N.; Bagnato, V. S. IFQSQ, USP - São Carlos Fragalli, J.F. \\ Departamento de Física - Campus de Bauru - UNESP}

Filmes de silicio amorfo hidrogenado (a-Si:H) preparados por descarga luminescente a $60 \mathrm{~Hz}$ foram irradiados com laser de argónio (cw $A r^{+}$laser) de alta intensidade. Duas regiões distintas são observadas no filme ao longo do raio do feixe incidente. No centro o filme apresentase quase transparente indicando um processo de recristalização acelerado. Em regiōes periféricas o filme apresenta uma alteração em sua cor: inicialmente vermelho, após a incidência do laser o filme torna-se amarelo. A transição entre estas duas regiões é abrupta. A formação destas duas regiōes está associada ao caráter gaussiano do feixe. A recristalização é fortemente dependente da temperatura local, que por sua vez é mais intensa no centro do feixe laser, onde sua intensidade $\dot{e}$ maior. Figuras de microscopia eletrônica de varredura (SEM) são mostradas, e medidas da transmiância do filme em cada região são realizadas. 